\title{
المنافسة غير المشروعة \\ في ضوء القانون القطري
}

د. محمد بن عبدالعزيز الخليفي

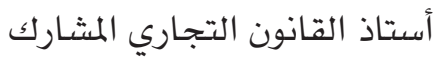

كلية القانون - جامعة قطر

\author{
د. ــلاح زين الدين \\ أستاذ القانون التجاري المشارك التهن \\ كلية القانون - جامعة قطر التوان المتاري
}

المخص:

يتناول هذا البحث دراسـة القواعد القانونية الناظمة للمنافسـة غير المشروعة في ضوء المواد من68 إلى73 من قانون التجارة القطري 27 لسنة 2006 وغيرها من المواد

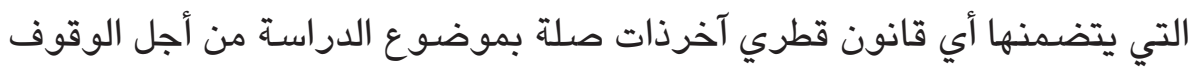
على مدى فاعلية تلك المواد في تحديد ممارسـات المنافسـة غير المشروعة وكفي وكفايتها في

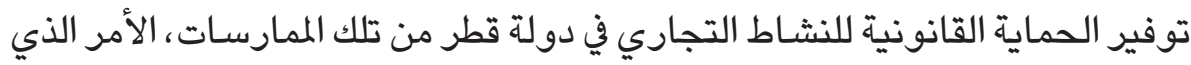
اقتضى أن نقسم هذه الدراسة إلى المباحث الآتية:

المبحث الأول - ماهية المنافسة غير المشروعة.

المبحث الثاني - هـور المنافسـة غير المشروعة.

المبحث الثالث - دعوى المنافسة غير المشروعة.

وقد خلصت هذه الدراسـة إلى عدد من النتائج والتوصيات، تم رصدها في الخاتمة،

نأمل أن يخذها المشرع القطري في الحسبان.

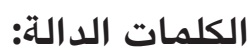

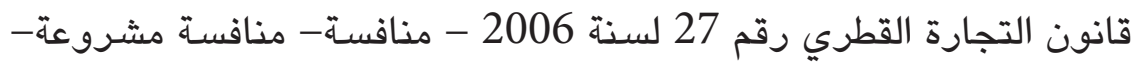

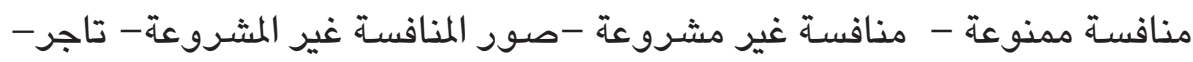

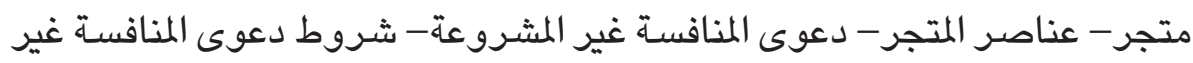
المشروعة- الخطأ - الضرر - العلاقة السبيية. 
يشكل النظام الاقتصادي(1)عصب الحياة في الدولة الواحدة، والجسر المتين الذي

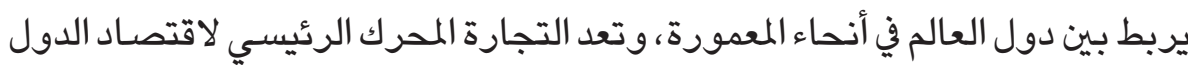

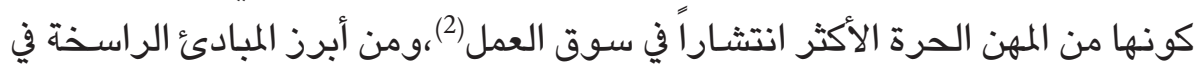

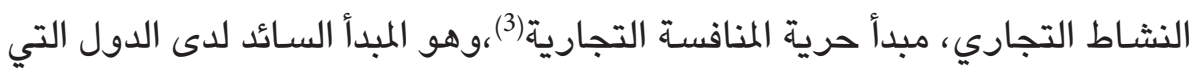
تتبع النظام الرأسمالي (4).

ومن المعلوم أن دولة قطر تَعتمد النظام الرأسمالي (الاقتصاد الحر) منهجاً

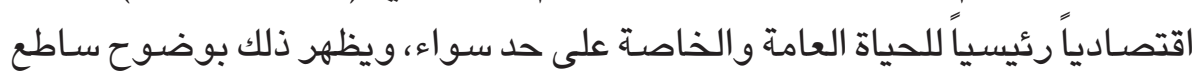

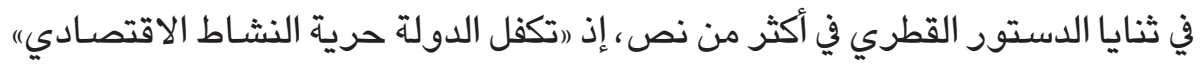

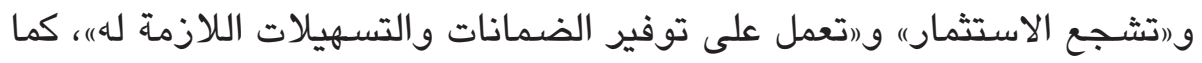

(1) يُعرف الاقتصادي السويدي Assar Lindbeck ) رالنظام الاقتصادي" بأنه "عبارة عن مجموعة من آليات

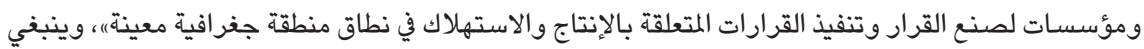

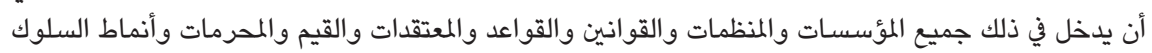

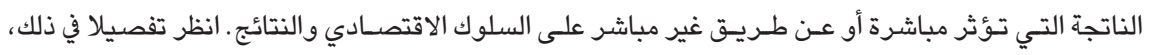

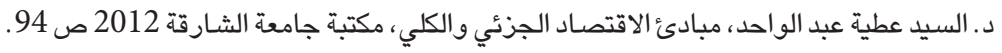

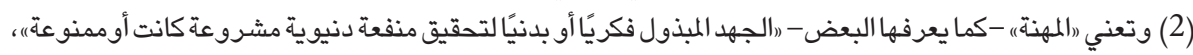

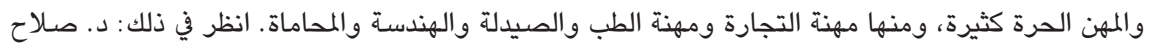

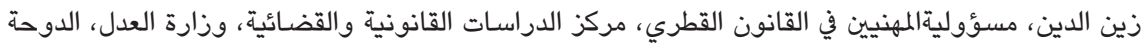

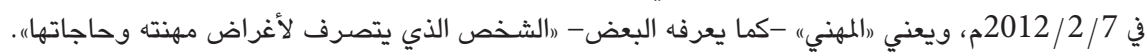

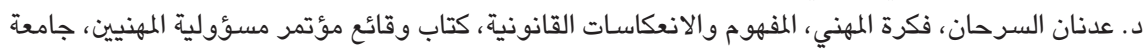

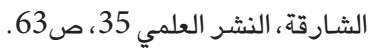
وقد ظهر هذا المبدأ (FreeCompetition)بجلاء بموجب قانون

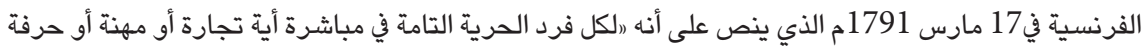

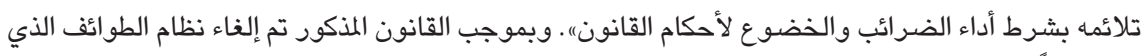

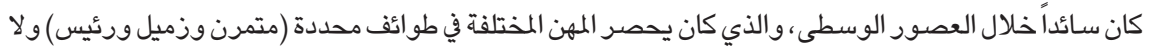

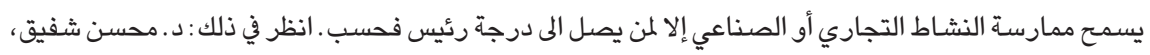

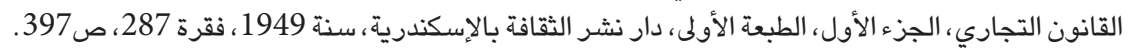

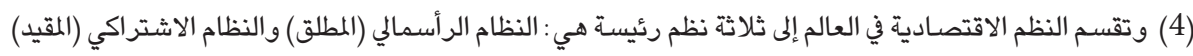

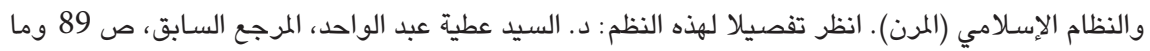

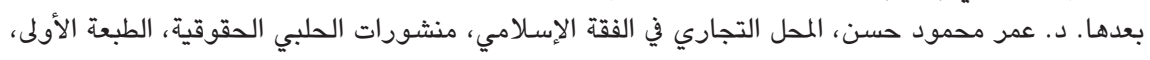

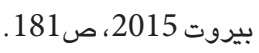


تصون (الملكية الفردية للدوله)، و(الملكية الخاصة للأفراد) سواء بسواء(1)، الأمر الذي أسس بقوة لكي تصبح دولة قطر من الدول الرائدة في فنون الاستثمار عبر الدول،

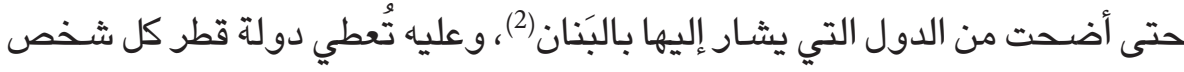

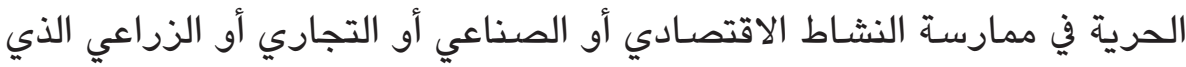

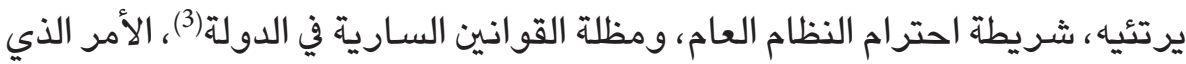
يقتضي تنظيم المنافسة في السوق التجارية، لكي يقطف كل مجتهـ ثمرة اجتهاده،

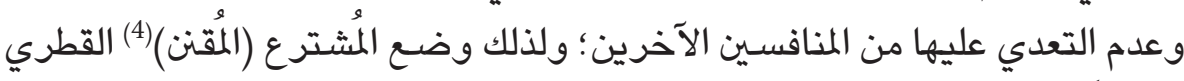

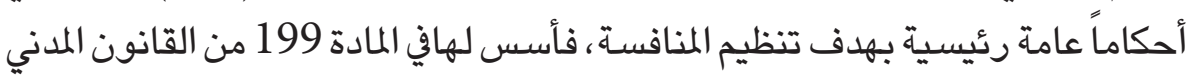

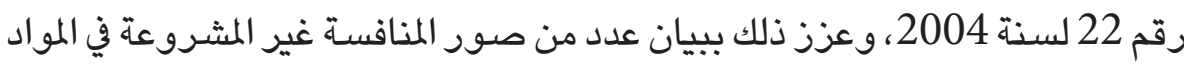

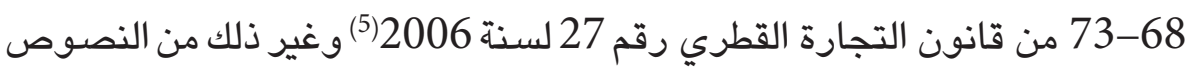
القانونية -ذات الصلة- في القوانين القطرية الأخرى (6).

وليس من شك أن المنافسة -بالمُطلق - تُعد من الطبائع الغريزية للبشر في مجالات

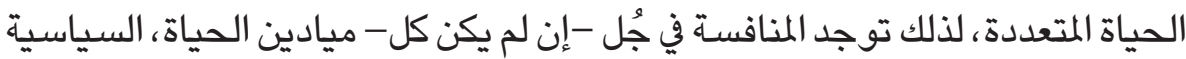

(1) المواد 26 و27 و 28 و 31 من من الدستور القطري. (2) وخير مثال على ذلك صفقة شراء شركة (قطر القابضة)، متجر (هارودز)، الذي يعد من أهم أيقونات بريطانيا التجارية في وسط لندن. (3) ذلك أن تطبيق القوانين وتطويرها محل اهتمام القيادة القطرية على الدوام. انظر في ذلك : د. محمد عبد العزيز

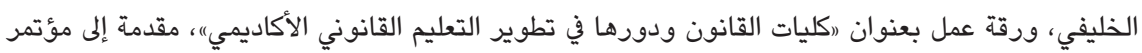

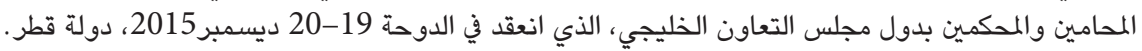

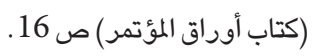

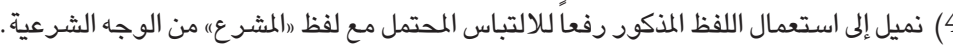
وسوف نعرض هذه المواد في ثنايا هذه الدراسة.

(6) ومن قبيل ذلك، قانون تنظيم مهن الصيدلة والوسطاء ووكلاء مصانع وشركات الأدوية القطري رقم 3 لسنة

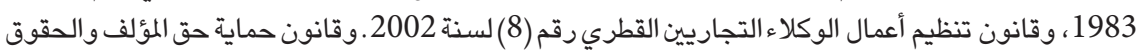

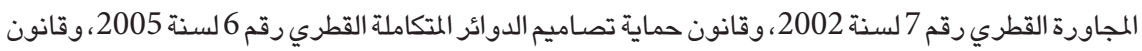

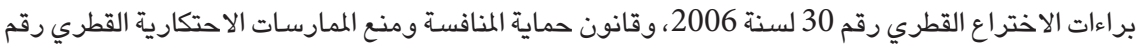

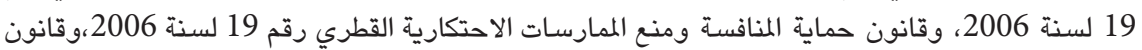
تنظيم ومراقبة وضـع الإعلانات القطري رقم (1) لسنة 2006. 
والاجتماعية والفنية والرياضية والاقتصادية والتجارية(1). ويقتضي منطق العدل

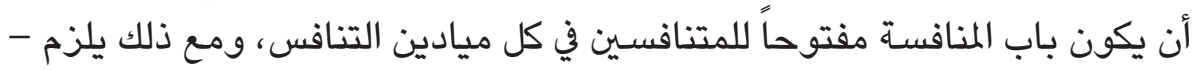

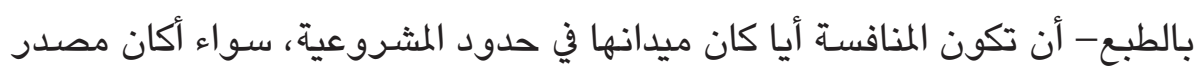

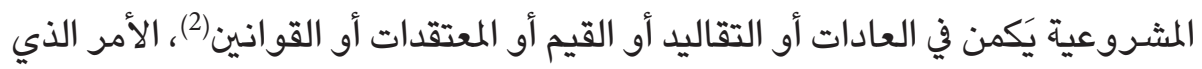

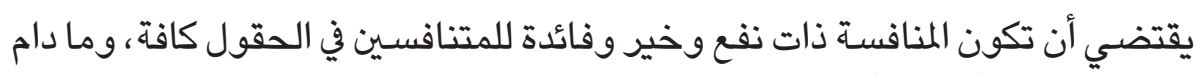

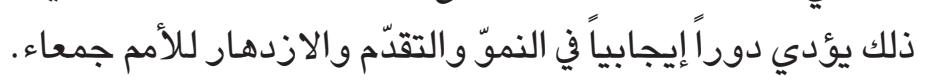

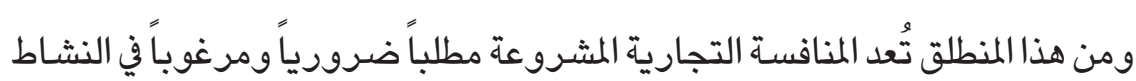

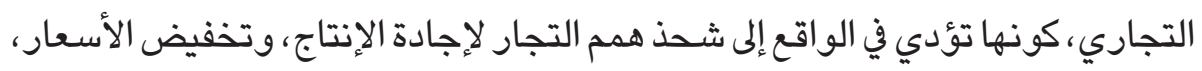
ونيل رضى الزبائن، مما يؤدي إلى تحفيز حقيقي للتجارة في المجتمع، ويسهـم بفاعلية

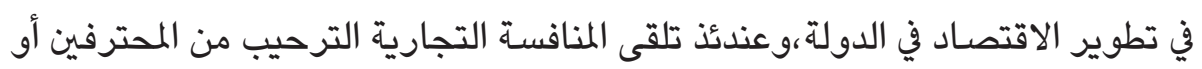

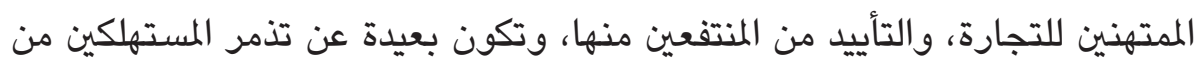

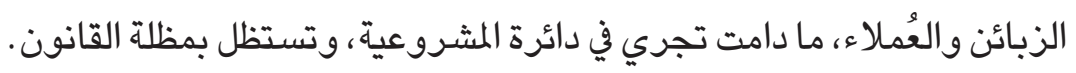
وتؤدي المنافسة التجارية المشروعة وظيفة مزدوجة في آن واحد، فمن جهة،

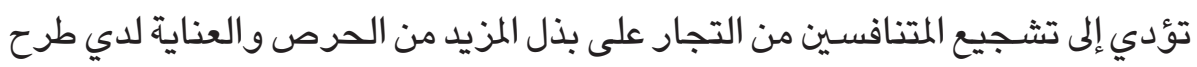

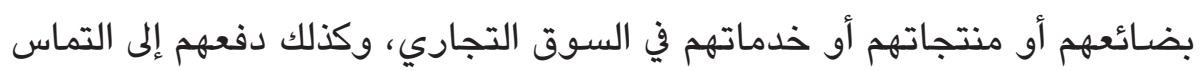

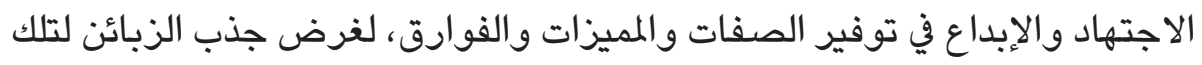

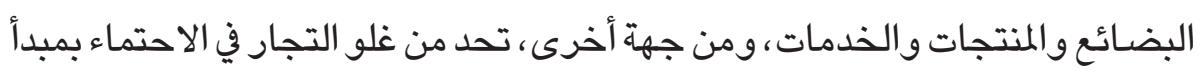

(1) ويعني لفظ „المنافسة، في الاصطلاح اللغوي، وجود عدد من الأشخاص يسعون أو يتزاحمون على الاستيثثار

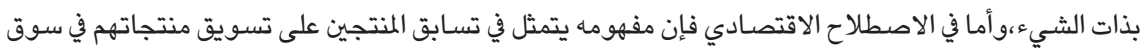

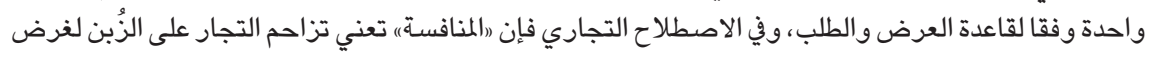

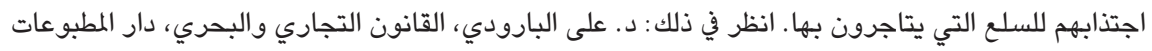

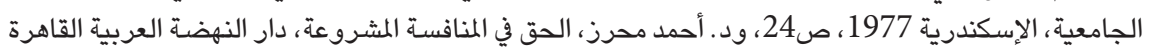

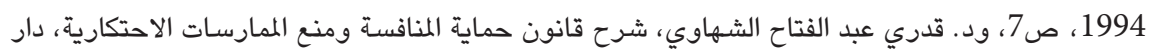

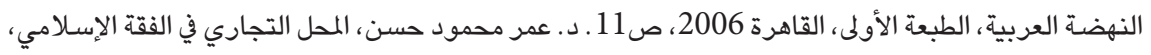

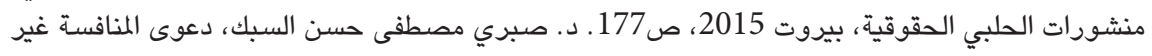

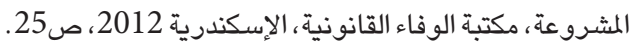

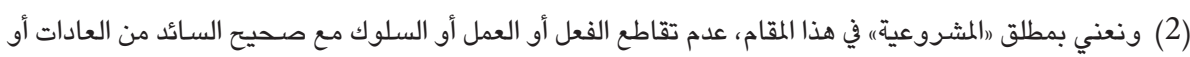

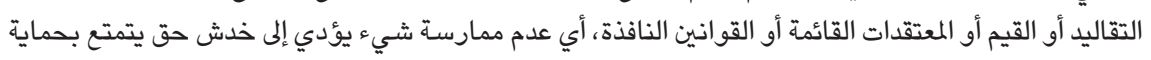
مشروعة أيا كان مصدر شرعية ذلك الحق. 
حرية التجارة، وذلك من خلال محاربةالممارسات التي تؤدي إلى إخراج الأفعال أو

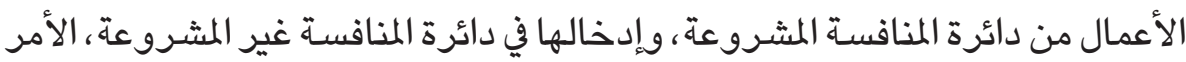

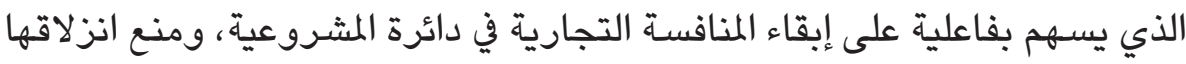

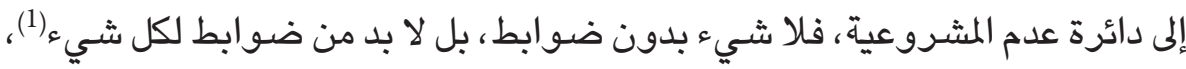

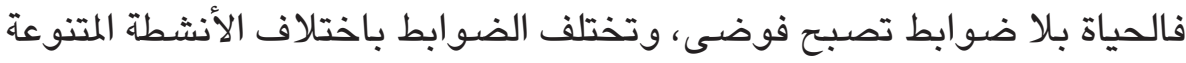
والمهن المتعددة التي تمارس في المجتمع الواحد، وقد يصعب ونس حصر الأنشطة والمهن لأنها في تطور متجدد ومستمر .

لذلك فإن حرية المنافسة في النشاط التجاري -كما باقي المهن الأخرى- ليست

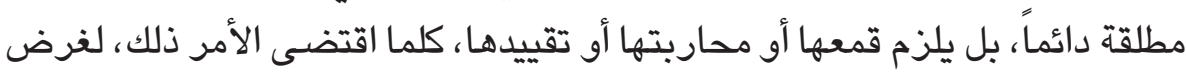

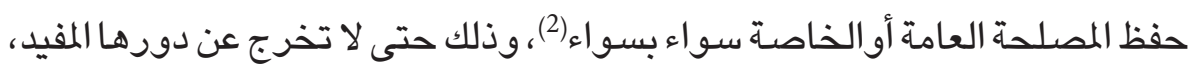

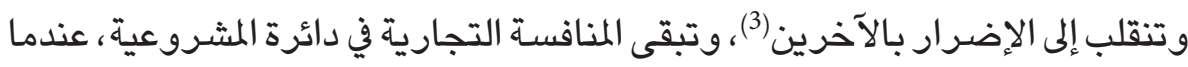

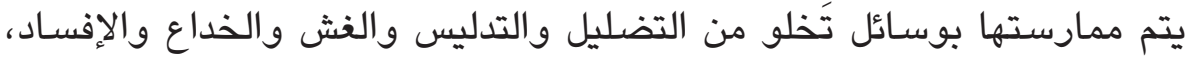

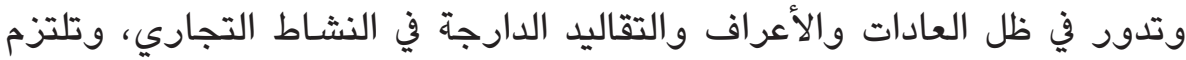
بالقواعد أو الأنظمة القانونية الحاكمة للنشاط التجاري، وتجري والجرات تحت سقف مظلة

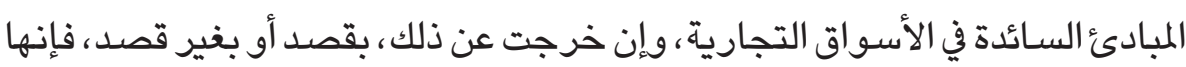

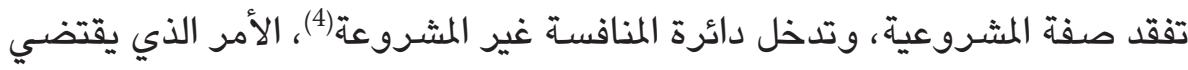

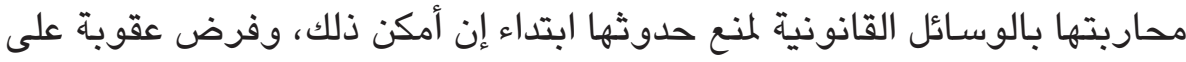

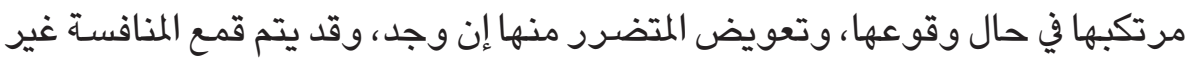

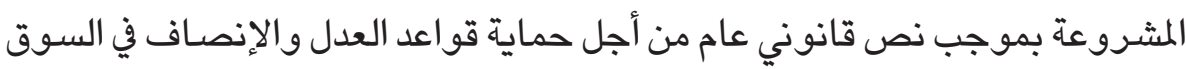
التجارية،، لدى وجود ممارسات منافسة غير مشروعة ب(5)، أو بموجب نص نص قانوني (1) وقد قال نبي البشرية جمعاء، سيدنا محمد -صلى الله عليه وسلم- عن رسالته السماوية السمحة : (إنما بعثت لأتمم

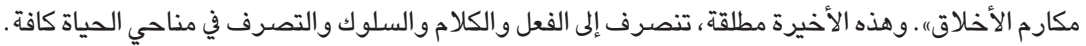

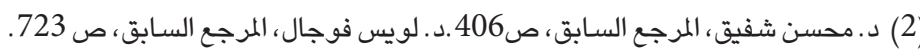

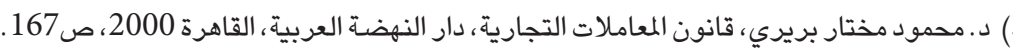

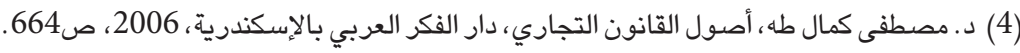

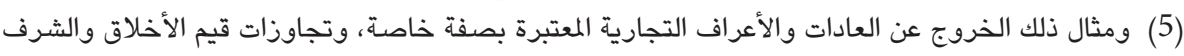

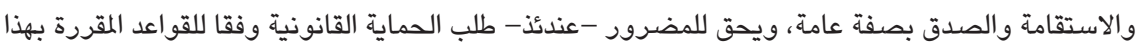


خاص من أجل حماية حقوق خاصة لدى وجود اعتداء عليها(1)، أو بموجب شرط

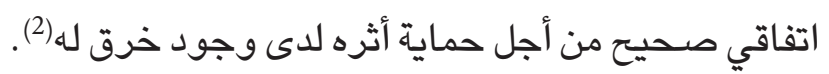

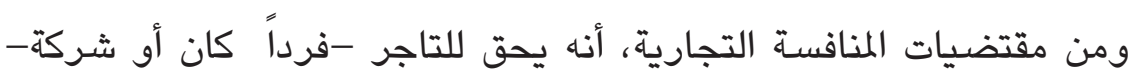

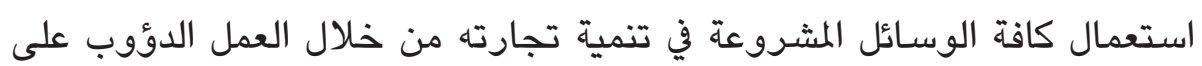

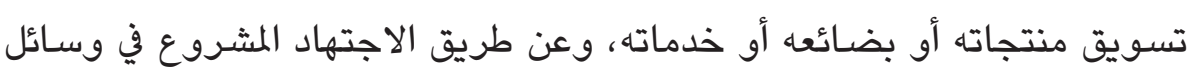

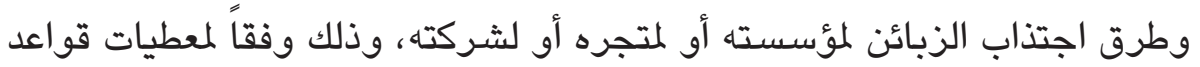

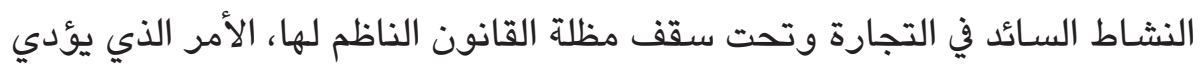

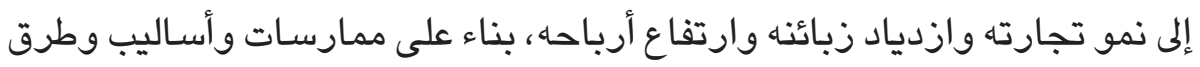

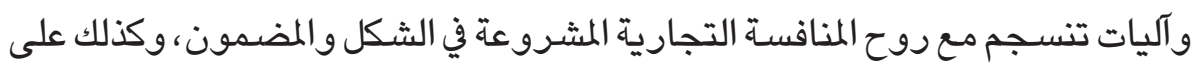
مستوى الوسيلة والغاية(3)،وذلك ما ينبغي أن يكون دأب أرباب الأنشطة التجارية

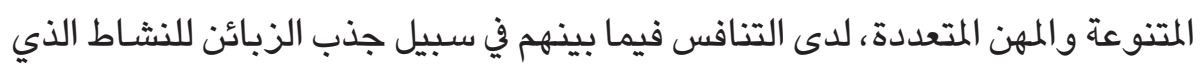

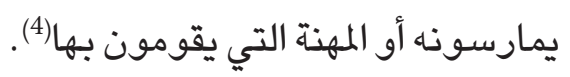

ويُثار التساؤل -بقوة- بشأن حدود المنافسة التجاريةوحول مشروعية الوسيلة التي تستخدم في سبيل ذلك، وتقدير أخلاقية الغاية التي تهدف إلى تحقيقها، ونطاق

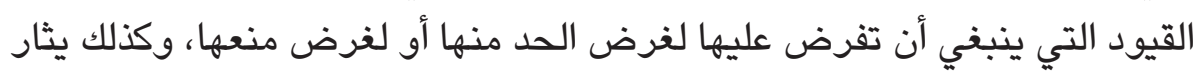

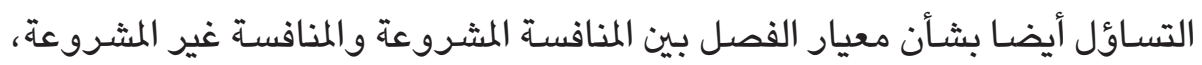
وصور هذه الأخيرة، والدعوى التي تحمي المتضرر من ذلك؟ والجزاءات التي يمكن

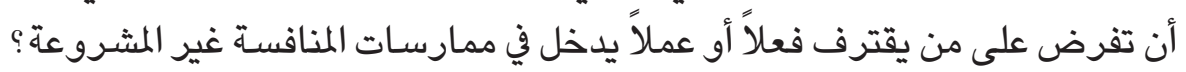

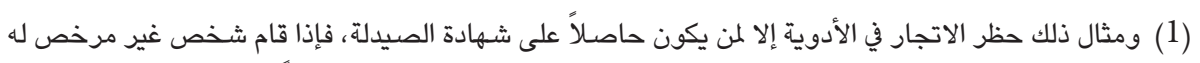

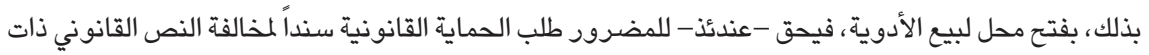

الصلة.

(2) ومثال ذلك وجود شرط في عقد بيع المتجر يحظر على البائع فتح متجر مماثل، فيحق للمضرور-عندئذ- طلب

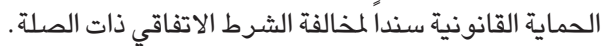

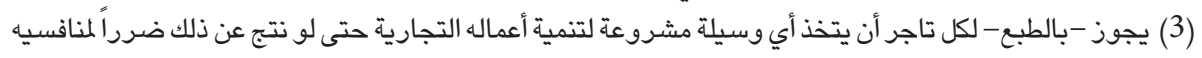

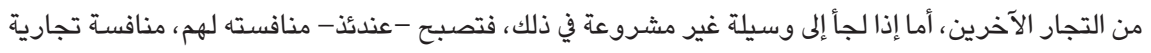

$$
\text { غير مشروعة. }
$$

(4) وتتمثل المهن بصورة عامة "افي تكريس النشاط بطريقة رئيسية ومعتادة لإنجاز مهمة معينة بهدف تحقيق ربح

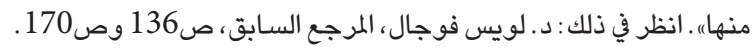


ونحاول في هذه الدراسـة، الإجابة على هذه التسـاؤلات، ما استطعنا إلى ذلك

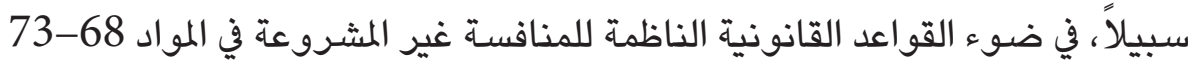

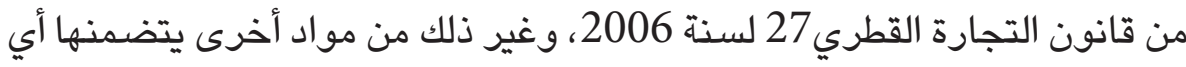

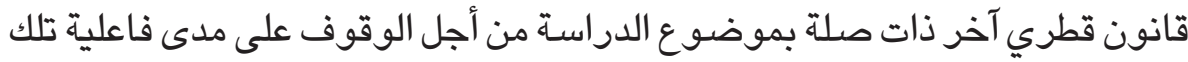

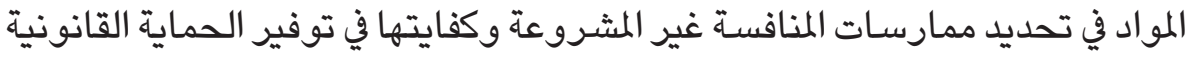
للنشـاط التجاري من تلك الممارسات، الأمر الذي اقتضى أن نقسـم هذه الدراسـة إلى فيلى

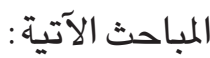

المبحث الأول - ماهية المنافسـة غير المثروعة. المبحث الثاني - صور المنافسة غير المشروعة. المبحث الثالث - دعوى المنافسة غير المشروعة. 


\section{المحث الأول \\ ماهية المنافسة غير المثبروعة}

نتناول في هذا المبحث، بيان ماهية المنافسة غير المشروعة ومعيارها وتمييزها عن

المنافسـة الممنوعة، في مطلبين اثنين على التوالي.

المطلب الأول

\section{تعريف المنافسة غير المشروعة وتحديد معيارها}

نحاول في هذا المطلب الوقوف على تعريف المنافسـة غير المشروعة، ثم نعرض للمعيار

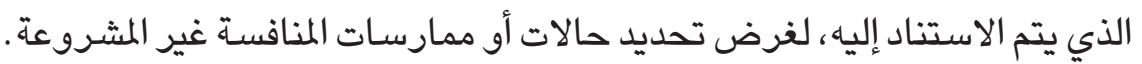

\section{الفرع الأول}

\section{تعريف المنافسة غير المثسروعة}

نستعرض في هذا الفرع تعريف المنافسـة غير المشروعة في الفقه والقانون والقضـاء

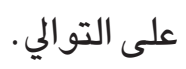

أولاً - تعريف المنافسة غير المشروعة في الفقه:

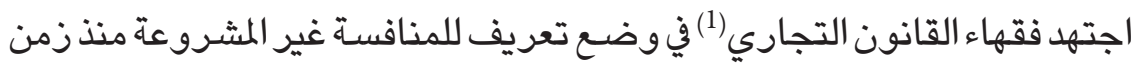

بعيد، فقد أورد لها الفقه القانوني الفرنسي عدة تعاريف (2)،ولعل أبرز تلك التعاريف

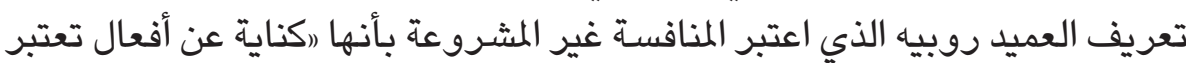

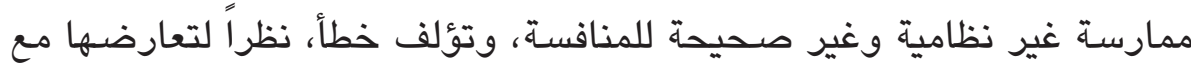

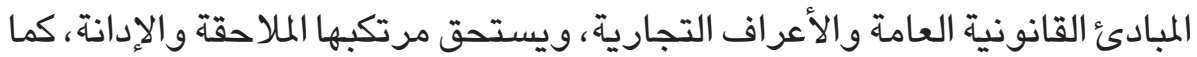

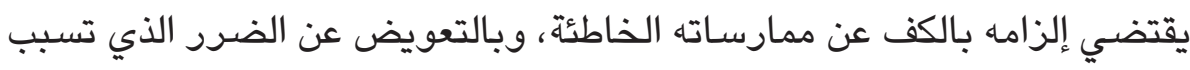

(1) نميل إلى استخدام تعبير (فقهاء القانون) لغرض عدم الالتباس مع تعبير (فقهاء الشريعة الإسلامية)، الغراء.

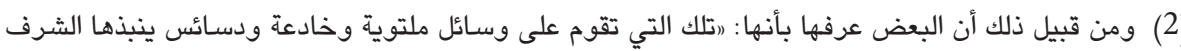

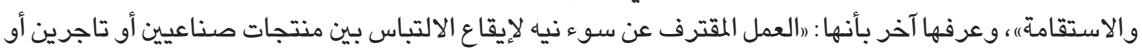

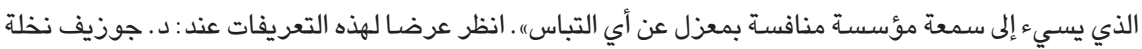

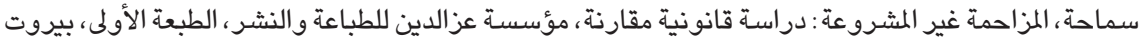

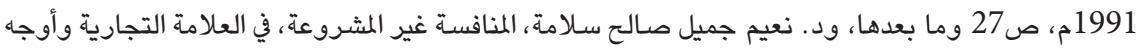

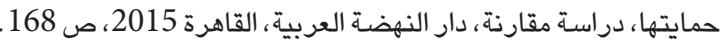




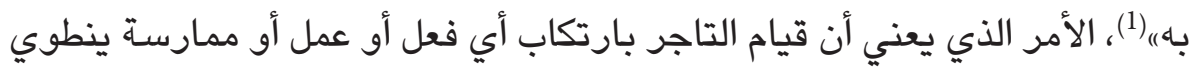

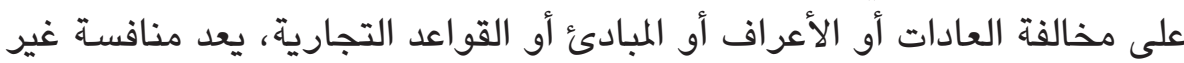

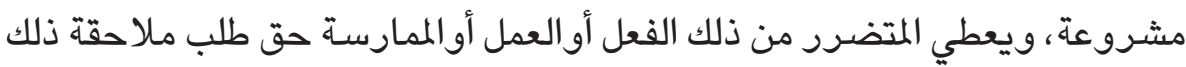
التاجرومحاسبته عما اقترف من مخالفات بهذا الصدد (2).

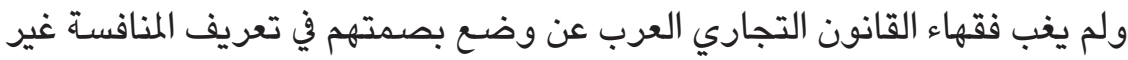

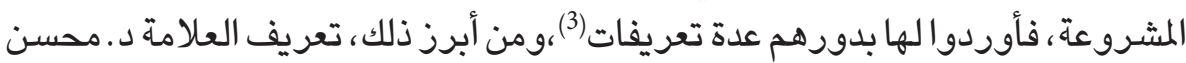

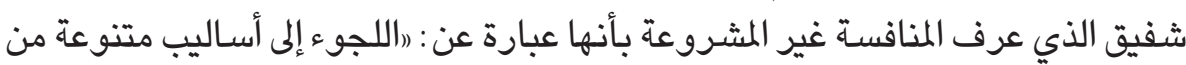

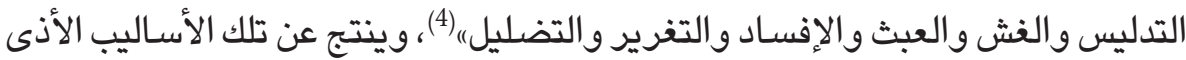
والضرر للتجار المنافسـين والأشخاص المستهلكين والسـوق التجارية (5). ويبدو أنه يوجد قواسم مشتركة تجمع التعريفات التي أطلقها فقهاء القانون التجاري

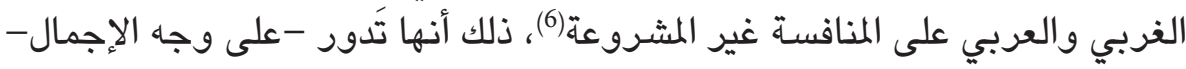

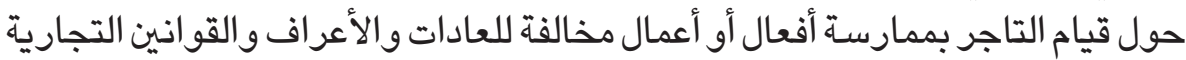

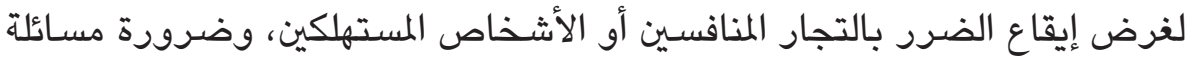

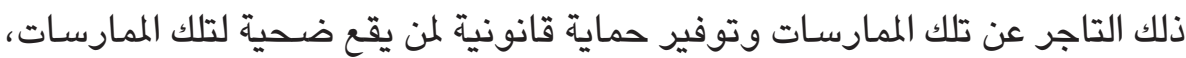

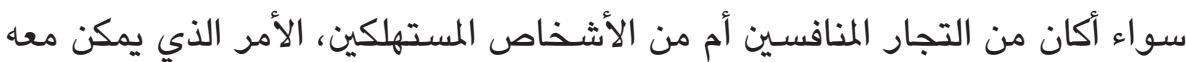

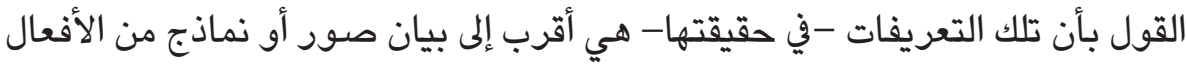

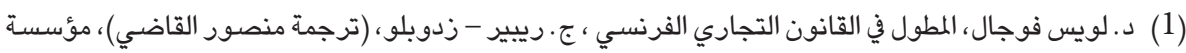

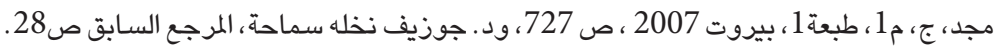

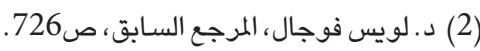

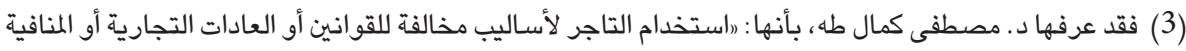

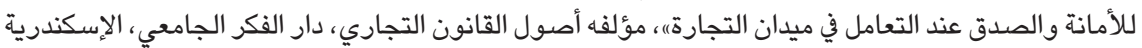

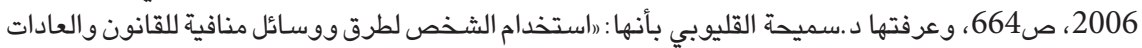

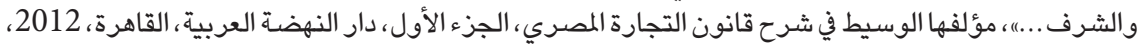

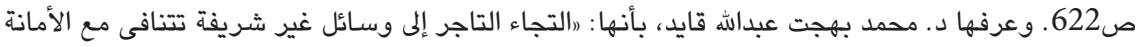

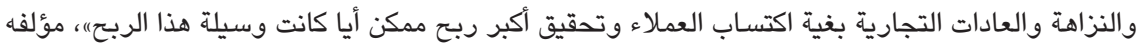

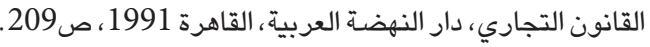

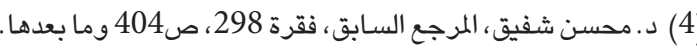

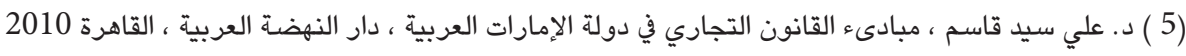

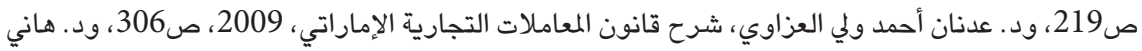

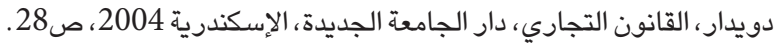

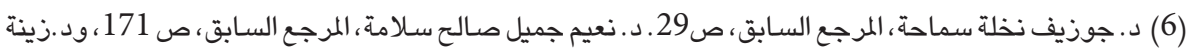

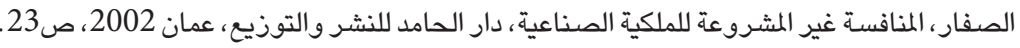


أو الأعمال التي تعد من المنافسـة غير المشروعة أكثر من اعتبارها تعريفاً لهذه الأخيرة،

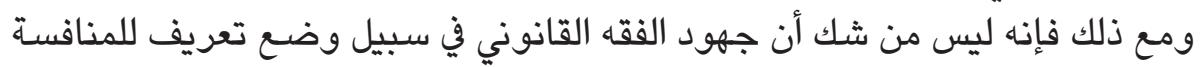

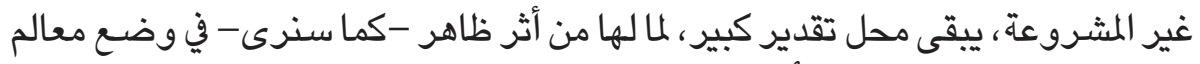

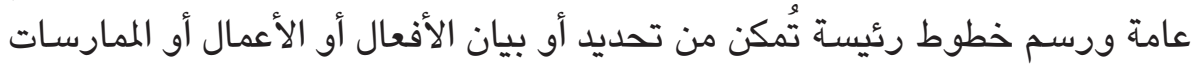
التي تدخل في دائرة المنافسة غير المشروعة، ومن ون ثمن يمكن البناء فوقها والقياس عليها.

\section{ثانياً - تعريف المنافسة غير المثروعة في القانون:}

يبدو أن سعي الفقه القانوني نحو وضع تعريف للمنافسة التجارية غير المشروعة

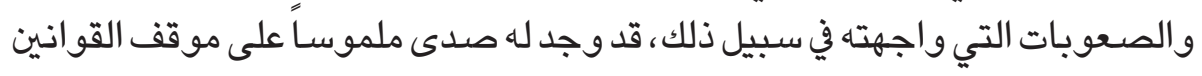
من ذات المسألة، الأمر الذي جعلها أمام خيارين رئيسيين، هما:

الخيار الأول: الإحجام عن إعطاء تعريف للمنافسـة التجارية غير المشروعة،

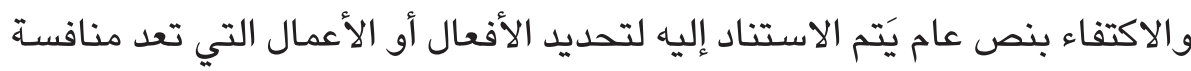

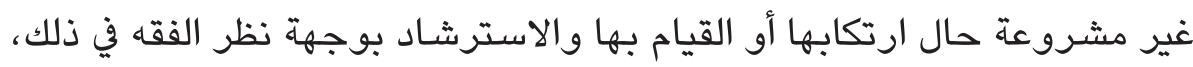

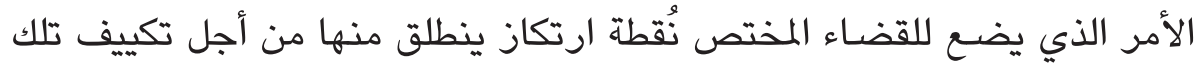

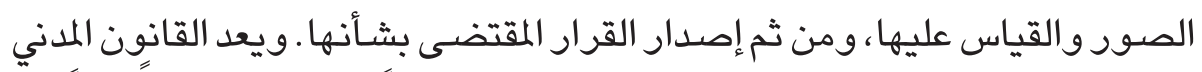

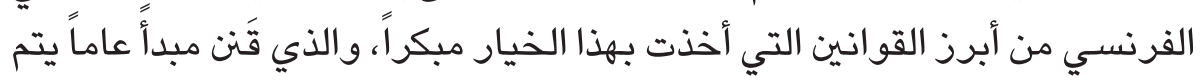

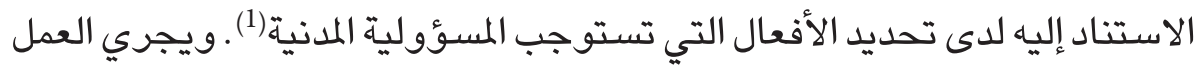

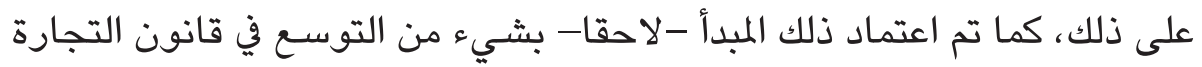

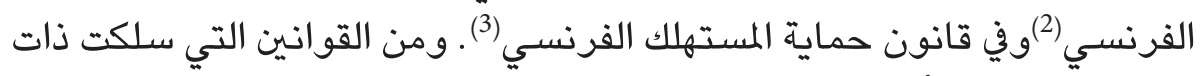

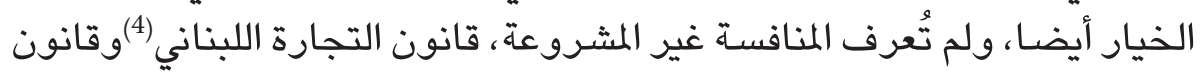

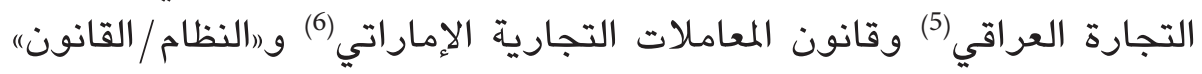

(1) المادتان 1382 و1383 من القانون المذكور . انظر تفصيلا في ذلك: د. لويس فوجال، المرجع السابق، ص723.

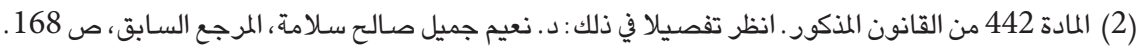

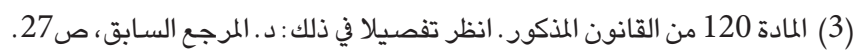

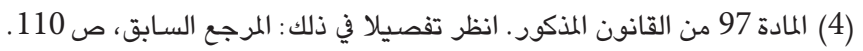

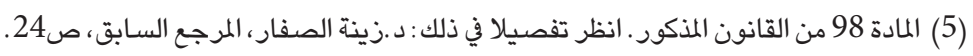

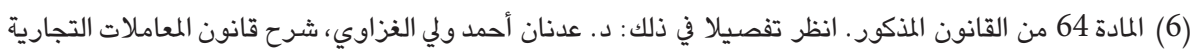

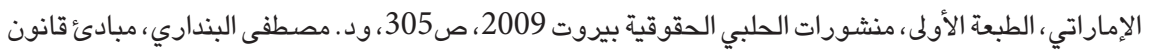

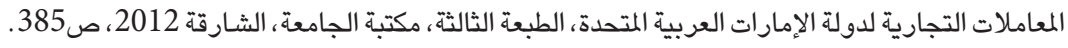


التجاري السعودي(1)، وكذلك فَعَلَ اتفاق الجوانب المتصلة بالتجارة من حقوق

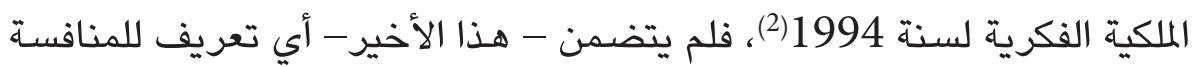

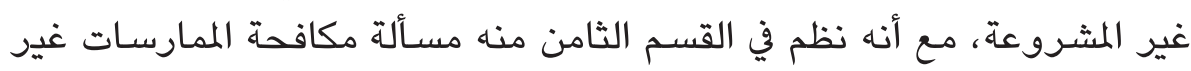

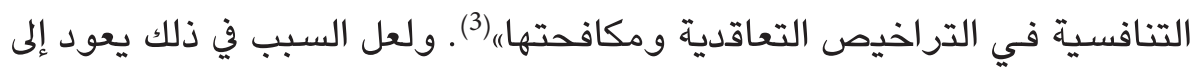

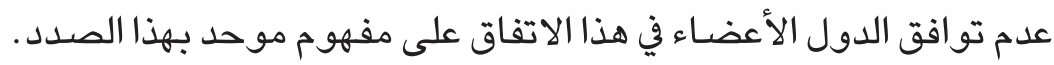

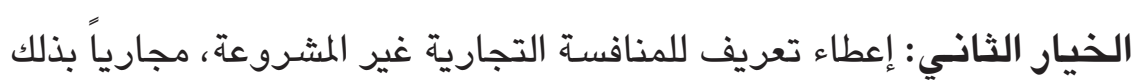

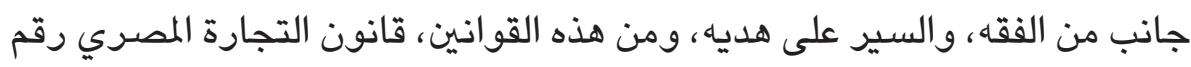

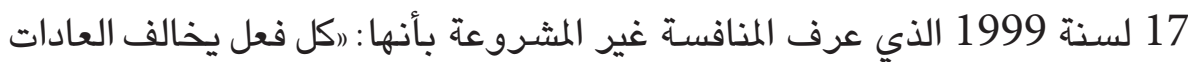

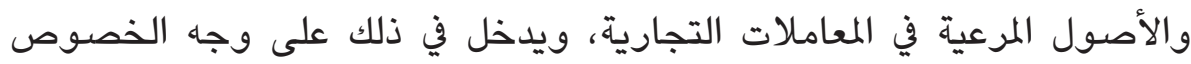

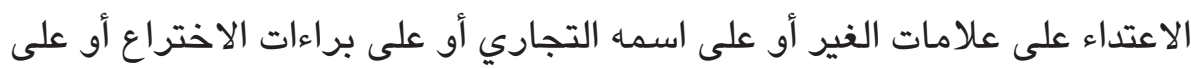

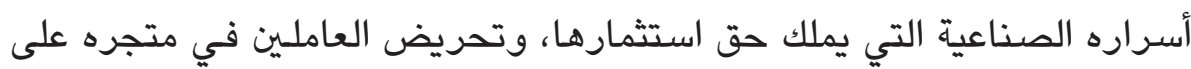

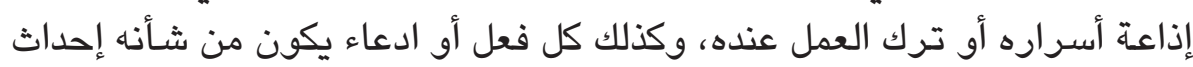

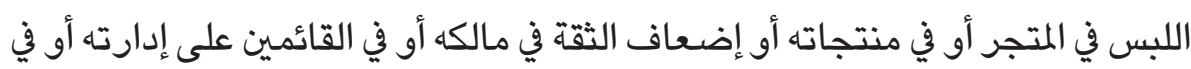

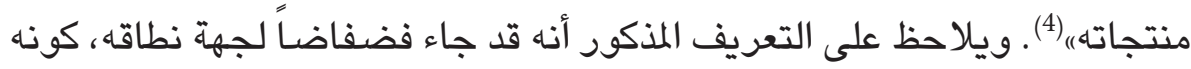

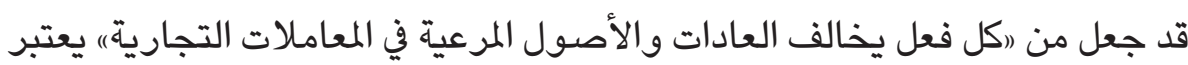

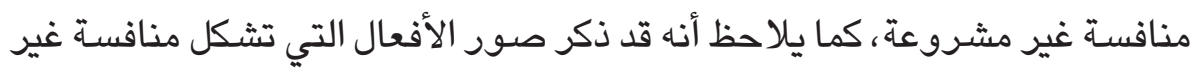
مشروعة على سبيل المثال وليس على سبيل الحصر ، الأمر الذي يعني أن بالِ باب الأفعال

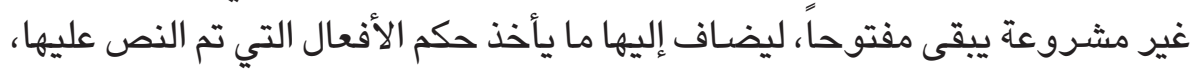
وينسجم ذلك مع واقع التطور المستمر في النشاط التجاري.

ويُعرف قانون المنافسة غير المشروعة والأسرار التجارية الأردني رقم 15

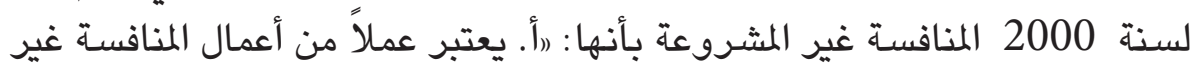

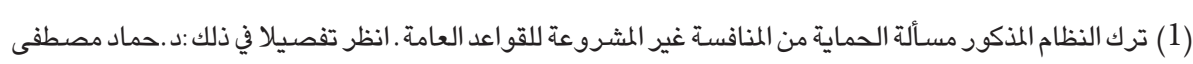

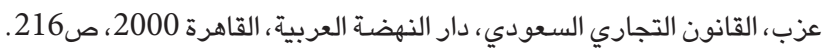

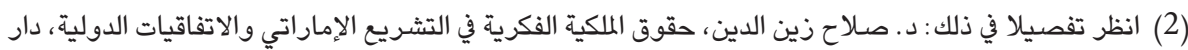

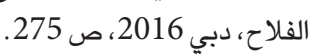

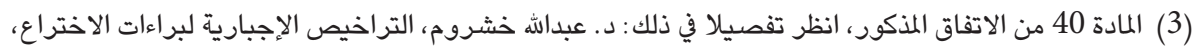

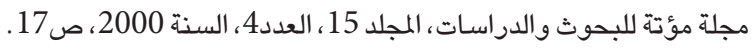

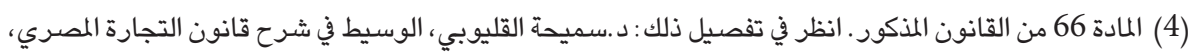

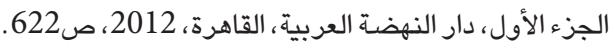


المشروعة كل منافسـة تتعارض مع الممارسات الشريفة في الشؤون الصناعية أوٍ

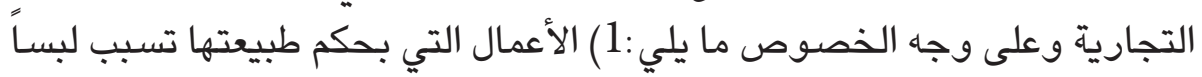

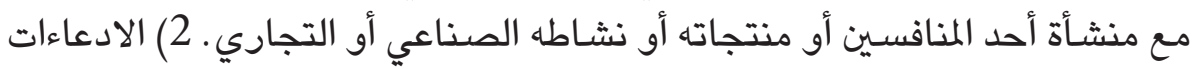

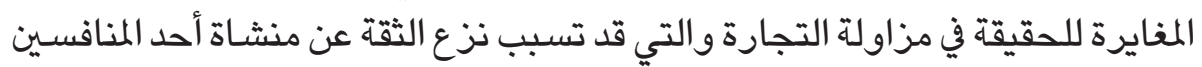

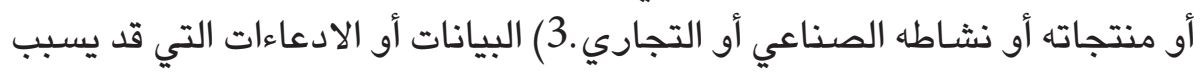

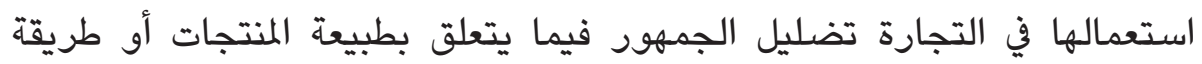

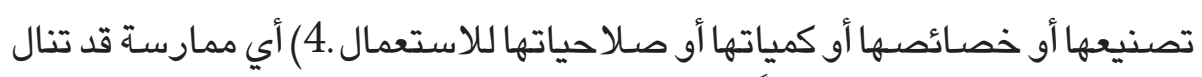

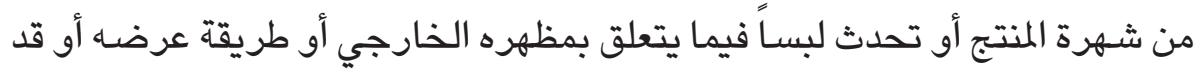

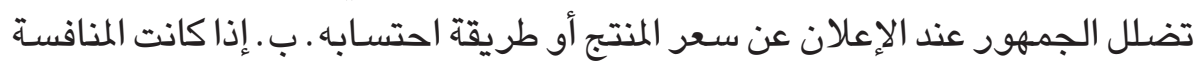

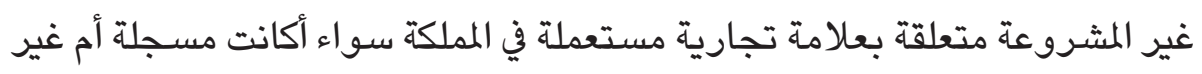

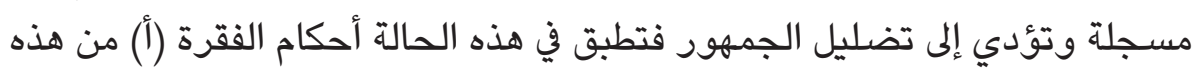
المادة . ج. تسري الأحكام الواردة في الفقرتين (أ) و (ب) من هذه هذه المادة الفي على الخدمات

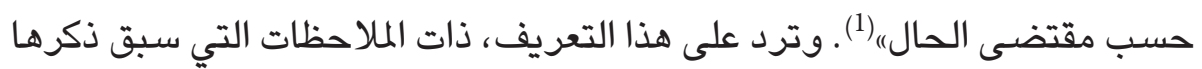

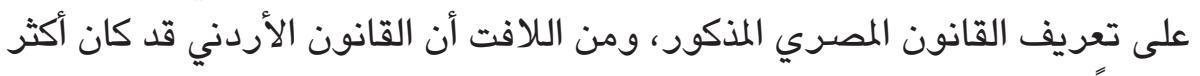

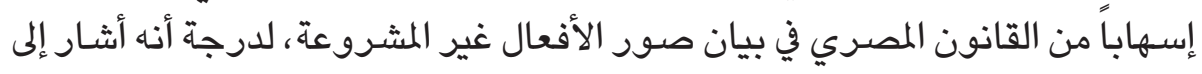

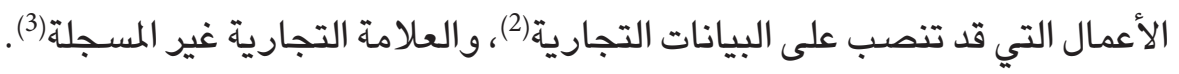

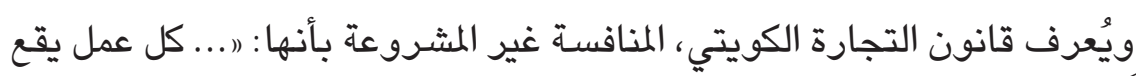

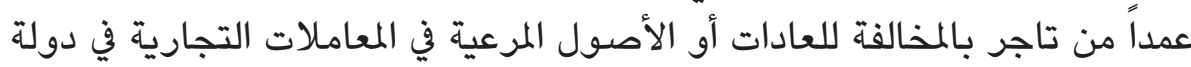

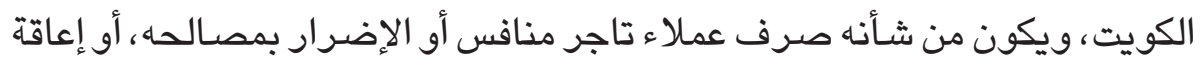

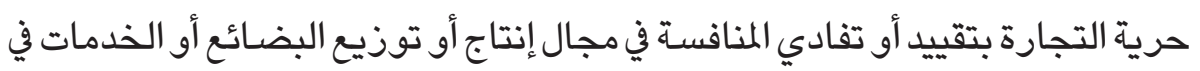

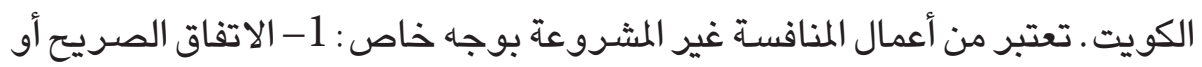

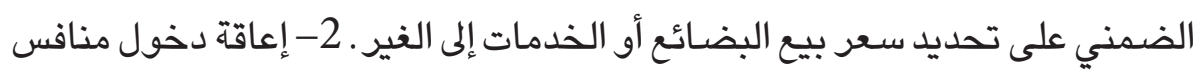
(1) المادة 2 من القانون المذكور . انظر تفصيلا في ذلك : أحمد على الخصاونة، الأحكام القانونية للمنافسة غير المشروعة

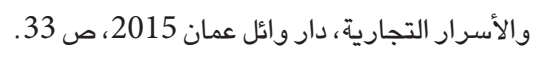

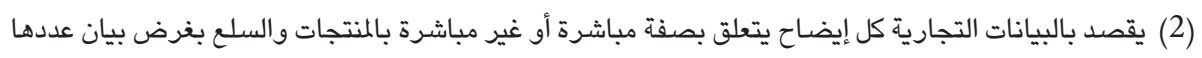

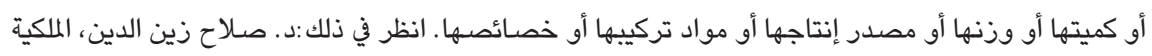

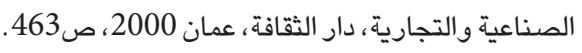

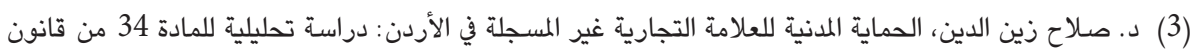

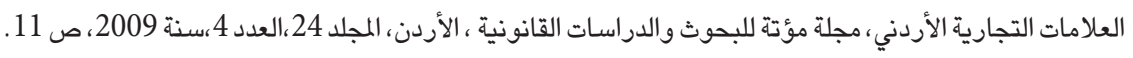


في السوق بغير سبب مشروع. 3- الإسـاءة إلى سمعة تاجر آخر أو الحط من قيمة

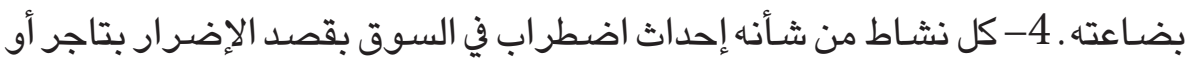
تجار آخرين)|(1)، وقد تم إدخال هذا التعريف بموجب تعديل جرى إحى على القانون المذكور

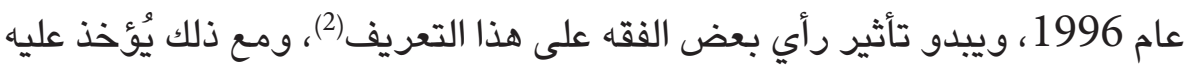

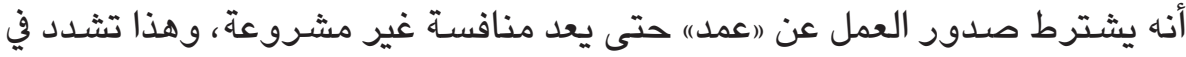

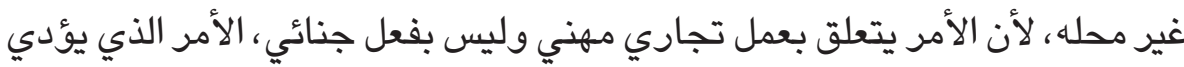

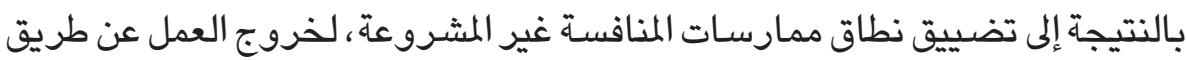

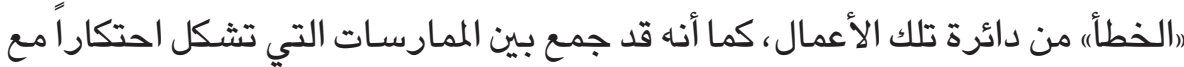

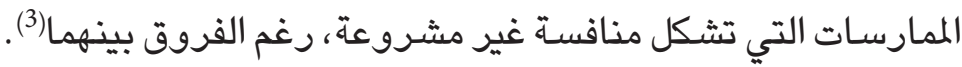

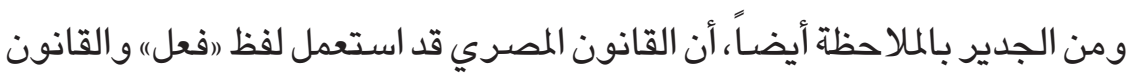

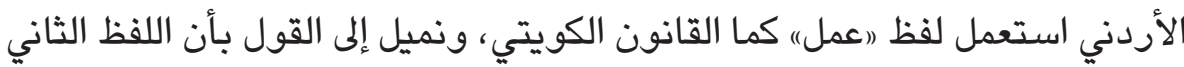

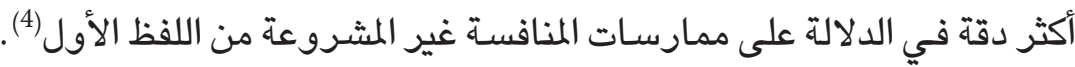
وقد كان للمنافسـة غير المشروعة نصيب من الاهتمام المبكر في التشريع الدولي(5)،

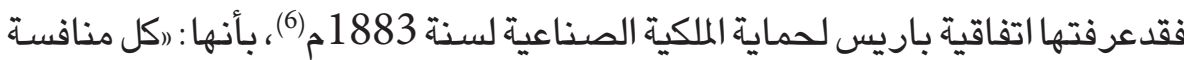

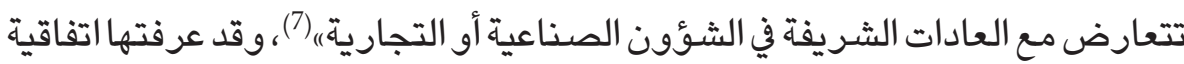

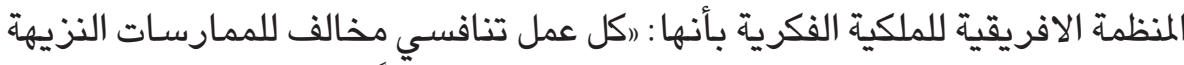

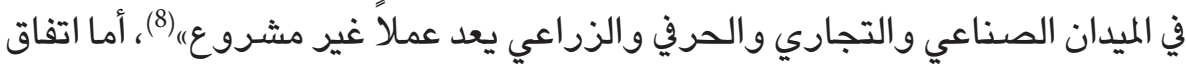

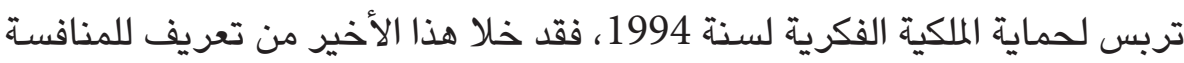
التجارية غير المشروعة، كما سبقت الإشـارة.

(1) المادة 60 (مكرر أ) من قانون التجارة الكويتي (رقم 68 لسنة 1980( المعدل بالقانون رقم 13 لسنة 1996.

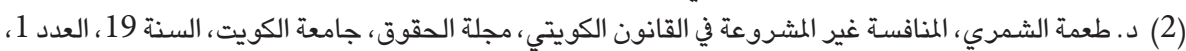
مارس

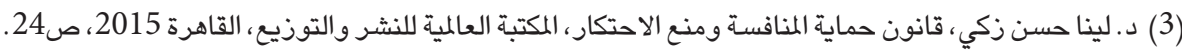

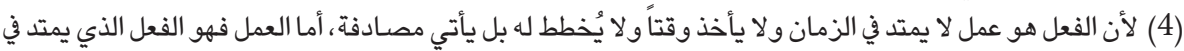

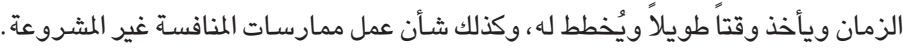

(5) Dr. Mohamed Salem Abou El Farag, Intellectual Property Law, second edition,

Dar Al Nahda Al Arabia, Cairo, 2009. p. 127.

(6) د. صـلاح زين الدين، حقوق الملكية الفكرية في التشريع الإماراتي والاتفاقيات الدولية، دار الفلاح ، دبي 2016، ص . 257. (7) المادة 10 ثانياً من الاتفاقية المذكورة. (8) (المادة 17 من الاتفاقية المذكورة. 
ونلاحظ أن صدى تعريف المنافسة غير المشروعة في التشريع الدولي قد تردد

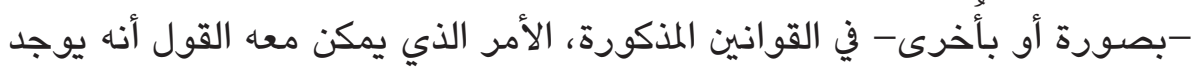

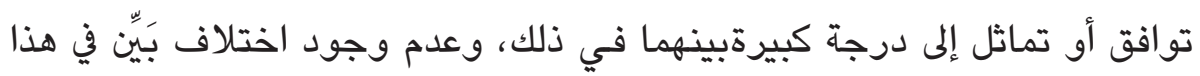

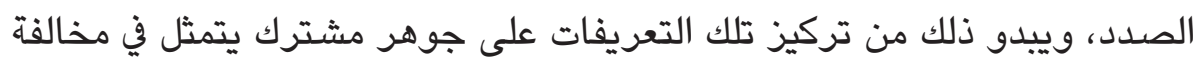

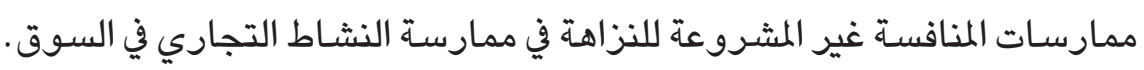

\section{موقف القانون القطري من الخيارين المذكورين:}

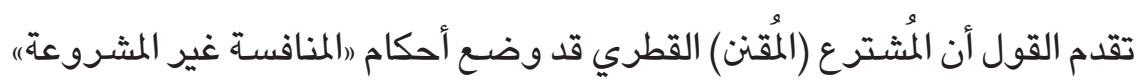

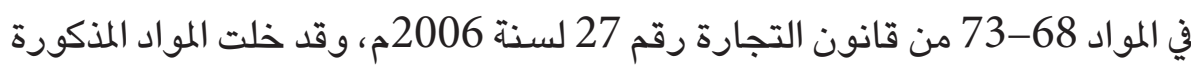

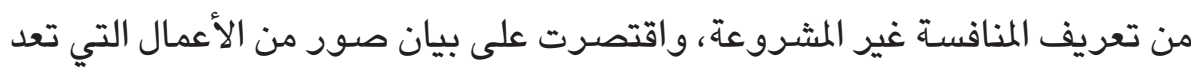

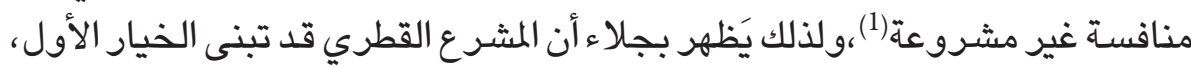

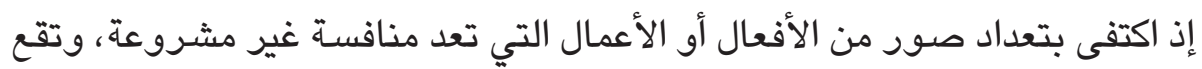

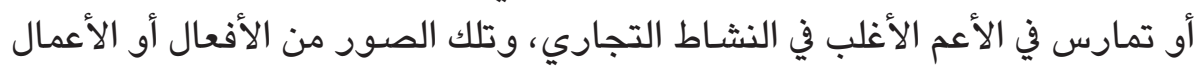

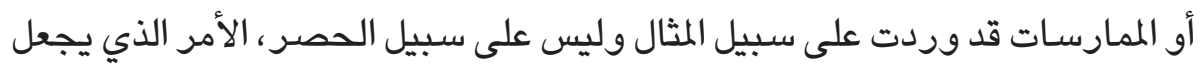

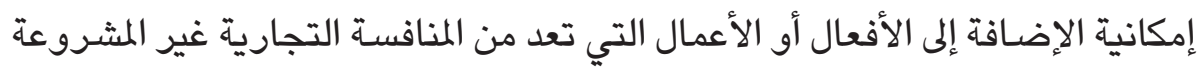

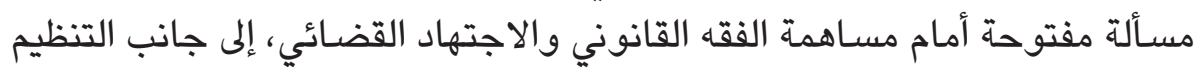

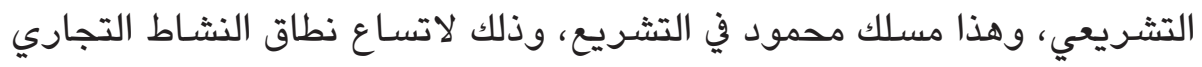

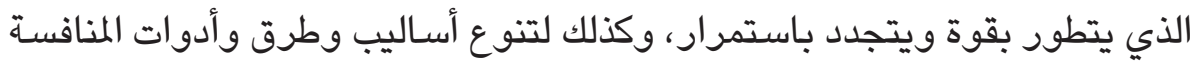

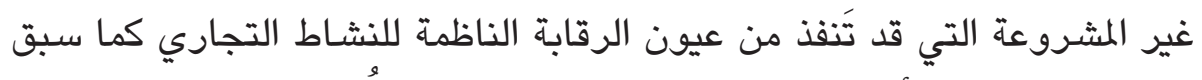

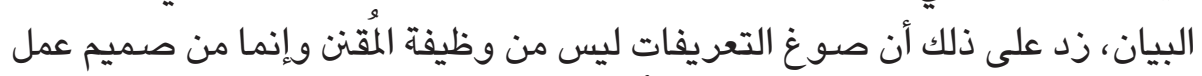

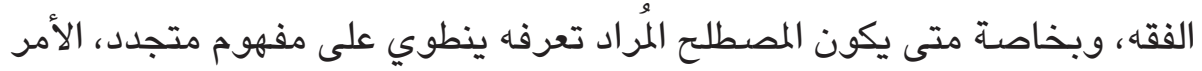
الذي يَحُدُ من التطور التلقائي للمفاهيم(2). ثالثاً - تعريف المنافسة غير المشروعة في القضاء:

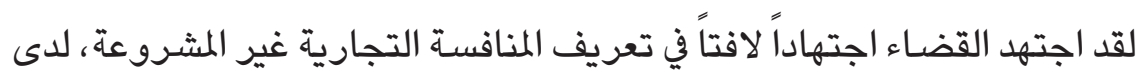

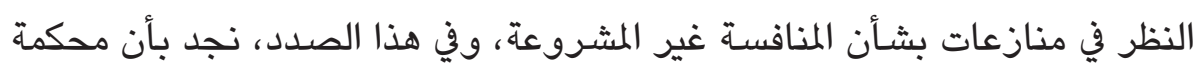

$$
\begin{aligned}
& \text { (1) سوف نعرض لهذه الصور في المبحث الثاني من هذه الدراسة. }
\end{aligned}
$$

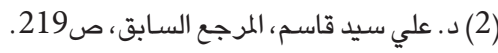


النقض الفرنسية قد ركزت لدى تعريفها المنافسـة التجارية غير المشروعة على أنها

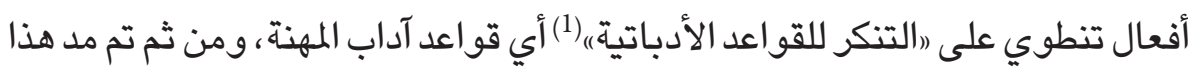

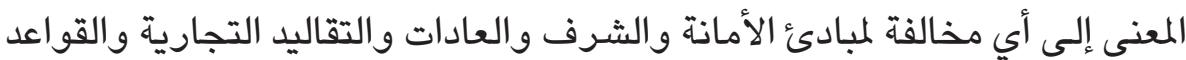

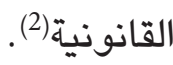

ومن جهتها ، فقد عرفت محكمة النقض المصرية، في ظل القانون المصري القديم(3)،

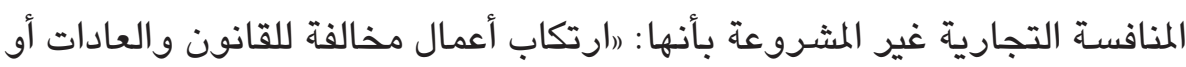

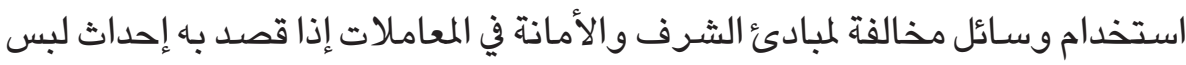
بين منشأتين تجاريتين أو إيجاد اضطراب بإحداهما متى كان من شأنه اجتذاب عملاء

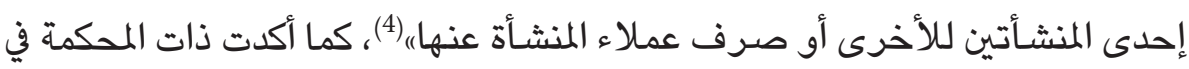

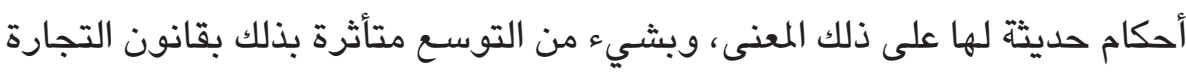

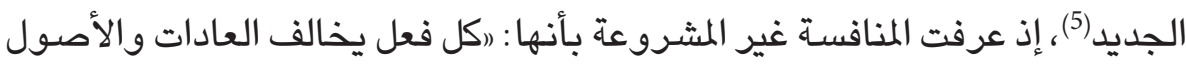

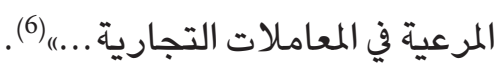

وأما محكمة التمييز الأردنية فقد عرفت المنافسة غير المشروعة بأنها: رالمنافسة

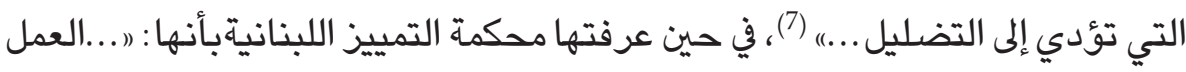

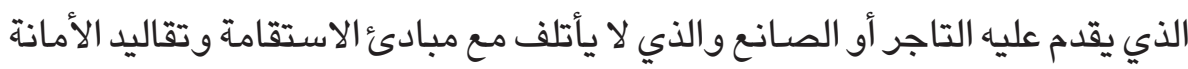

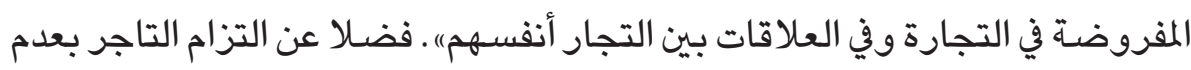

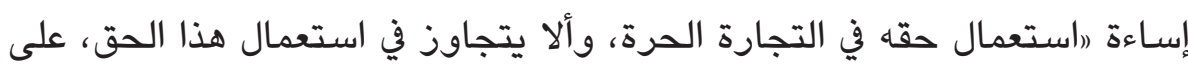
حقوق غيره من التجار)|(8).

$$
\text { (1) نقاًا عن د. لويس فوجال، المرجع السابق، ص776. }
$$

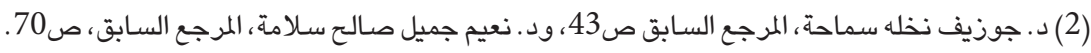

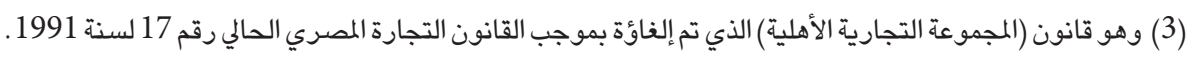

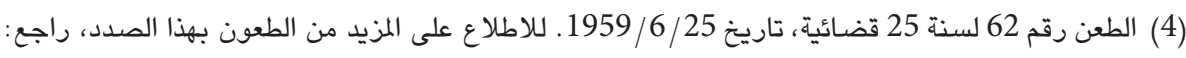

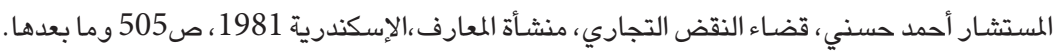

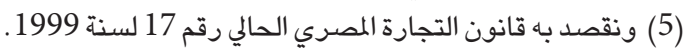

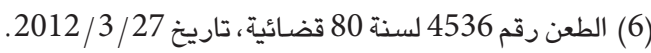

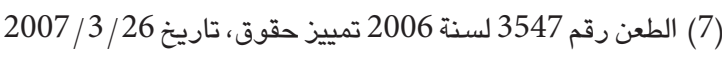

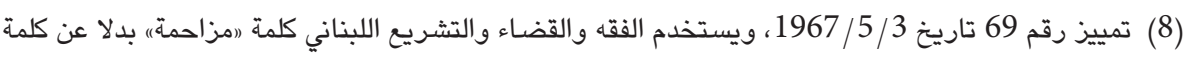

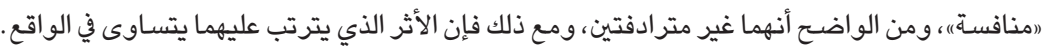


وفي هذا الصدد نجد أن محكمة التمييز القطرية قد أدلت بدلوها في تعريف المنافسة

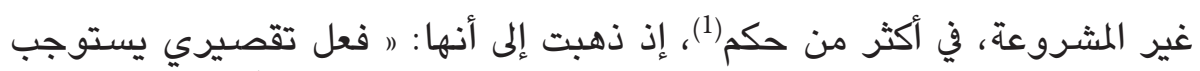

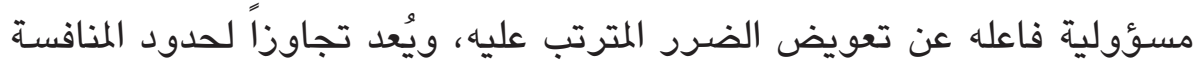

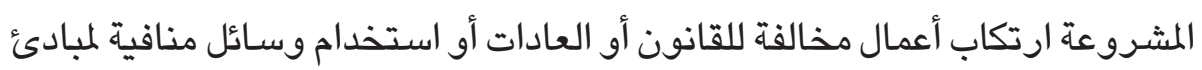

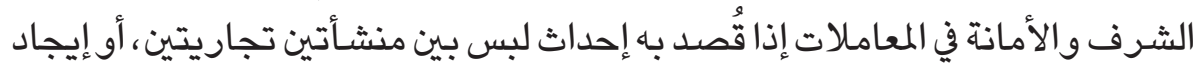

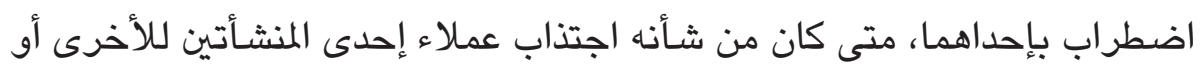
صرف عملاء المنشأة عنها)|(2).

وعلى ضوء من كل ذلك، نخلص إلى القول بأن مسألة إعطاء تعريف جامع مانع

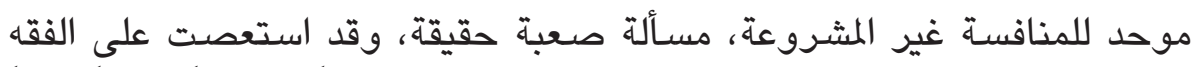

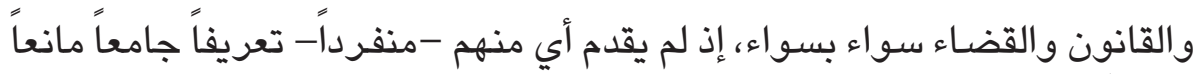
موحداً لها، ويعود ذلك إلى أكثر من سبب، من أبرزهاء الآتي (3): الأول: اتساع نطاق النشاط التجاري الذي يتطور بقوة، ويتجدد باستمرار، وييتدع الجديد على المستوى المحلي والإقليمي والدولي. الثاني: تنوع أسـاليب وطرق وأدوات المنافسة غير المشروعة التي تنفذ من عيون

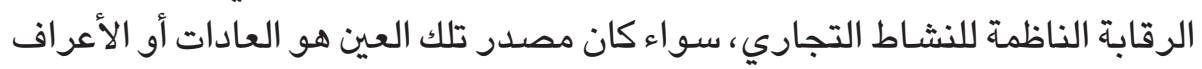
أو الأنظمة أو القوانين التجارية.

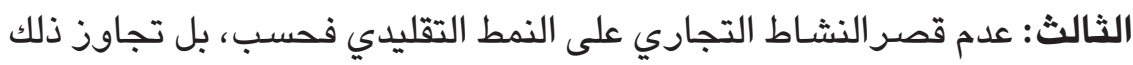

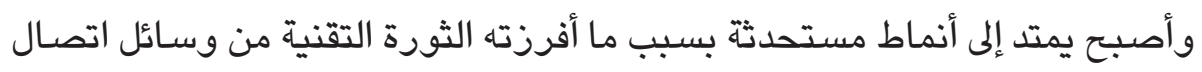
حديثة ومتنوعة(4).

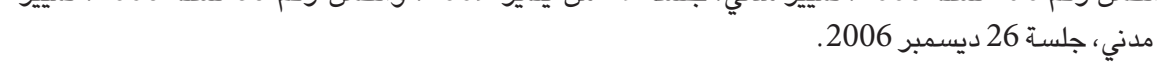

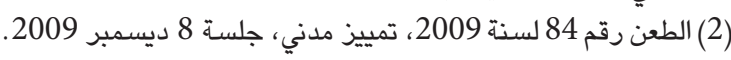

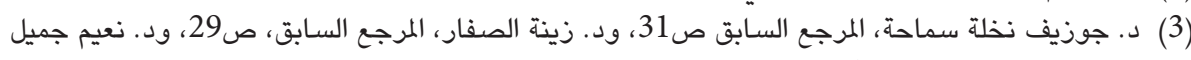

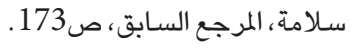
(4) د. كوثر سعيد عدنان خالد، حماية المستهلك الإلكتروني، دار الجامعة الجديدة، الإسكندرية 2012، 2013، ص 173 17 ، ود.

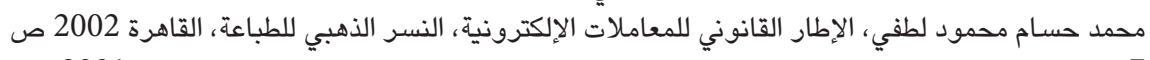

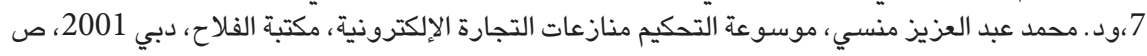

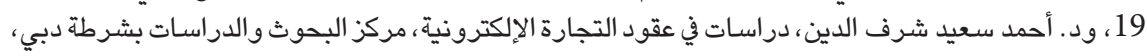

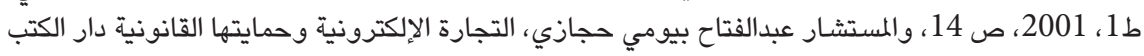

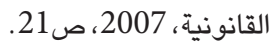


الرابع: التوسـع في التبصر والاحتياط لمستجدات النوازل ومقتضيات التطور،

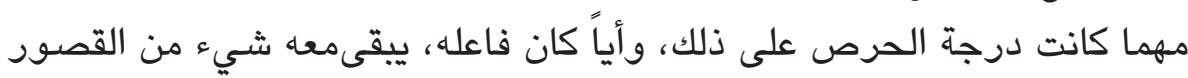
الملازم لذلك، كخاصية في البشر .

ومع ذلك نميل إلى القول بأن التعريف الفقهي والقانوني للمنافسة غير المشروعة السابق

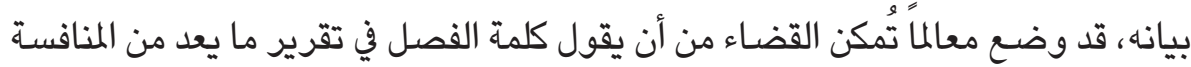

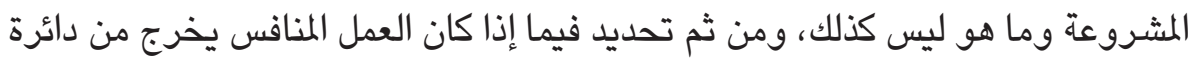

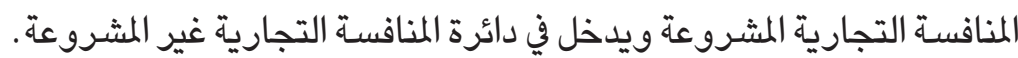
وأياً كان الأمر لا بد من التسليم بأن الفقه القانوني والنص التشريعي والاجتهاد

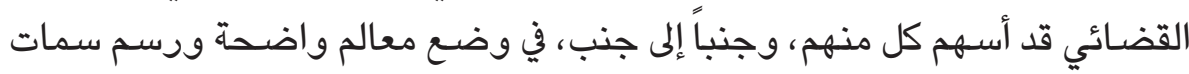
جامعة لحدود المنافسة غير المشروعة، تتمثل في الآتي (1): أولاً : إيجاد قاسم مشترك يربط بين أفعال أو أعمال المنافسـة غير المشروعة، يتمثل

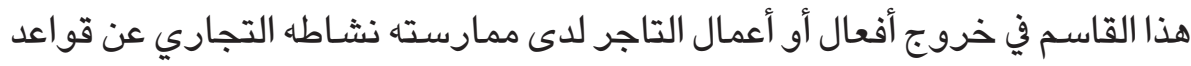

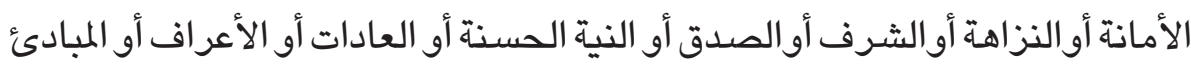
أو القواعد أو النظم التجارية السارية.

ثانياً : تركيز أفعال أو أعمال المنافسة غير المشروعة، في الأعم الغالب،بين التجار الذين يمارسون نشاطاً تجارياً متطابقاً أو مشابهاً أو متقارياً.

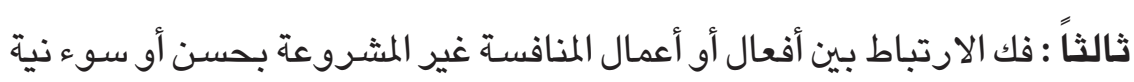
مرتكبها، وربطه بالضرر المترتب عليها ، والذي يلحق الآخرين. رابعًاً : عدم قصر الحماية من أفعال أو أعمال المنافسة غير المشروعة على التاجر

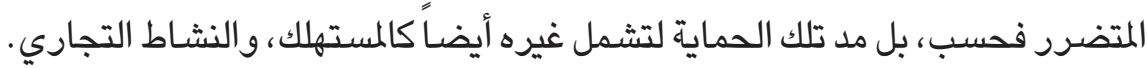
خامساً: : عدم الربط بين هدف التاجر الذي يرتكب أفعال أو أعمال المنافسـة غير

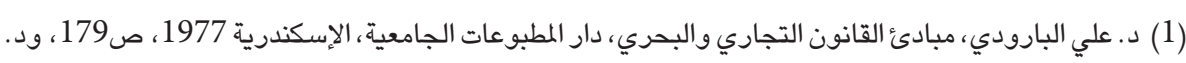

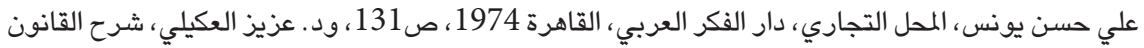

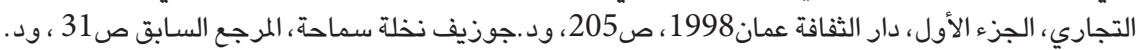

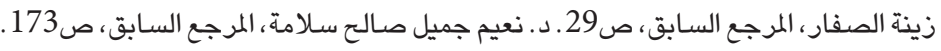


المشروعة وبين تحقيقه من جراء ذلك ربحاً، فقد يرتد ضرر ذلك عليه ، كما في حالة

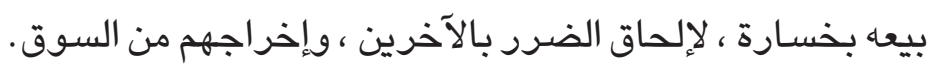

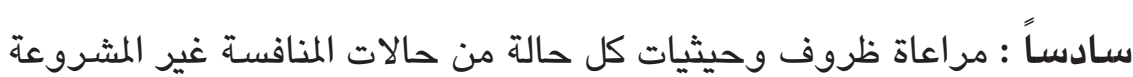

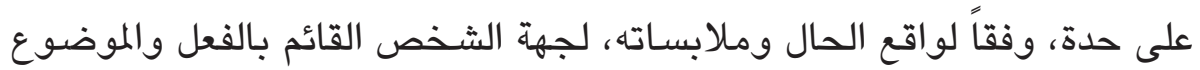

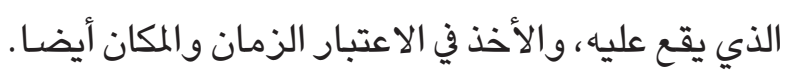
وعلى ضوء ما سبق ، يمكن القول بأن المنافسـة غير المشروعة تعني (اكل ممارسة

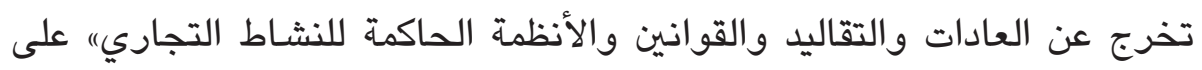
المستوى الوطني أو الدولي.

\section{الفرع الثاني}

\section{معيار المنافسة غير المشسروعة}

نحاول في هذا الفرع الوقوف على المعيار الذي يمكن الاستناد إليه في فرز أفعال أو

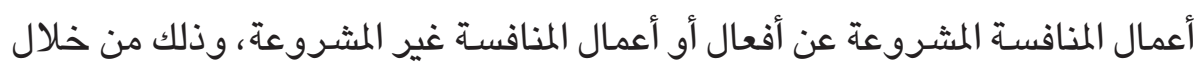
استعراض موقف الفقة والقانون والقضاء بهذا الصدد. أولاً - معيار المنافسة غير المشسروعة في الفقه:

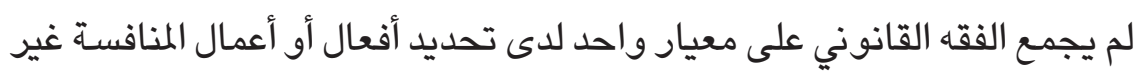

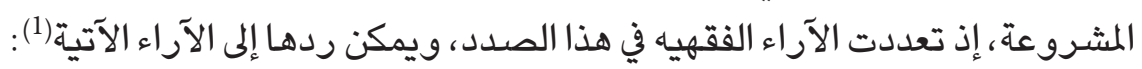
الرأي الأول - نادى بتحديد أفعال أو أعمال المنافسة غير المشروعة بالنص

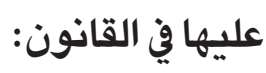
جوهر هذا الرأي أنه يجعل من النص القانوني المعيار الحاسم لتمييز أفعال أو أعمال

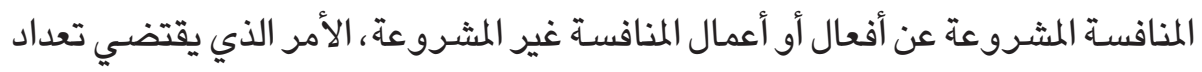

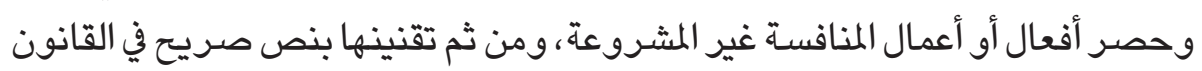

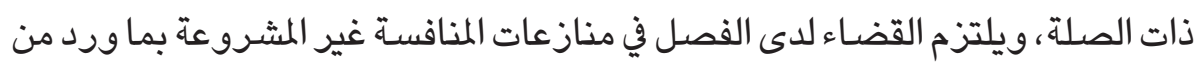
أفعال أو أعمال المنافسة غير المشروعة بالنص القانوني دون تجاوز ذلك. (1) د. جوزيف نخلة سماحة، المرجع السابق ص31، ود. زينة الصفار، المرجع السابق، ص31. 
ولا يخفى أن هذا الرأي يتناغم مع المنطق السليم، ومع ذلك لم يسلم من الانتقاد،

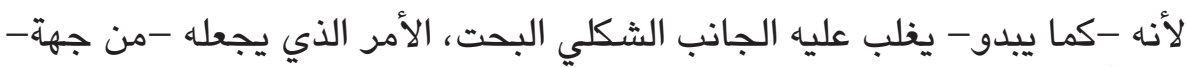

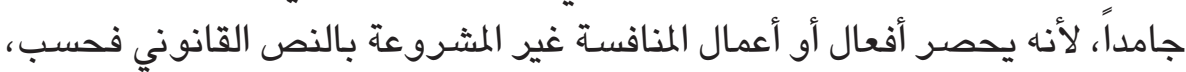

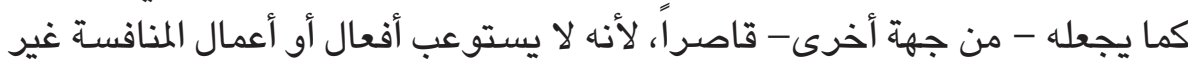

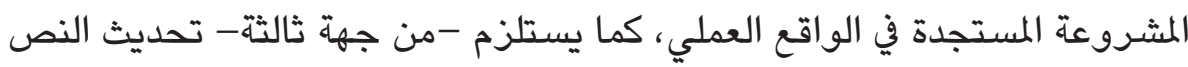

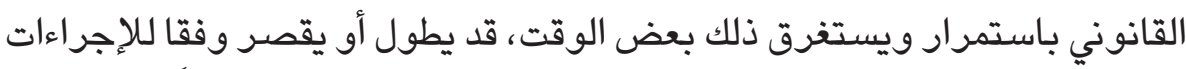

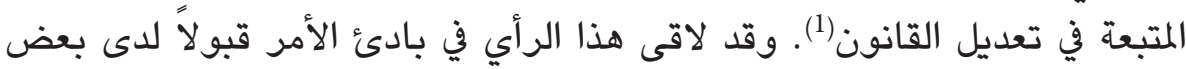

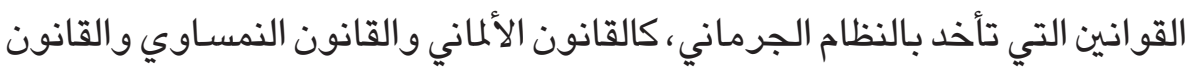

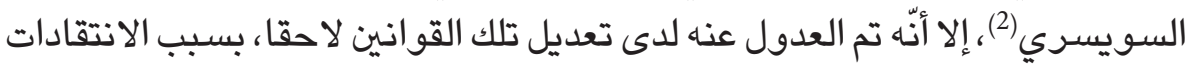
المذكورة التي وجهت إليه (3).

الرأي الثاني - نادى بترك تحديد أفعال أو أعمال المنافسة غير المشروعة

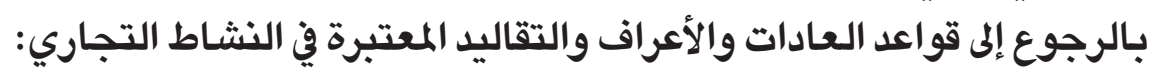
يتبنى هذا الرأي المفهوم المجتمعي لأهل النشاط على اعتبار أنهم أدرى -منٍ

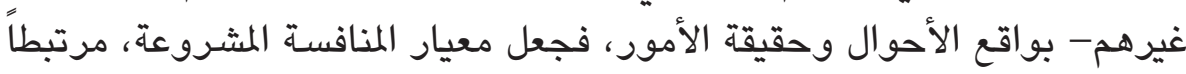

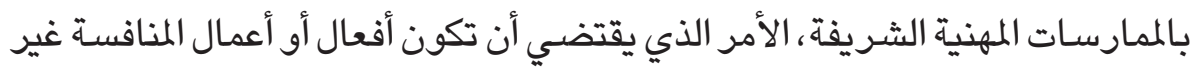

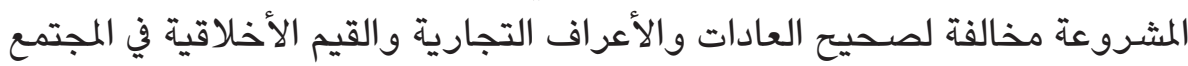

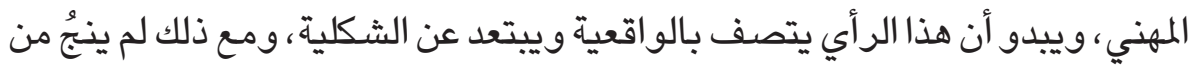

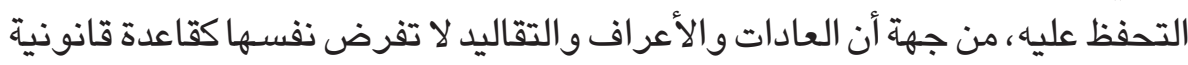

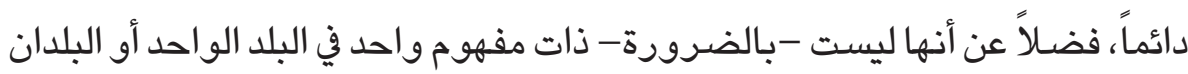

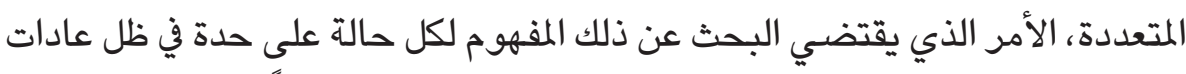

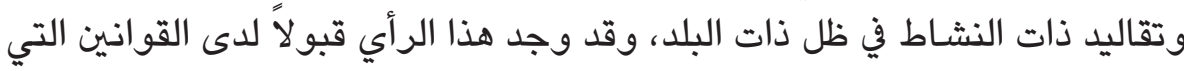

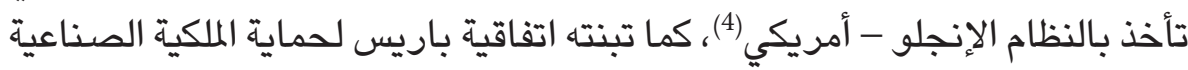

لسنة 1883(5).

(1) د. حسن كيرة، المدخل إلى القانون، الطبعة الخامسة، الإسكندرية 1973 ص 250 ـ 250.

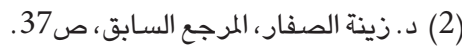

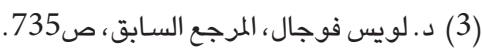

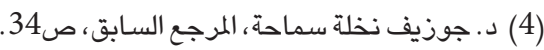

(5) المادة 10 ثانياً من الاتفاقية المذكورة. 
الرأي الثالث - نادى بتبني معيار الأخلاق لدى تحديد أفعال أو أعمال المنافسة غير المشروعة:

جعل هذا الرأي الأخلاق والآداب المهنية المعيار الأساسي الذي يتعين الاحتكام إليه

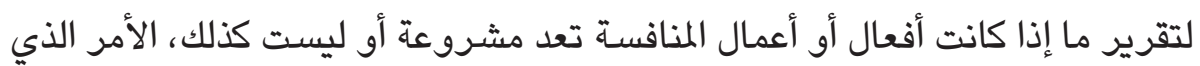

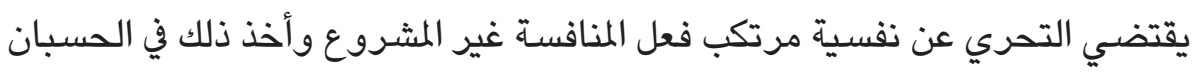

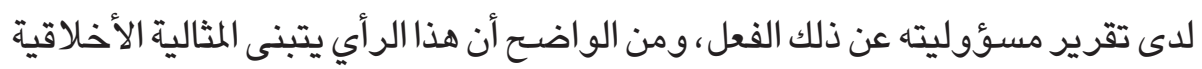

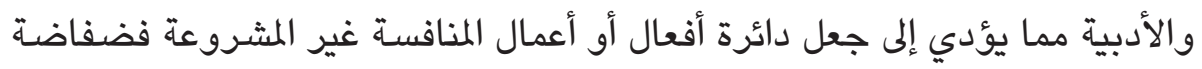

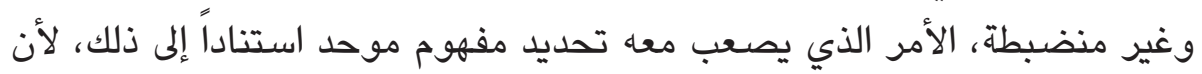

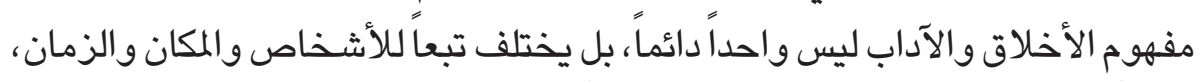

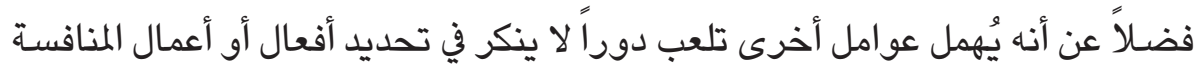

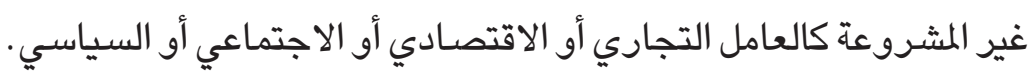

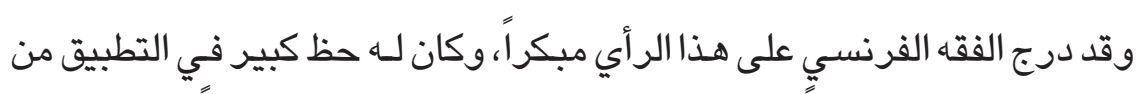

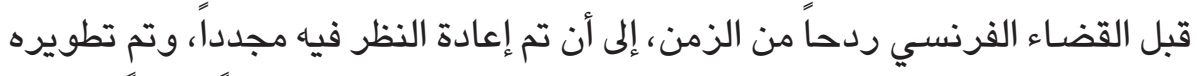

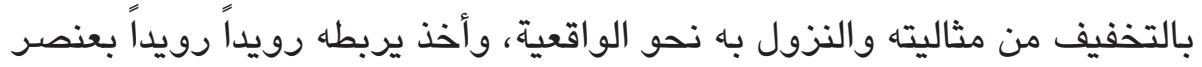

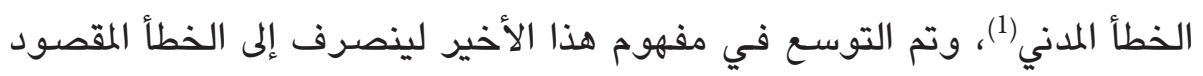

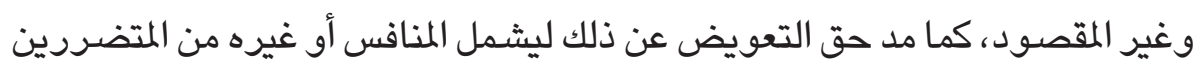

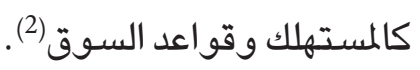
الرأي الرابع - نادى بترك استخلاص أفعال أو أعمال المنافسة غير المشروعة للقضاء: ينطلق هذا الرأي من صعوبة تحديد مفهوم المنافسة غير المشروعة؛ لأن دائرة

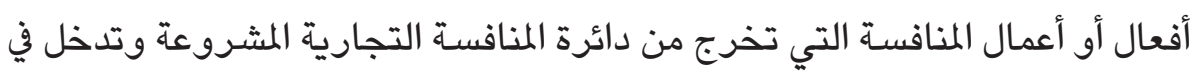

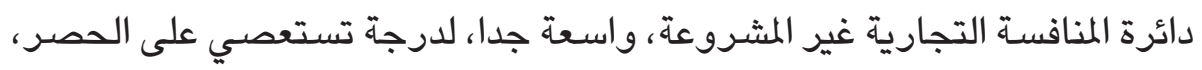

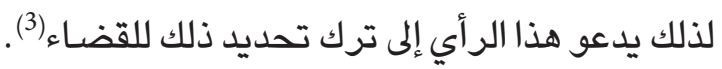

(1) ومن القوانين التي أخذت به -إلى جانب القانون الفرنسي- القانون الإيطالي والهولندي والبلجيكي. د. جوزيف

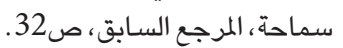

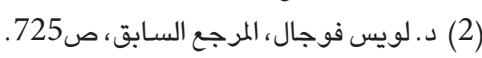

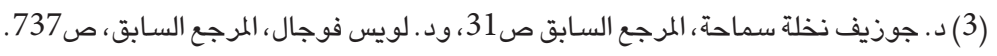


ويؤخذ على هذا الرأي أنة يبالغ في الواقعية التي تُبنى على الحالات الجزيئة

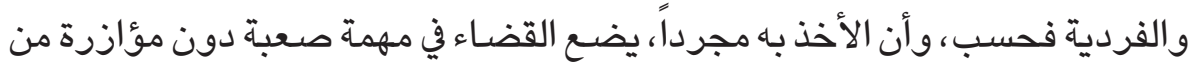
الاجتهاد الفقهي أو سند من النص القانوني.

ولا يخفى أن الآراء المذكورة تنهض دليلاً على أن الفقه القانوني التجاري لم

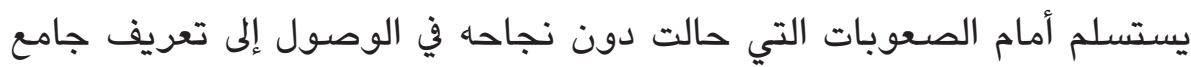
وشـامل وواف وكاف للمنافسة التجارية غير المشروعة مثلما تقدم البيان، كما أنها

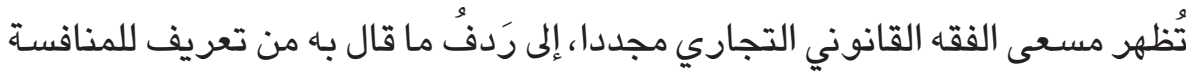

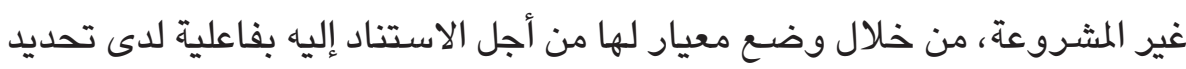

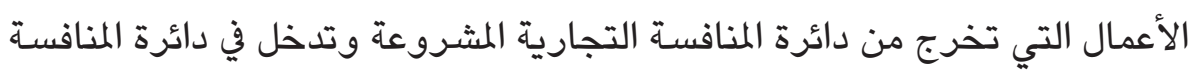
التجارية غير المشروعة.

والواتع أنه يصعب الوصول إلى الغرض المنشود من ذلك، بالاستناد إلى أحد

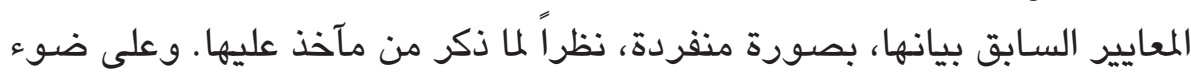

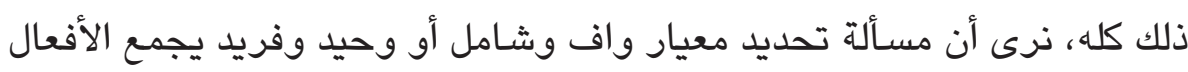

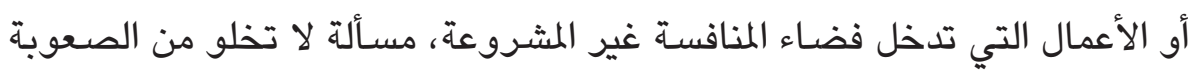

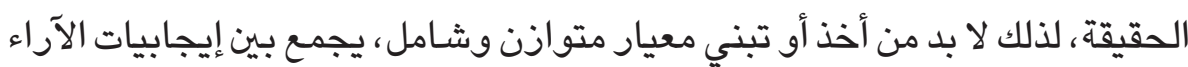

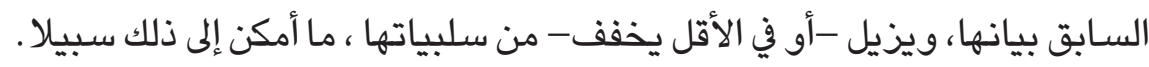
ثانياً - معيار المنافسة غير المثروعة في القانون: على ضوء الآراء الفقهية السابق بيانها، وأمام الصعوية الحقيقة التي واجهتها

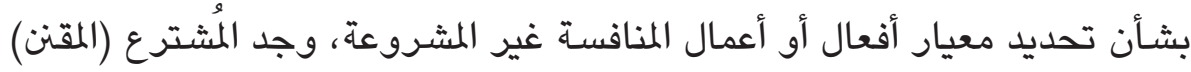

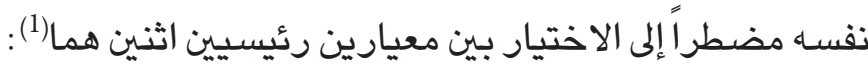

المعيارالأول : الاكتفاء بالنص على مبدأ عام في القانون المدني يستند إليه في تنظيم

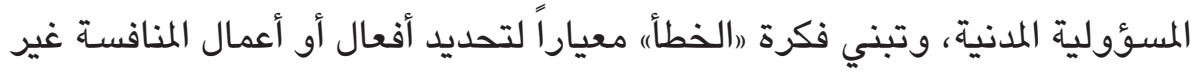
المشروعة التي تلحق (الضرر) بالمنافس الآخر ، ومن ثم (تعويضيه المضرور من تلك

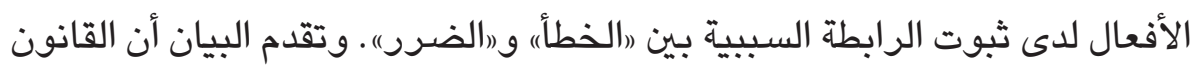

(1) د د. نعيم جميل صالح سلامة، ، المرجع السابق، ص212. 
الفرنسي(1) يأتي على رأس القوانين التي سلكت هذا المسلك، ومن ثم امتد ذلك إلى عدد من قوانين الدول الأخرى التي تأثرت به أو جارته في ذلك ، كالقانون الإيطالي

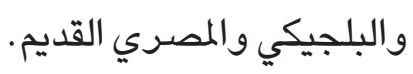

المعيار الثاني: عدم الاكتفاء بالنص العام الذي يرد في القانون المدني أو التجاري،

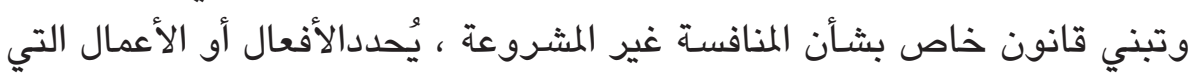

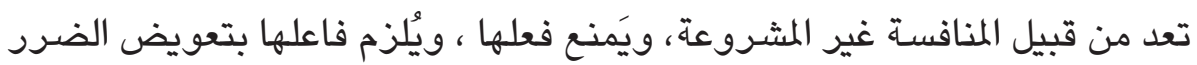

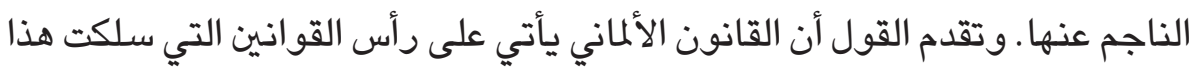

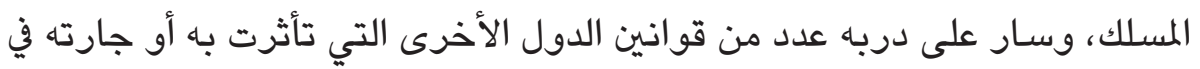

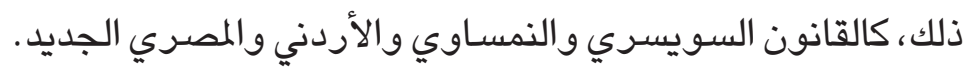
وفي الحقيقة فإنه لا غرابة في تبني أي من المعيارين المنكورين، لأنهما يتفقان في

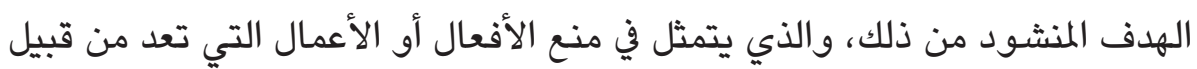

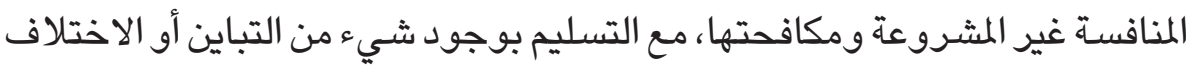
بينهما في مسألتين اثنتين، هما:

الأولى: تحديد مدى أو نطاق منع الأفعال أو الأعمال التي تعد من قبيل المنافسة غير

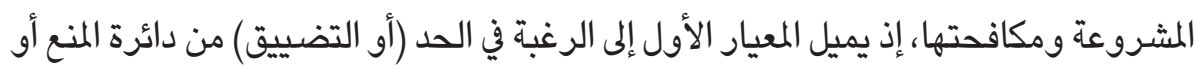
المكافحة، أما المعيار الثاني فيميل إلى الرغبة في الفتح (أو التوسيع) من دائرة المنع أو المكافحة. الثانية: تحديد الجهة المستهدفة من الحماية، إذ تتركز الحماية في المعيار الأول حول

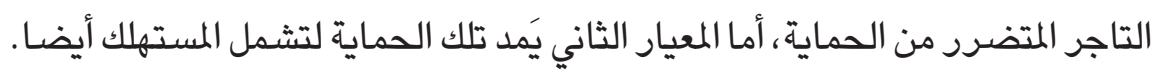
ويمكن القول أنه لا ضير من هذا التباين (أو الاختلاف) بين المعيارين المذكورين، لأن

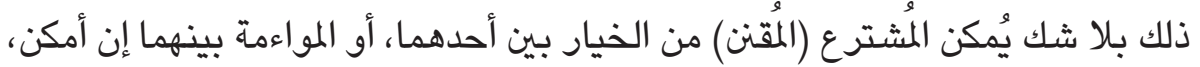

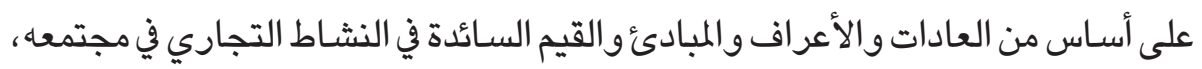
وعلى ضوء العوامل الاقتصادية والاجتماعية والسياسية الناظمة في بلاده.

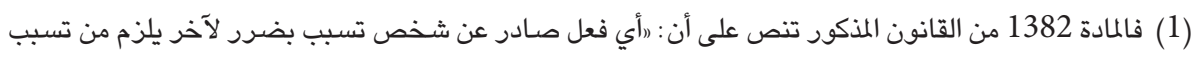

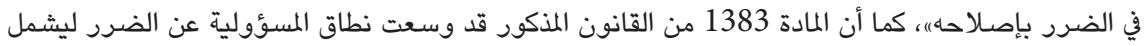

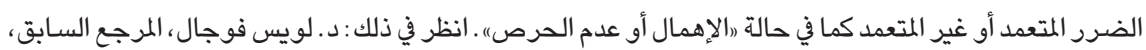

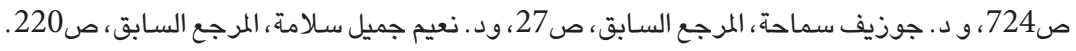




\section{موقف القانون القطري من ذلك:}

لقد تبنى القانون القطري المعيار الأول ، بدليل منطوق المادة 199 من القانون المدني

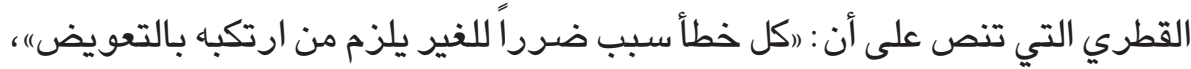
الأمر الذي يظهر بجلاء تام تأسيس وتنظيم معيار المسؤولية المدنية على فكرة (الخطأ)،

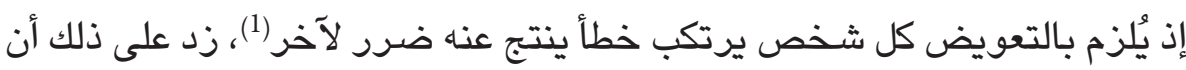

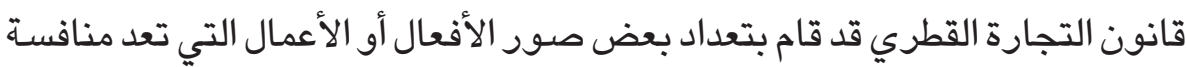

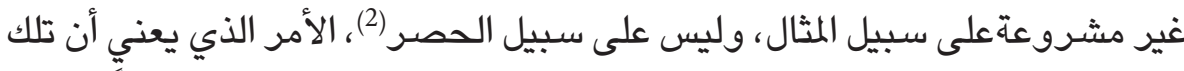

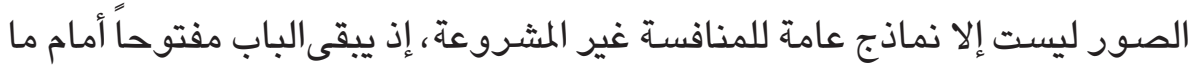

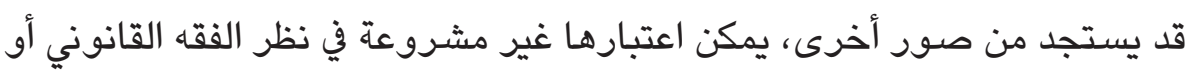

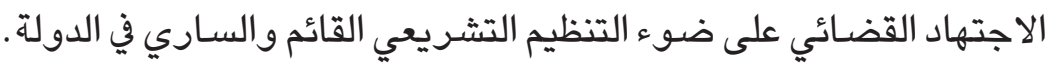

\section{ثالثاً - معيار المنافسة غير المشروعة في القضاء:}

من المعلوم أن القضـاء صـاحب كلمة الفصل في تطبيق النص القانوني على المنازعات

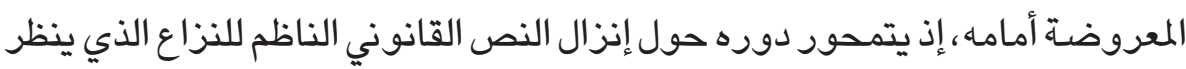
فيه بعد تكييفه، ومن ثم يصدر القرار المقتضى، وفقا للأصسول القانونية السارية.

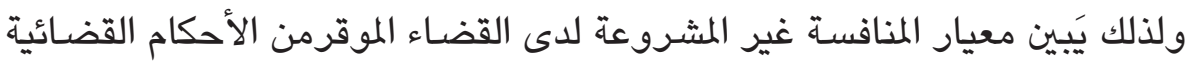

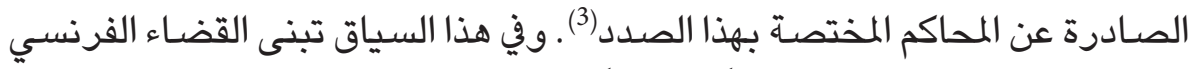

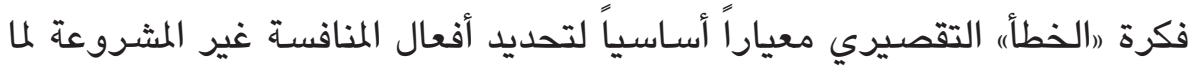

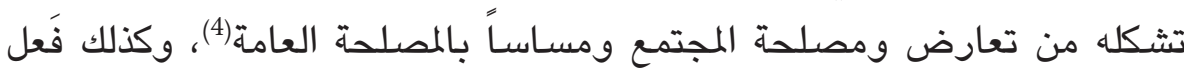

$$
\text { (1) وذلك بدلالة المادتين } 200 \text { و 201 من من القانون المذكور. }
$$

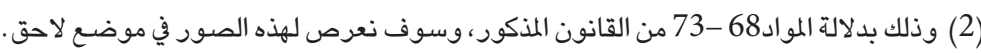

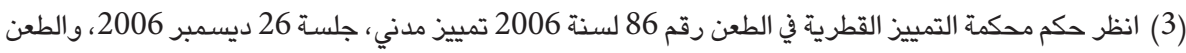

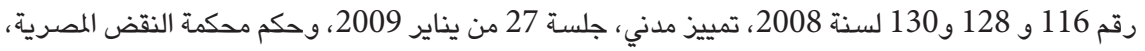

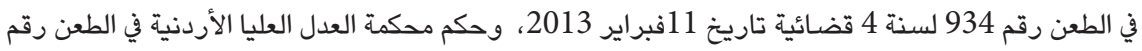

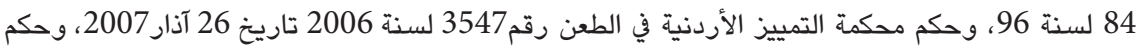
محكمة التمييز الكويتية في الطعن رقم 156 لسنة 82 تاريخ 9 فبراير 1983 لـونية وللمزيذ من الاطلاع على الاجتهاد القضائي ،يمكن رؤية الروابط الآتية: http://www Eastlaw.qa/RulingPage.aspx?id=590. http://www.adaleh.info/page.asp?pagelD=2 (4) نقلاً عن د. لويس فوجال، المرجع السابق، ص730، ود . نعيم جميل صالح سلامة، المرجع السابق، ص128. 
القضاء المصري الذي جعل من "الخطأ)، بمعناه الواسع معياراً يتم الاستناد إليه في

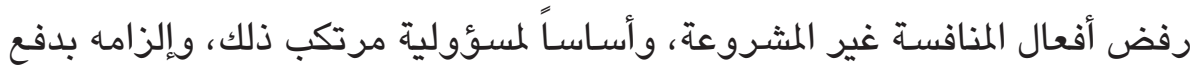

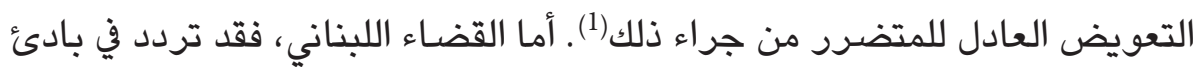

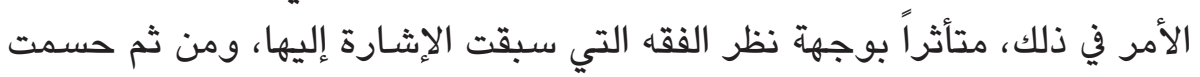

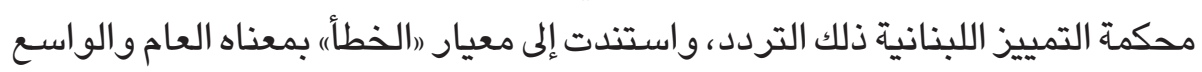

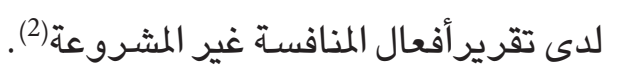

وقد سار القضاء القطري على ذات الدرب ولم يخرج عما ذكر ، إذ تَبنى بجلاء

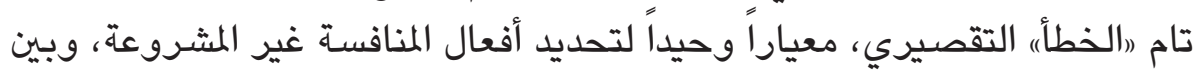

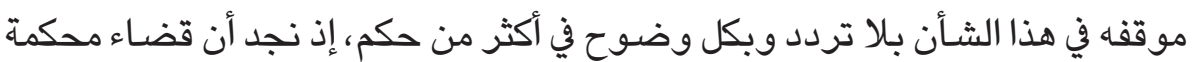

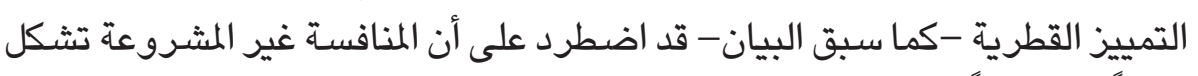

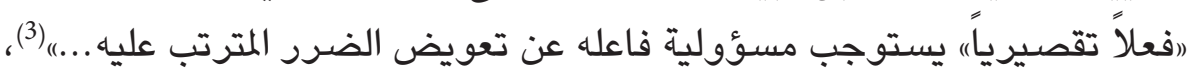

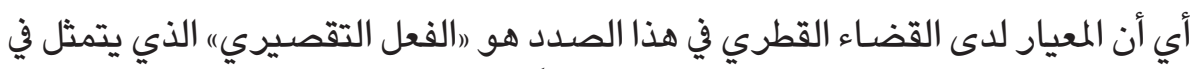

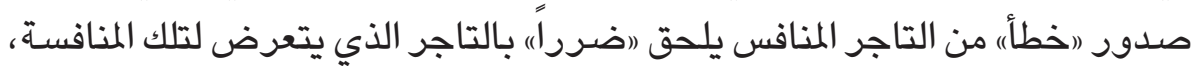

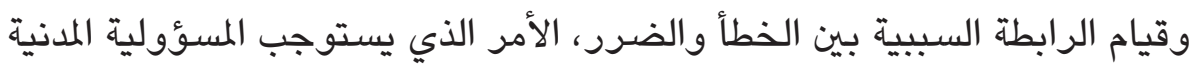
وفقا للقواعد المقررة بهذا الصدد.

وعلى ضوء ما سلف، نرى أن موقف الفقه القانوني والنص التشريعي والاجتهاد

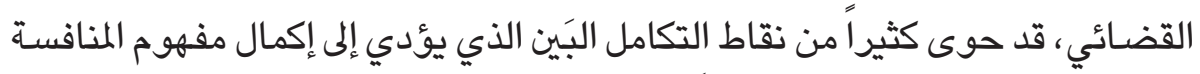

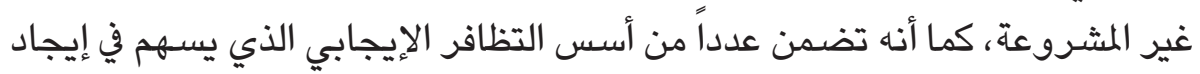

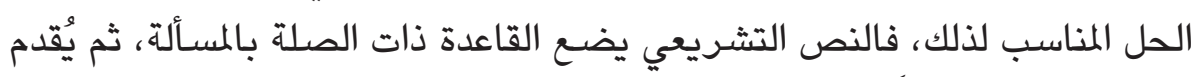

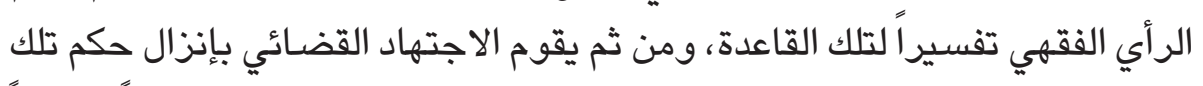

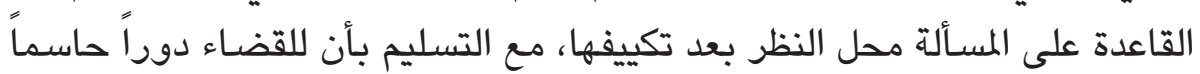

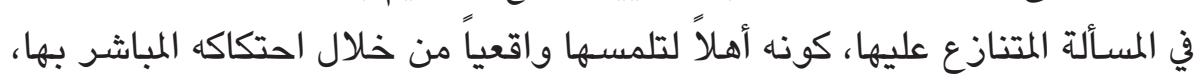
وسَماعه لأطرافها، ومعرفة واقع الحال وملابساته، والاجتهاد بالفحص ولاندان والتدقيق

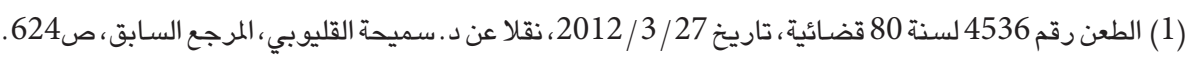

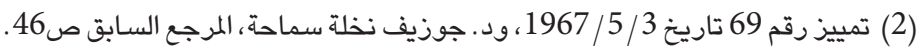

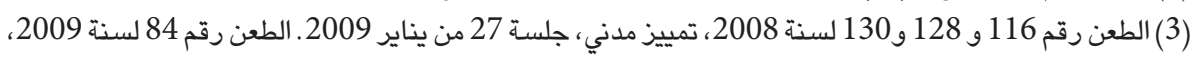

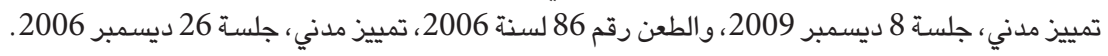


والتكييف، ساعياً من وراء ذلك كله الوصول إلى تميز صالح الأفعال أو الأعمال من طالحها، ومن ثم يتم فرز المشروع منها عن غير المشروع.

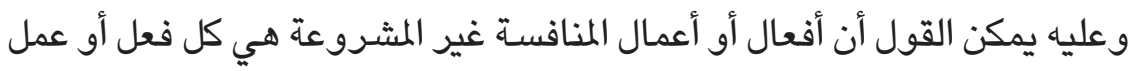

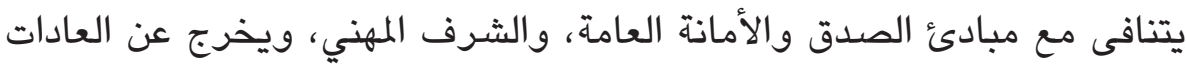

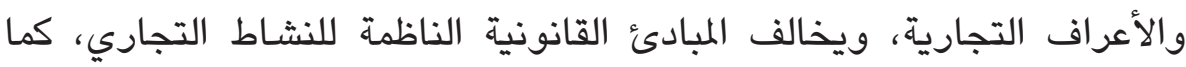

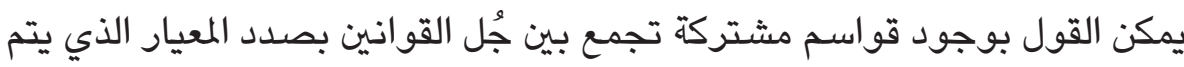

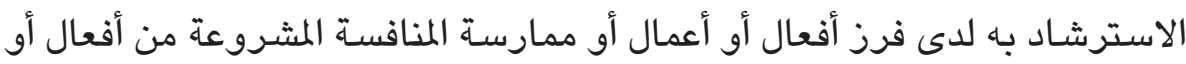
أعمال المنافسة غير المشروعة، ومن ثم يعرف الصحيح منها من غير الصدية الصيح.

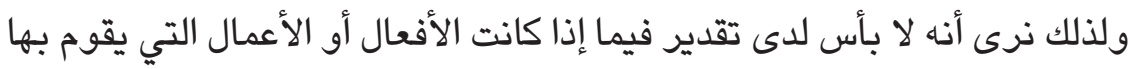

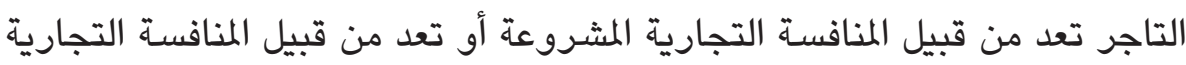

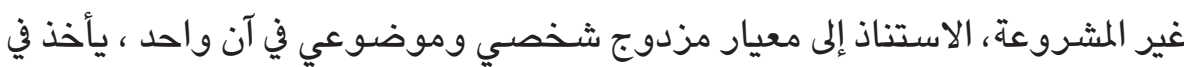

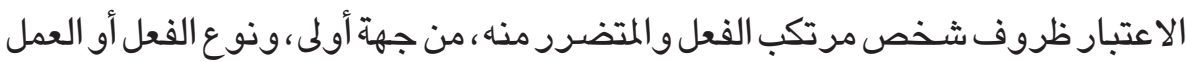

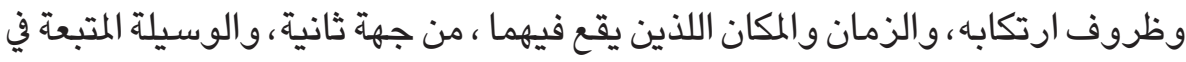

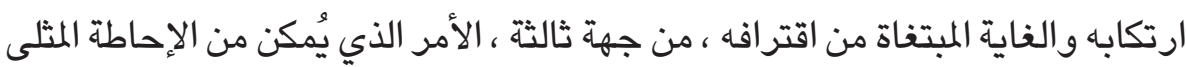

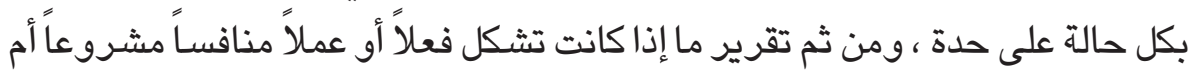
غير مشروع ، فذلك يسهم بقوة في رصد صدور المنافسة غير المشروعة. وعلى ضوء ما سبق، يمكن القول بأن معيار المنافسة غير المشروعة يتمثل في

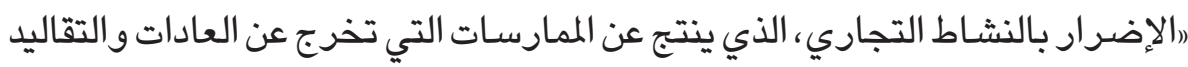

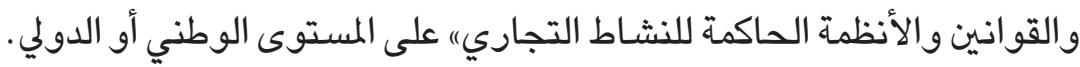

\section{المطلب الثاني}

\section{تمييز المنافسة غير المشروعة عن المنافسة الممنوعة}

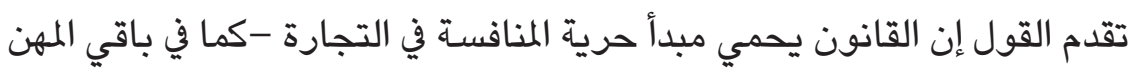

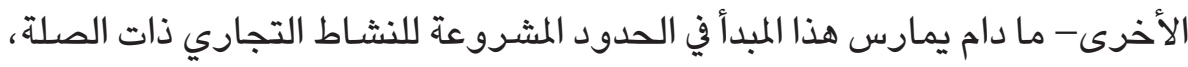

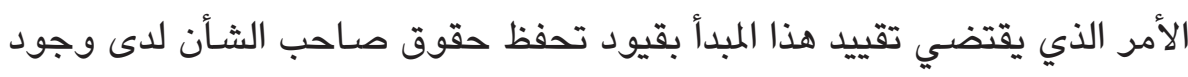

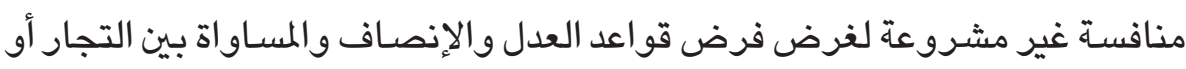


لدى وجود منافسة ممنوعة بنص القانون، لغرض فرض احترام النص القانوني الذي

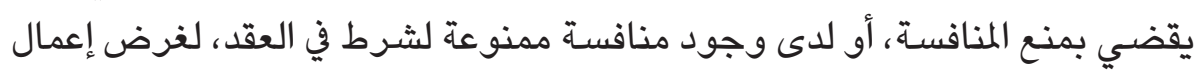

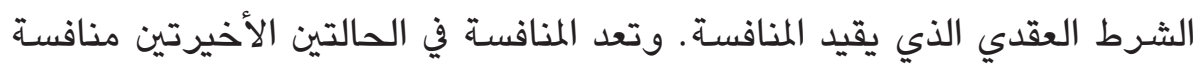

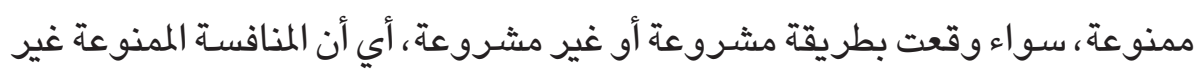

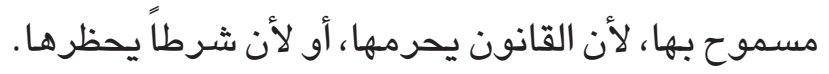

ونحاول في هذا المطلب التمييز بين المنافسة غير المشروعة وبين المنافسـة الممنوعة، سواء لنص قانوني أو لشرط عقدي، وذلك في فرعين على التوالي.

\section{الفـرع الأول}

\section{المنافسة غير المثروعة والمنافسة الممنوعة بنص القانون}

تَعني المنافسة غير المشروعة -كما سلف البيان- خروج التجار لدى ممارستهم نشاطهم التجاري عن الوسائل الشريفة التي يجب عليهم الالتزام بها، وتتجسد التها

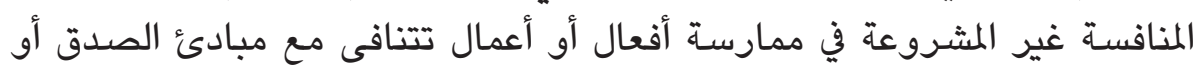

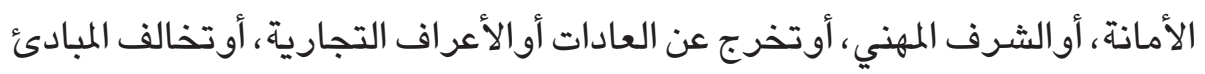

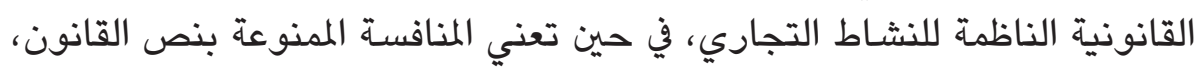

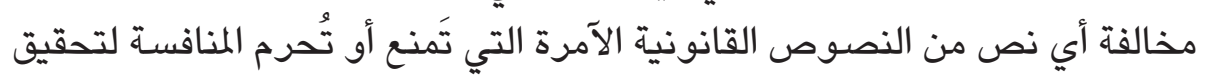

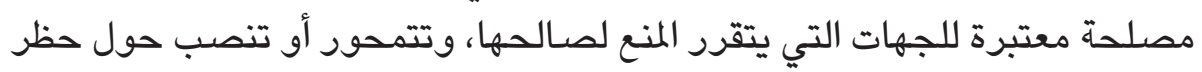

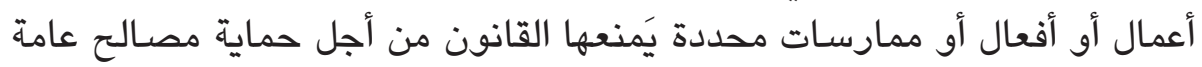

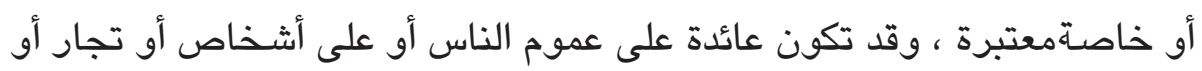

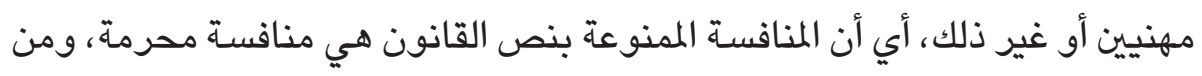

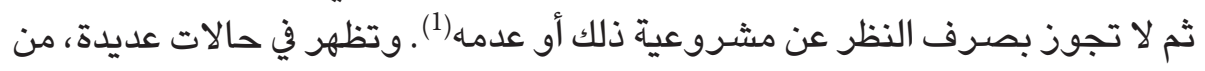

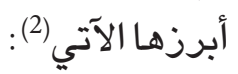

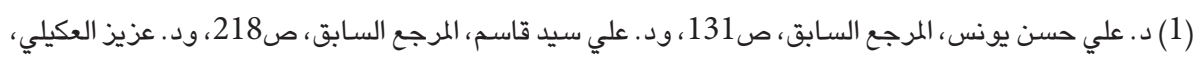

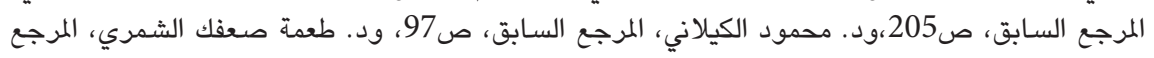

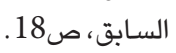

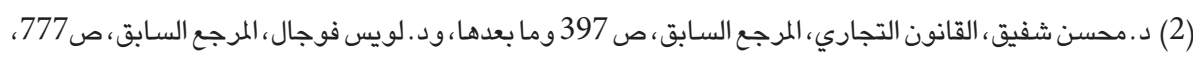

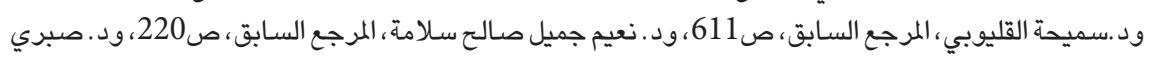

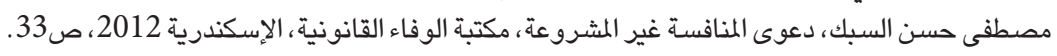




\section{أولاً - حالة حقوق الامتياز:}

تعطي الدولة حقوق امتياز تجارية لجهات معينة لاستغلال أنشطة محددة لمدد مؤقتة،

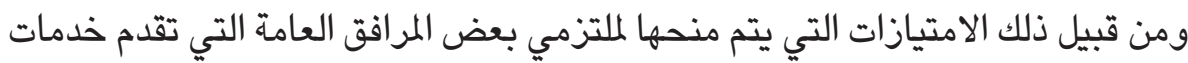

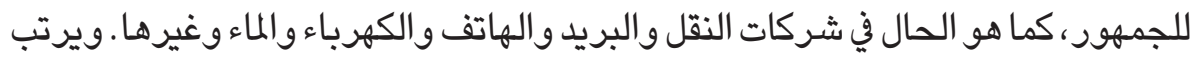

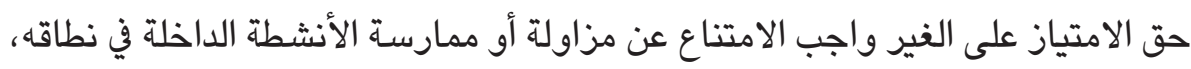

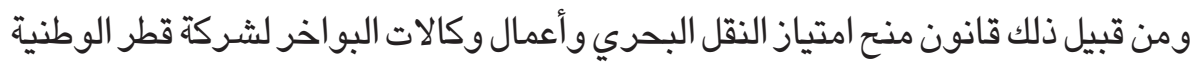

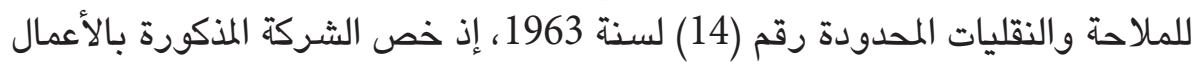
المذكورة، وكل من يخالف ذلك)، يعاقب بالحبس والغرامة أو إحداهما)(1). ويُعد مخالفة حقوق الامتياز منافسة ممنوعة لخرقها نص قانوني آمر، سواء

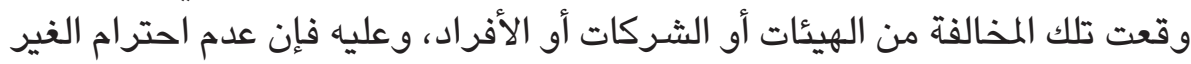

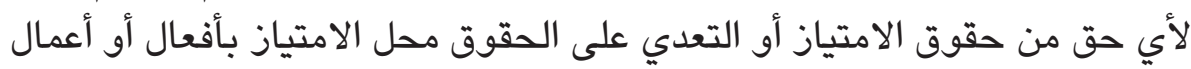

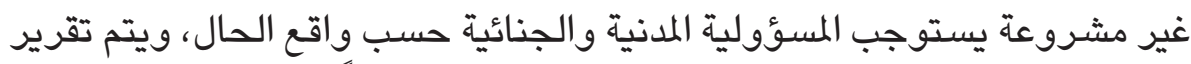

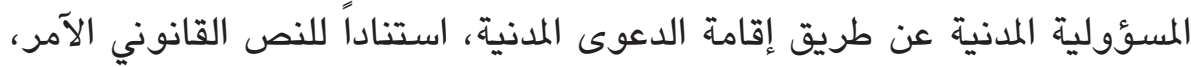

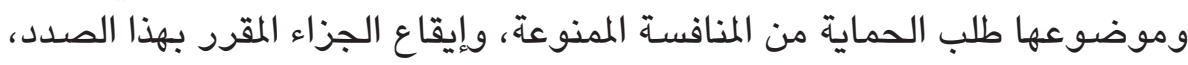
وبخاصـة التعويض الذي يستحقة المضرور جراء التعدي على حقوقه القانونية النابعة من موضوع الامتياز المقرر له. ثانياً - حالة حقوق الاستئثار: يُعطي المُشترع (المقتنن) القطري حقوقاً استئثارية لأصحاب الحقوق الفكرية(2)

(1) المادتان 2 و11 القانون المذكور ، ويلاحظ على هذا القانون أنه يشير إلى العملة القديمة (الروبية) التي كانت سارية في

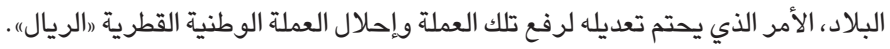

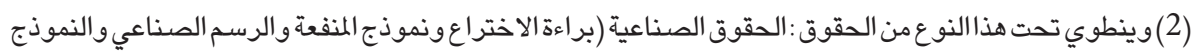

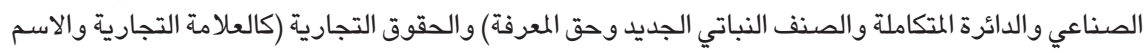

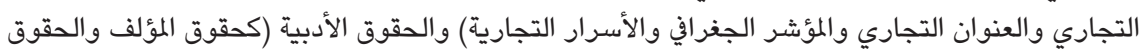

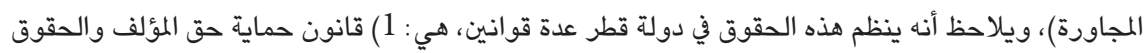

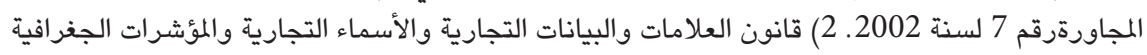

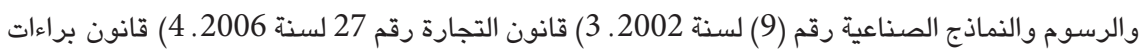

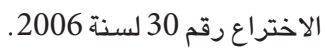

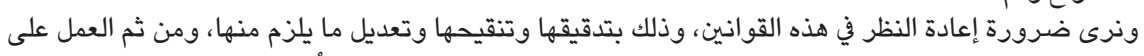

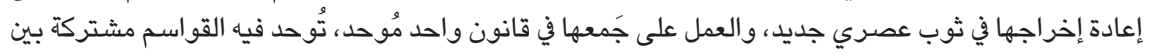
هذه الموضوعات لجهة الشكل والموضوع. 
من أجل تمكينهم من الانفراد في استغلال هذه الحقوق في نطاق القانون الناظم

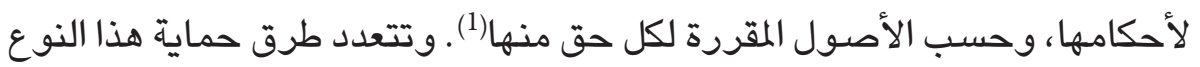
من الحقوق، فقد تأخذ طريق الحماية الإدارية أو الاجرائية أو المدنية أو الجزائية

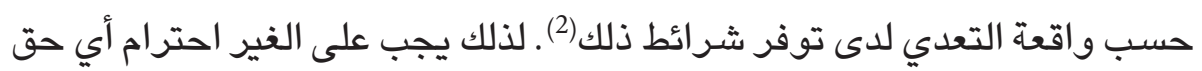

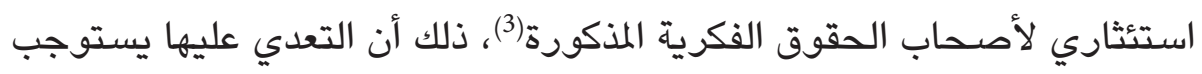
المسؤولية القانونية حسب واقع الحال(4) وبخاصـة دخول فعل التعدي في دائرة المنافسة الممنوعة بنص القانون. ويتم تقرير المسؤولية المدنية عن طريق إقامة

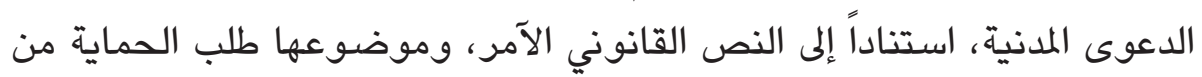

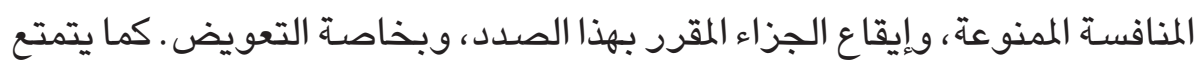

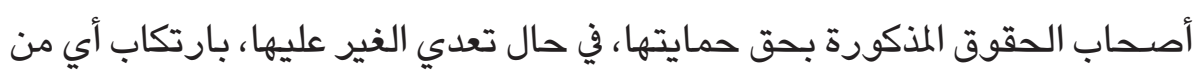

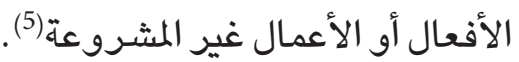 ثالثاً - حالة مزاولة المهن الحرة:}

ليس من شك أن المهن الحرة تتميز بأنها تقوم على تقديم خدمة فكرية أو ذهنية) (6)،

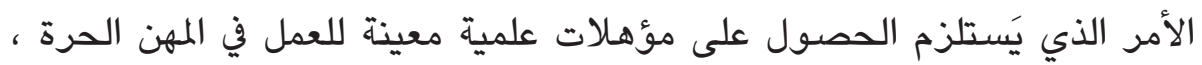

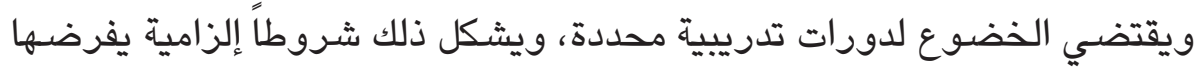

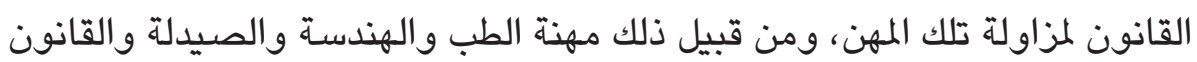

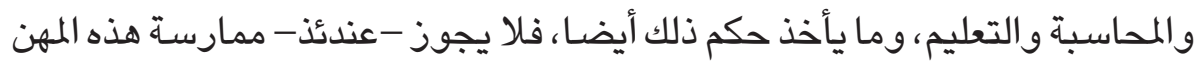

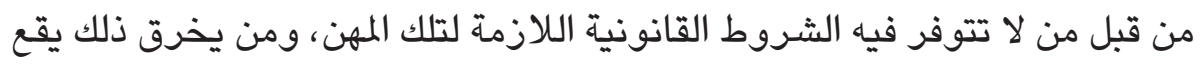

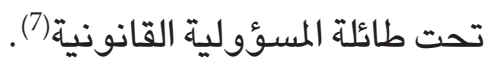

(1) د. صلاح زين الدين، شرح قانون براءات الاختراع القطري رقم 30 لسنة 2006، دار وائل، عمان 2010، ص161 ـ16.

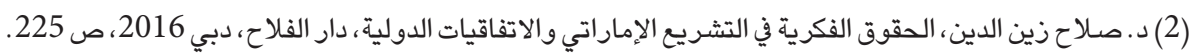

(3) Sylvia Kierkegaard, International Law And Trade, First edition, Ankara Barosu,

Ankara, 2007, p297.

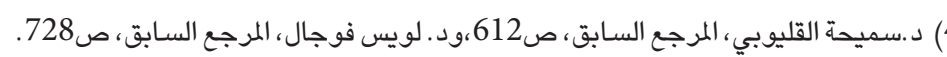

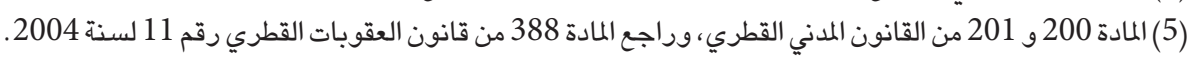

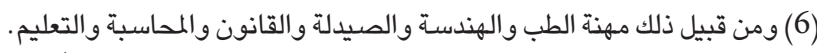

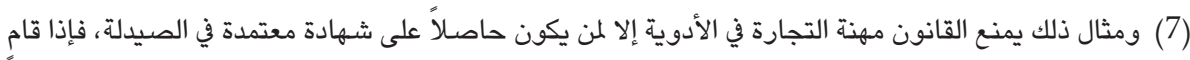

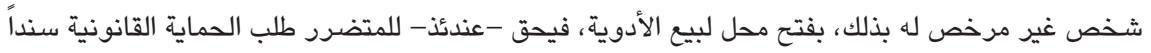
لمخالفة النص القانوني ذات الصلة. 


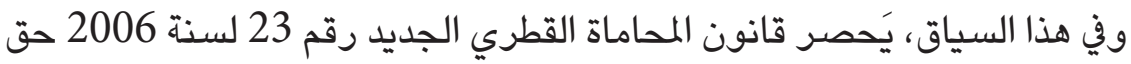

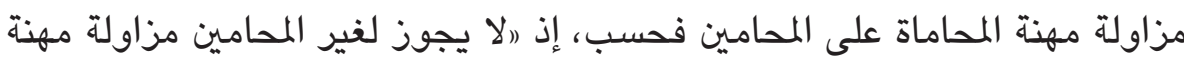

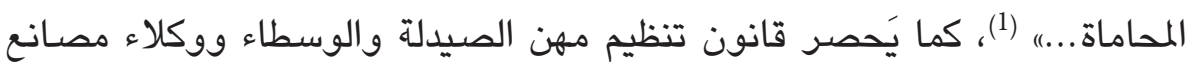

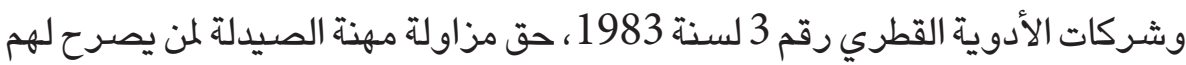

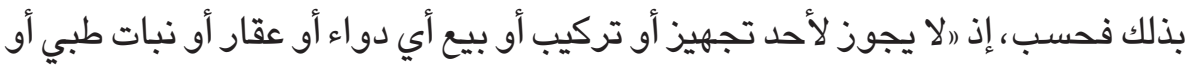

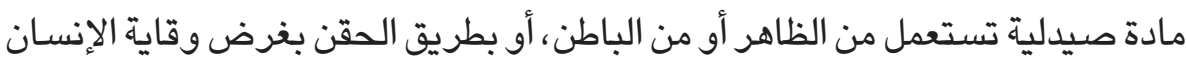

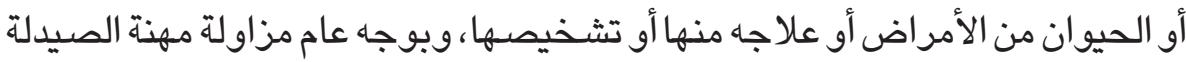

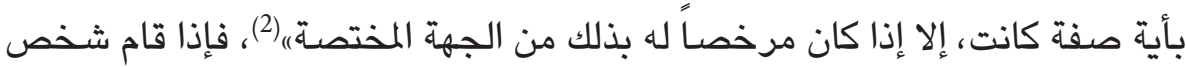

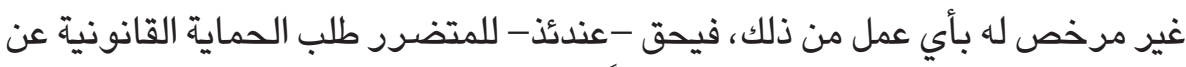
طريق إقامة دعوى المنافسة الممنوعة، سنداً لمخالفة النص القانوني ذات فئس الصلة. وعليه لا يجوز ممارسة المهن الحرة من قبل من لا تتوفر فيهم الشروط القانونية

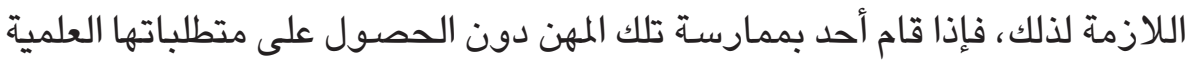

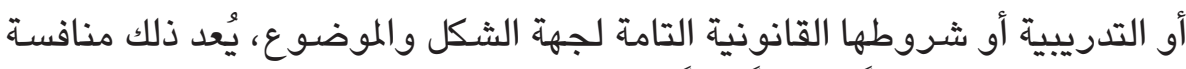
ممنوعة، لمخالفته نصاً قانونياً أمراً، ويقع تحت طائلة المسؤولية القانونية بشقيها

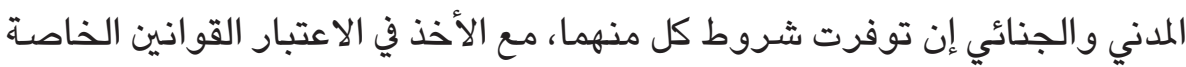
بهذه المهن التي تقتضي المساءلة الإدارية (التأديبية).

\section{رابعاً - حالة حماية المستهلكين:}

تَقضي محاربة الغش التجاري تدخل المُشترع (المُقنن) لفرض بيانات تجارية

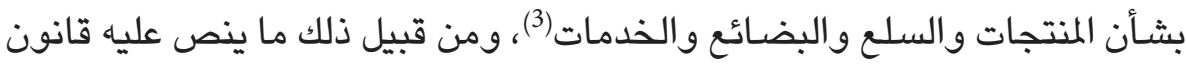

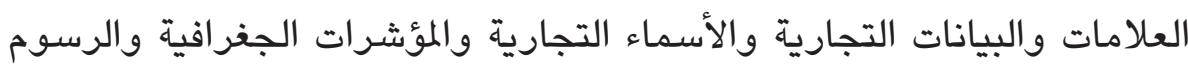
والنماذج الصناعية رقم (9) لسنة 2002 القطري، بشأن لزوم إيضاح البيات الباتات

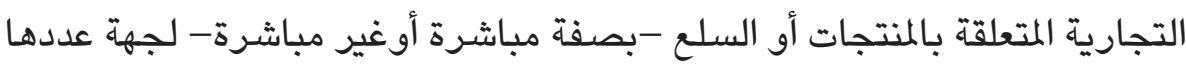
أو مقدارها أو مقاسـها أو كميتها أو طاقتها أو وزنها أو طريقة صنعها أو أو أو إنتاجها

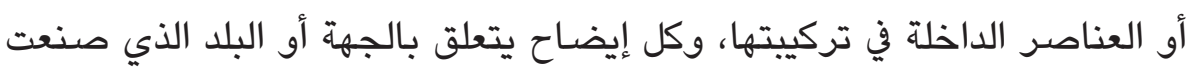
(1) - (1) - (المادة 3 من القانون المذكور.

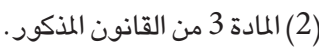

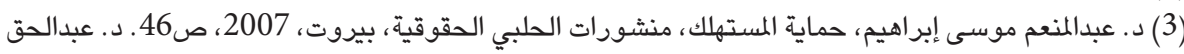
حميش، حماية المستهلك، جامعة الشارقة، 2004، ص54. 


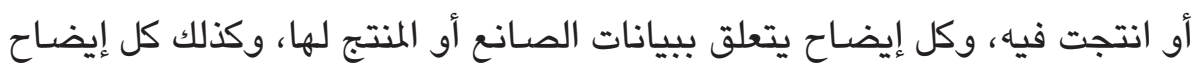

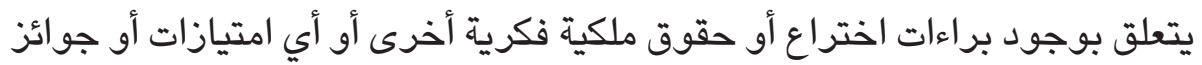

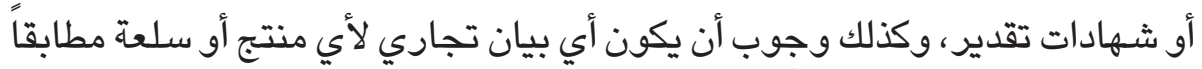

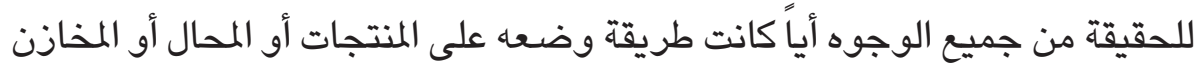

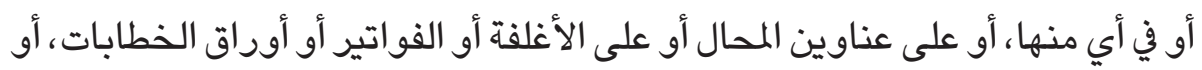

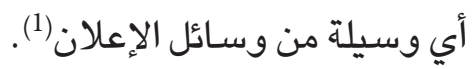

ولا يخفى أن الغرض من ذلك يهدف إلىحسن التنظيم وسهولة الرقابة وموضوعية

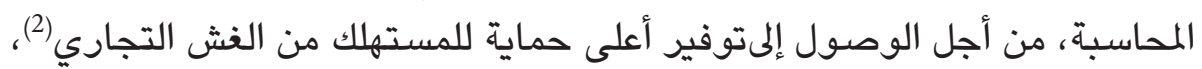

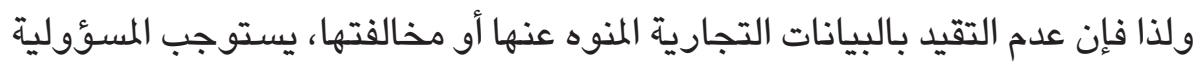
القانونية، وتدخل هذه الأفعال دائرة المنافسة الممنوعة بنص القانون، ولذات الذانك فإنها

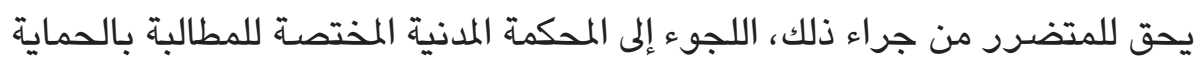

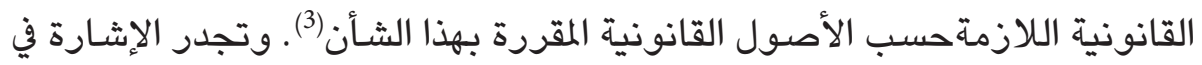

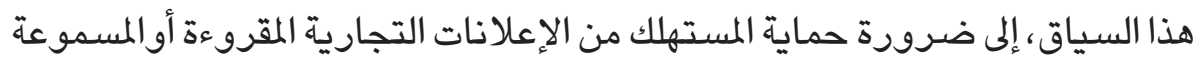

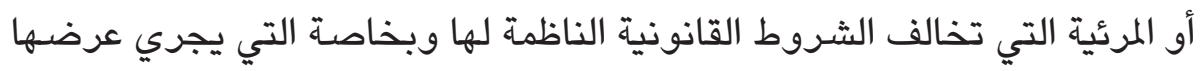

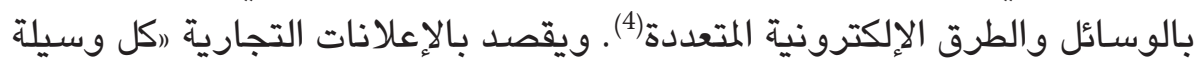

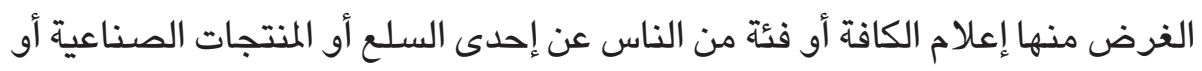

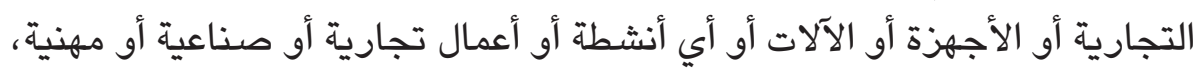

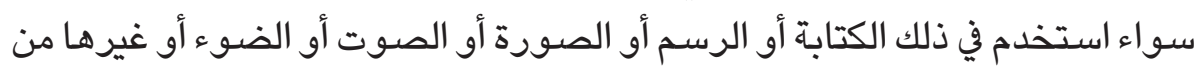

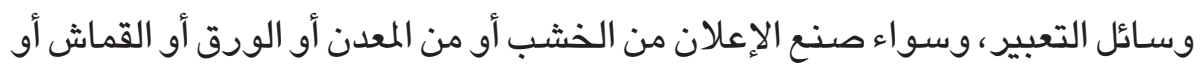

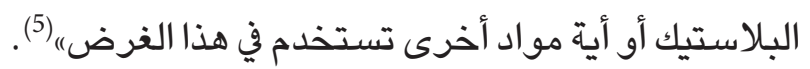

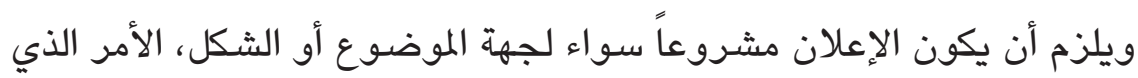

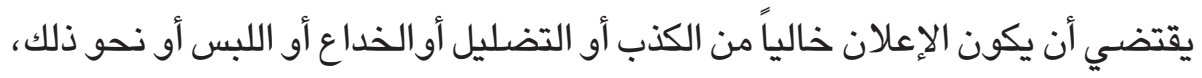

$$
\text { (1) (1) المادتان } 29 \text { و30 من القانون المنكور. }
$$

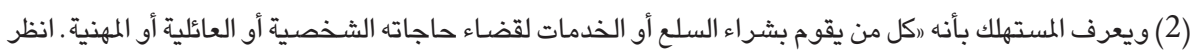

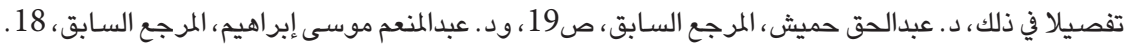

$$
\text { (3) (3) (المادة } 46 \text { من القانون المذكور. }
$$

(4) د. كوثر سعيد عدنان خالد، حماية المستهلك الإلكتروني، دار الجامعة الجديدة، الإسكندرية 2016، 2012، ص173. (5) المادة 1 من القانون رقم (1) لسنة 2012 بتنظيم ومراقبة وضـع الإعلانات القطري. 
ويستوي أن يكون ذلك متعلقاً بالتاجر أو بمتجره أو بما يقدم من منتجات أو سلع

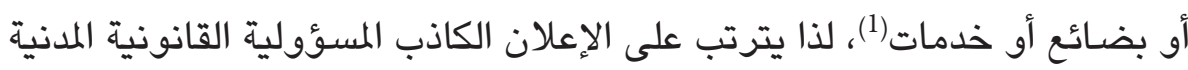

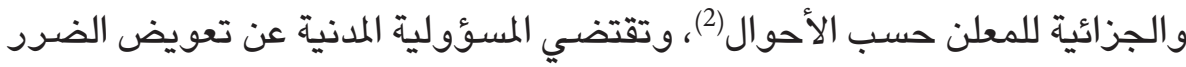

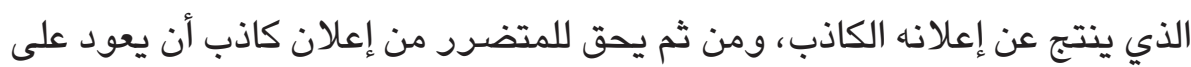

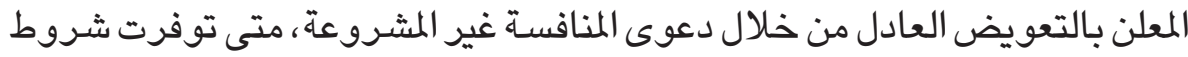
هذه الأخيرة المتمثلة بالخطأ والضرد والعلاقة السببية (3). خامساً - حالة منع الاحتكارات:

تعني المنافسـة التجارية -كما تقدم القول- تزاحم التجار على الزبائن لغرض التها اجتذابهم للسلع التي يتاجرون بها، ويجب على التجار ممارسة المنافسـة التجارية حسب قواعد السوق ومعايير انضباط العمل فيه، وبعيدا عن الممارسات التي تفسد ونس قواعد المنافسة فيه(4)، الأمر الذي يستلزم تقيز الفيد التجار بصحيح العادات والأعراف والقيم والقواعد والأنظمة والقوانين الناظمة لقواعد السوق التجارية (5) لأنه إذا ما تم

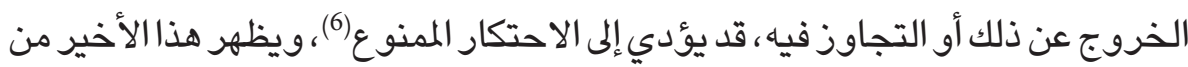

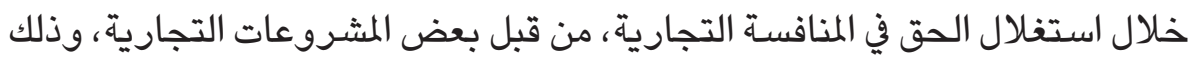

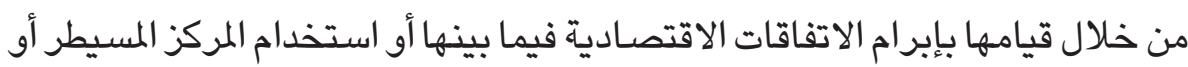

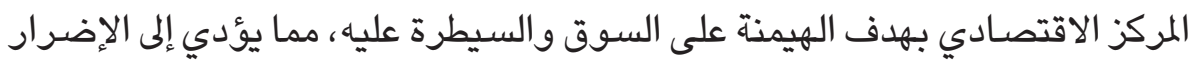

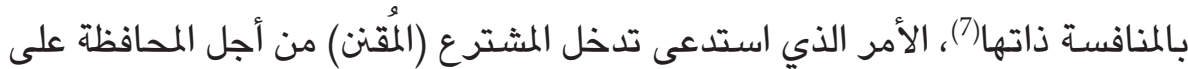
إبقاء المنافسة في حدودها المشروعة ومنع دخولها دائرة الاحتكار (8).

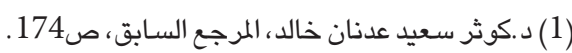

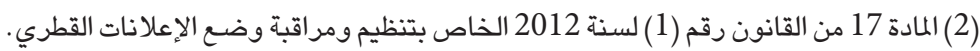
(3) سوف نبحث هذه الشروط في موضع لاحق من هذه الدراسة.

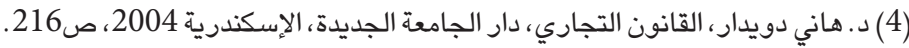

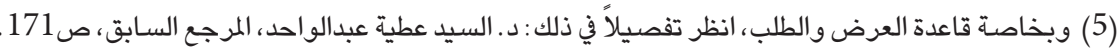

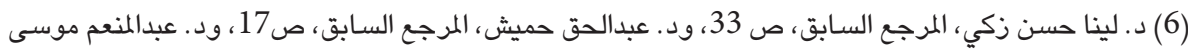

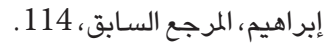

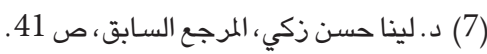

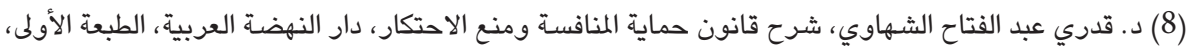

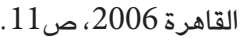


وينظم ذلك في دولة قطر ، قانون حماية المنافسـة ومنع الممارسات الاحتكارية رقم 19

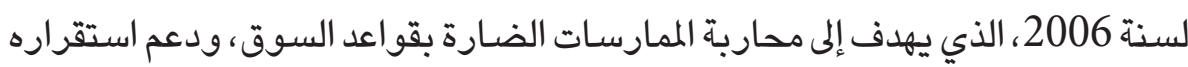

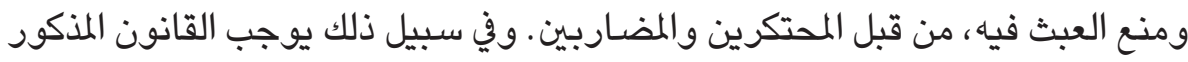

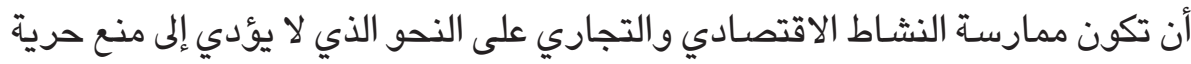

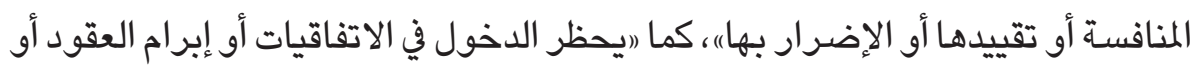

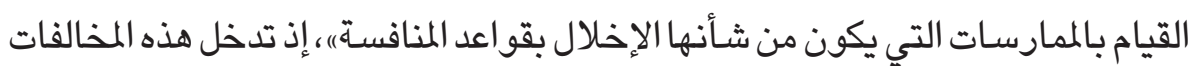

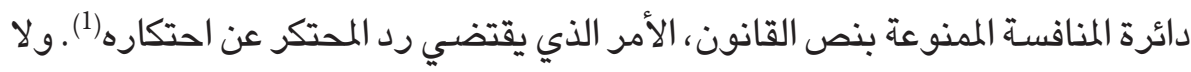

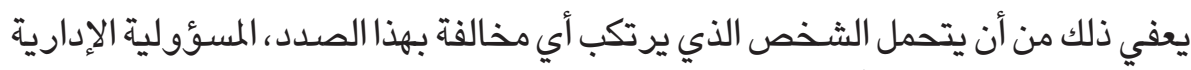

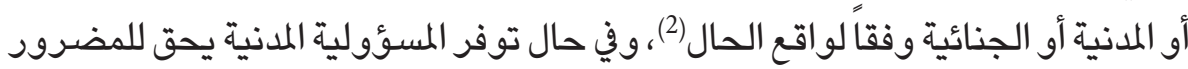

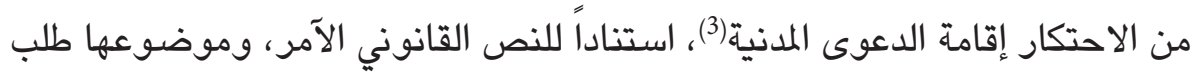

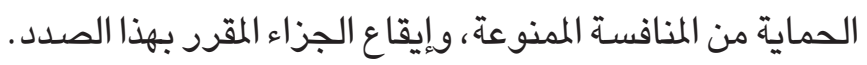

\section{سادساً - حالة الشريك:}

يمنع قانون الشركات القطري رقم11 لسنة الجديد2015(4) كل من يتمتع

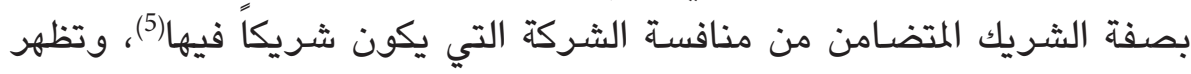

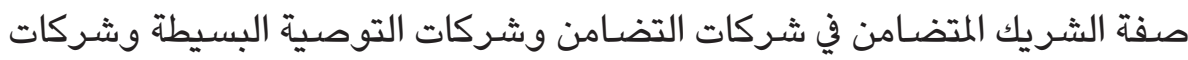

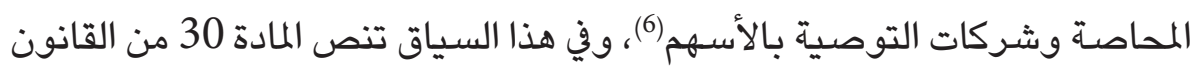
(1) د. محمد سالم أبو الفرج ود ـ المعتصم باله الغرياني، القانون التجاري القطري، دار النهضة القاهرة 2013، ص269.

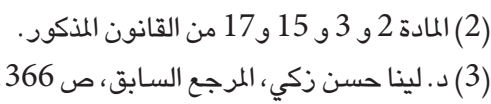

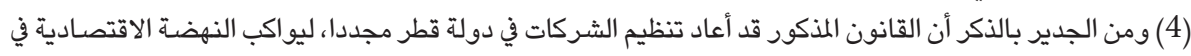

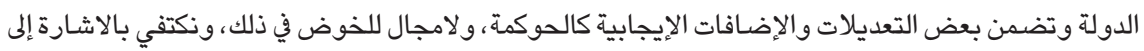

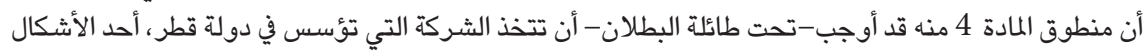

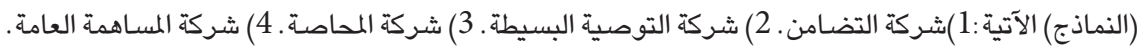

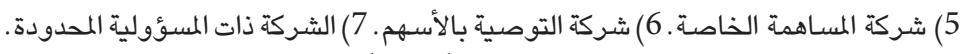

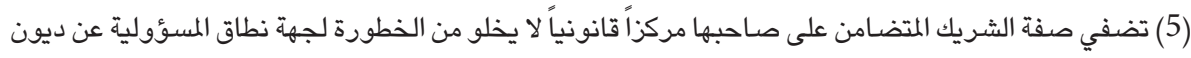

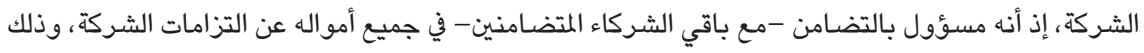

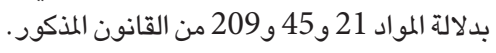

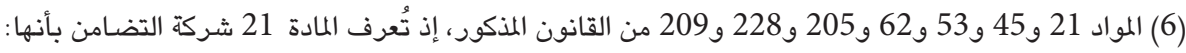

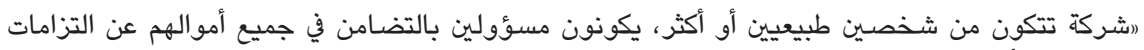

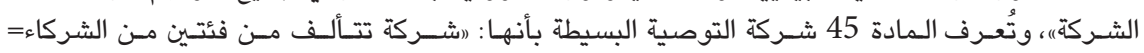


المذكور علىٍ أنه : (الا يجوز للشريك بغير موافقة الشركاء أنِ يمارس لحسـابه أو لحساب

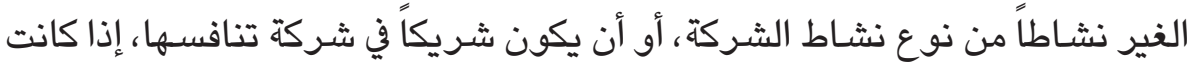

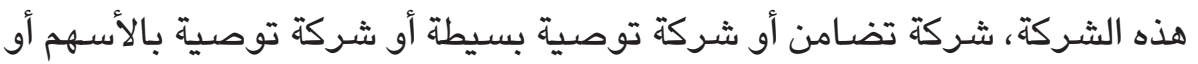

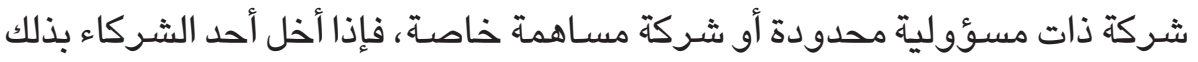

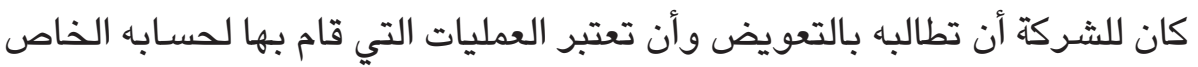

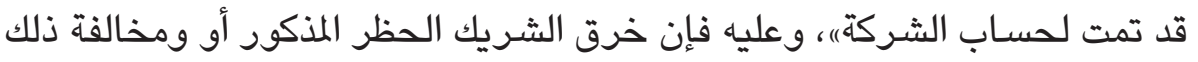

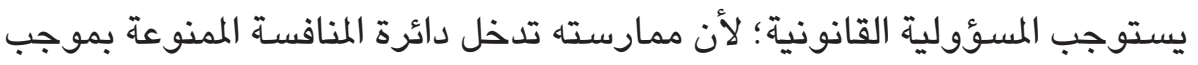

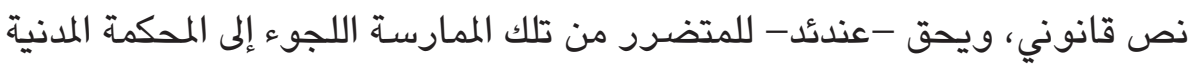

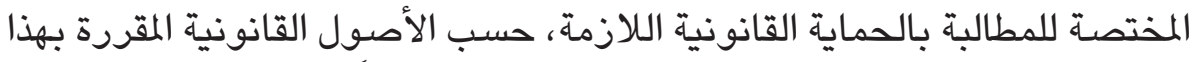

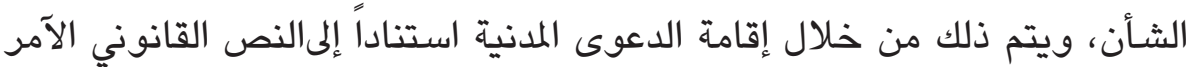

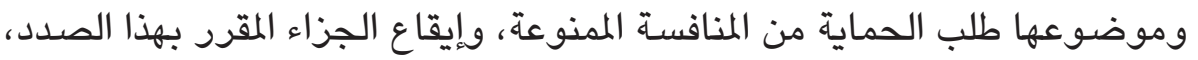

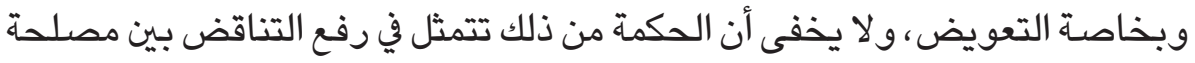

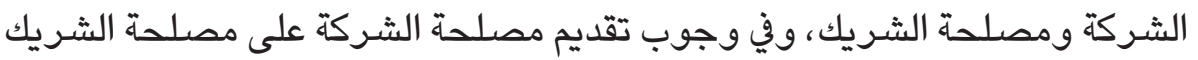

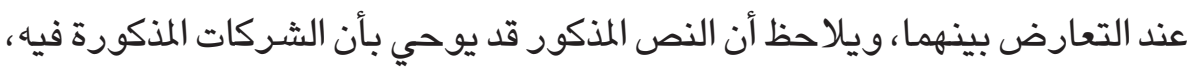

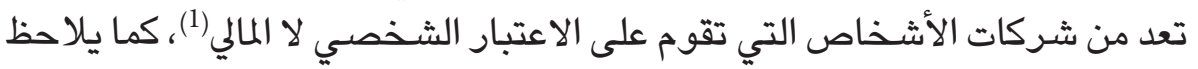

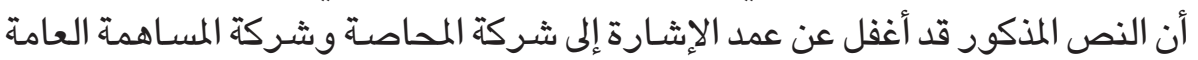

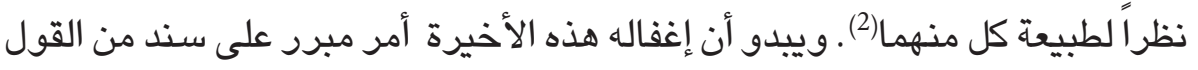

=هما: 1) الشركاء المتضامنون، وهم الذين يديرون الشركة، ويكونون مسؤولين بالتضامن عن جميع التزاماتها

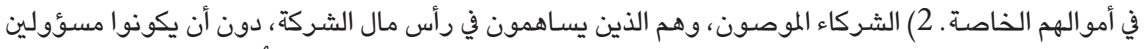

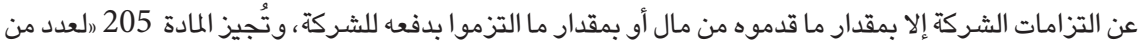

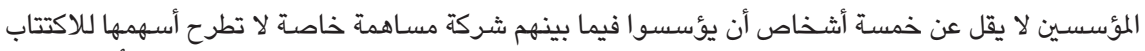

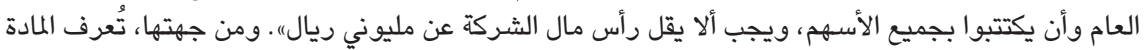

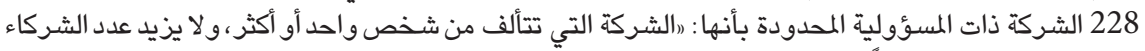

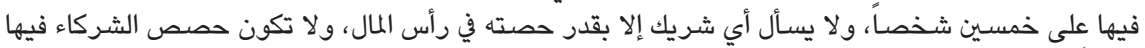

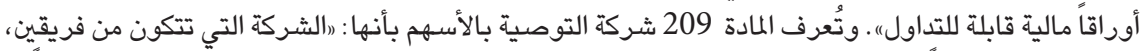

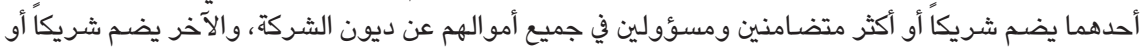

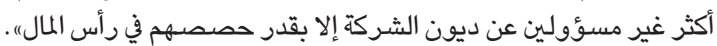
(1) Dr. Mohamed El-Sayed El-Feky, Commercial Law (Commercial Operations-Merchants-

Commercial Companies), Al-Halabi Legal Publications,Beirut,2004. p.357 and 380.

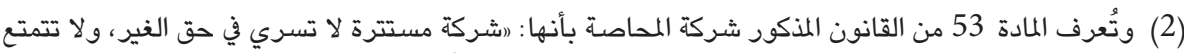

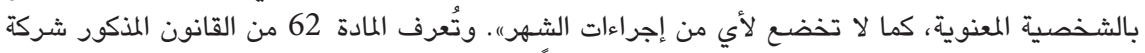

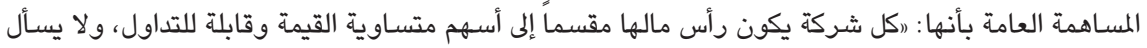
المساهم فيها إلا بقدر مساهمته في رأس المال) . 
بأنها من شـركات الأموال التي تقوم على الاعتبار المالي، أما إغفاله الأولى فليس مبرراً

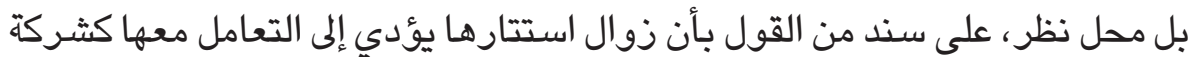

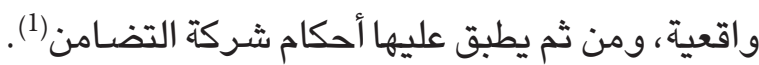

\section{سابعاً - حالة مدير الشركة:}

يحظر قانون الشركات القطري رقم11 لسنة 2015 الجديد على مدير الشركة،

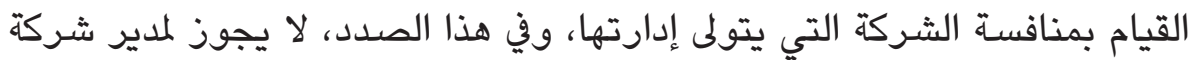

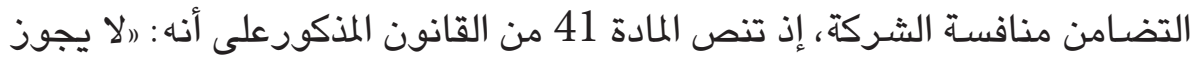

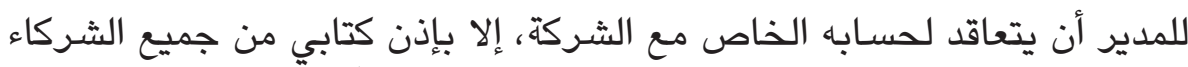

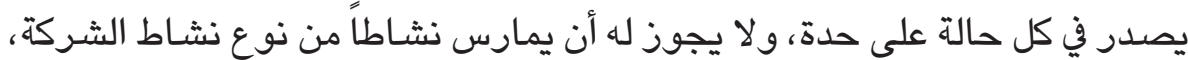

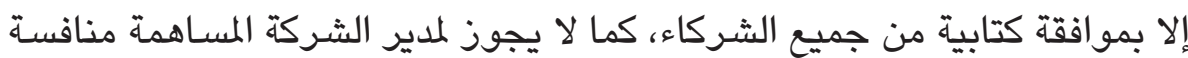

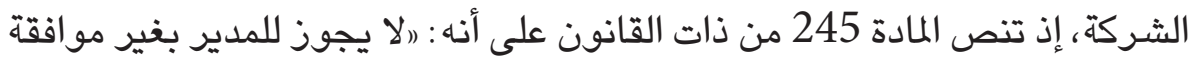

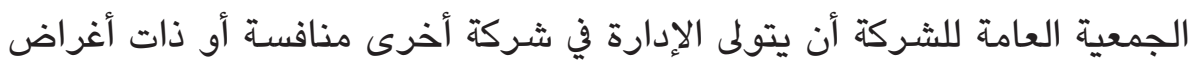

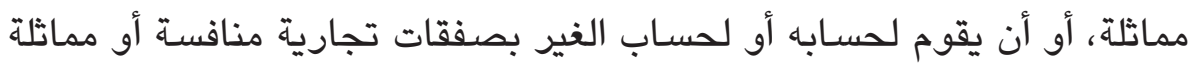
لتجارة الشركة، ويترتب على مخالفة ذلك جواز عزل المدير وإلزامه بالتعويضها . وعليه فإذا قام مدير الشركة بممارسة أي فعل مما ذكر ، ودون أخذ الموافقة كتابة

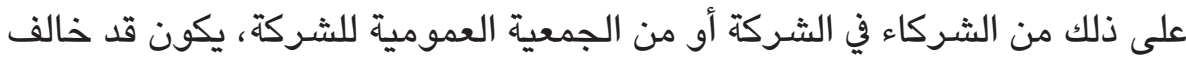

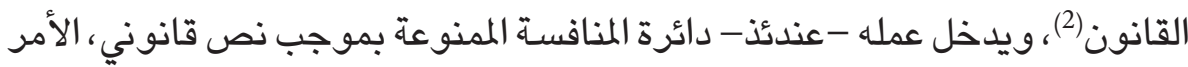

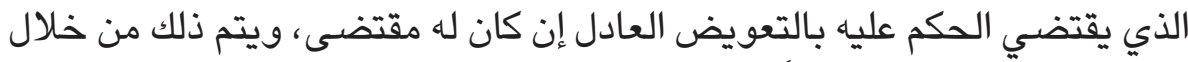

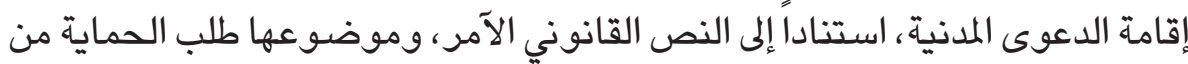

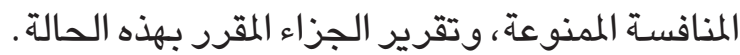

ويلاحظ أن منع مدير الشركة من منافسـة الشركة في النصوص المذكورة هو

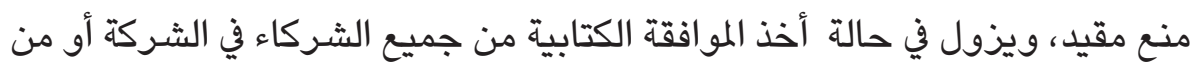

(1) بدلالة المادة 57 من القانون المذكور التي تنص على أنه : (...إذا صدر من الشركاء عمل يكشف للغير عن وجود

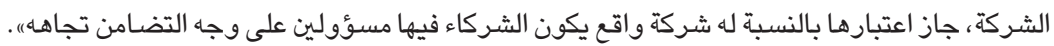
(2) ويسأل المدير عن الضرر الذي يصيب الشركة أو الشركاء أو الغير بسبب مخالفته أحكام عقد الشركة أو أو عقد تعيينه،

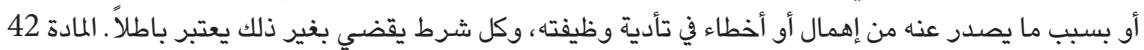


الجمعية العامة للشركة حسب الأحوال، والحكمة من ذلك تتمثل في منع المدير من

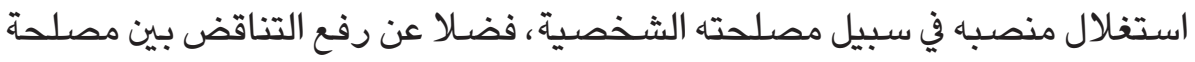
الشركة ومصلحة المدير ووجوب تقديم مصلحة الشركة على مصلحة الشريك عند

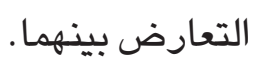

\section{ثامناً - حالة الحظر من ممارسة التجارة:}

يحظر القانون على بعض الأشخاص ممارسة العمل التجاري(1)، وذلك لاعتبارات

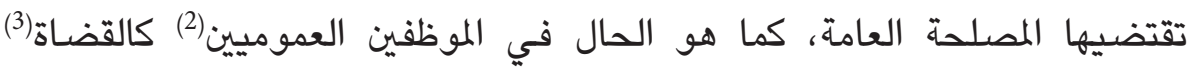
والمحامين(4) ومن يأخذ حكمهم(5)، وذلك لغرض علم التعارض مع مقتضيات المصلحة

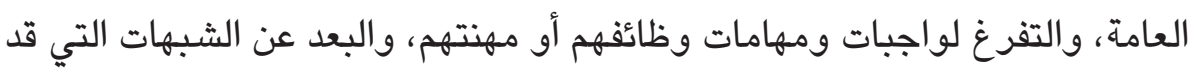

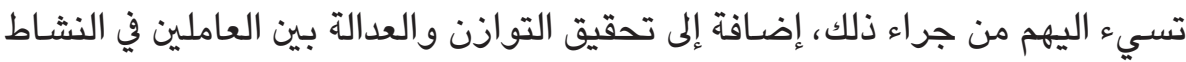

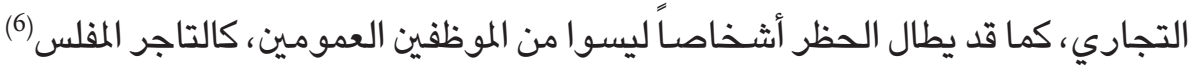
(1) المادة 13 فقرة 3 من قانون التجارة القطري التي تنص على أنه : ه ... وإذا زاول التجارة أحد الأشخاص المحظور

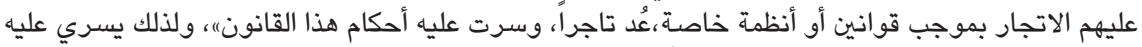

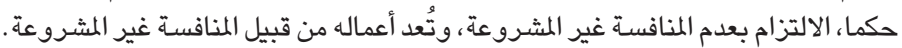

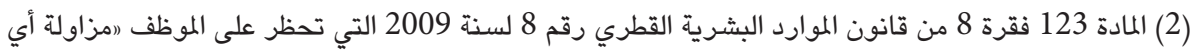

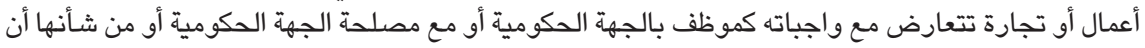

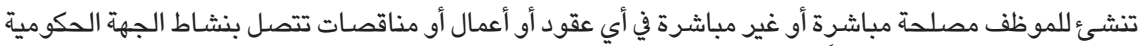

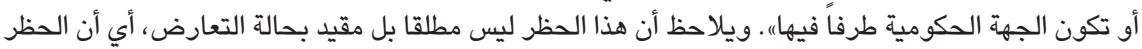

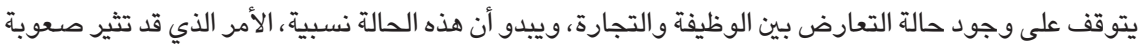

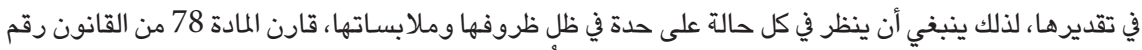

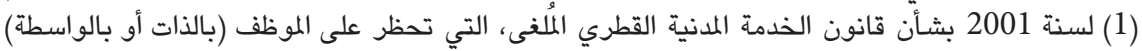
الاشتغال بالتجارة بنفسه أو الدخول بصفة شريك متضامن في شركات التضامن وشركات التوصية البسيطة وشركات التوصية بالأسهـم.

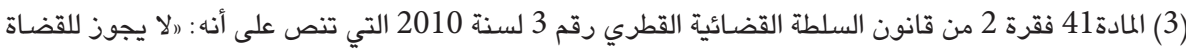

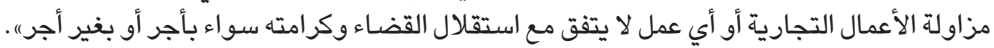

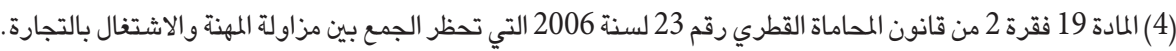

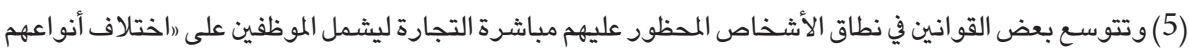

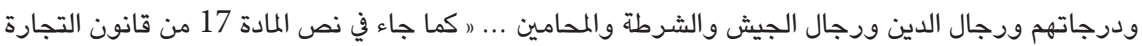

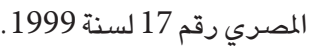

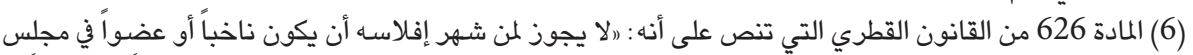

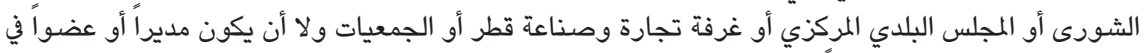

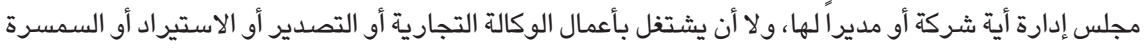

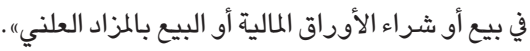


أو من سبق الحكم عليهم في جريمة مخلة بالشرف أو الأمانة(1) لغرض إخراجهم من

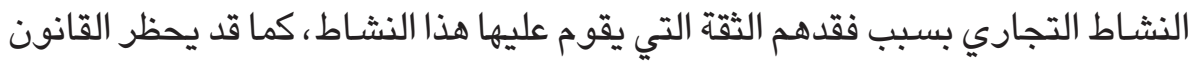

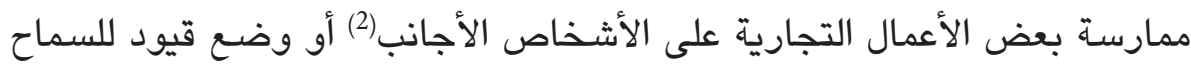

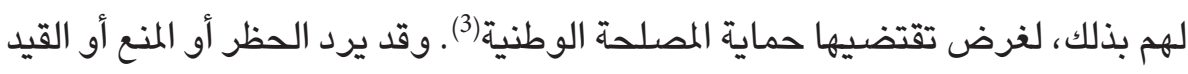

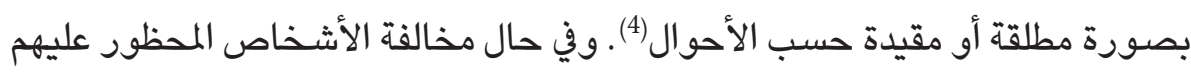

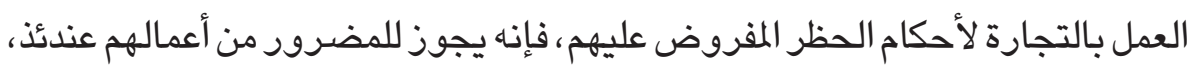
مطالبتهم بالتعويض العادل، ويتم ذلك من خلال إقامة الدعوى المدنية العادية، استناداً

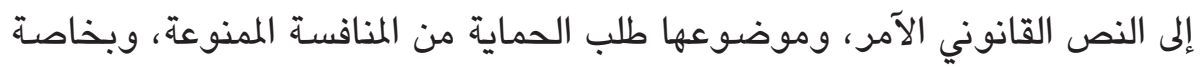

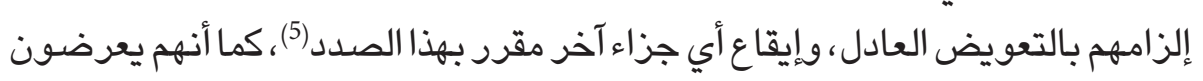

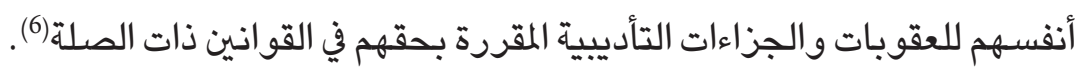
ويتضح لنا مما سبق أن الحالات المذكورة تُشكل نماذجاً من صور المنافسة

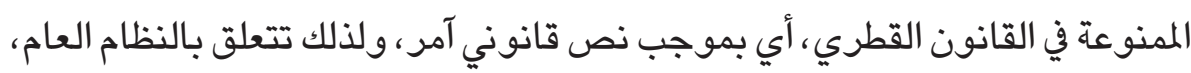

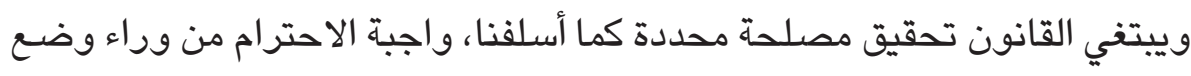

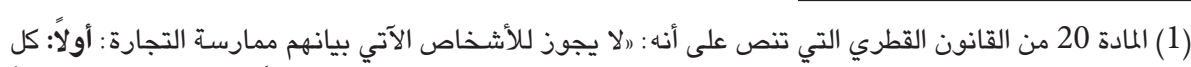

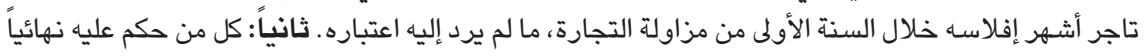

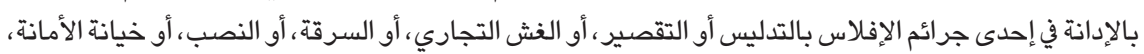

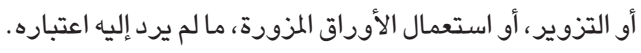

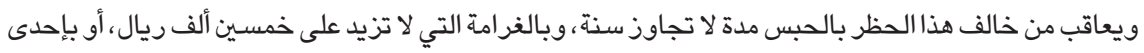

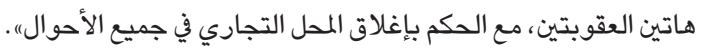

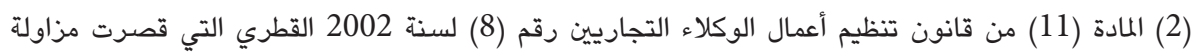

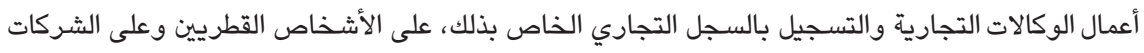

$$
\text { التي يكون كل رأس مالها قطريا. }
$$

(3) المادة 61 من قانون الشركات القطري الجديد رقم 11 لسنة 2015 التي تنص على على أنه : رإذا كان بين الشركاء

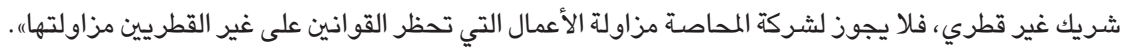

(4) Dr. Kameran Al-Salihi, Abdulla Hassan, Principles of Business Law, Alfalah Books, first Edition, Dubai, 2013. p.27.

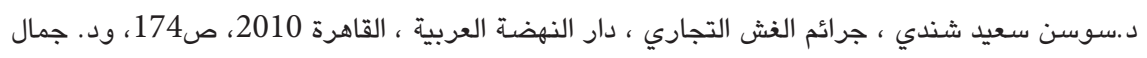

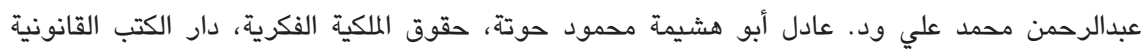

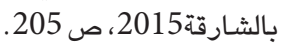

(6) كالجزاءات التأديية التي ينص عليها قانون السلطة القضائية وقانون المحاماة وقانون الخدمة البشرية، وقد سبقت الإثـارة إلى هذه القواتين. 
الأحكام القانونية الخاصـة بتلك الحالات، ولذلك لا يجوزخرق الأحكام القانونية لأي

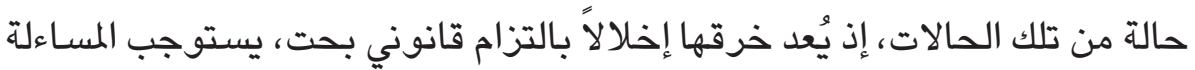

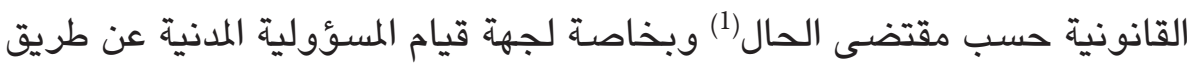

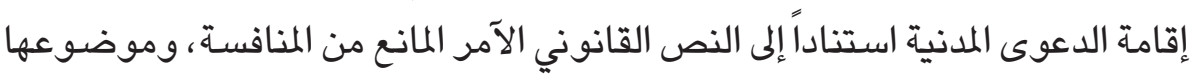
طلب الحماية من المنافستة الممنوعة، وإيقاع الجزاء المقتضى بشأنسأن ذلك.

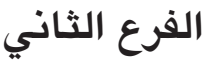

\section{المنافسة غير المشروعة والمنافسة الممنوعة بمقتضى العقد}

تَعني المنافسـة غير المشروعة- كما رأينا- خروج التجار لدى ممارستهم نشـاطهم

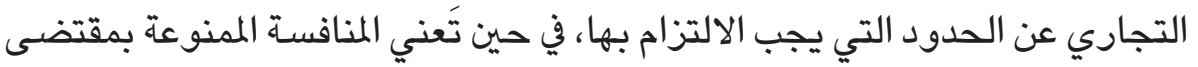
العقد خروج المتعاقد عن شروط التعاقد (2).

ويطلق على المنافسة الممنوعة بمقتصى العقد، أكثر من تسمية، ومنها „الحماية

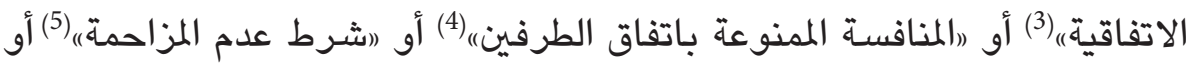

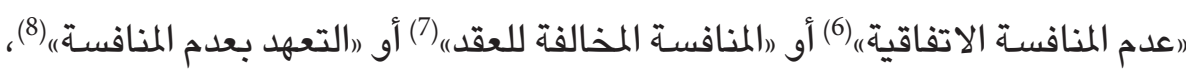
ولا يوجد -في الواقع - أي فرق بين هذه التسميات، لأن جميعها تدل على نفس المسمى المئ.

(1) د. سوسن سعيد شندي، المرجع السابق، ص174 ـ د. جمال عبدالرحمن علي ود. عادل أبو هشيمة محمود حوتة،

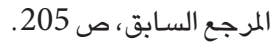

(2) ذلك أن العقد شريعة المتعاقدين حال اكتمال أركانه وشروطه بالتمام والكمال، ويلزم تنفيذه بحسن نية تامة، الأمر

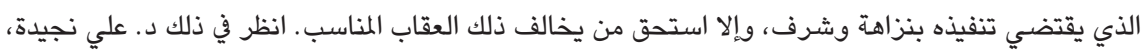

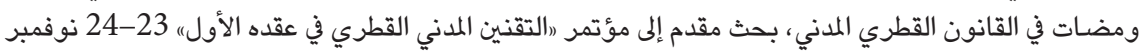

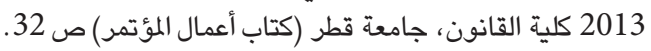

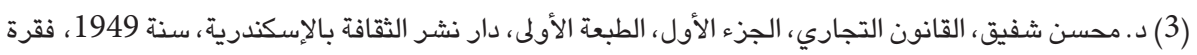

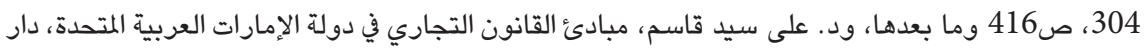

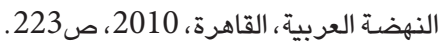

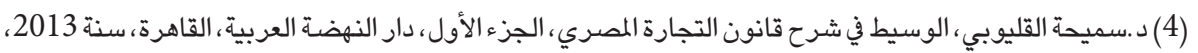

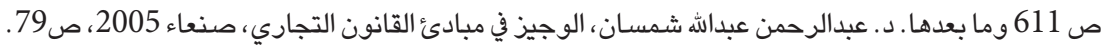

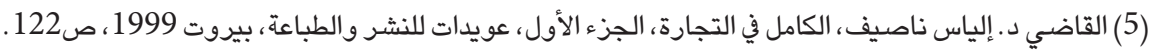

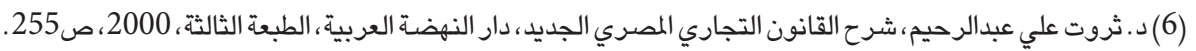

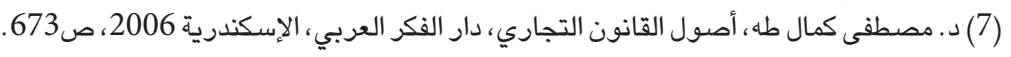

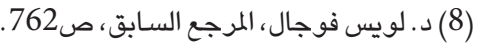


وتأخذ المنافسـة الممنوعة بمقتضى العقد أكثر من صورة، فقد ترد في عقد إجارة موقع

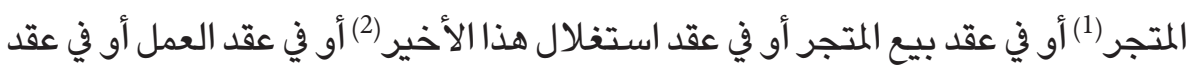

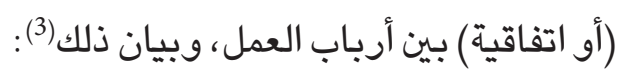

أولاً - عدم المنافسة التجارية بموجب شرط في عقد بين المنتجين أنفسهم:

قد يتفق منتجو سلع معينة على تنظيم إنتاج تلك السلع فيما بينهم، لجهة الكمية

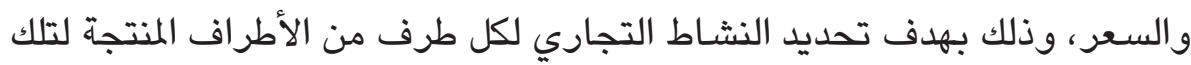

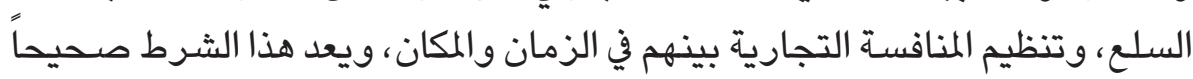

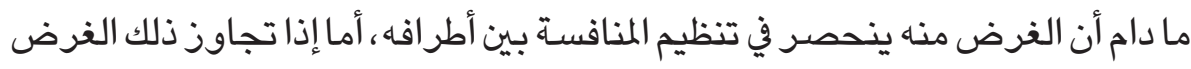

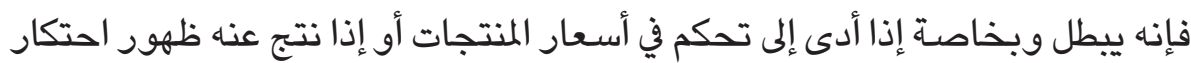
لتلك المنتجات(4). وفي هذا السياق، فإن القانون رقم 19 لسنة 2006 بشأن إلن حماية

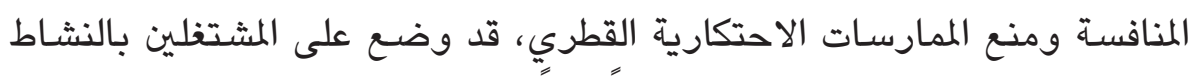

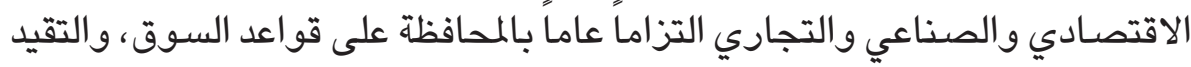

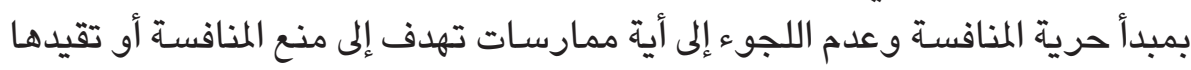

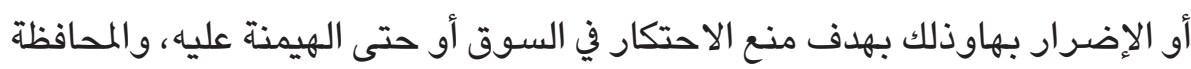
على قواعد المنافسة التجارية، والبعد عن التعسف في استعمال حق المنافسـة. وفي سبيل تحقيق ذلك يحظر القانون المذكور الاتفاقيات التي تبرم بين التجار

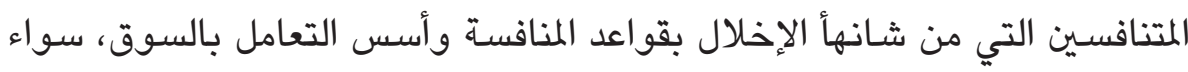

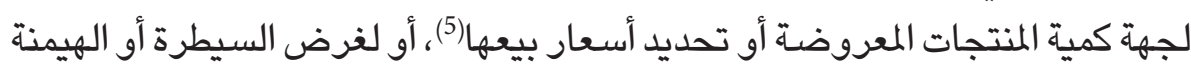

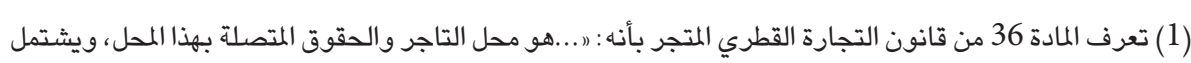

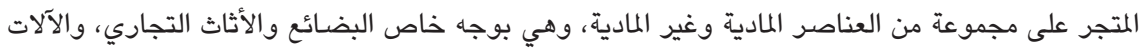

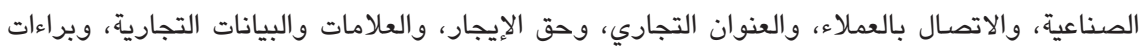

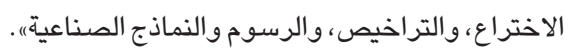

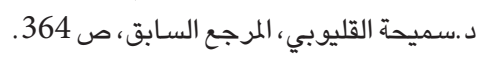

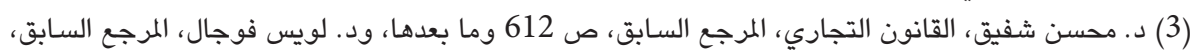

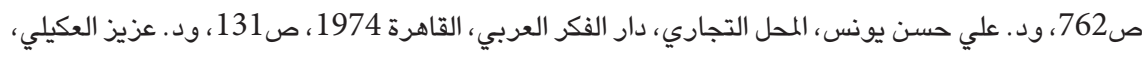

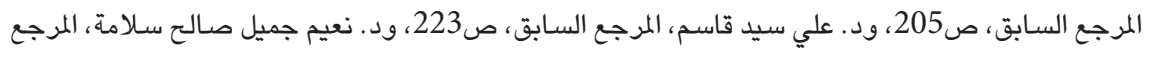

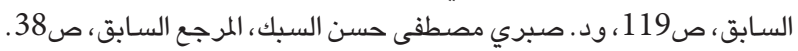

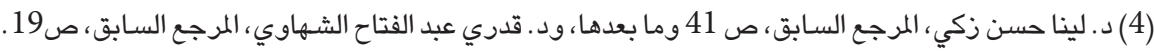
(5) (5) المادة 3 من القانون المذكور. 
على سلعة بعينها أو سوق بذاته في مكان معين أو زمان محدد، أو غير ذلك من الأفعال

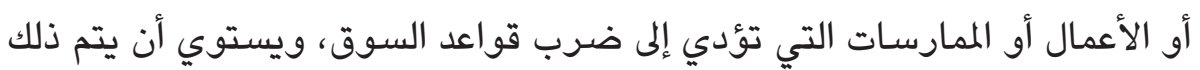

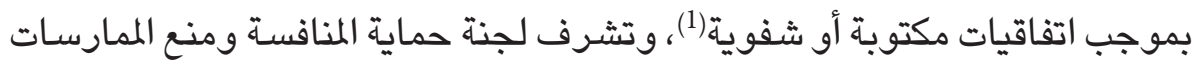

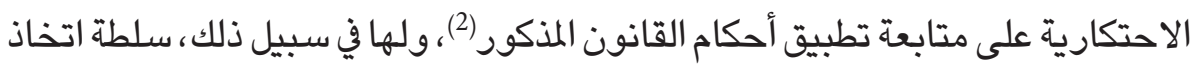

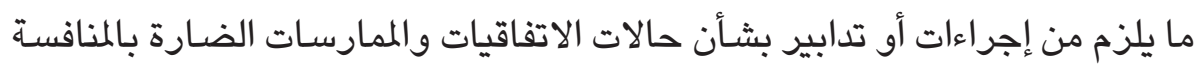

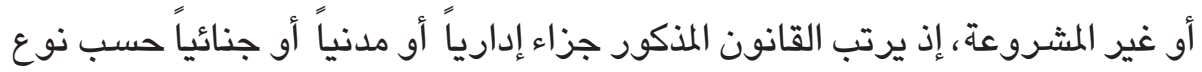

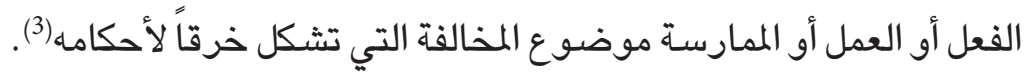
ثانياً - عدم المنافسة التجارية بموجب شرط في عقد أو اتفاق بين المنتج والتاجر: يوجد وجهان لهذه الصورة من صور عدم المنافسة التجارية بموجب الاتفاق: 1 - أن يشترط التاجر مشتري السلعة على المصنع المنتج لها عدم بيع ذات السلعة لغيره من التجار (حالة الوكيل الحصري لجهة التاجر المشتري). 2- أن يشترط منتج السلعة على التاجر المشتري لها عدم شراء ذات السلعة من غيرة من المنتجين (حالة الوكيل الحصري لجهة المنتج البائع).

ويطلق على هذه الشروط شروط القصر (4)، ويثير هذا النوع من الشروط بعض فـ

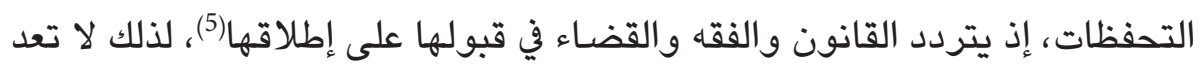

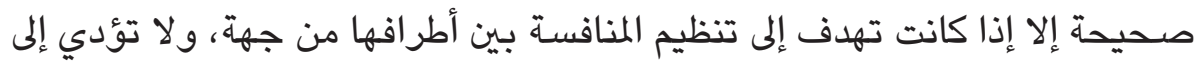

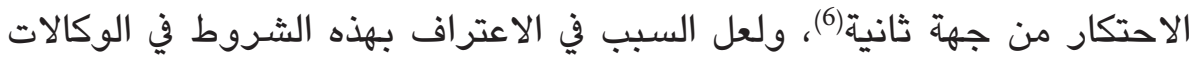

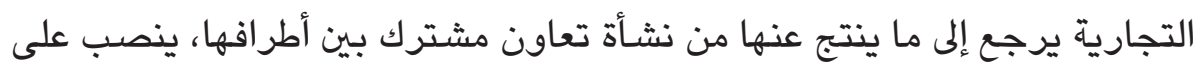

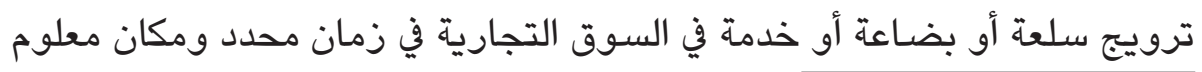

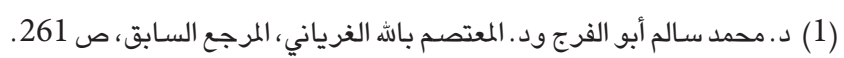

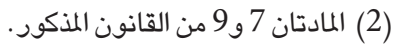

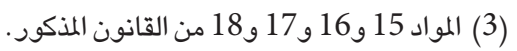

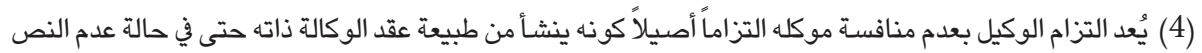

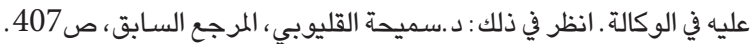

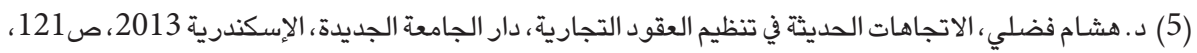

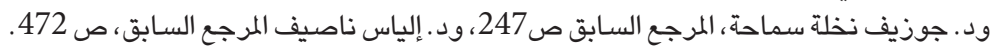

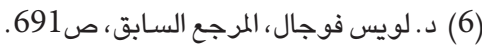


على زبائن متوقعين، يتحمل الموكل العبء الأكبر في إنجاح ذلك، وبخاصـة في المرحلة

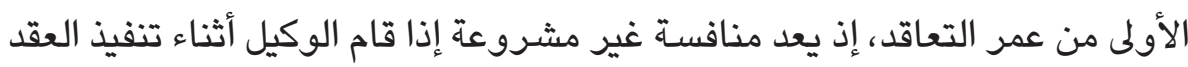

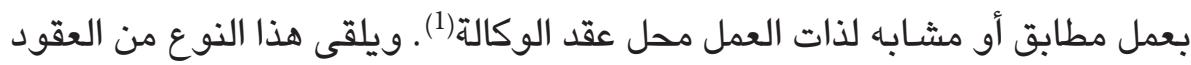

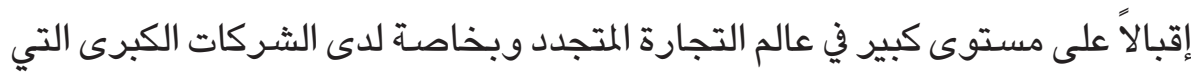

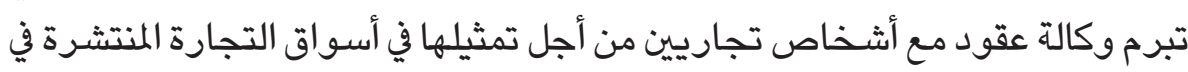
أنحاء المعمورة، ويظهر ذلك بجلاء في العديد من دول مجلس التعاون الخليجي (2) كونها

منطقة جاذبة للاستثمار (3).

وينظم القانون القطري هذا النوع من العقود لأهميتها القانونية والعملية في النشـاط

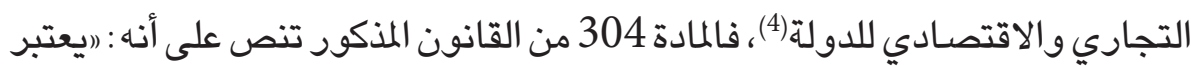

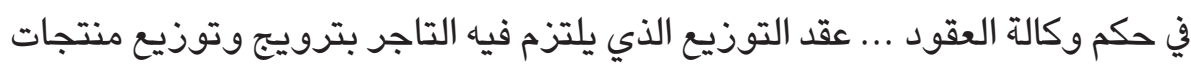

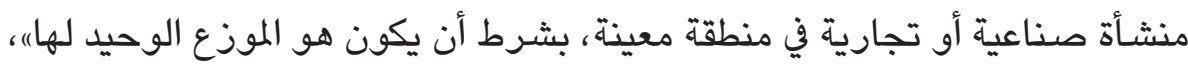

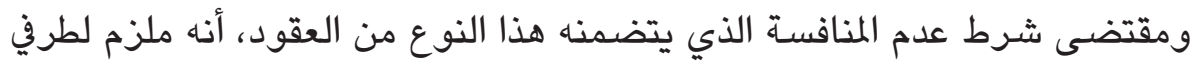
العقد، والإخلال بها يستوجب التعويض العادل لجبر الضرر الناتج عن ذلك، لأن وكالة

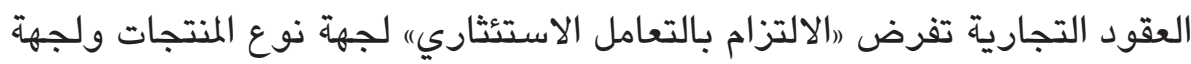
منطقة جغرافية محددة أو لجهة منع الغير من منافسته في ذلك(5)، فإذا قام الوكيل

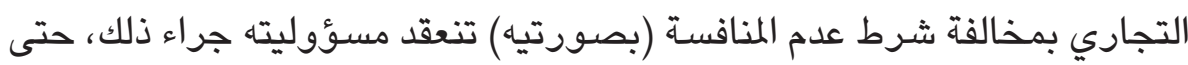
ولو لم يكن هو الوكيل الوحيد الحصري في صدد ذلك.

ويلاحظ أن شرط عدم المنافسـة شرط دارج في نطاق العقود التجارية على اختلاف

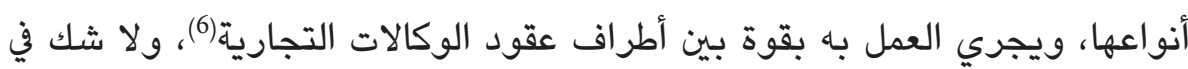
(1) د.سميحة القليوبي، المرجع السابق، ص405، ود . علي سيد قاسم، المرجع السابق، ص223، ود. نعيم جميل (2) Dr. Mosleh A. At'tarawneh, Principles Of Commercial Law, Dar Qatari Bin Al-Fuja'a, Qatar, 2007, p. 291. Dr.kameran Al-Salihi, Abdulla Hassan, ibid, p.119.

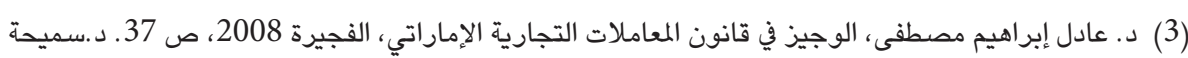

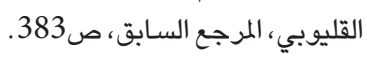

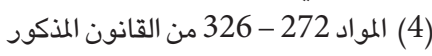

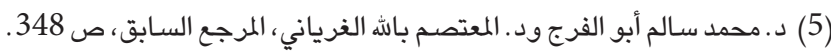

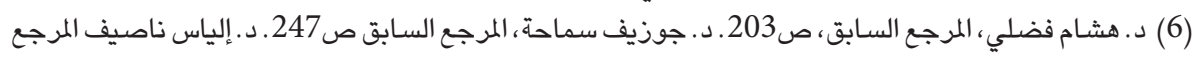

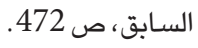


قانونية هذا الشرط متى كان محدداً لجهة نوع التجارة محل شرط المنع من المنافسـة،

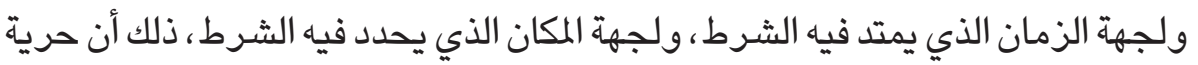

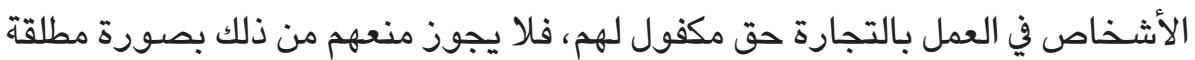
أو عامة أو دائمة، كما يلاحظ أن سريان التزام عدم المنافسـة يكون طول مدة العقد المبرم بين الطرفين، كما يستمر لمدة معينة (سنة أو سنتين على الأقل) من بعد انتهائه أيضـاً.

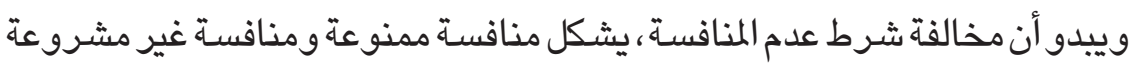

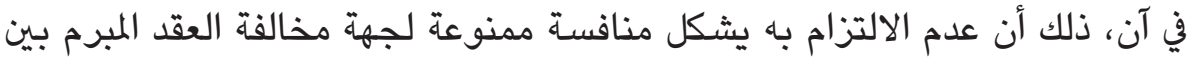

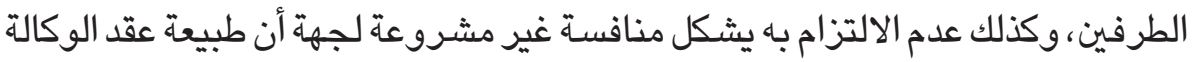

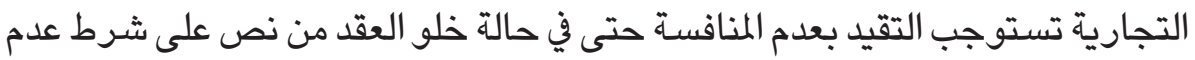

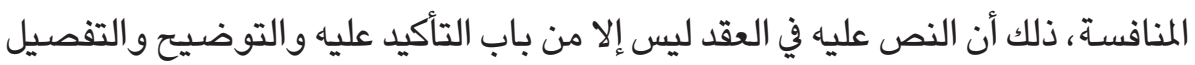

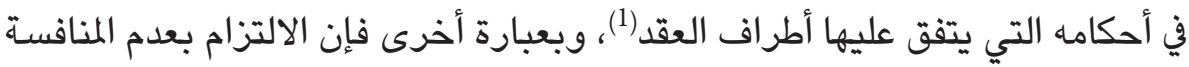
في الوكالات التجارية يكفلها القانون حتى من غير النص على ذلك في العقد ذاته(2)، وفي

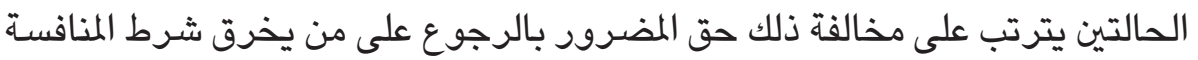

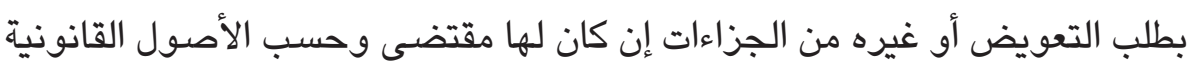

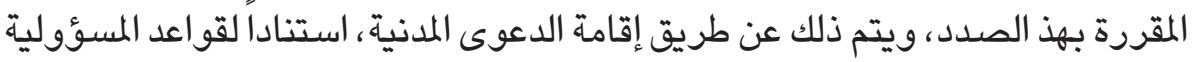

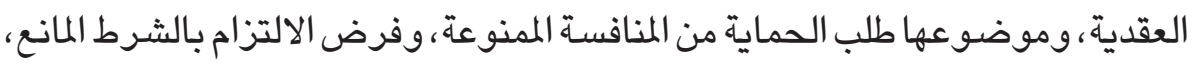
وكذلك إيقاع الجزاء المقرر على مخالفة أحكام ذلك الشرط.

ثالثاً - عدم المنافسة التجارية بموجب شرط في عقد إيجار موقع المتجر: يحق لمالك العقار التجاري تأجيره لمن يشـاء من التجار لممارسـة النشـاط التجاري الذي يروق لهم (3)، ومع ذلك فقد يشترط أول مستأجر على مالك العقار في عقد الإيجار

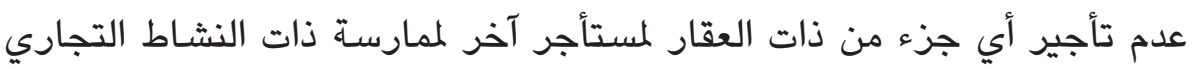

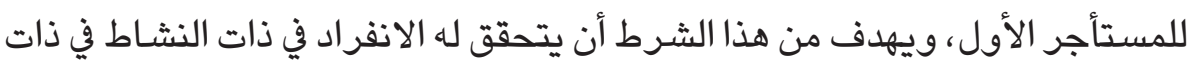

$$
\text { (2) (1) د. هـمـام فضلي، المليوبي، المرجع السـابق، ص203. }
$$

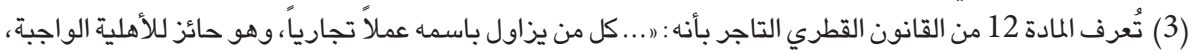

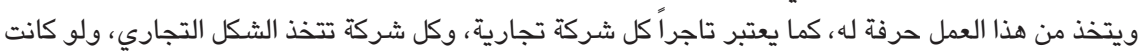

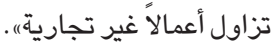


العقار، وتجنب منافسته من مستأجر آخر على الزبائن في ذلك العقار والدائرة المكانية المحيطة بذلك.

ويلاحظ أنه يتم وضع هذا الشرط مبكراً في عقد الإيجار من قبل مستأجر العقار لدى بدء نشاطه التجاري في المتجر المستأجر ، ويحقق له هذا الشرط الاستباق لحماية

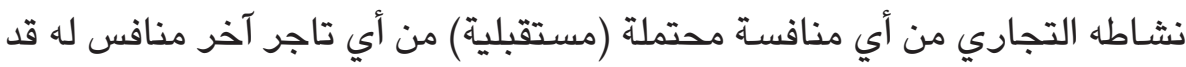

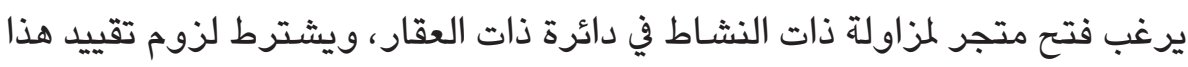

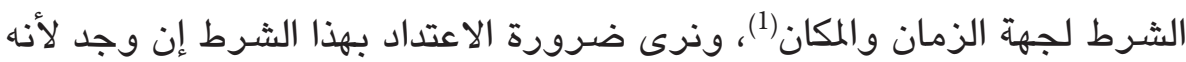

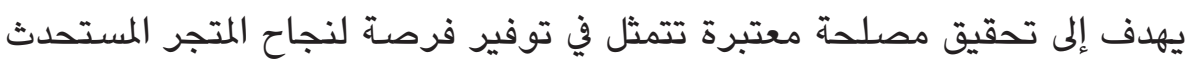
الذي يتطلب انفاق أموال خلال عملية التأسيس كبدل الإيجار والديكورات والدعاية وما يلزم لاستقطاب الزبائن.

ومقتضى هذا الشرط -حال وجوده- أن يتم التزام المؤجر بالشرط المذكور،

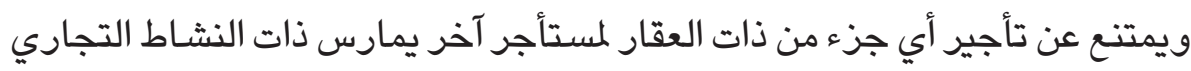

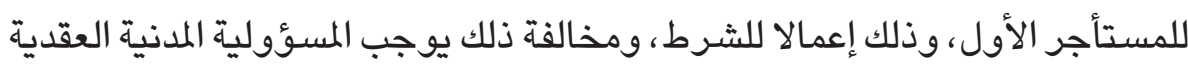

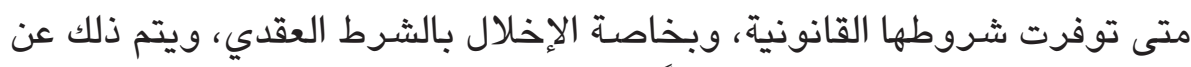

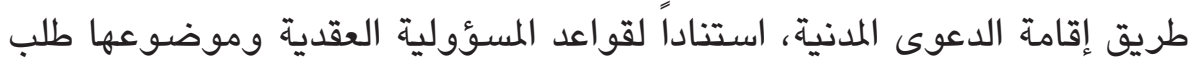

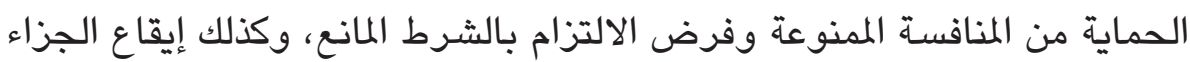

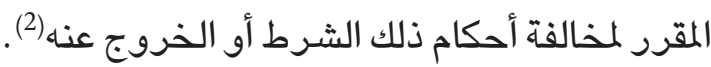

\section{رابعاً - عدم المنافسة التجارية بموجب آثار عقد بيع المتجر:}

تعد التجارة -كما سلف البيان- من أكثر المهن الحرة انتشـاراً في المجتمعات، ومن

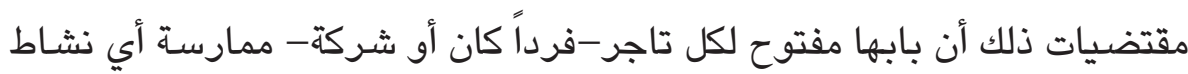

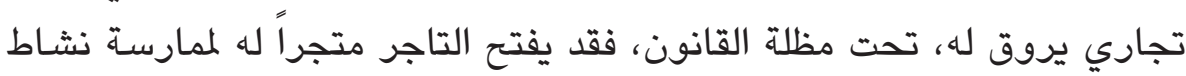
تجاري معين ومن ثم يقوم ببيعه بعد ذلك إلى تاجر آخر ، ثم يعود من جديد إلى ممارسة فئس

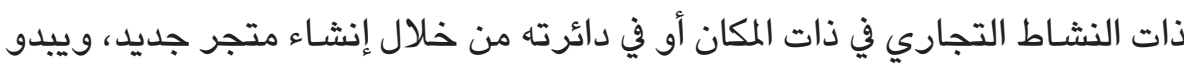

$$
\text { (1) (1) د. صبري مصطفى حسن السبك، المرجع السابق، ص39. }
$$

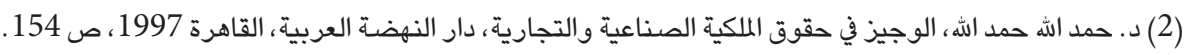

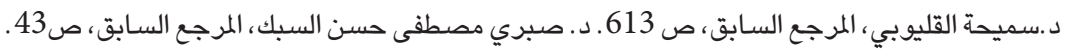


أن هذا التصرف لا غبار عليه في الوهلة الأولى، لانسجامه مع حرية التجارة، وفي الواتع

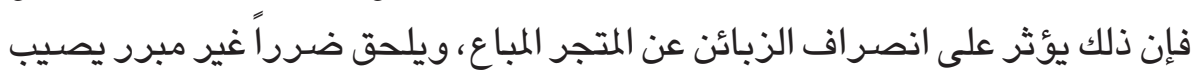

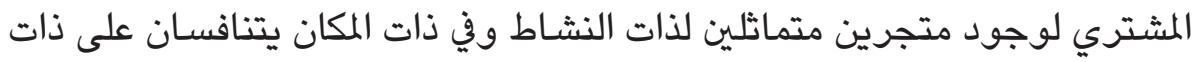

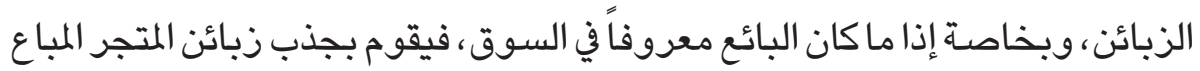

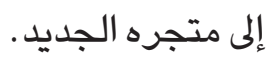

ومن أجل معالجة هذه الحالة أو دفع ضررها عن مشتري المتجر، كان لازما أن

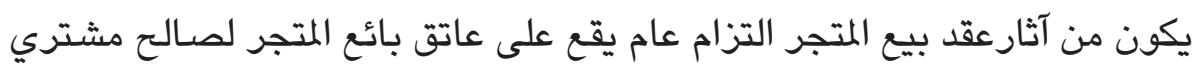

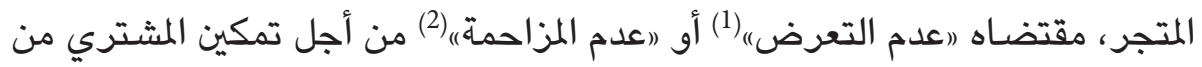

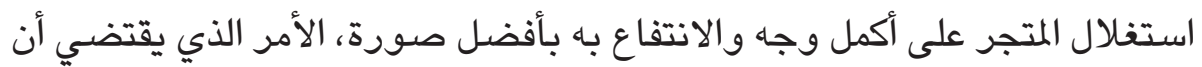

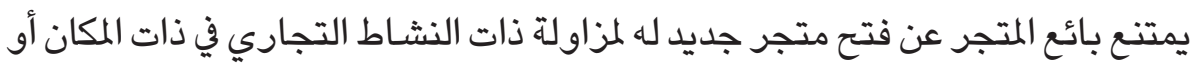

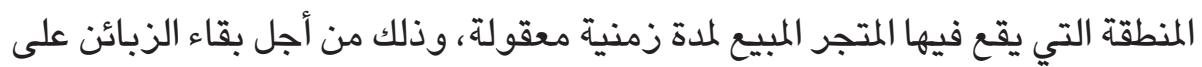

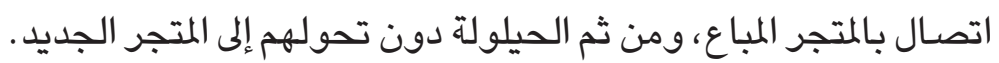

ويقر القانون والفقه والقضـاء ترتيب هذا الالتزام على البائع لصالح المشتري،

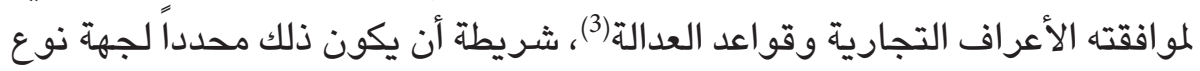

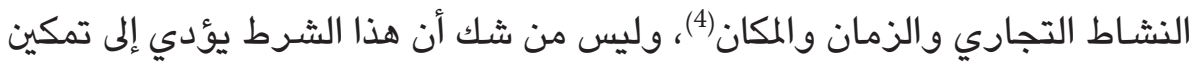

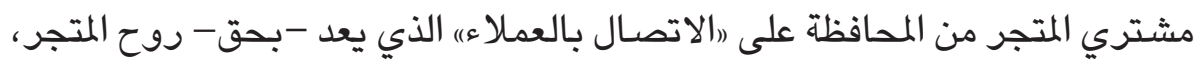
ويؤثر بقوة في تقدير ثمنه .

وينظم القانون القطري بيع المتجر في المواد 39-45 منه، ويلاحظ أن المواد

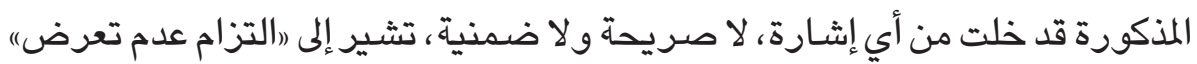

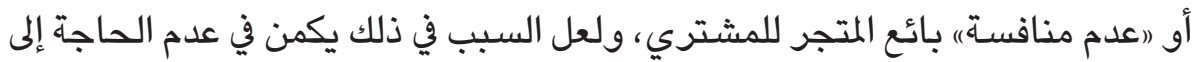

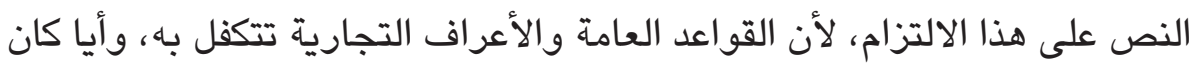

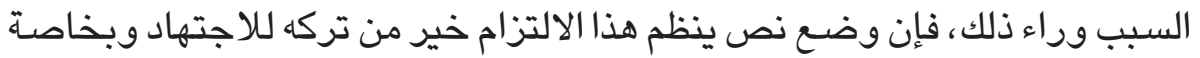

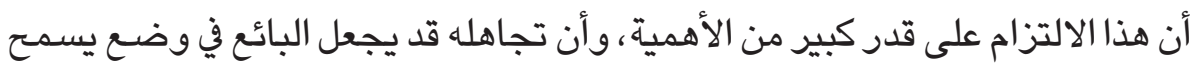

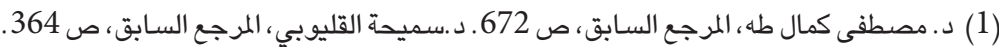

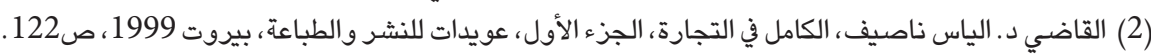

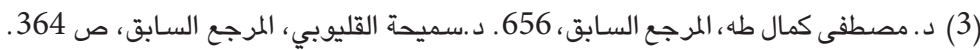

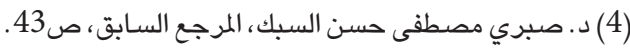


له بالمناورة في تنفيذه والتقيد به لغياب النص القانوني الصريح عليه، الأمر الذي يلحق

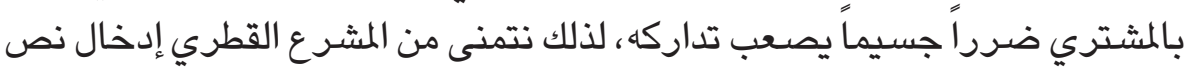
يقنن فيه هذا الالتزام المهم كأثر من آثار عقد بيع المتجر (1). وفي حالة عدم احترام هذا الآثر للعقد، يحق للمضرور من ذلك مقاضـاة المخالف

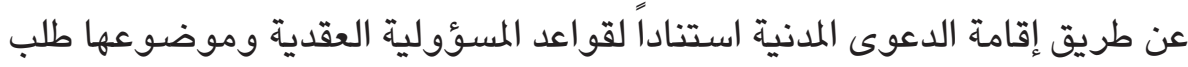

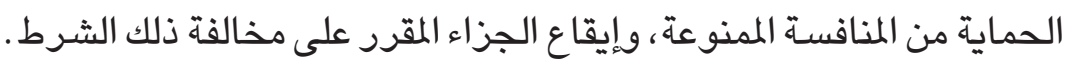

خامساً - عدم المنافسة التجاريـة بموجب شرط خاص في عقد بيع المتجر:

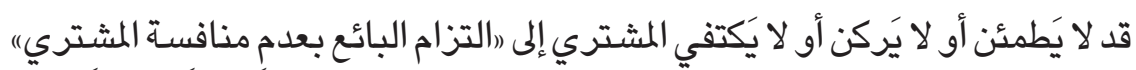

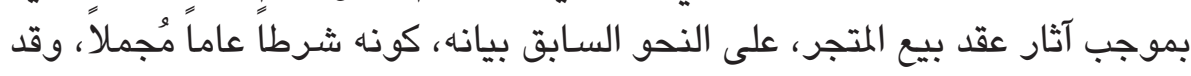

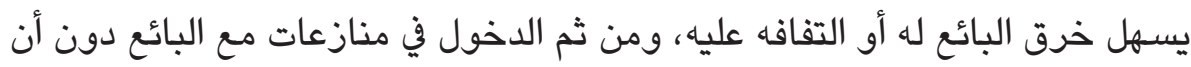

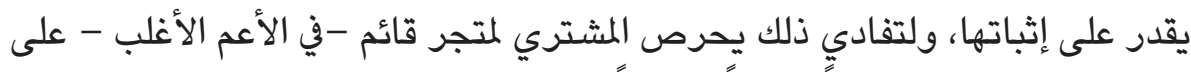

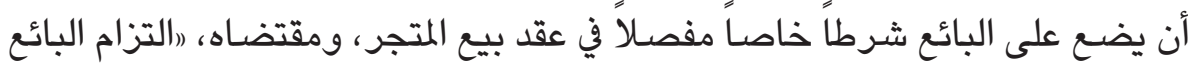

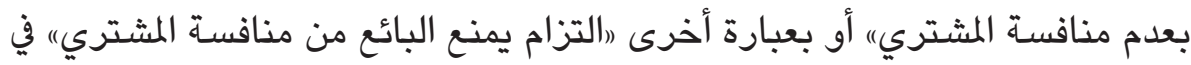

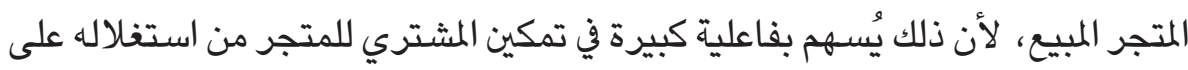

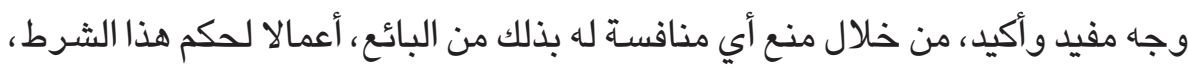

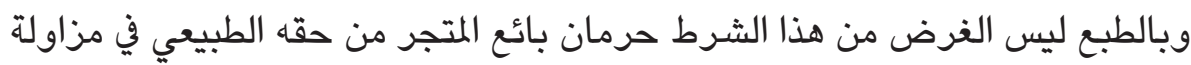

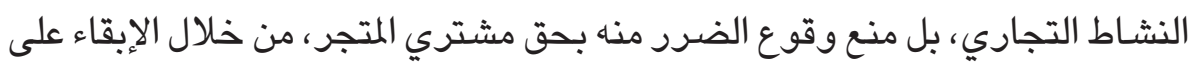
الاتصـال بالعملاء أو الزبائن والاحتفاظ بههم، ومنع منافسـة البائع له في ذلك.

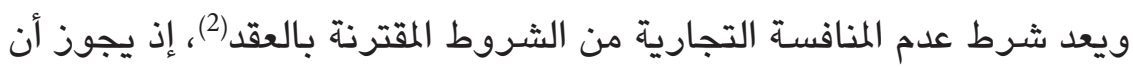

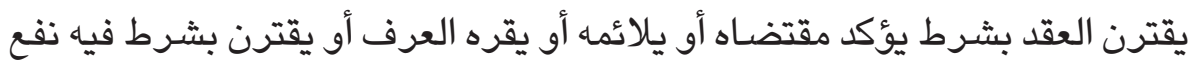

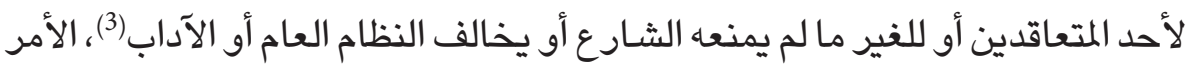

(1) يلاحظ أن بعض القوانين قد قننت هذا الالتزام، فعلى سبيل المثال نجد أن المادة 42 من قانون التجارة رقم 17 لسنة

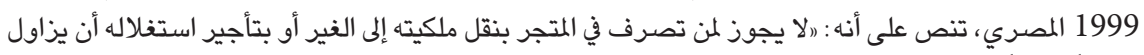

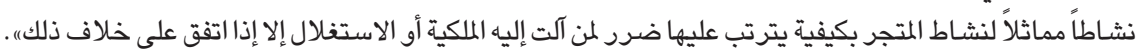

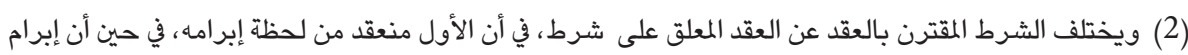

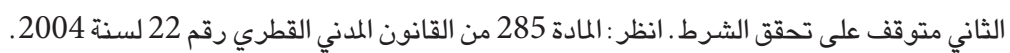

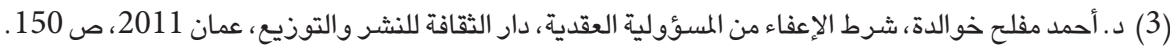


الذي يمكن معه القول أنه لا يوجد في القانون القطري ما يمنع من وضـع هذا الشرط،

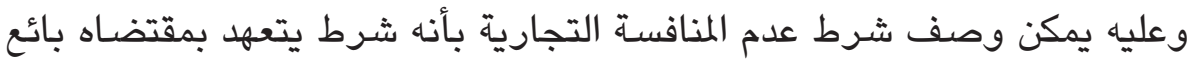

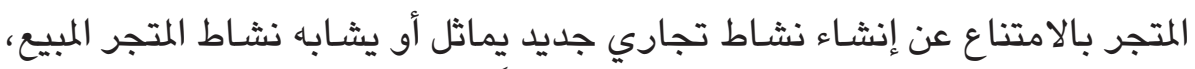

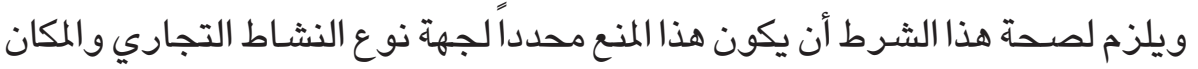
والزمان، الأمر الذي يقتضي أن يتم وضـع هذا الشرط بصورة هذرة صريحة ومفصلة

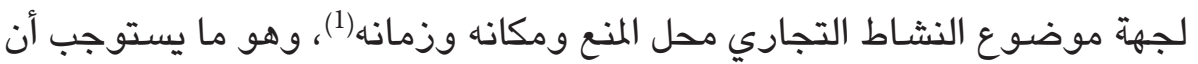

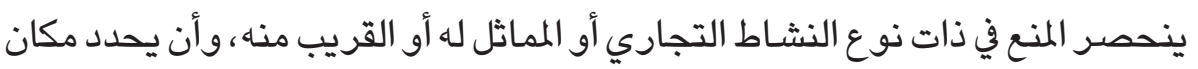

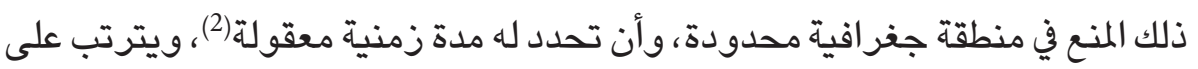

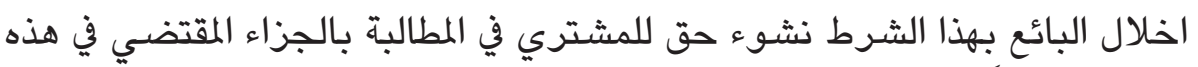
الحالة مستتداً في ذلك إلىأحكام المسؤولية العقدية (3. ).

ويثار تساؤل بشأن انتقال (شرط عدم المنافسة التجاريتة) إلى خلف طرفي

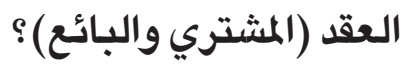

تفترض هذه الحالة أن يقوم التاجر المثتري للمتجر بإعادة بيع المتجر ذاته

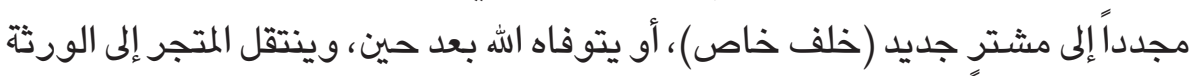

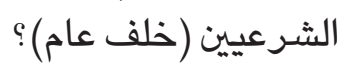

يبدو أن الرأي مستقر في هذه الحالة على انتقال أثثر الشرط إلى كل من يخلف(4) المشتري

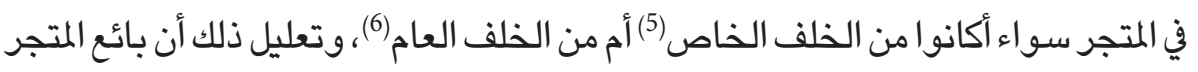

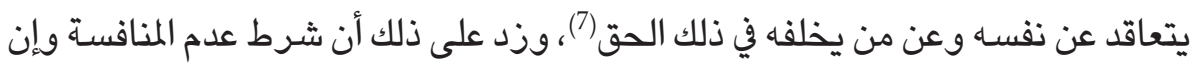

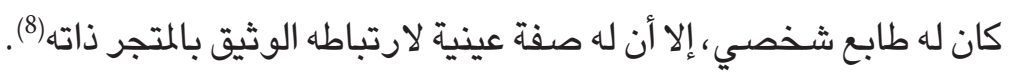

(1) د. مصطفى كمال طه، المرجع السابق، 673 . القاضي د. إلياس ناهيف، المرجع السابق، ص ص 122.

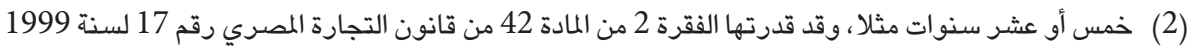
بعشر سنوات. (3) د. أحمد مفلح خوالدة، المرجع السابق، ص 150 ـ د. سوسن سعيد شندي، المرجع السابق، ص174.

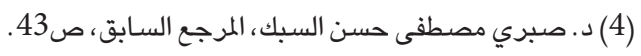

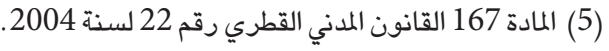
(6) المادة 165 القانون المدني القطري رقم 22 لسنة المادن 2004.

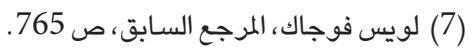

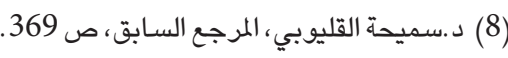


كما يُثار تسـاؤل حول مدى سريان (شرط عدم المنافسـة التجارية)، بحق أفراد أسرة

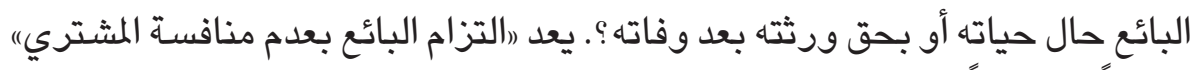

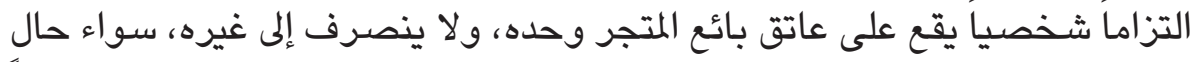

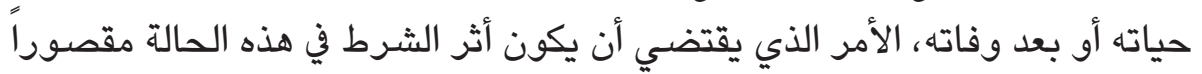

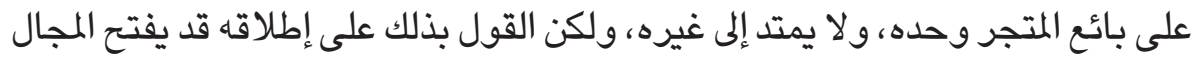

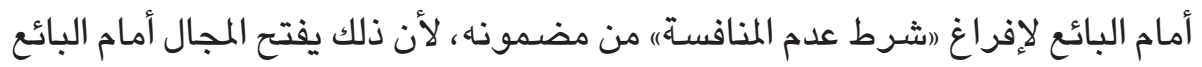

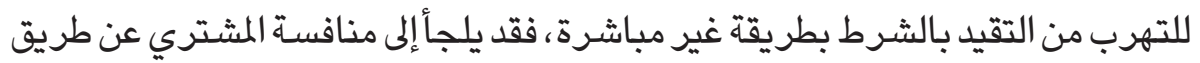

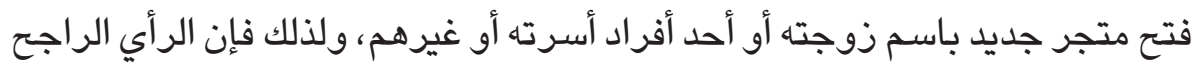

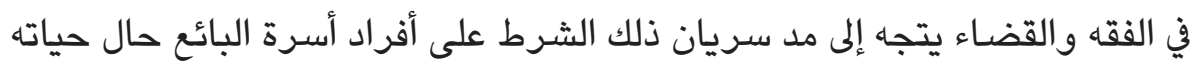

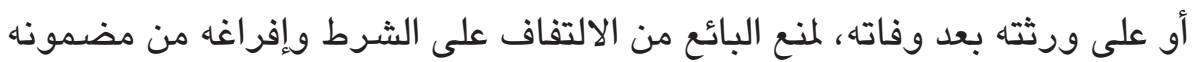

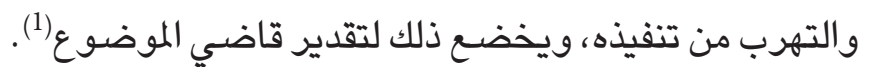

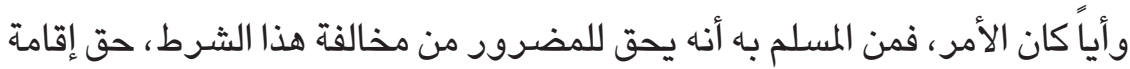

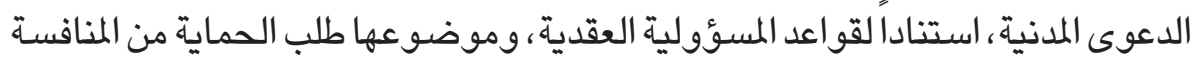

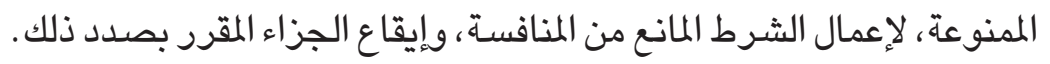

سادساً - عدم المنافسة التجارية بموجب شرط في عقد تأجيرالمتجر:

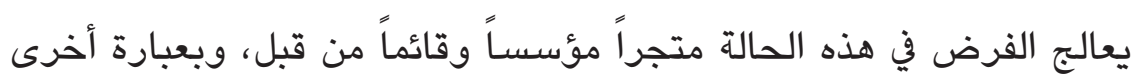

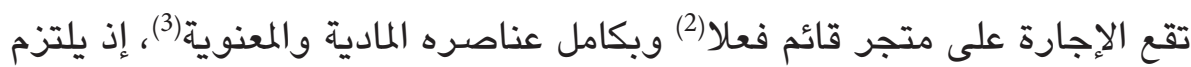

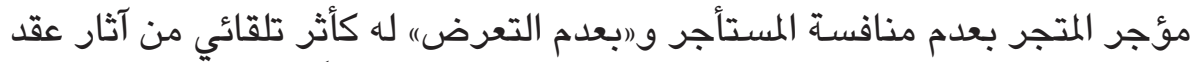

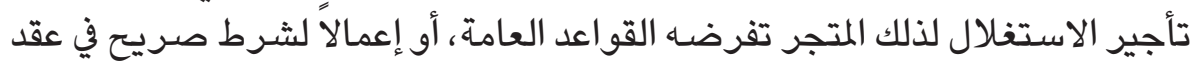

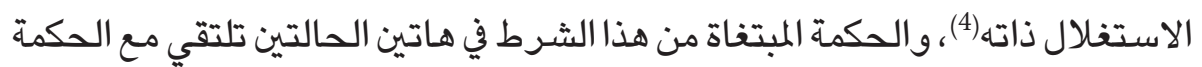

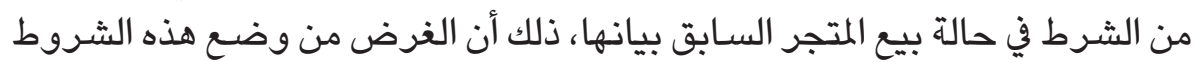

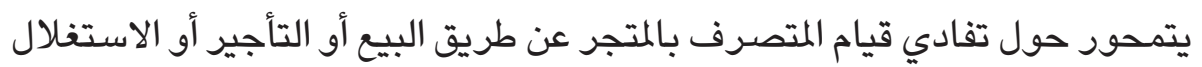

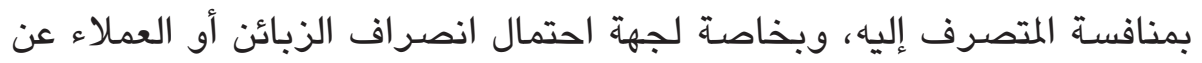

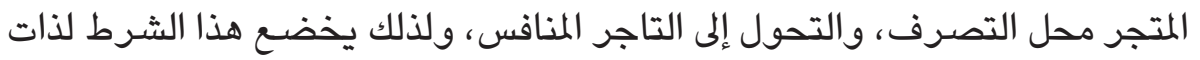

$$
\begin{aligned}
& \text { (1) د. صبري مصطفى حسن السبك، المرجع السابق، ص44. دـ سميحة القليوبي، المرجع السابق، ص } 370 .
\end{aligned}
$$

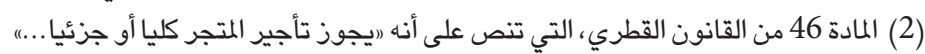

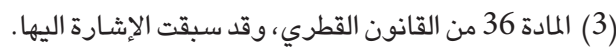

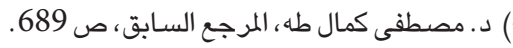


الأحكام التي تحكم شرط عدم المنافسة بموجب عقد بيع المتجر على النحو السـابق

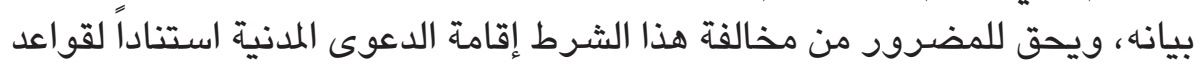

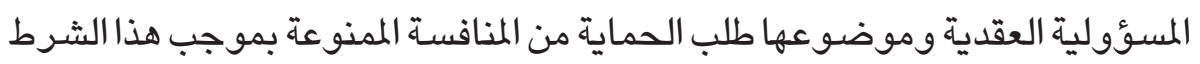
وإيقاع الجزاء المقرد بهذا الصدد.

\section{سابعاً - عدم المنافسة التجارية بموجب شرط في عقد العمل:}

يرتب قانون العمل القطري رقم 14 لسنة 2004 على العامل التزامات قانونية محددة، منها الالتزام بالمحافظة على أسرار صـاحب العمل وعدم إفشـائها، سواء خلال فترة العمل أو بعد ترك الخدمة(1)، وقد يرى صاحب العمل عدم كفاية ذلك الالتزام في

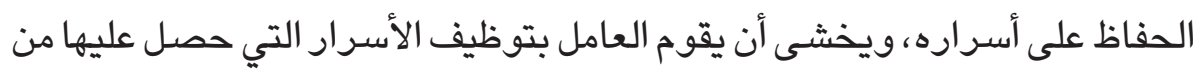

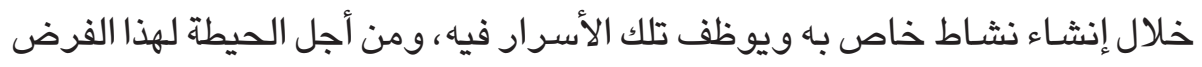

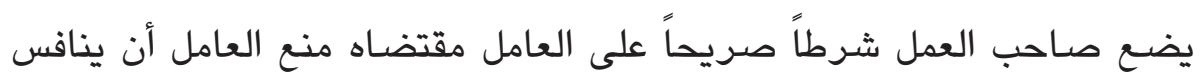
صاحب العمل أو يشترك في عمل ينافسه خلال سريان العقد وبعد انتهائه أيضـا. وقد أجاز قانون العمل القطري رقم 14 لسنة 2004 هذا الشرط في المادة 43 التي تنص على أنه (... و إذا كانت طبيعة العمل تسمح للعامل بمعرفة عملاء صـاحب العمل

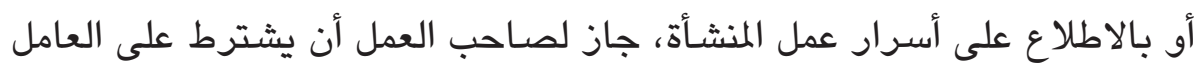

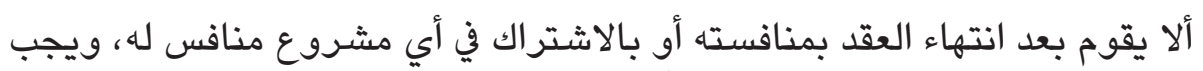

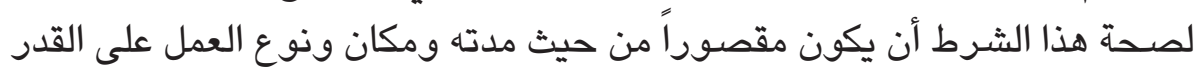

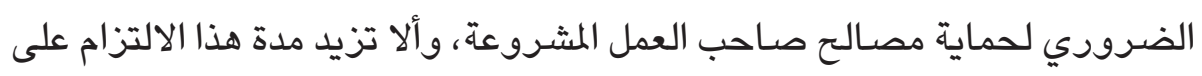
سنتين)، والغرض من هذا الشرط ليس حرمان العامل من حقه الطبيعي في حرية الطية

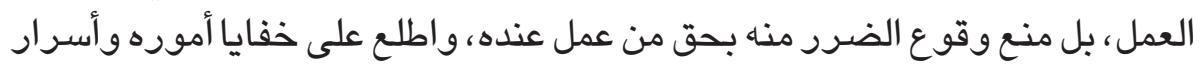

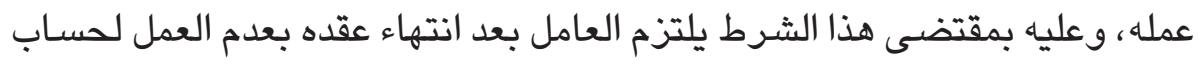

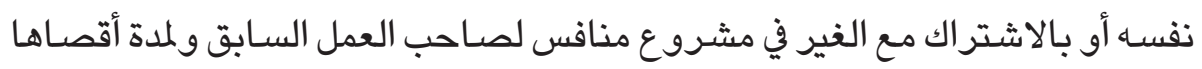

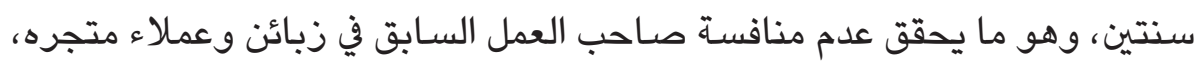
ويلزم لصحة هذا الشرط أن ينحصر المنع في ذات نوع النشاط التجاري أو المماثل

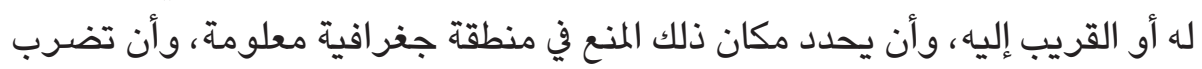

(1) المادة 42 / 8 من القانون المذكور التي تنص على أن يلتزم العامل ب (... عدم إفشاء أسرار العمل حتى بعد انتهاء العقد). 
له مدة زمنية معقولة، وهذا الشرط مبرر وشـائع ومسلم به قانونا وفقها وقضـاء(1)،

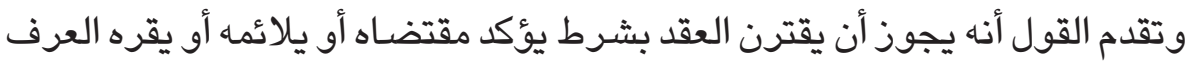

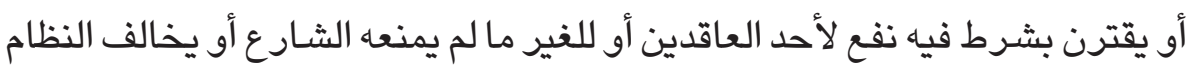

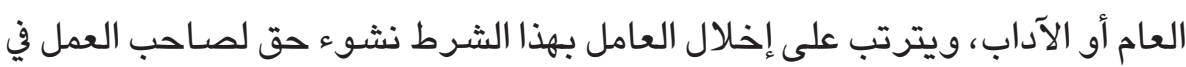

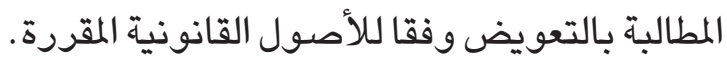

ومما سبق يتضح أن الحالات السابقة تشكل نماذج من صور المنافسة الممنوعة بموجب شرط عقدي ملزم، ومقرر لصالح أحد أطراف في مواجهة الطرف الآخر (2)،

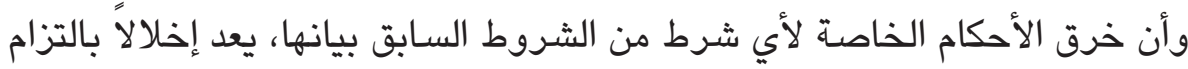

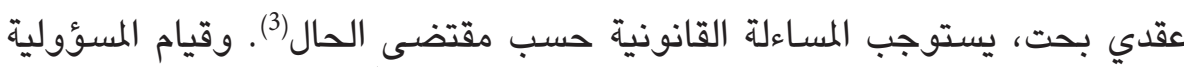
المدنية العقدية(4)، ووسيلة ذلك إقامة الدعوى المدنية، استناداً لقواعد المسؤولية العقدية،

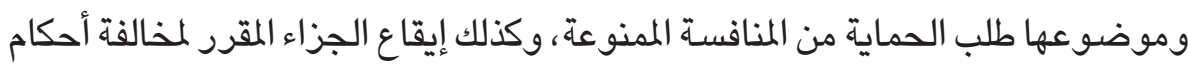
أي شرط من تلك الشروط، كالحكم بوقف المنافسة والتعويض إن كان له مقتضى (5).

\section{الفرع الثالث}

\section{مقارنة بين المنافسة غير المثروعة وبين المنافسة الممنوعة}

يوجد شبه محدود بين المنافسة غير المشروعة والمنافسة الممنوعة بشقيها (بنص القانون

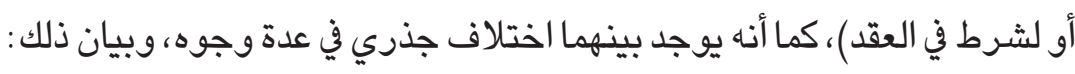
أولاً - أوجه الشبه بين المنافسة غير المشروعة وبين المنافسة الممنوعة: تلتقي المنافسـة غير المشروعة مع المنافسـة الممنوعة في المسائل الآتية :

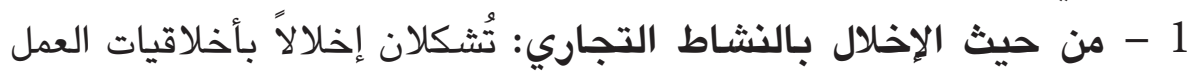

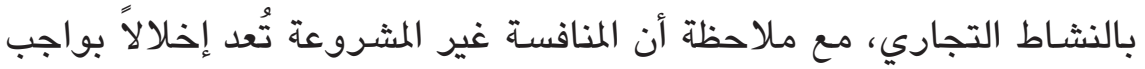

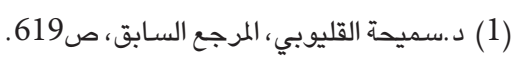

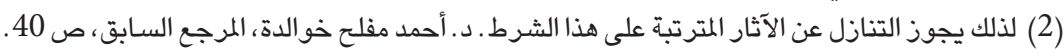

(3) Dr. Hussam El-Ehwany, Nader Mohamed Ibrahim, Introduction to Law, an Introductory

Study For Business Students, Part 1 (The Theory Of Law), Al Halabi Legal Publications, Beirut, 2004. p. 365.

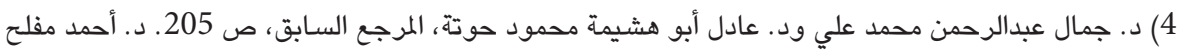

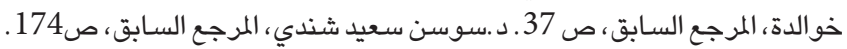

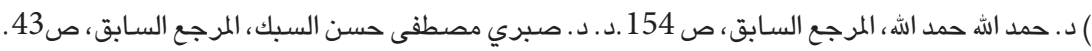


قانوني عام، بينما تُعد المنافسة الممنوعة إخلالا بنص قانوني خاص أو إخلالًا بالتزام عقدي.

2 - من حيث الهدف المبتفى: تُسهمان في تحقيق مصلحة مشروعة يحميها القانون،

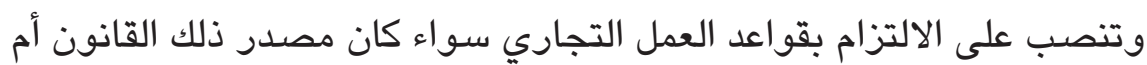

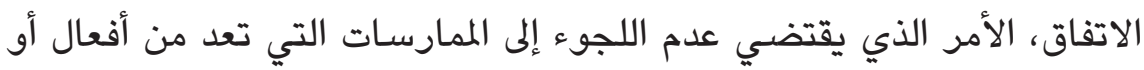

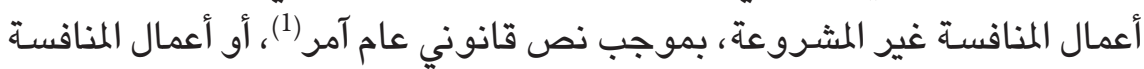

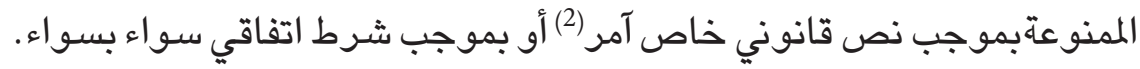

3 - من حيث الجزاء المقرر: يُرتبان المساءلة القانونية على كل من يقترف أياً منهما،

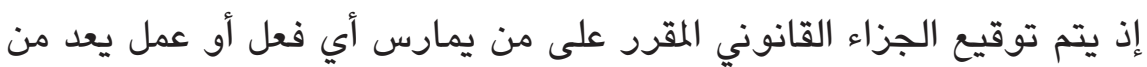

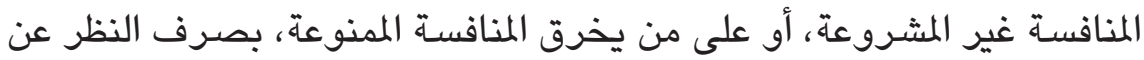

$$
\text { نوع هذا الجزاء ومداه(3). }
$$

4 - من حيث التقادم: يخضـع كل منهما للتقادم التجاري وفقا للأحكام القانونية

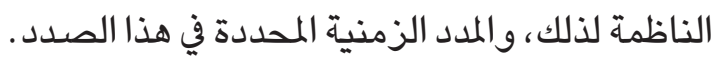

ثانياً - أوجه الاختلاف بين المنافسة غير المثروعة وبين المنافسة الممنوعة : تختلف المنافسة غير المشروعة عن المنافسة الممنوعة في المسـائل الآتية : 1 - من حيث طبيعة الفعل:تُعد أفعال أو أعمال المنافسة غير المشروعة غير مسموح

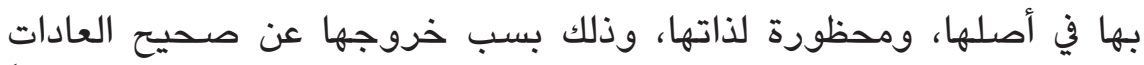

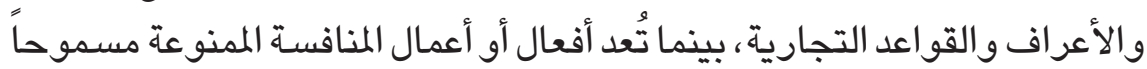

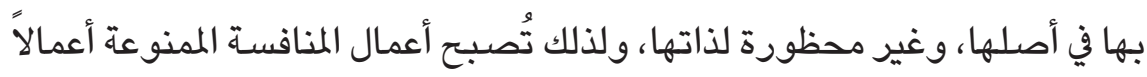

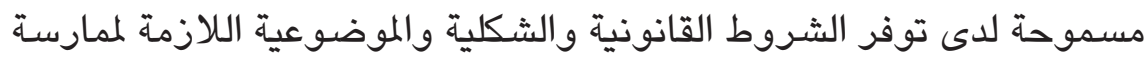

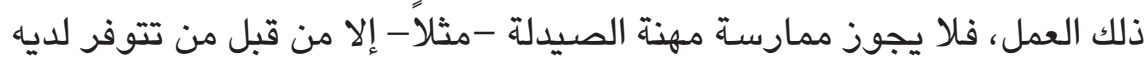

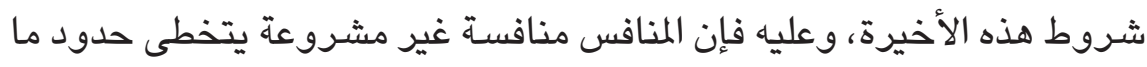
(1) المادة 199 من القانون المدني القطري رقم 22 لسنة 2004، والتي تنص على أن: ركل خطأ سبب ضرراً للغير يلزم من ارتكبه بالتعويض،. (2) المواد 68- 73 من قانون التجارة القطري رقم 27 لسنة 2006، وغيرها من المواد الناظمة للحقوق الفكرية، كما

سنرى لاحقا. (3) د. حمد الله حمد الل، المرجع السابق، ص 154. 
يعطيه القانون من حق ، أما المنافس منافسة ممنوعة، فإنه يختلق لنفسه حقاً ليس

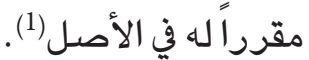

2 - من حيث مصدر الحظر يتمثل مصدر حظر أفعال أو أعمال المنافسـة غير المشروعة

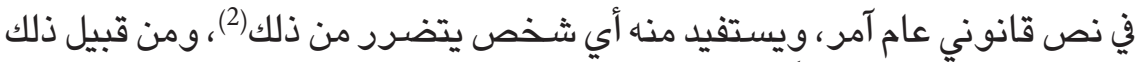

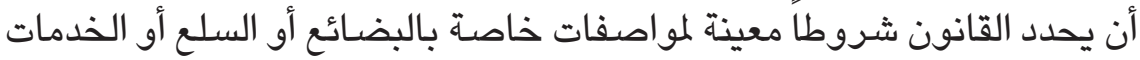

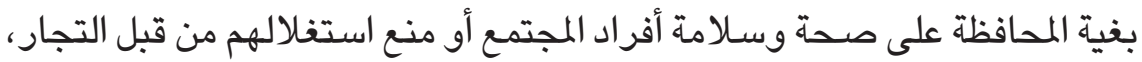

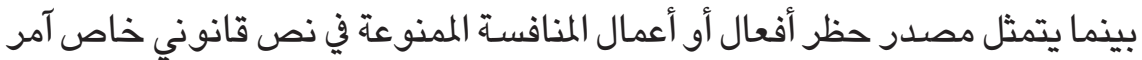

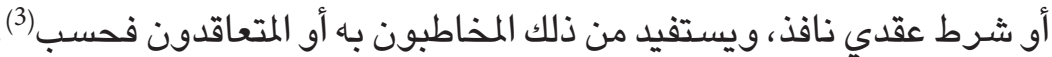
3 - من حيث نوع المصلحة: منع المنافسة غير المشروعة تهدف حماية مصلحة

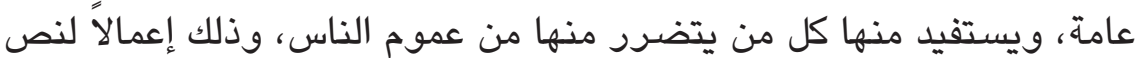

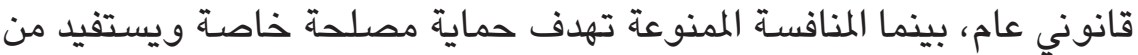

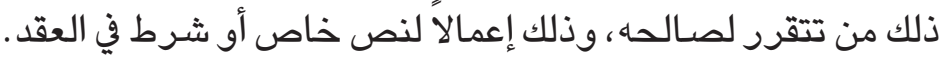
4 - من حيث نطاق الضرر: تتسع دائرة الأشخاص الذين يلحق بهم الضرر في

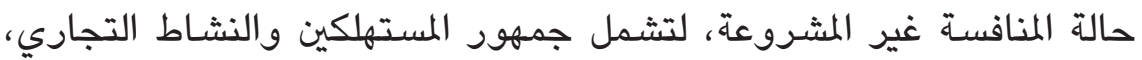

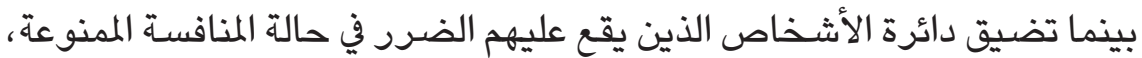

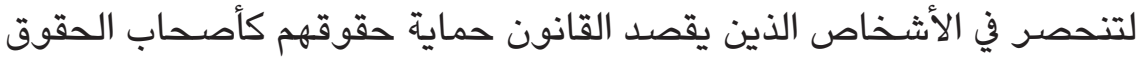

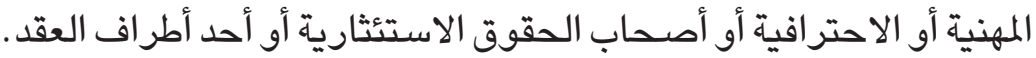
5 - من حيث نوع الدعوى: تتم حماية المضرور من المنافسة غير المشروعة عن

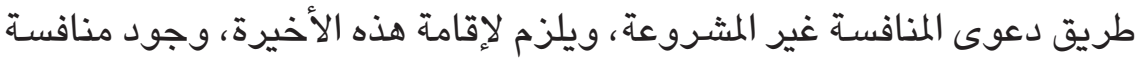

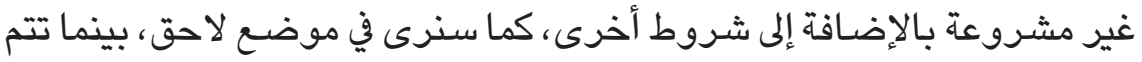

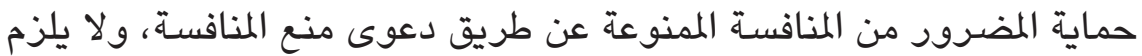

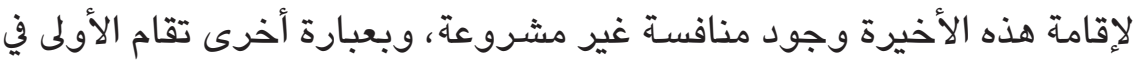

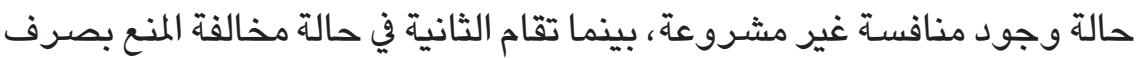

$$
\begin{aligned}
& \text { (1) د. لويس فوجال، المرجع السابق، ص726. } \\
& \text { (2) دون تقيد بصفة تاجر أو مستهلك أو غير ذلك. لك. لك. }
\end{aligned}
$$

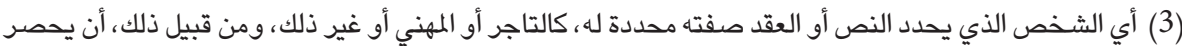

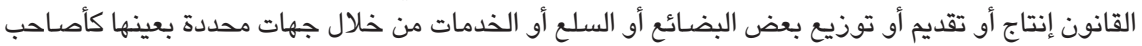

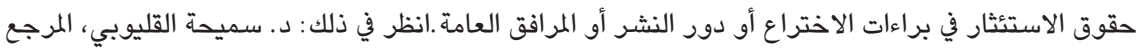

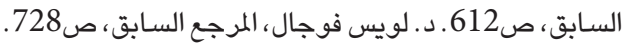


النظر عن وجود منافسـة مشـروعة أو غير مشـروعة(1).

6 - من حيث أساس الجزاء: يختلف الجزاء في المنافسة غير المشروعة عنه في

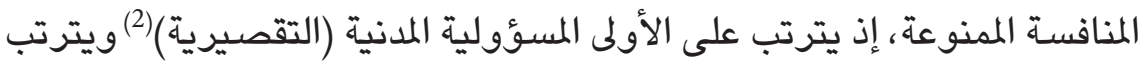

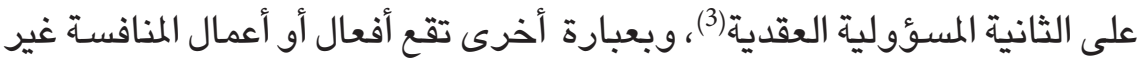

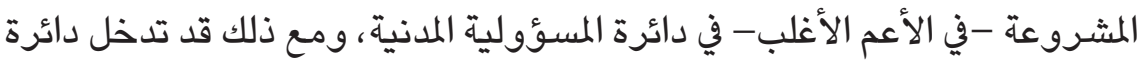

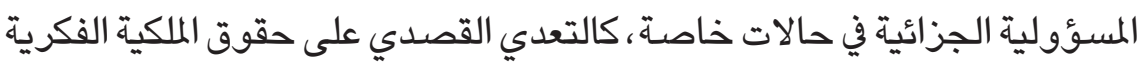

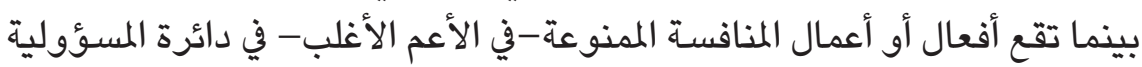
العقدية، ومع ذلك قد تدخل في دائرة المسؤولية الجزائية في حالات ارتكاب أفعال

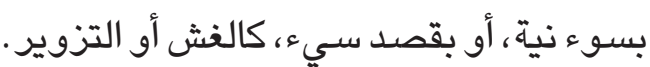
7 - من حيث نوع الجزاء: يتسـع نطاق الجزاء في حالة ممارسـات المنافسة غير المشروعة

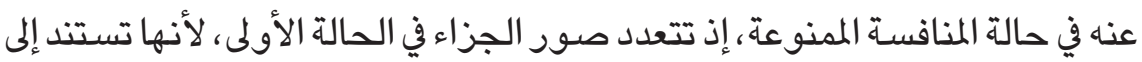

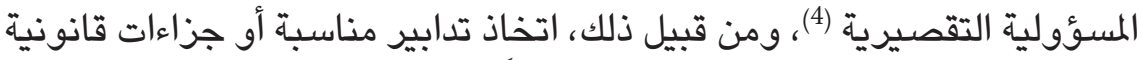

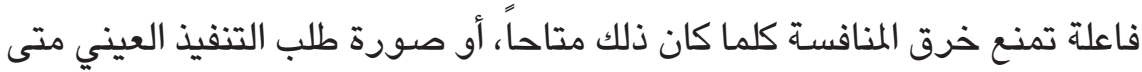

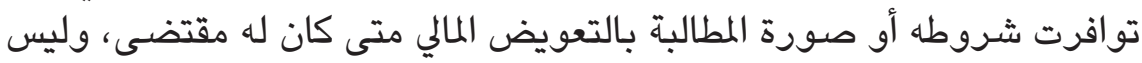

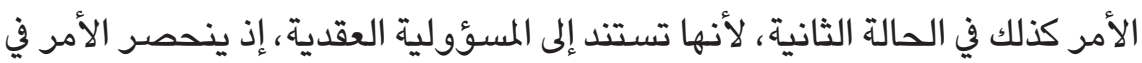

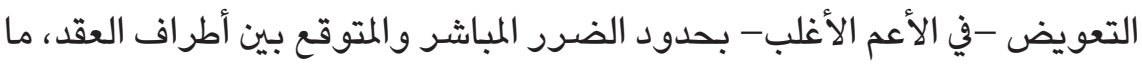

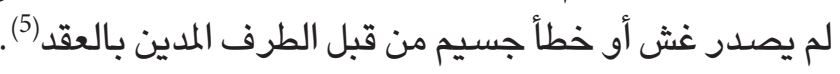

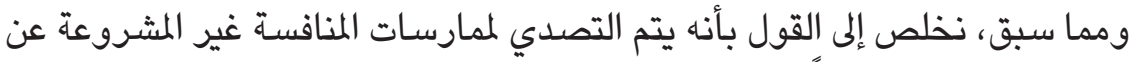

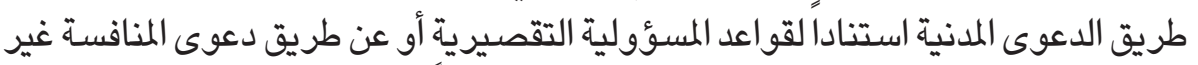

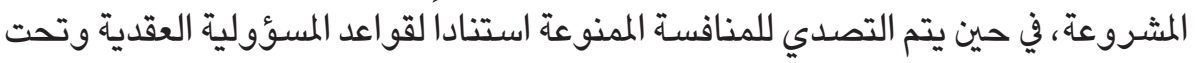

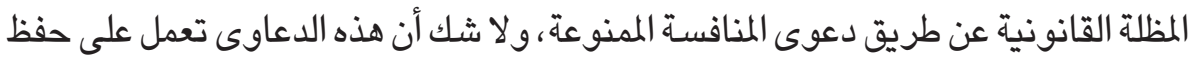

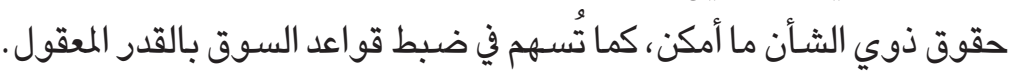

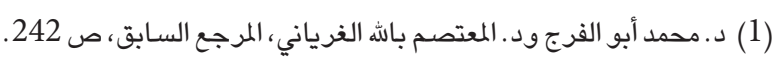

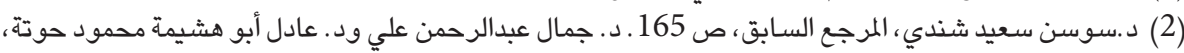

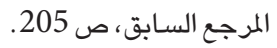
(3) وتوجد فروق بين المسؤوليتين لجهة الأهلية وعبء الإثبات والإعفاء ومدى التعويض والتقادم ـ د. أحمد مفلح

(4) Richard Stone, The Modern Law Of Contract, Seventh Edition, Routledge Cavendish, London and New York,2008.P.194.

$$
\text { (5 د. أحمد مفلح خوالدة، المرجع السابق، ص } 37 \text { ـ د.سوسن سعيد شندي، المرجع السابق، ص } 165 .
$$




\section{المبحث الثاني \\ صور المنافسة غير المشروعة}

نظم المشرع القطري صور المنافسـة غير المشروعة في المواد 68-73 من الفصل

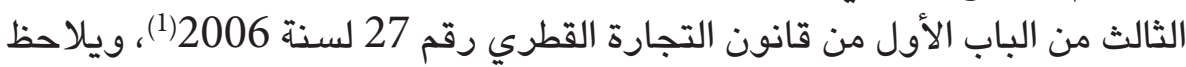

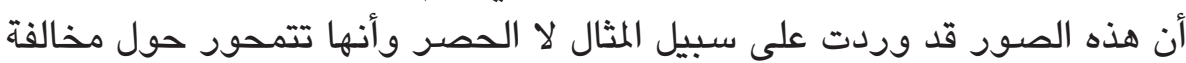

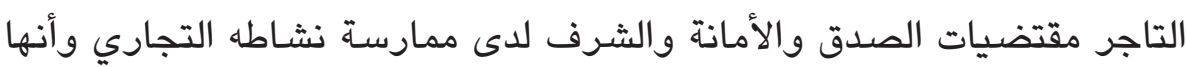

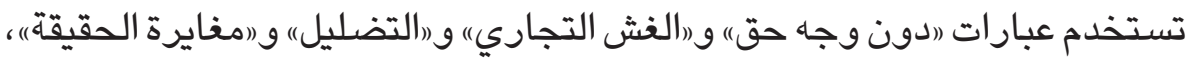

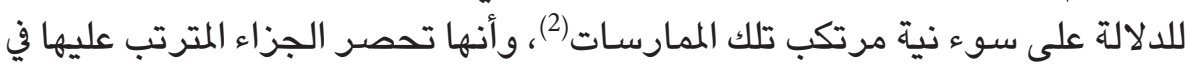

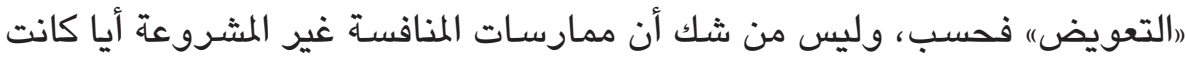

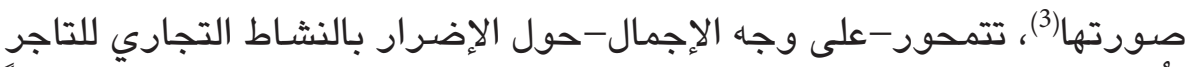

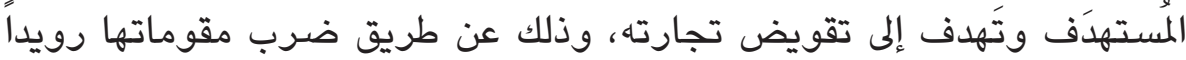

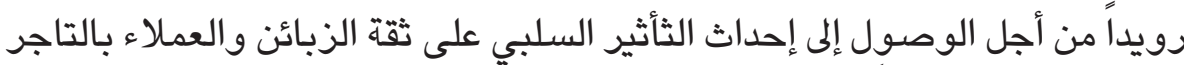

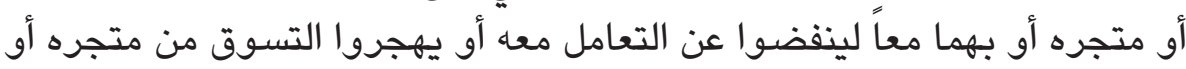

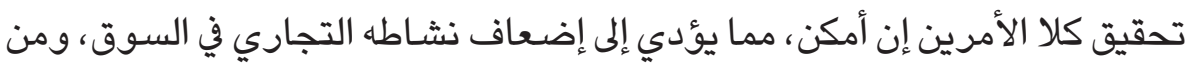

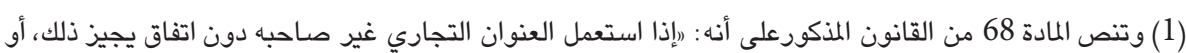

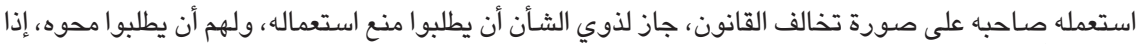

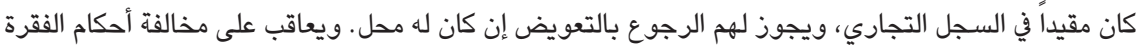

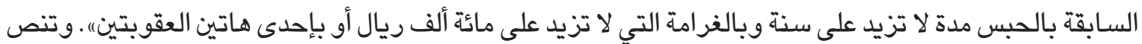

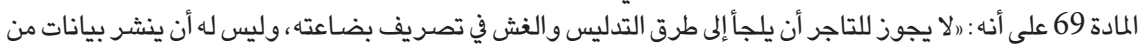

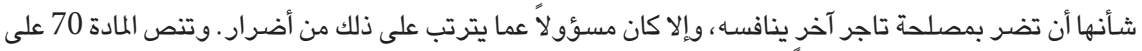

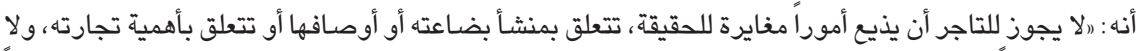

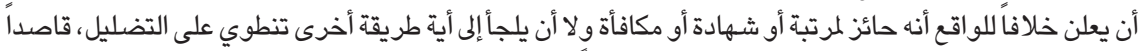

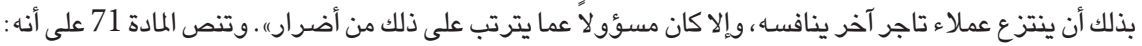

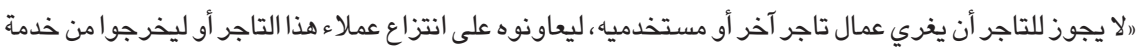

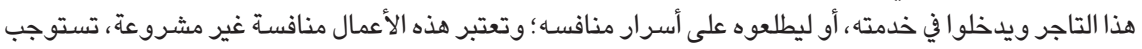

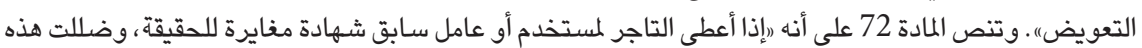

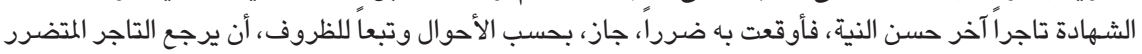

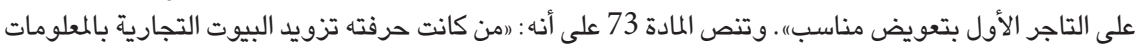

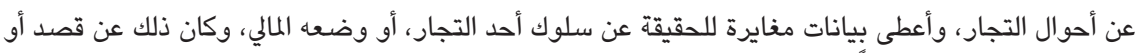

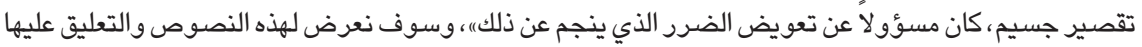
في ثنايا هذه الدراسة.

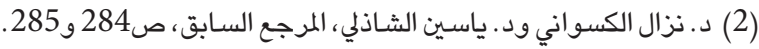

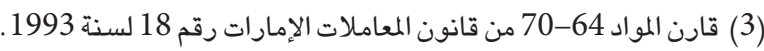


ثم اضطر اره إلى الخروج من تلك السوق تحت وطأة المنافسـة غير المشروعة (1). وتظهر صور المنافسـة غير المشروعة في الواقع العملي، عن طريق ممارسـات عديدة، وأسـاليب متنوعة ، ونماذ ج مختلفة ، وطرق شتحى قد تستعصي على الإحصـاء

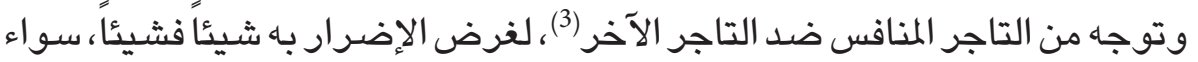
من خلال النيل من سمعته الشخصية أو من خلال التعدي على سمعةمتجره(4) أو الإثتتين معاً(5)، الأمر الذي يترتب عليه انكماش ثم اضمحلال ثم انفراط عُقدَّة الزبائن

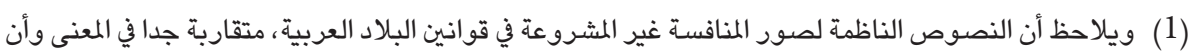

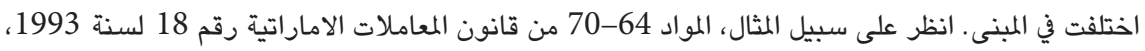

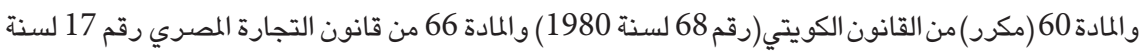

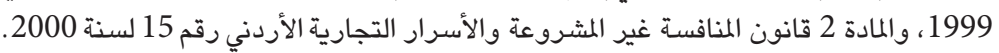

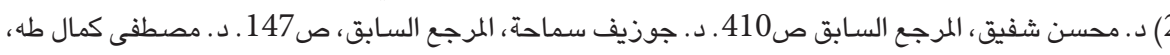

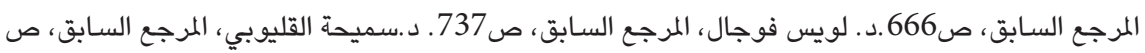

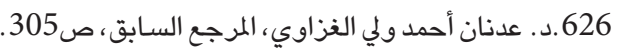

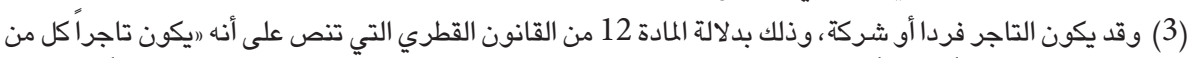

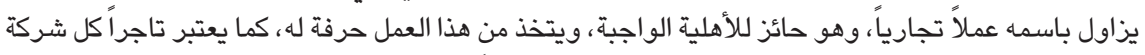

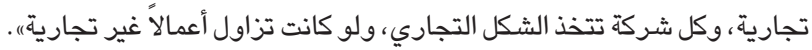

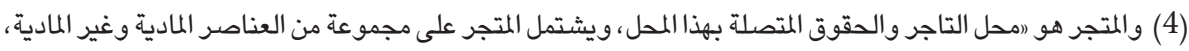

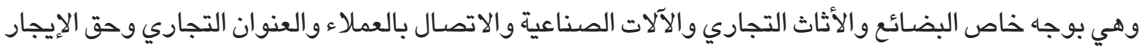

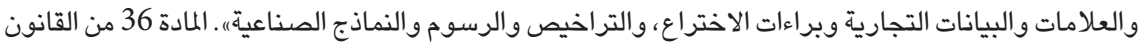

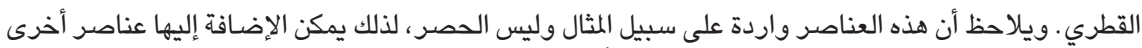

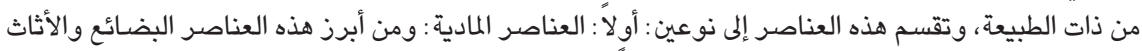

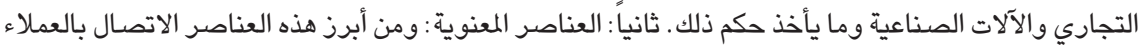

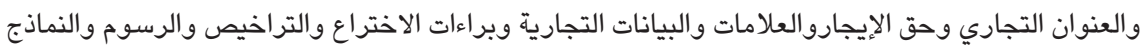

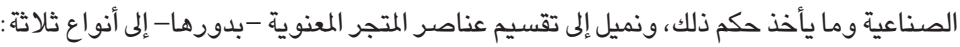

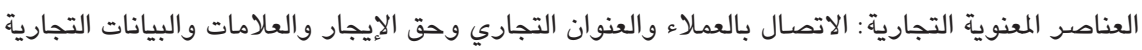
والتراخيص وما يأخذ حكم ذلك. العناصر المعنوية الصناعية : براءات الاختراع ولخداع والتراخيص والرسوم والنماذج الصناعية وما يأخذ حكم ذلك.

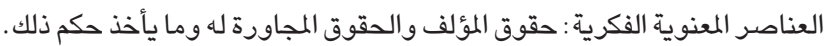

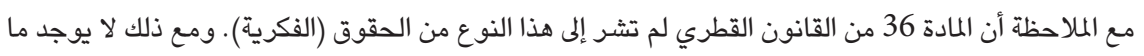

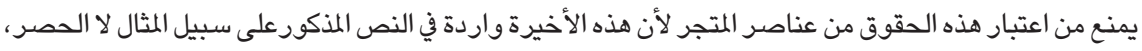

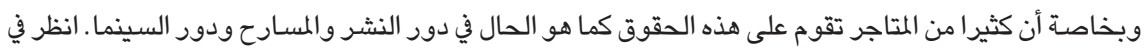

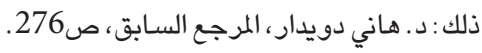
(5) إذ لكل منهما سمعة ذاتية، وتتمثل سمعة التاجر في الانطباع الحسن عن صفات الرعات هذا الشخص في عيون الغير(وينطبق

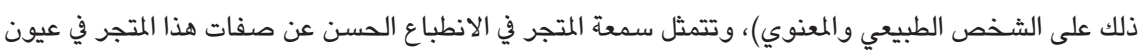

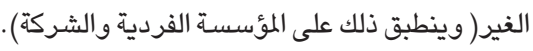


الجامعة لكافة مقومات المتجر ، كونهم روح المتجر، إذ يتلاشى هذا الأخير إن هَجره

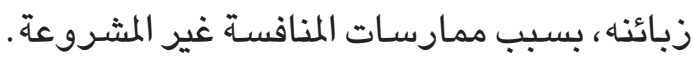
ونحاول في هذا المبحث الوقوف على صور المنافسـة غير المشروعة (1)، في المطالب

التـاليـة :

\section{المطلب الأول}

صور المنافسة غير المثروعة التي تتضمن اعتداء على سمعة التاحر تظهرالمنافسة غير المشروعة في هذه الحالة في صورة ممارسة أفعال أو أعمال توجه

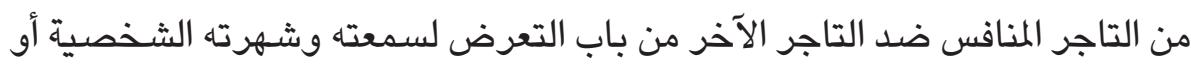

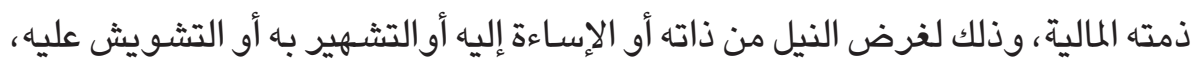

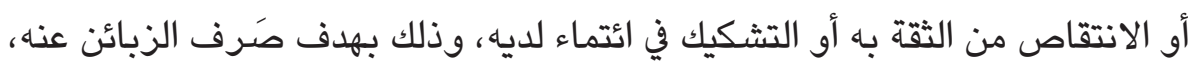
والتضييق عليه في تجارته لإخراجه من السوق التجاري، وبيان ذلك في الفروع الآتية:

\section{الفرع الأول}

\section{ممارسات المنافسة غير المثروعة}

التي تتضمن اعتداءً على شخص التاجر

تُوجه ممارسات المنافسة غير المشروعة في هذه الحالة في صورة أفعال أو أعمال من

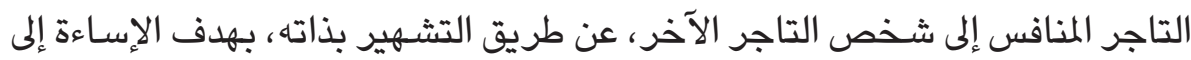

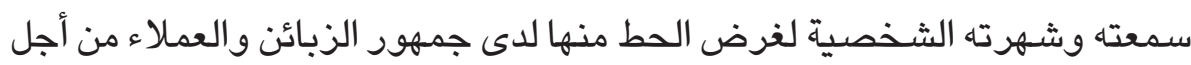

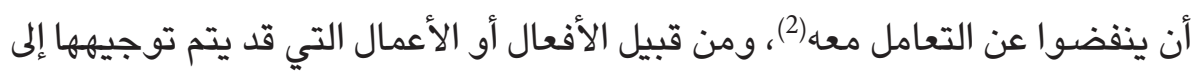

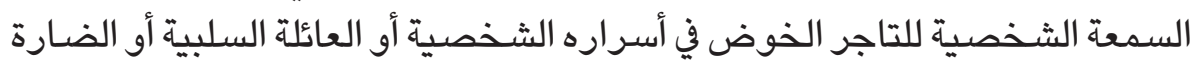

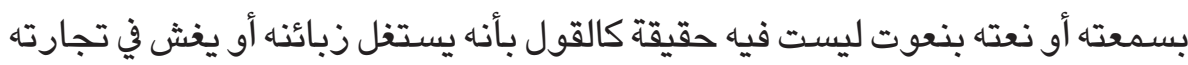

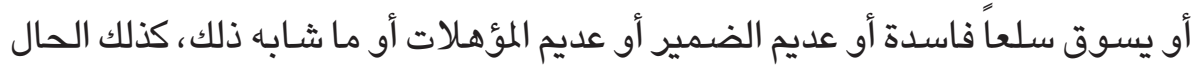

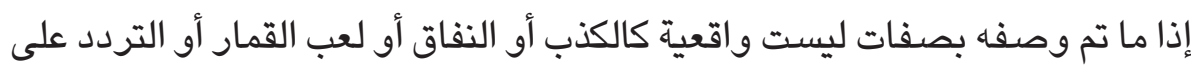
(1) د. محمد سـالم أبو الفرج ود. المعتصم باله الغرياني، المرجع السابق، ص247. د. نزال الكسواني ود. ياسين

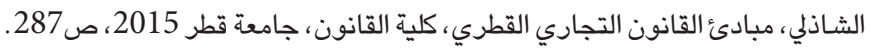

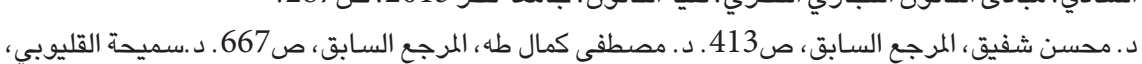

$$
\text { المرجع السابق، ص ص ص } 627 .
$$


الملاهي أو النوادي الليلية أو تناول الكحول أو تعاطي المخدرات وما شـابه ذلك، ويدخل

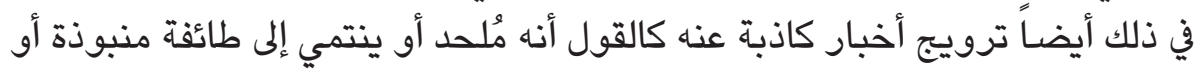

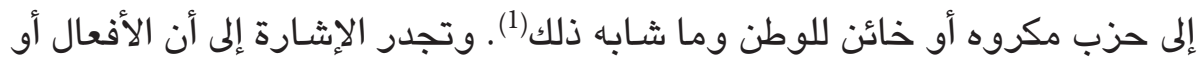

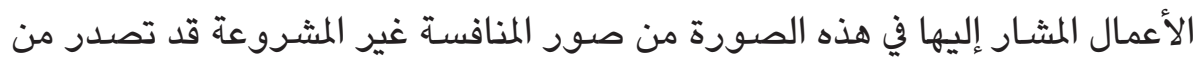

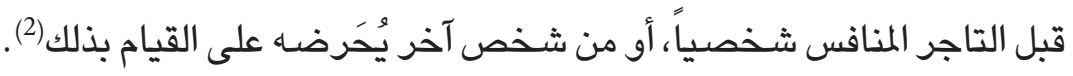

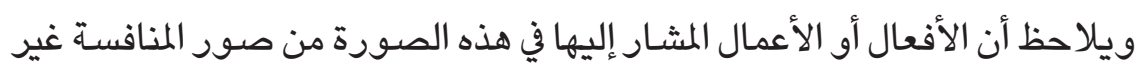

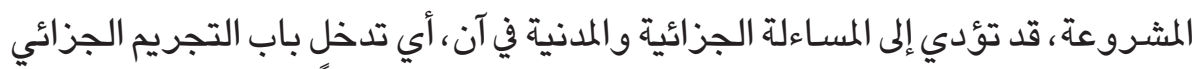

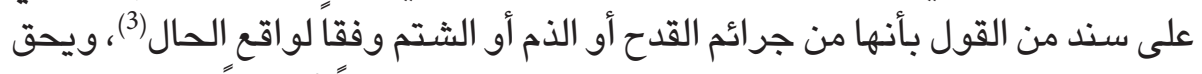

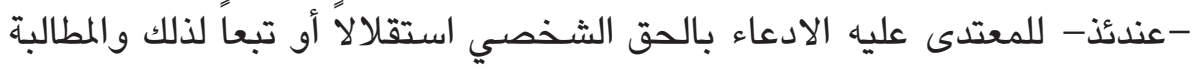

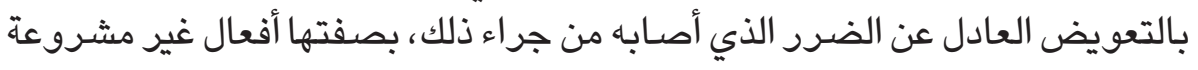

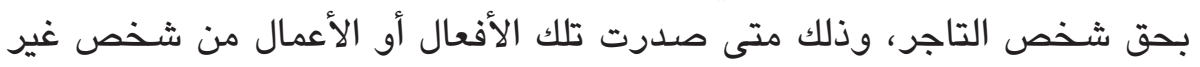

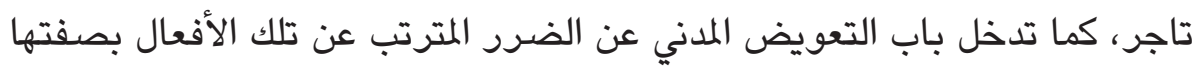

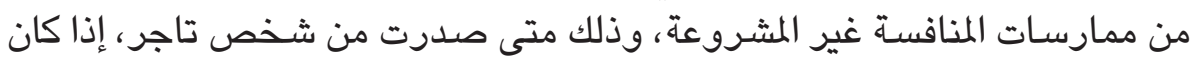

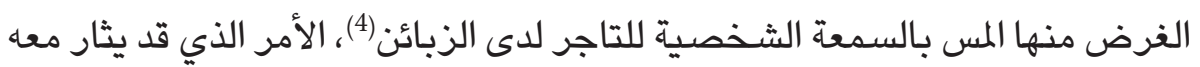

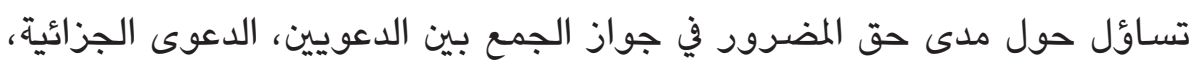

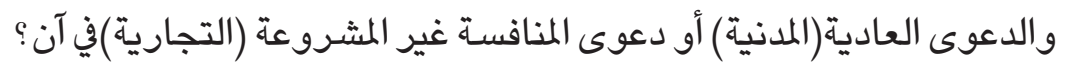

ونميل في هذا الصدد إلى القول إنه يحق للتاجر الذي توجه له أي من الأفعال أو

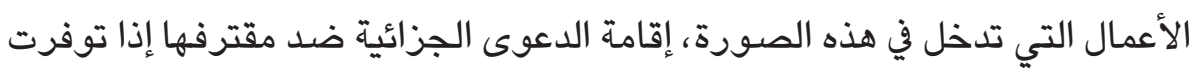

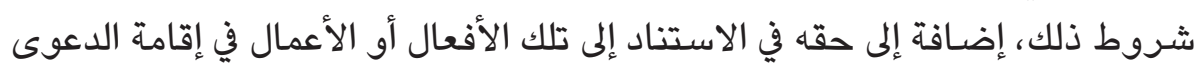

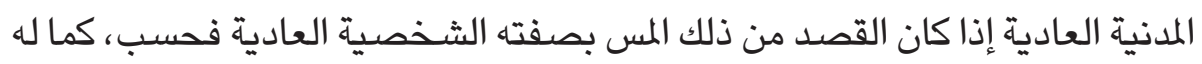

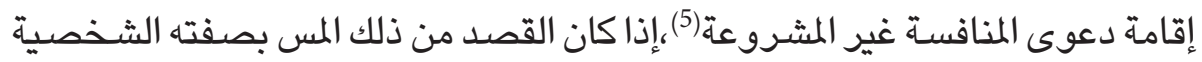

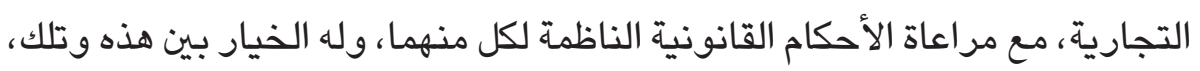

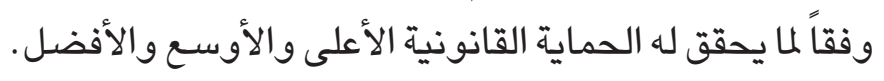
(1) د. عمر محمود حسن، المرجع السابق، ص 189 ـ د. صبري مصطفى حسن السبك، المرجع السابق، ص54. صـ ــ د.

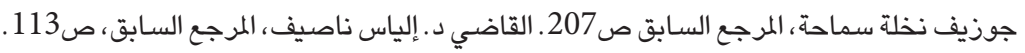

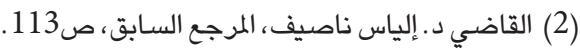

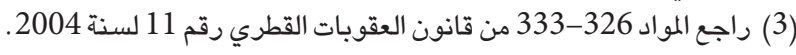

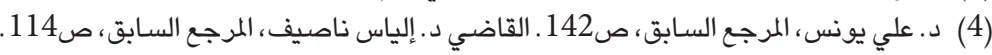

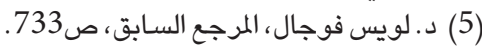




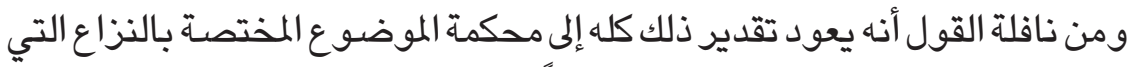
لها أن تقدر طبيعة تلك الأفعال أو الأعمال، وفقاً للظروف دئ التي تحدث فيها، والماللابسات

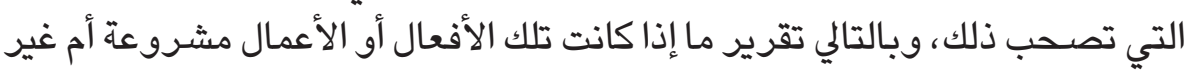

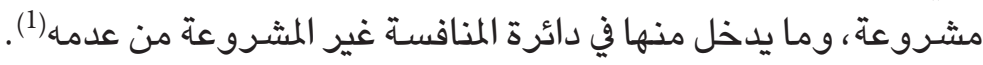
ويلاحظ أن القانون القطري يخلو من نص صريح يشير مباشرة إلى هذه الصورة من صور المنافسة المشروعة بعينها، ولعل السبب في ذلك يعود إلى الرغبة في ترك أمرها

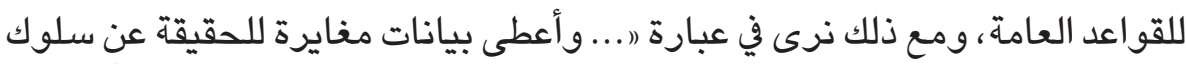

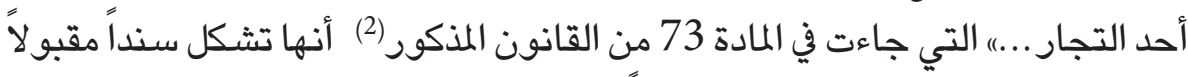

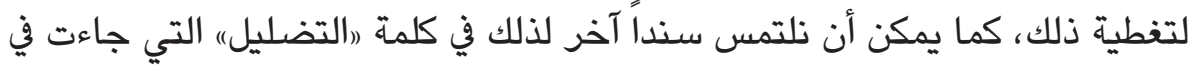

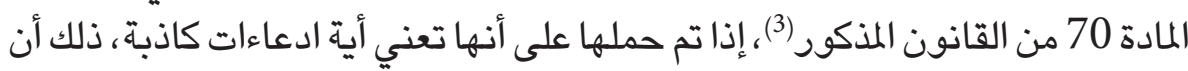

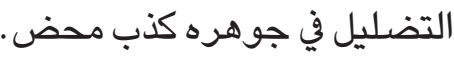

\section{الفرع الثاني}

\section{ممارسات المنافسة غير المثروعة}

\section{التي تتضمن اعتداءً على الذمة المالية للتاجر}

قد تتم ممارسـات المنافسـة غير المشروعة في هذه الحالة، في صسورة أفعال أو أعمال

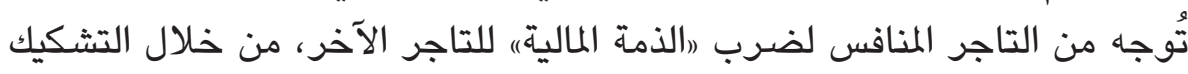

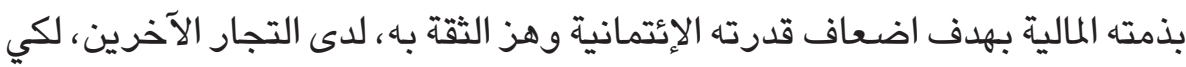

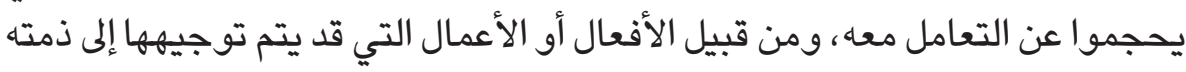

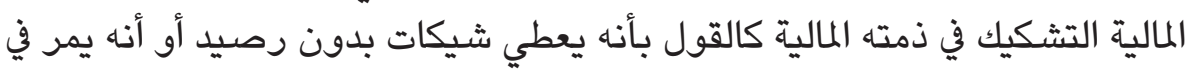

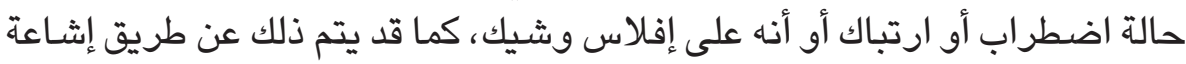

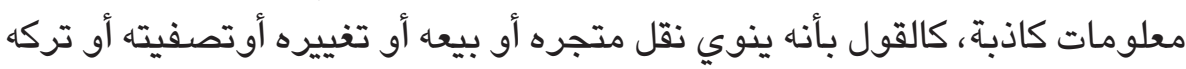

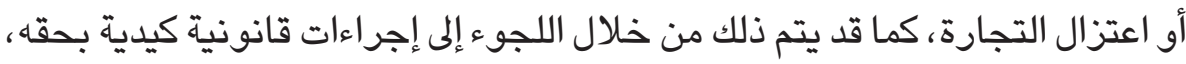

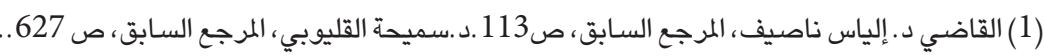

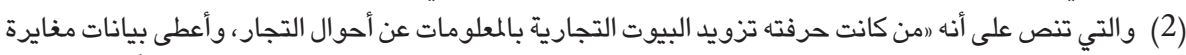

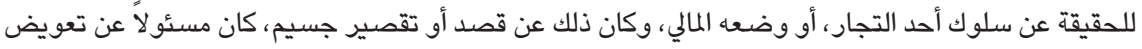

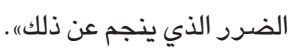

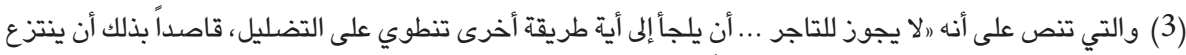

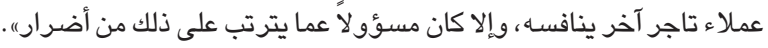


كالحجز عليه بلا مقتضى أو إقامة دعاوى عليه بلا مسوغ، أو نشر أخبار عن دعاوى

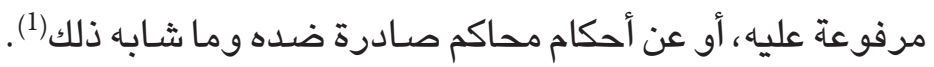
ويلاحظ أن الأفعال أو الأعمال المذكورة قد تصدر من التاجر المنافس وقد تصدر

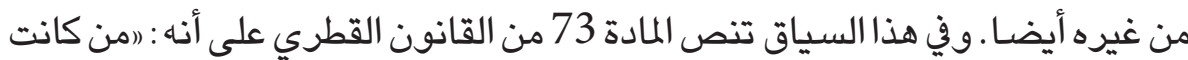

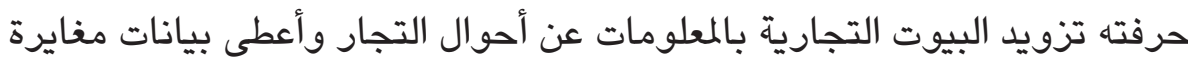

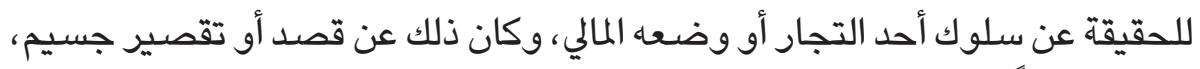
كان مسؤولاً عن تعويض الضرى الذي ينجم عن ذلكها.

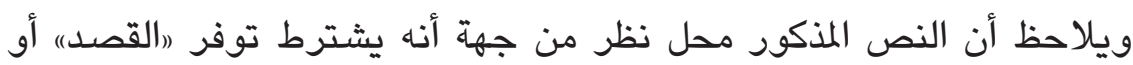
"التقصير الجسيم) لدى من يقدم على ارتكاب أي فعل من الأفعال التي أشـار إليها

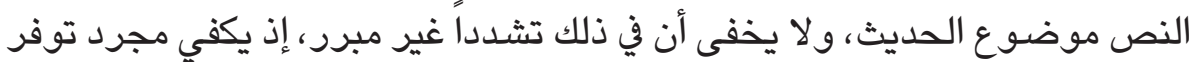

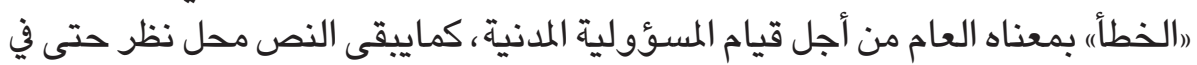

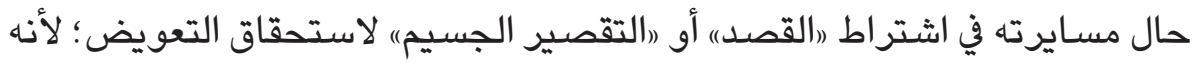

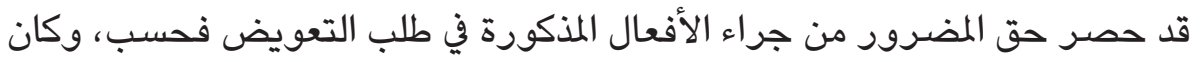

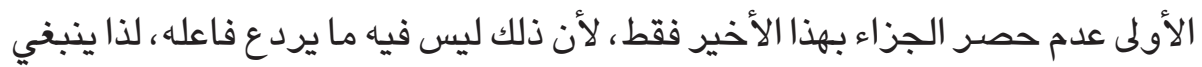

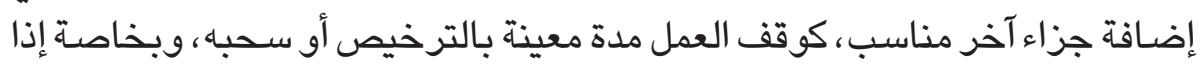

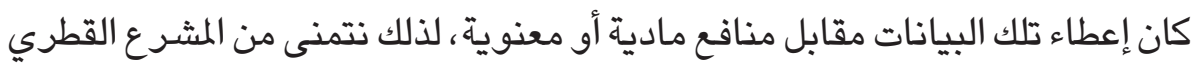
إعادة النظر في هذا النص بصورة تأخذ في الاعتبار ما ذُكر ماته

\section{المطلب الثاني}

\section{صور المنافسة غير المثسروعة}

\section{التي تتضمن اعتداءً على العمل في متجر التاجر}

تظهر المنافسة غير المشروعة في هذه الحالة في صورة ممارسة أفعال أو أعمال

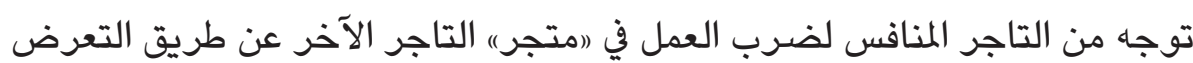

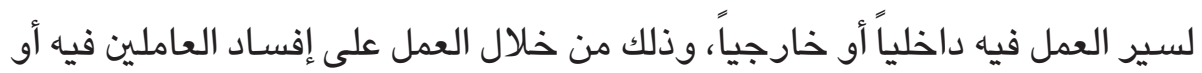
من خلال إضعاف قدرته على المنافستة، وبيان ذلك في الفروع الآتية :

\footnotetext{
(1) د. محسن شفيق، المرجع السابق، ص414. د.سميحة القليوبي، المرجع السابق، ص 628 ـ د. جوزيف نخلة

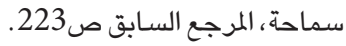




\section{الفرع الأول}

\section{ممارسات المنافسة غير المثروعة}

\section{التي تتضمن اعتداء على العمل الداخلي للمتجر}

قد توجه ممارسـات المنافسـة غير المشروعة في صورة أفعال أو أعمال إلى العمل

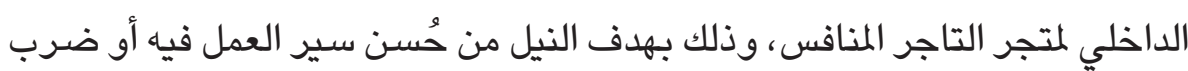

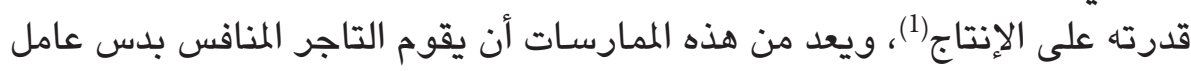

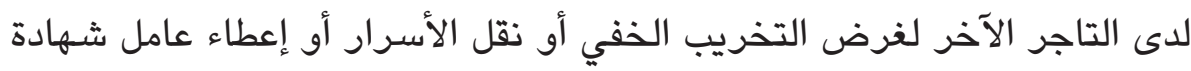

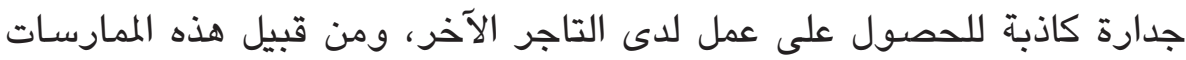

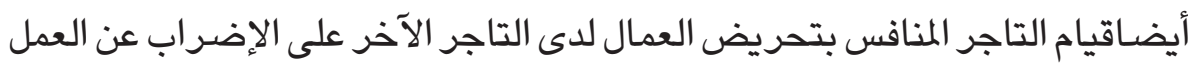

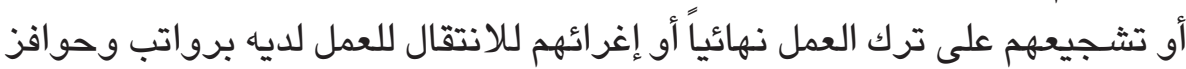

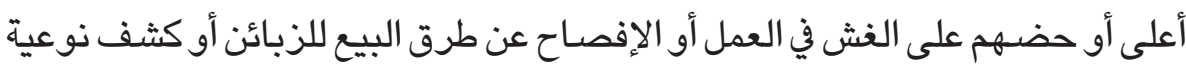

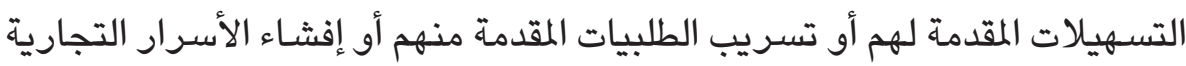

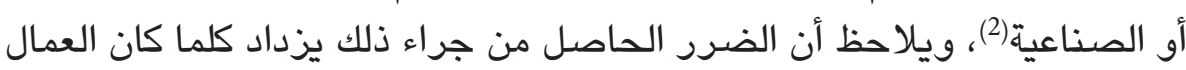

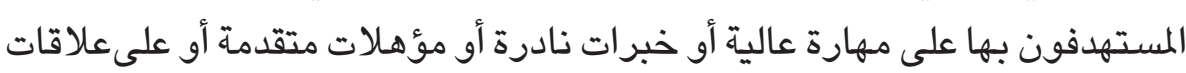
مباشرة بزبائن المتجر المنافس(3).

ويحارب القانون القطري هذه الممارسات بوضسوح، إذ نص في المادة 71 منه على أنه :

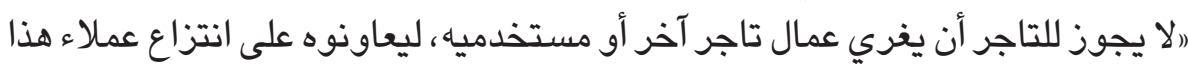

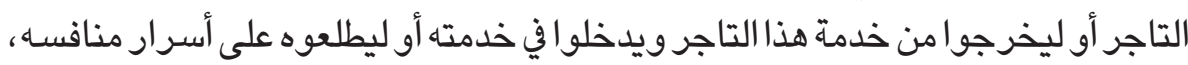

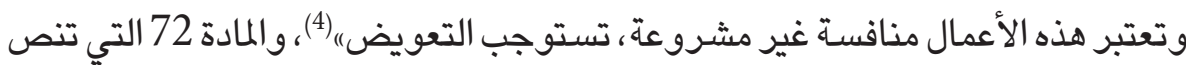

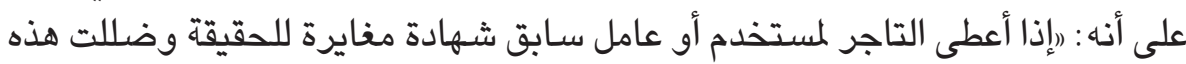

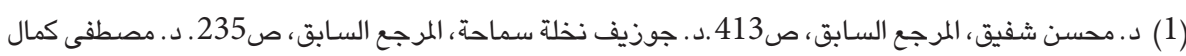

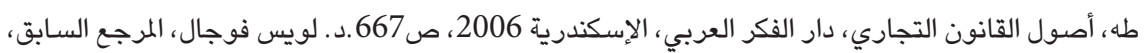

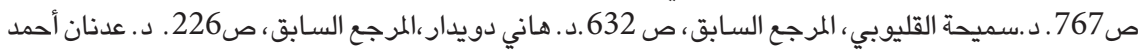

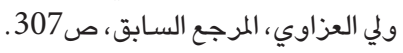

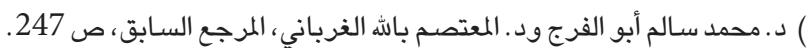

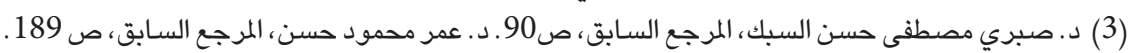

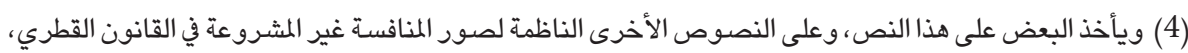

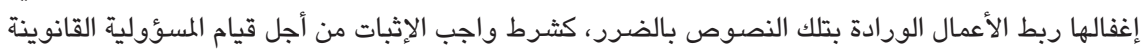

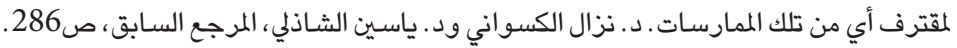


الشـهادة تاجراً آخر حسن النية فأوقعت به ضرراً، جاز بحسب الأحوال وتبعاً للظروف أن

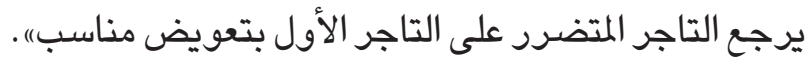

ويلاحظ أن القانون القطري قد قيد الحالة الأخيرة، حتى تدخل دائرة المنافسة غير المشروعة بقيود ثلاثة هي: الأول : أن تكون بيانات الشهادة المعطاة للعامل مغايرة للحقيقة (كاذبة). والثاني : أن يكون التاجر الآخر حسن النية. والثالث : أن يلحق التاجر الآخر من جراء ذلك ضرراً. ويقتضي أن تتوفر هذه الشروط مجتمعة لكي يعد هذا الفعل من أفعال المنافسة غير إندا

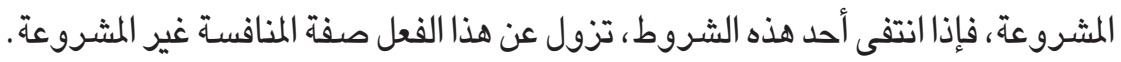

$$
\text { الفرع الثاني }
$$

\section{ممارسات المنافسة غير المثروعة}

\section{التي تتضمن اعتداءً على العمل الخارجي للمتجر}

قد تظهر ممارسات المنافسة غير المشروعة في صورة أفعال أو أعمال توجه من

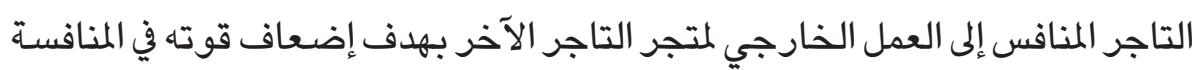

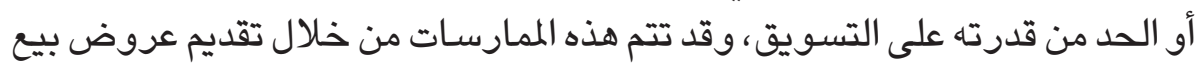

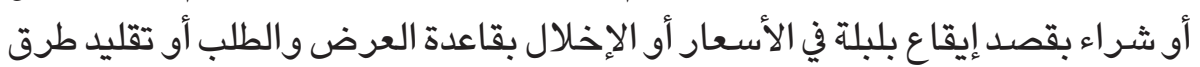

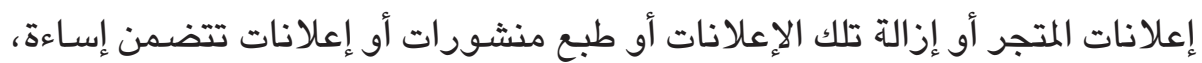

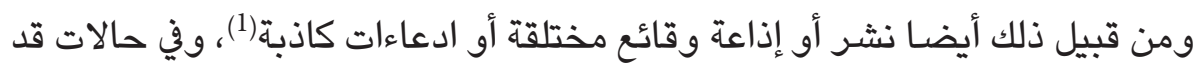

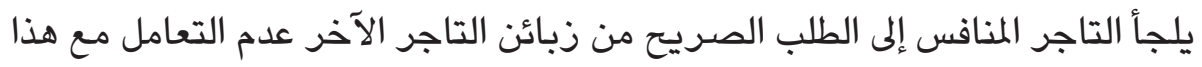

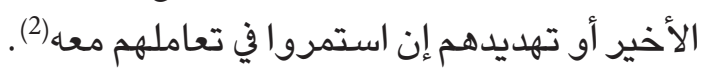

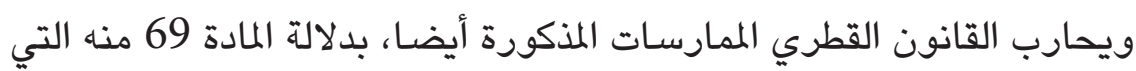

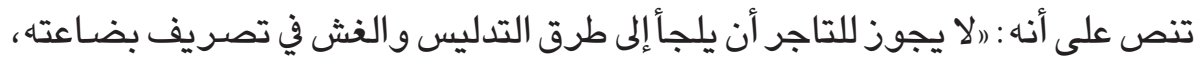

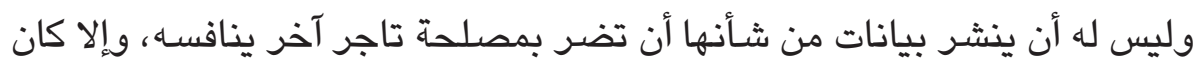

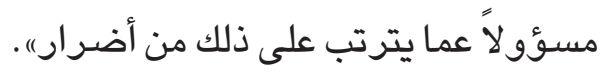

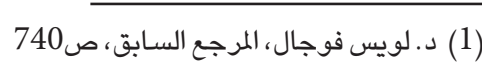

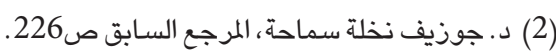


ويلاحظ على النص المذكور، أنه قد حصر مسؤولية مرتكب الأفعال المذكورة في

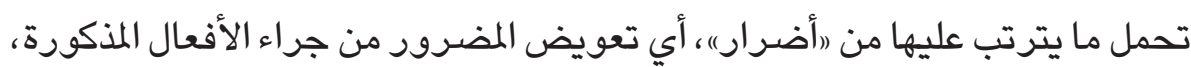

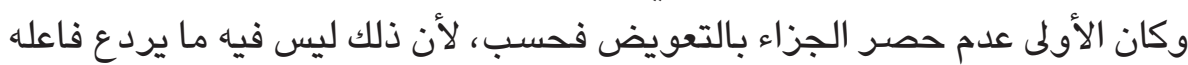

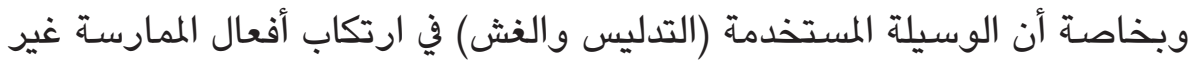

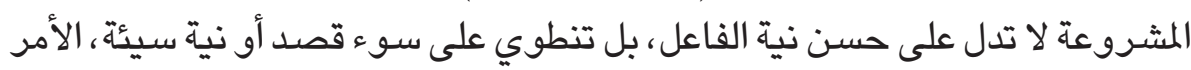
الذي يقتضي فرض عقوبة أخرى بجانب التعويض، كفرض عقوبة جزائية (تبعية) كالغرامة أيضـا أو أي عقوبة أخرى مناسبة.

\section{المطلب الثالث}

\section{صور المنافسة غير المثروعة}

\section{التي تتضمن اعتداءً على عناصر متجر التاجر}

يُعرف القانون القطري المتجر بأنه : امحل التاجر والحقوق المتصلة بهذا المحل،

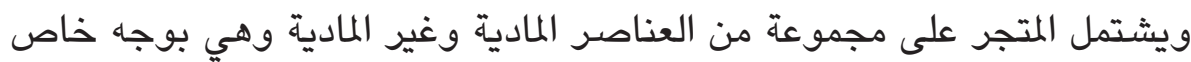

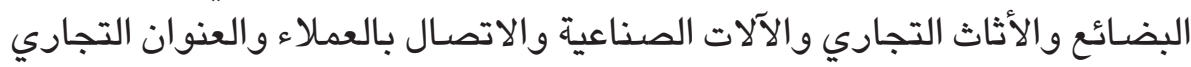

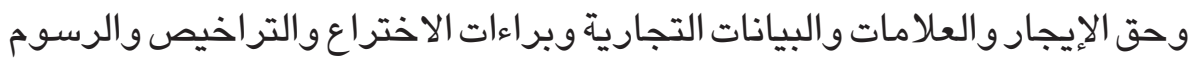

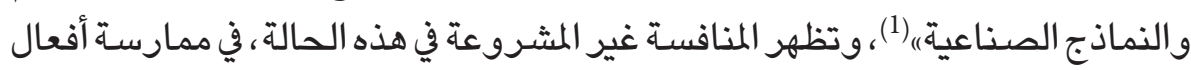

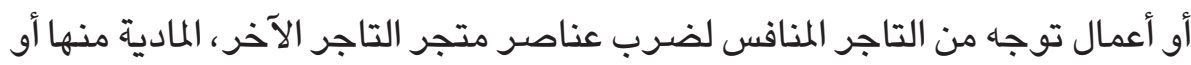

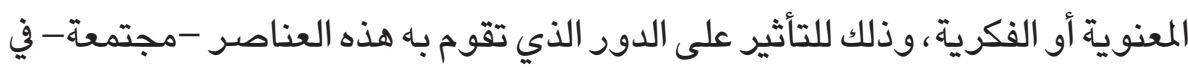

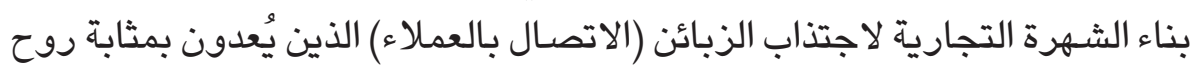

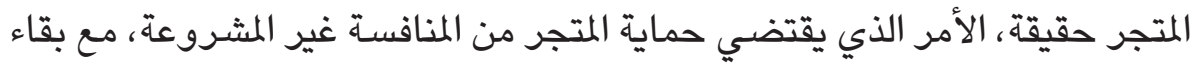

(1) المادة 36 من القانون المذكور، ويلاحظ أن العناصر التي يتضمنها نص المادة المذكور واردة على سبيل المثال

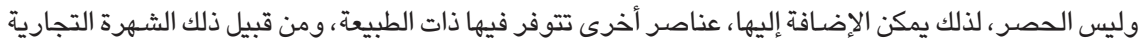

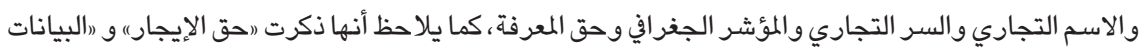

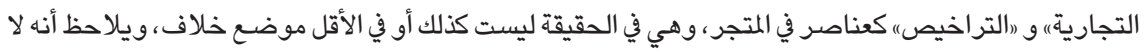

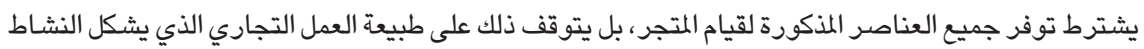

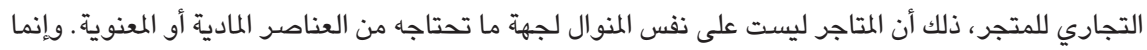

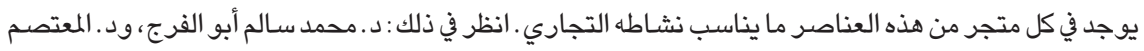

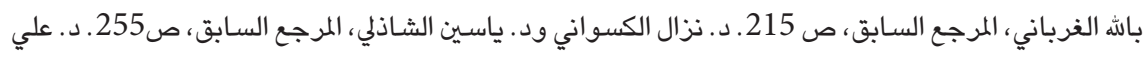

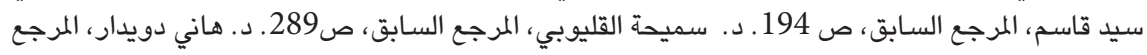

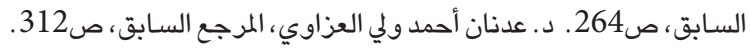


كل عنصر من عناصره متمتعاً بالحماية القانونية الخاصـة به وفقاً لطبيعته الذاتية المستقلة(1)، ونُبين ذلك في الفروع من الآتية :

\section{الفرع الأول}

\section{ممارسات المنافسة غير المثروعة}

\section{التي تتضمن اعتداءً على العناصر المادية للمتجر}

تشمل العناصر المادية للمتجر "البضائع) و"الأثاث التجاري" و"الآلات

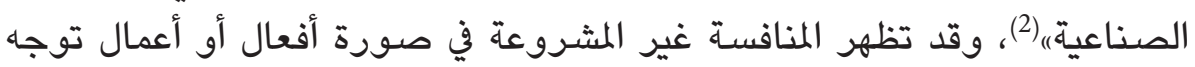

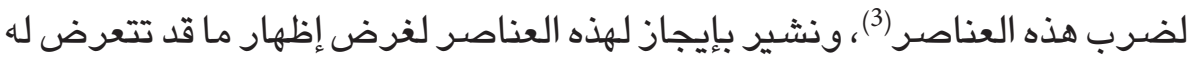

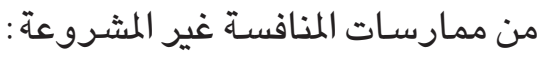

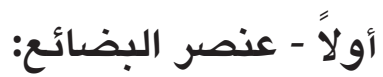

يقصد بعنصر (البضائع) المنتجات أو السلع أو ما يأخذ حكمها من المنقولات المادية

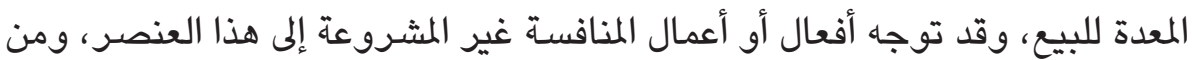

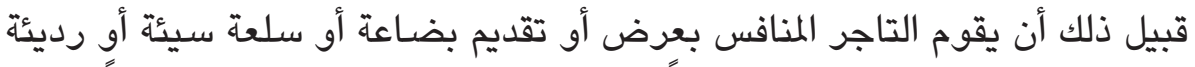

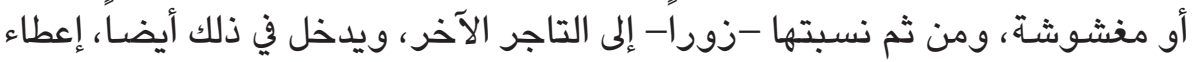

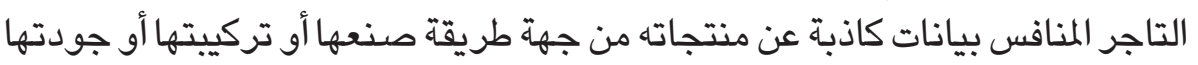

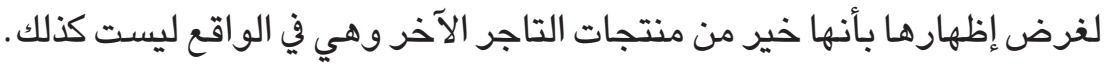
ثانياً - عنصر الأثاث التجاري (المهمات): يقصد بعنصر الأثاث التجاري الأشياء أو الأدوات أو الأغراض أو الديكورات

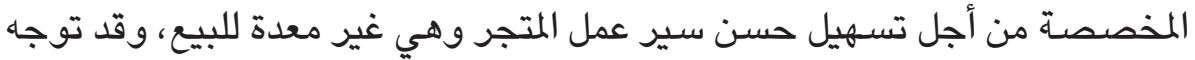

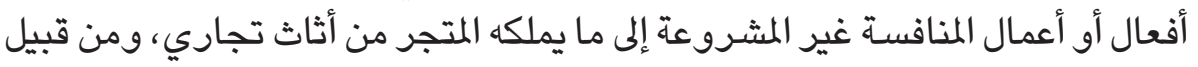

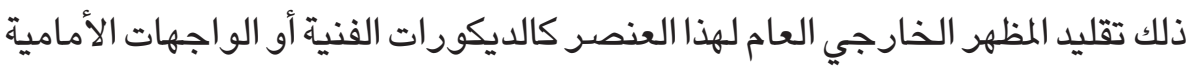

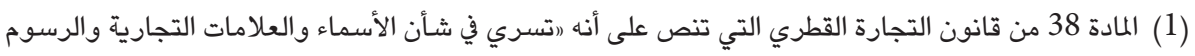

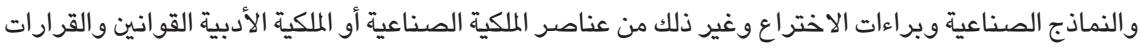
الخاصسة بذلك). (2) المادة 36 من قانون القطري. ـ د. محمد سالم أبو الفرج، ود ـ المعتصم باله الغرباني، المرجع السابق، ص 227 ــ د.

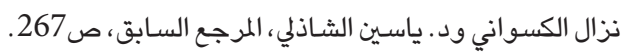

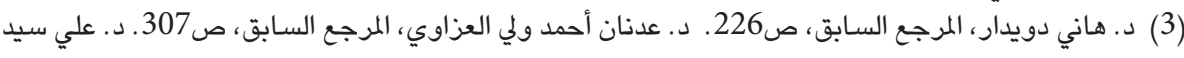

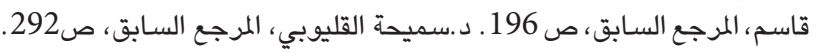




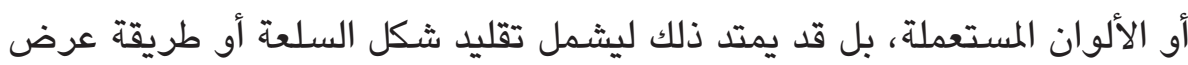

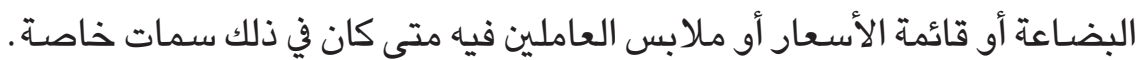
ثالثاً - عنصر الآلات الصناعية:

يقصد بعنصر الآلات الصناعية المعدات التي يستخدمها المصنع لتصنيع المنتجات

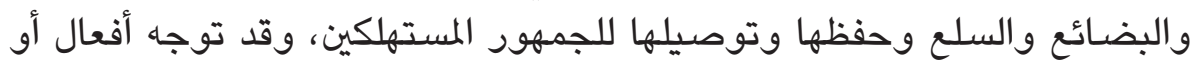

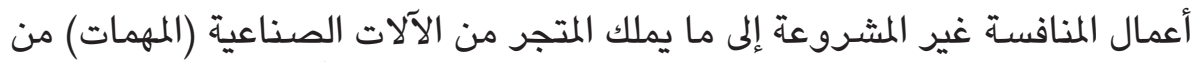

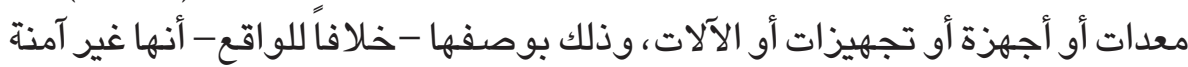

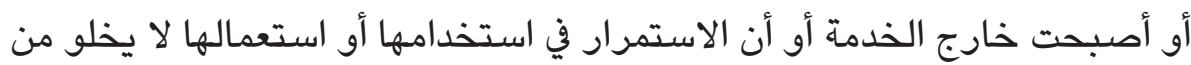
خطر أو إمكانية التسبب بالحوادث أو أو الأضرار.

ومن نافلة القول أن الممارسات المذكورة وما يأخذ حكمها تنطوي على الإسـاءة

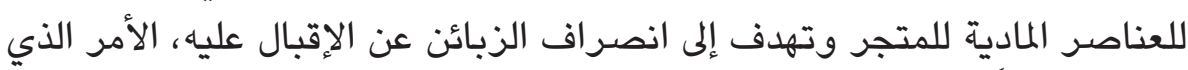

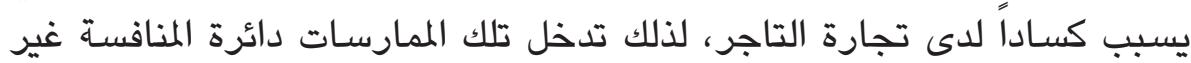

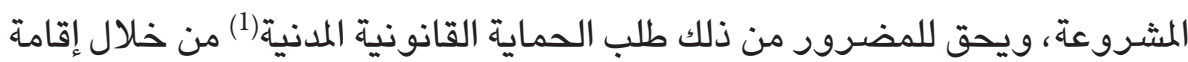
دعوى المنافسـة غير المشروعة متى توافرت شروطها والتي تـتمثل في الخطأ والضرر

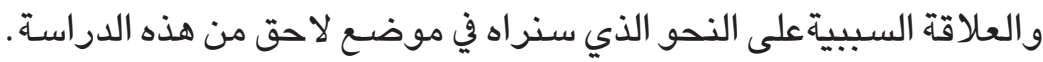
ويحرم القانون القطري هذه الممارسات، إذ تنص المادة 70 منه صراحة على أنه : (رالا

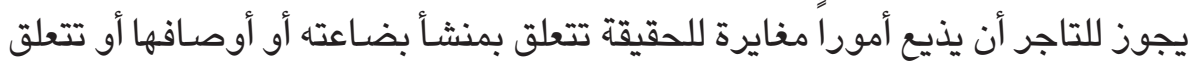

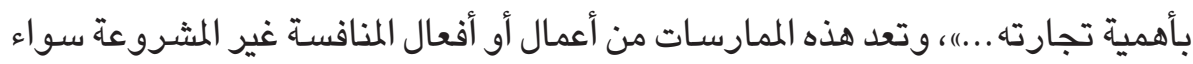

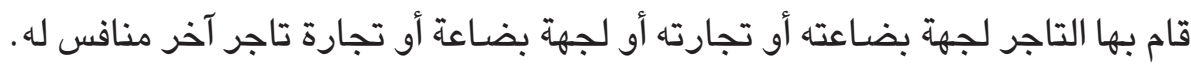

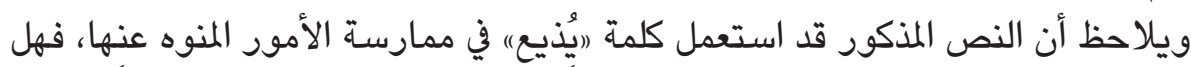

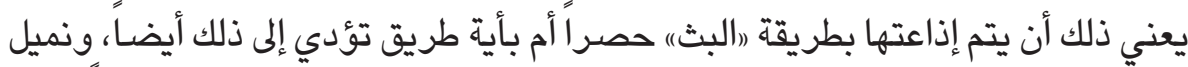

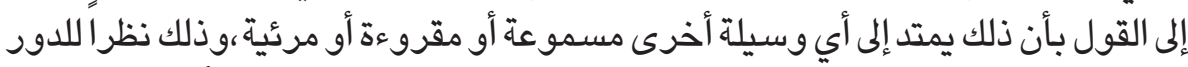

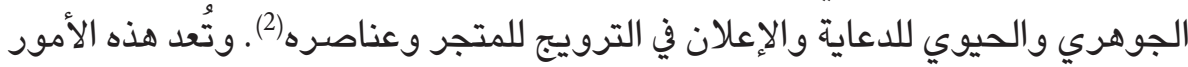

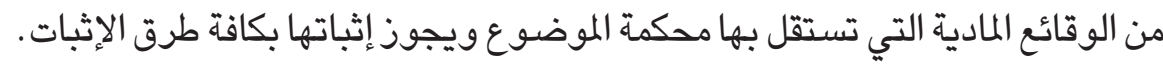

(1) ومن نافلة القول أن أفعال أو أعمال التعدي على العناصر المادية للمتجر -كالسرقة أو الإتلاف - قد تؤدي إلى مساءلة

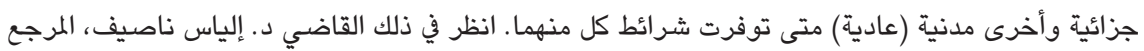

السابق، صنائة وآخري مدنية

(2) د .كوثر سعيد عدنان خالد، حماية المستهلك الإلكتروني، دار الجامعة الجديدة، الإسكندرية 2012، ص 161. 


\section{الفرع الثاني}

\section{صورالمنافسة غير المشروعة التي تتضمن \\ اعتـداءً علـى العناصـر المعنويـة للمتجـر}

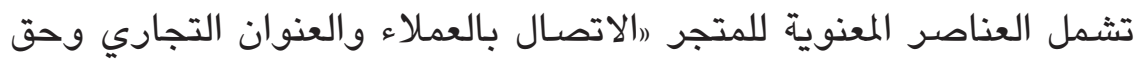

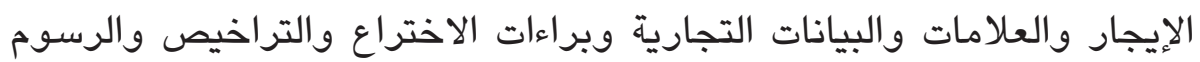

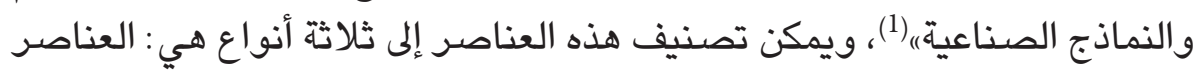

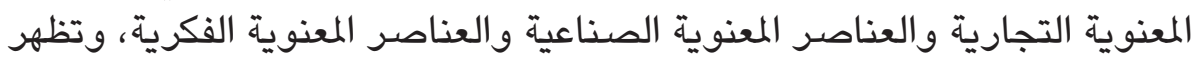

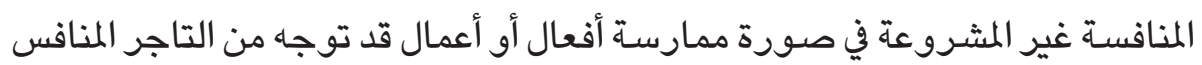

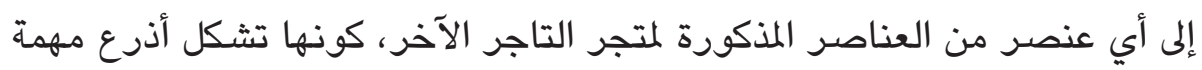

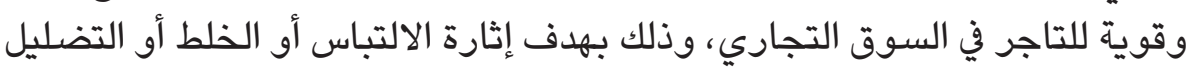

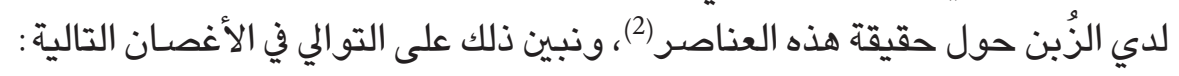

\section{الغصن الأول}

\section{ممارسات المنافسة غير المثروعة التي تتضمن}

\section{اعتداءً على العناصر المعنويـة التجاريـة للمتجر}

تشمل العناصر المعنوية التجارية للمتجر "(عنصر الاتصـال بالعملاء والعنوان

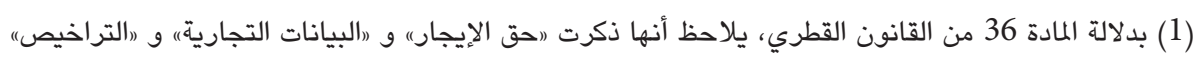

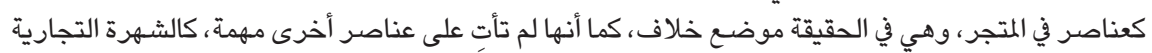

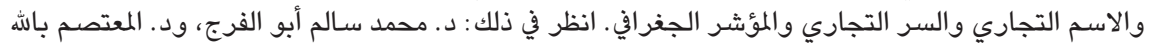

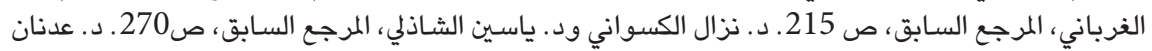

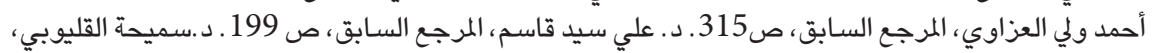

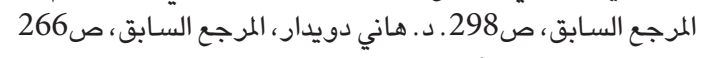

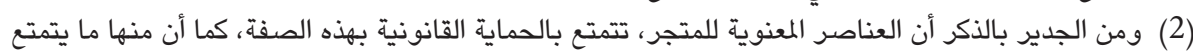

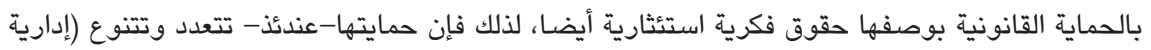

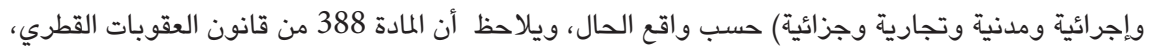

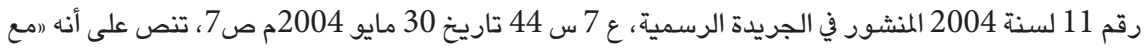

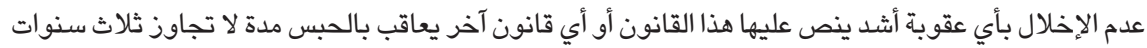

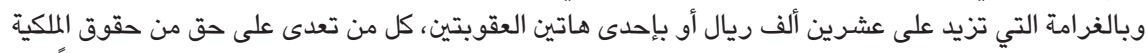

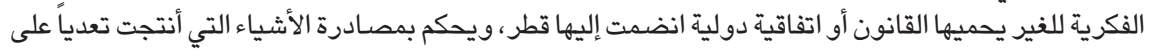

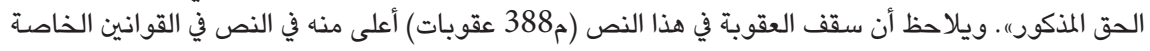

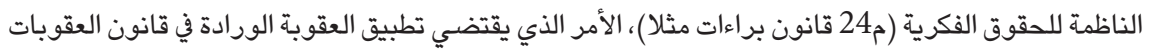
وليس في قانون براءات الاختراع لأنها أعلى. 


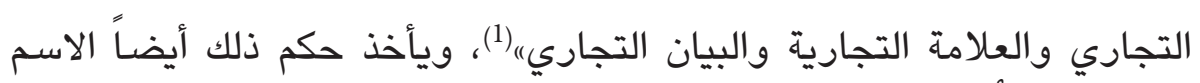

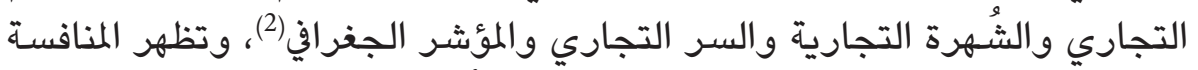

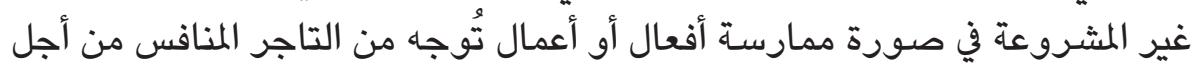

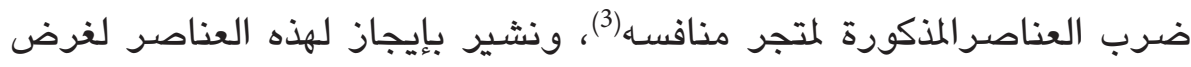

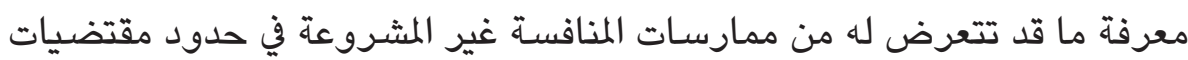
هذه الدراسـة فحسب، وذلك على النحو التالي :

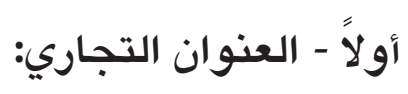

يُعرف القانون القطري العنوان التجاري بأنه : "يتألف ... من اسم التاجر ولقبه أو

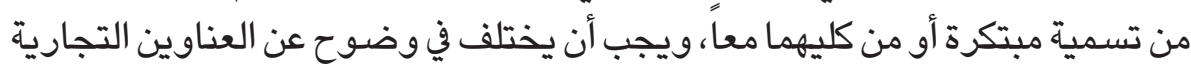

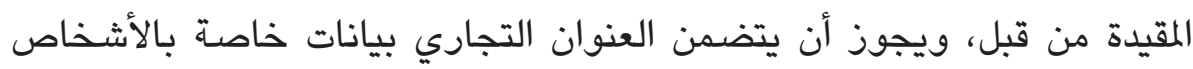

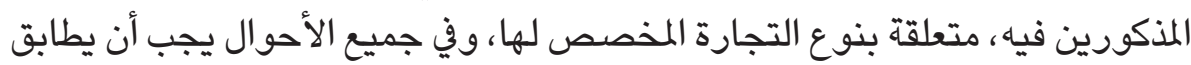
العنوان التجاري الحقيقة وألا يؤدي إلى التضليل أو يمس بـ بالصـالح العام)|(4).

وعليه حتى يعتد القانون بالعنوان التجاري يلزم أن يتوفر فيه الشروط الآتية: 1 - أن يتكون من اسم التاجر ولقبه أو من تسمية مبتكرة أو من كليهما معاً. 2 - أن يكون مميزاً، أي له ذاتية خاصة تميزه عن العناوين التجارية المسجلة من قبل. 3 - أن يكِِن مطابقاً للحقيقة، أي أن يكون اسم أو لقب التاجر الوارد في تكوينه صحيحاً وموافقاً للواقع.

4 غيره من العناوين المستعملة في النشاط التجالي التخاري.

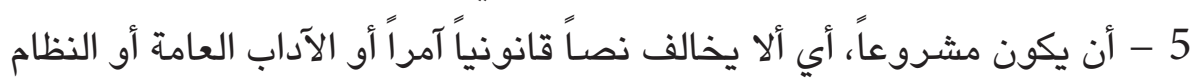

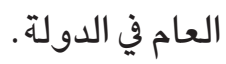

(1) بدلالة المادة 36 من القانون القطري.

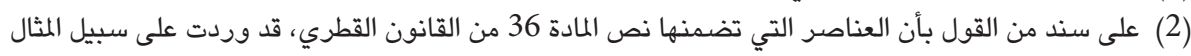

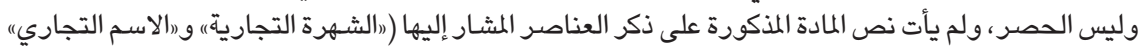

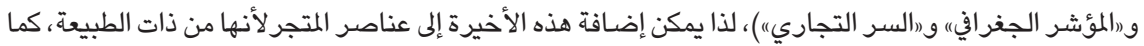

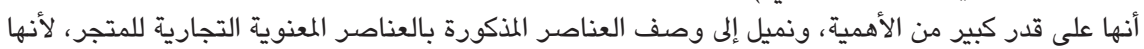
ترتبط بالمتجر لغرض تسوير من الاهمية، ونتهيل أو إلى وضائعه أو خدماته.

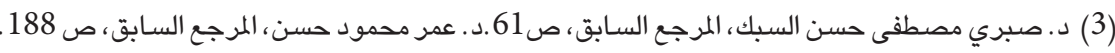
(4) المادة 60 من القانون المذكور ، وتختلف عناصر العنوان التجاري باختلاف نوع التاجر (التاجر الفرد والتاجر الشركة). 
ويُعد العنوان التجاري عنصراً معنوياً في المتجر(1)، ويتمتع صاحب العنوان

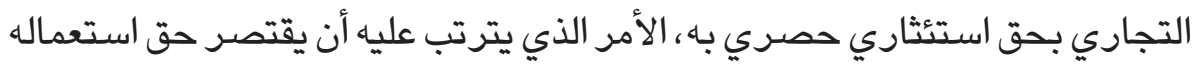

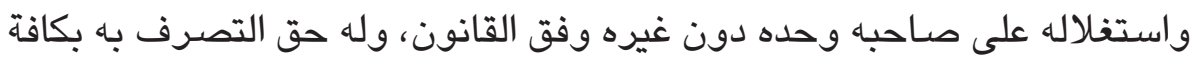

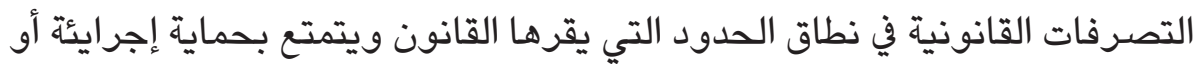

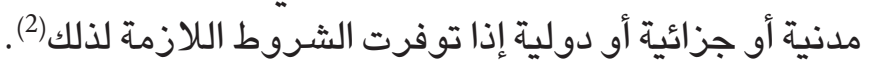

ويقوم العنوان التجاري بوظيفة أساسية تتمثل في تمييز التاجر عن غيره من

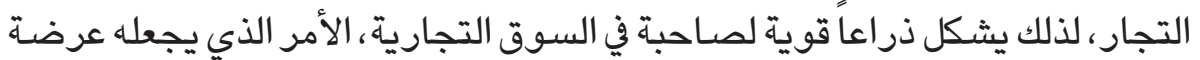

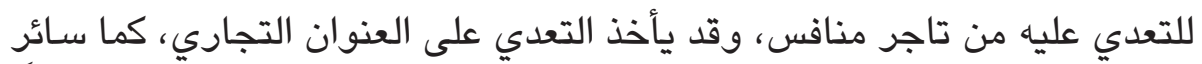

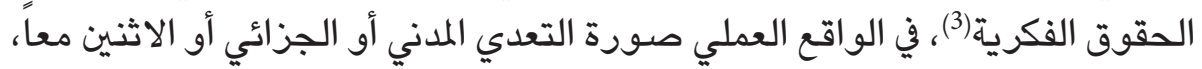

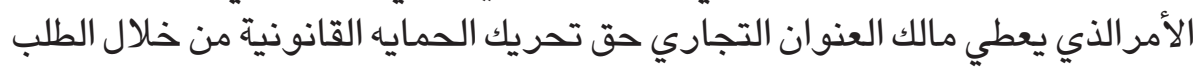

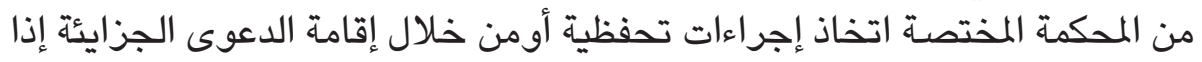

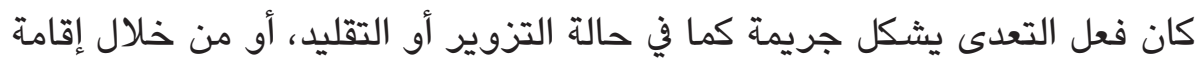

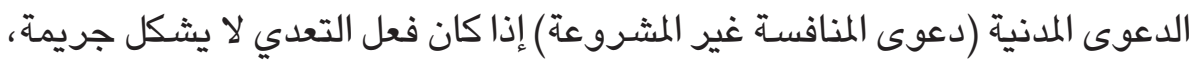

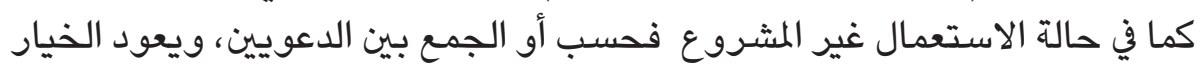

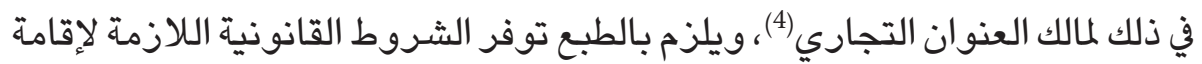

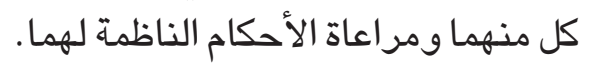

ويوفر القانون القطري الحماية القانونية للعنوان التجاري وذلك بموجب المادة 68

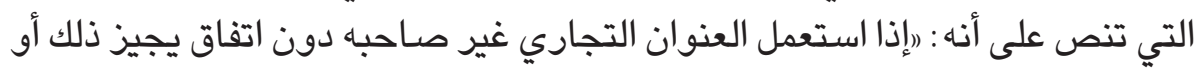

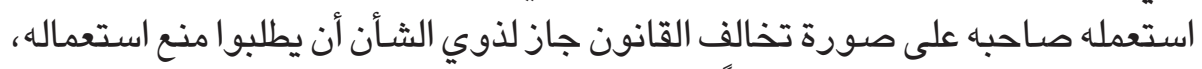

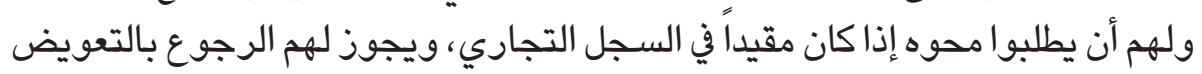

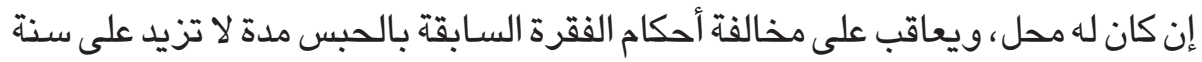

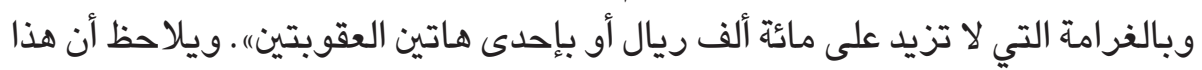

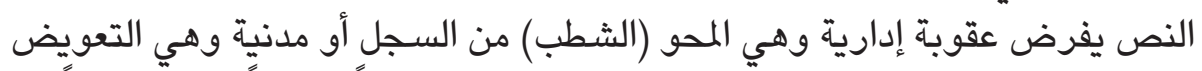

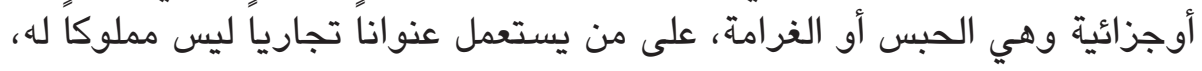

$$
\text { (1) المادة } 36 \text { من القانون المذكور ، وقد سبقت الإشارة إليها. }
$$

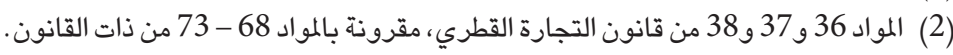

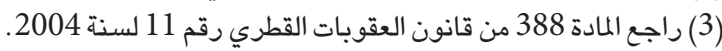

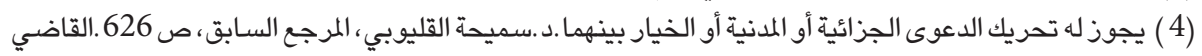

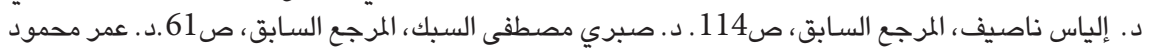

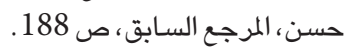


وكذلك على من يستعمل عنوانه التجاري استعمالاً بطريقة مخالفة للقانون، والذي يهمنا

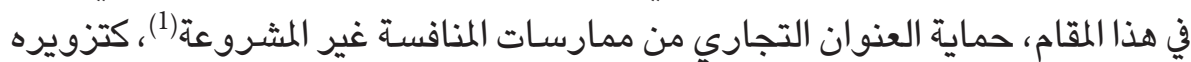

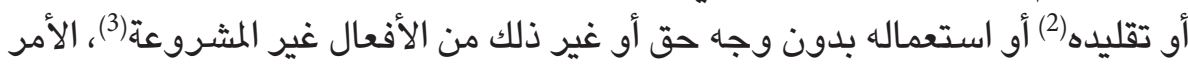

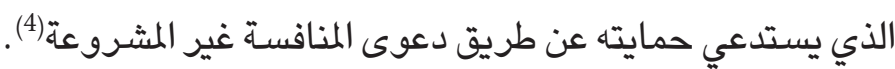
ثانياً - الاسم التجاري:

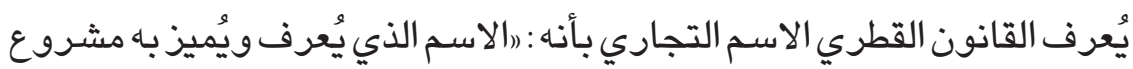

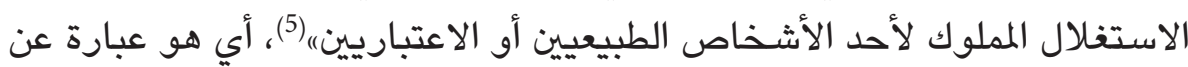

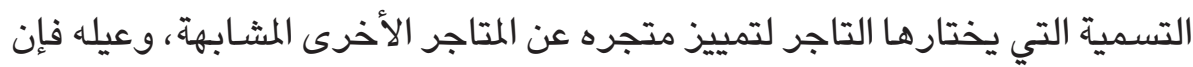

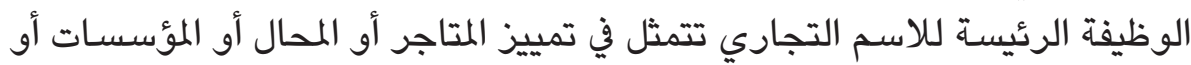

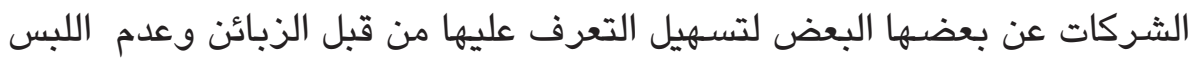

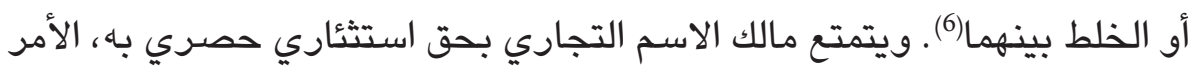
الذي يقتضي من الغير احترام ذلك ويعطي مالكه حق استعماله واستغلاله وتأجيره

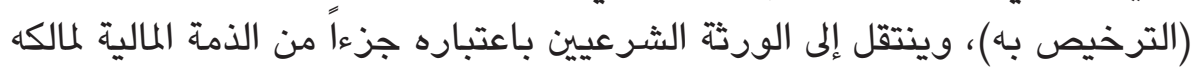

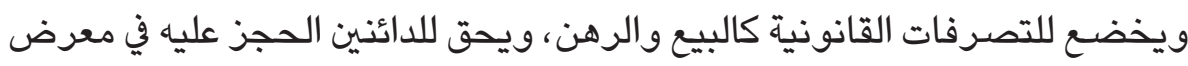
استيفاء الديون التي تترتب لهم على مالكه.

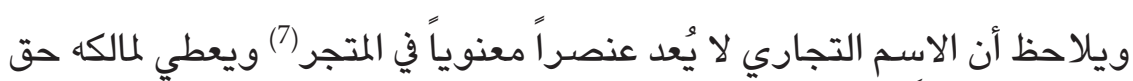

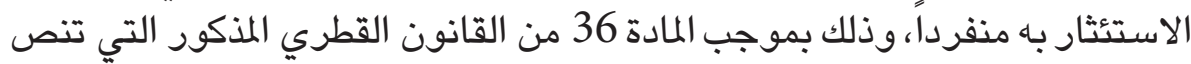
على أنه : "يكون لمالك الاسم التجاري الحق في منع الغير من استعماله أو استعمال

(1) (1) بدلالة المادة 68-73 من قانون التجارة القطري.

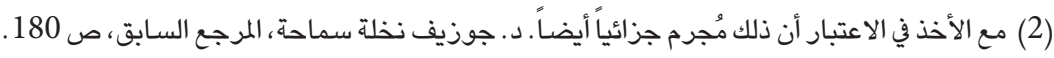

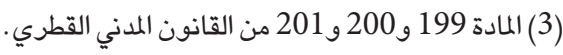

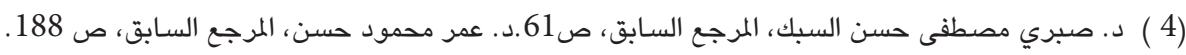

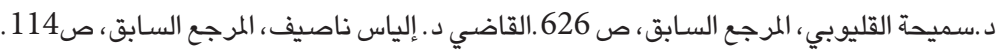

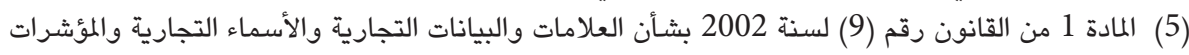

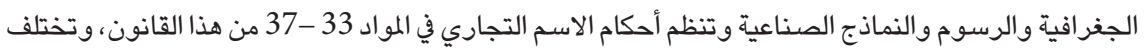

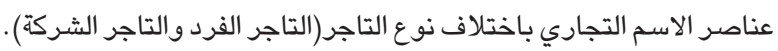

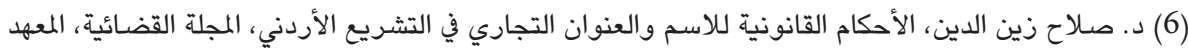

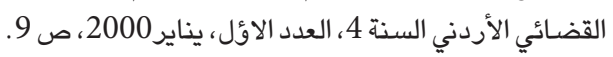

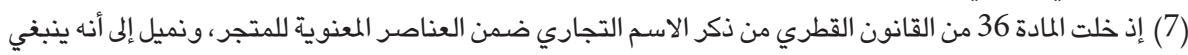

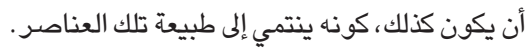


أي إثـارة مشابهة له يكون من شأنها تضليل الجمهور أو إثارة اللبس لديه في شـأن

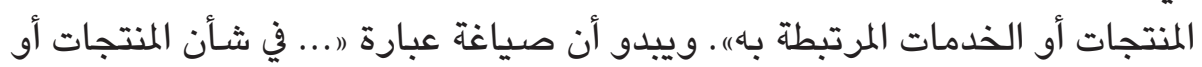

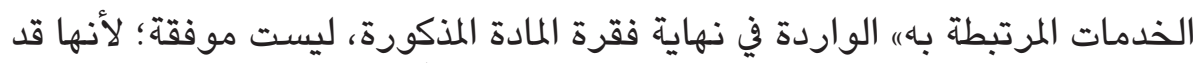

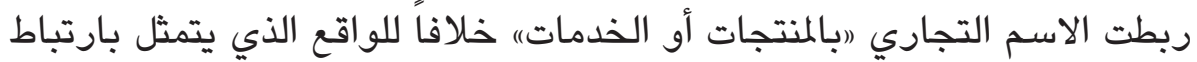

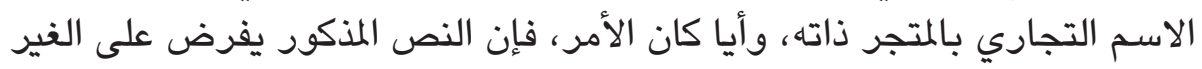

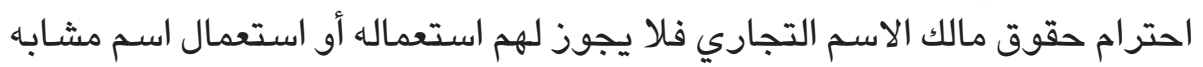

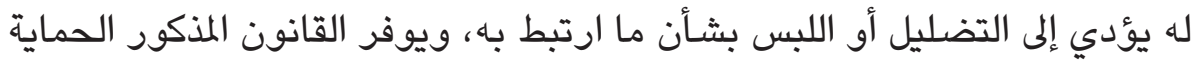

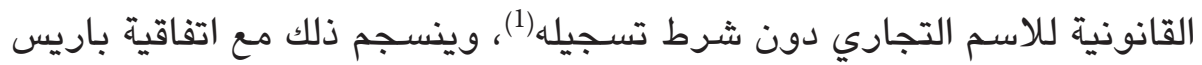

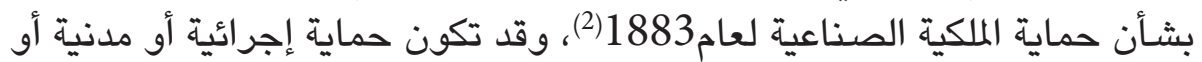

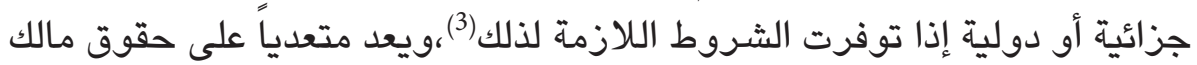
الاسم التجاري كل من يقترف فعلاًمن الأفعال الآتية(4): 1 - تزوير أو تقليد الاسم التجاري بطريقة تدعو إلى تضليل الجمهور أو إثارة اللبس لديه. 2 - استعمل -بسوء قصد- الاسم التجاري المقلد أو المزور.

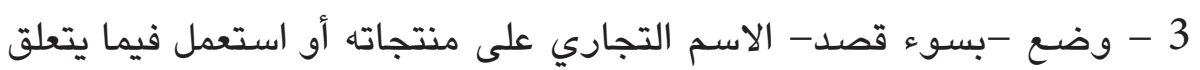

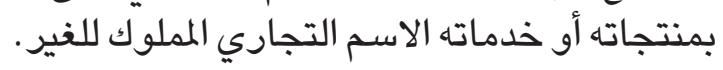
4 - بيع أو عرض للبيع أو للتداول أو حاز بقصد البيع -بغير حق- منتجات عليها الاسـم التجاري المزور أو المقلد.

5 - قدم أو عرض خدمات مستغلاً الاسم التجاري، بغير حق مع علمه بذلك. ويلاحظ أن هذه الأفعال ترتب المسؤولية الجزائية إذا تم اقترافها بسوء النية،

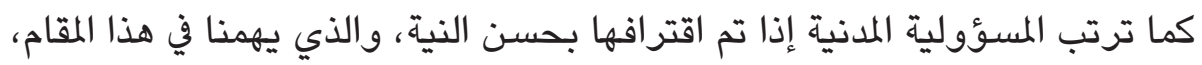

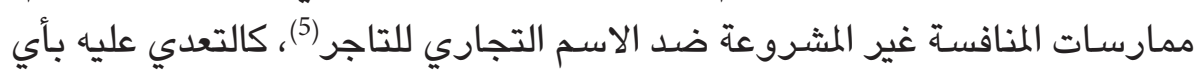

$$
\begin{aligned}
& \text { (1) المادة } 33 \text { من ذلك القانون. }
\end{aligned}
$$

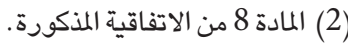

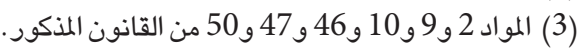

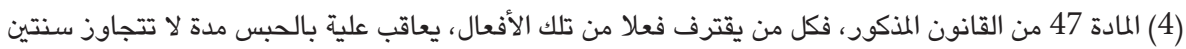

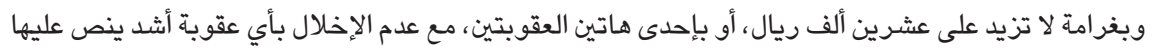

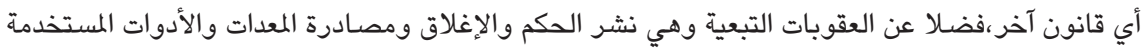

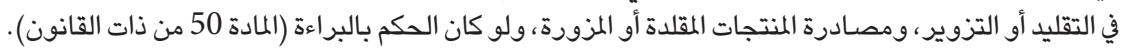
(5) د. أكثم الخولي، الموجز في القانون التجاري، ج1، مكتبة سيد وهبة، الإسكندرية 1970، ص ص 1974 ، د. د. صبري

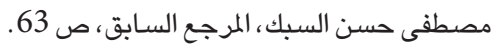


فعل من الأفعال المذكورة أو أي فعل آخر غير مشروع (1)، الأمر الذي يستدعي حمايته

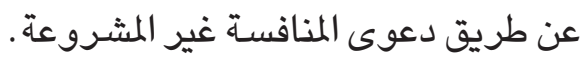
ثالثاً - العلامة التجارية:

يُعرف القانون القطري العلامة التجارية بأنها : اكل إثـارة ظاهرة تقبل الإدراك

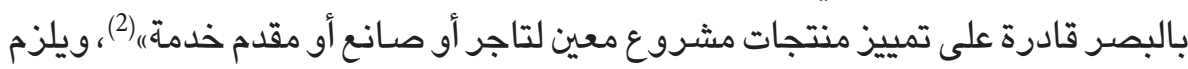

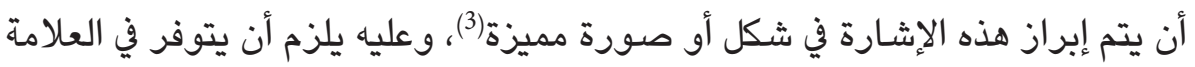

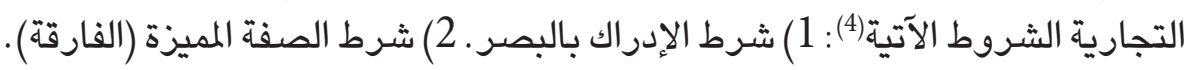
3) شرط الشكل المميز. 4) شرط الجدة. 5) شرط المشروعية. 6) شرط الآترة التسجيل. وتَكعب العلامة التجارية رأس حربة للمتجر كونها تُشكل جواز سفر لمرورد

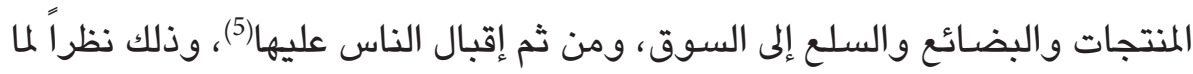

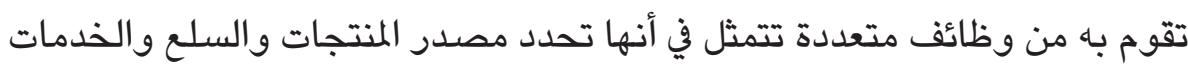

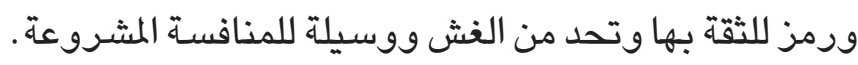

وتُعد العلامة التجارية عنصراً جوهرياً في المتجر (6) ويتمتع مالكهابحق استئثاري

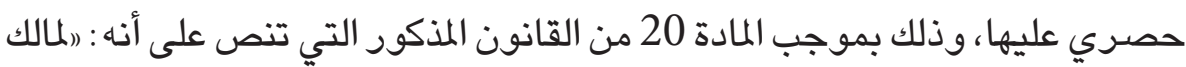

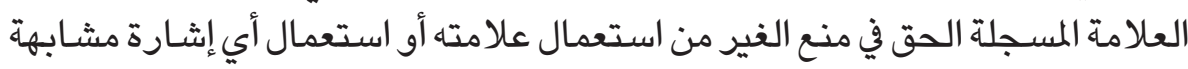

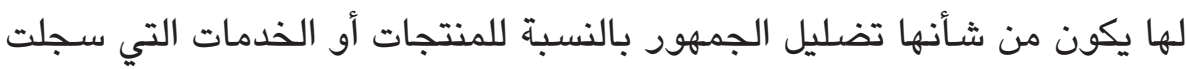

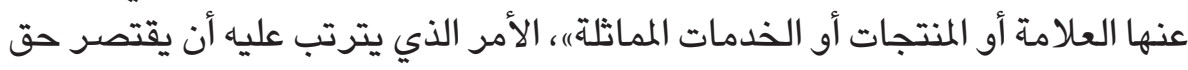

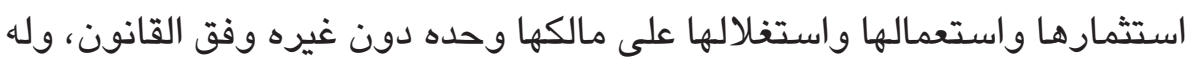
حق التصرف بها بكافة التصرفات القانونية في نطاق الحدود التي يقرها والقال القانون.

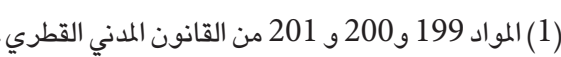

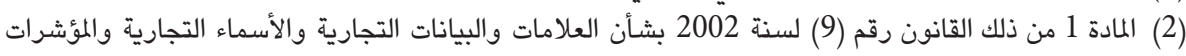

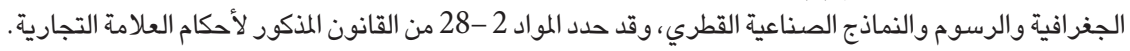

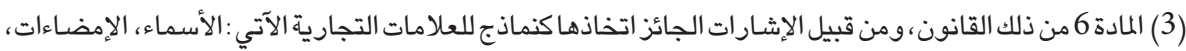

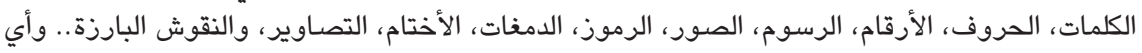

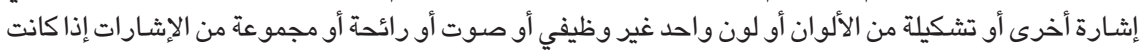

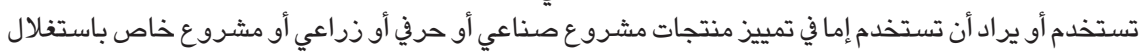

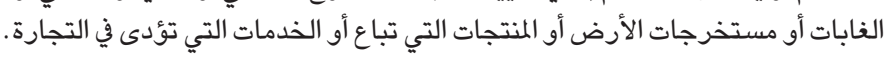

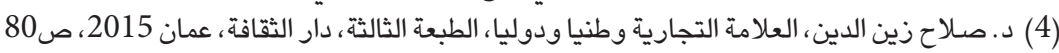

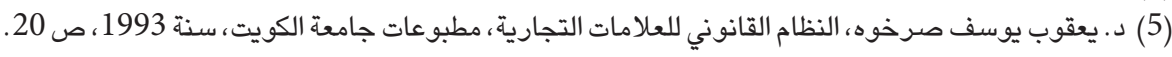

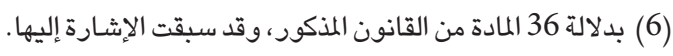


ويعد متعدياً على حقوق مالك العلامة التجارية كل من يقترف فعلاً من الأفعال الآتيـة (1): (1) 1- تزوير أو تقليد علامة تجارية مسجلة بطريقة تدعو إلى تضليل الجمهور أو إثارة اللبس لديه. 2 - استعمل -بسوء قصد- علامة مقلدة أو مزورة.

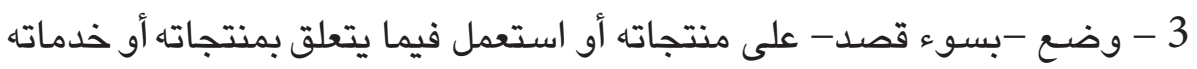
علامة مملوكة للغير. 4 - بيع أو عرض للبيع أو للتداول أو حاز بقصد البيع -بغير حق- منتجات عليها علامة مزورة أو مقلدة. 5 - قدم أو عرض خدمات مستغلاً علامة مسجلة بغير حق مع علمه بذلك.

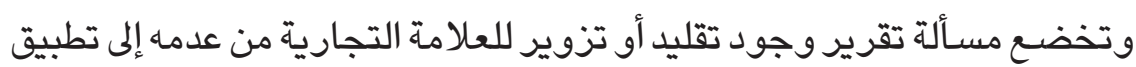
المعايير الآتية)(2) (2)

الأول : العبرة بأوجه التشابه بين العلامتين لا بأوجه الاختلاف. والثاني: العبرة بالمظهر العام في العلامتين لا بالعناصر الجزئية. والثالث: العبرة بتقدير المستهلك العادي لا المستهلك الفطن أو المستهلك الغافل. والرابع: عدم النظر إلى العلامتين بالتجاور بل الواحدة تلو الأخرى. والخامس: أن يؤدي فعل التزوير أو التقليد للعلامة التجارية إلى تضليل الزبائن. ويلاحظ أن العلامة التجارية من أكثر عناصر الملكية التجارية عرضـة للتعدي

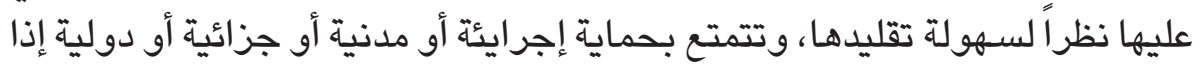

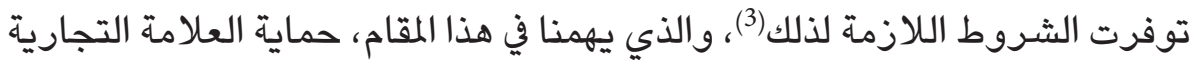

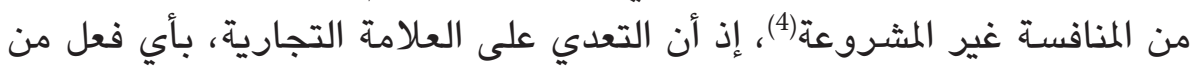

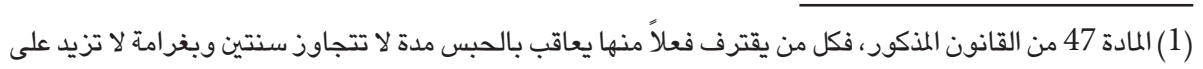

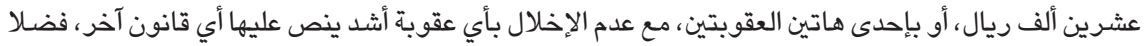

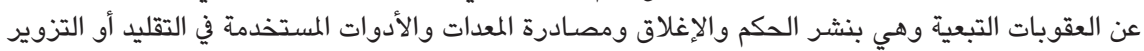

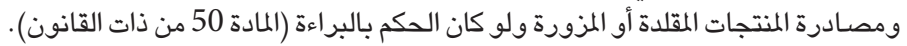
(2) د. نعيم جميل صالح سلامة،، المرجع السابق، ص325.

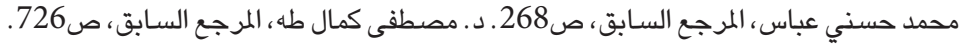

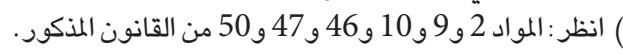

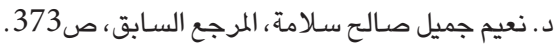


الأفعال المذكورة أو أي فعل آخر غير مشروع (1)، يستوجب المسؤولية القانونية

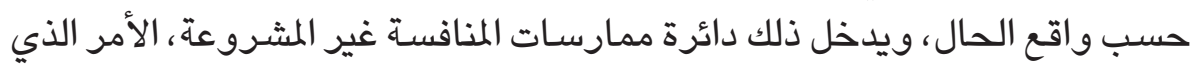

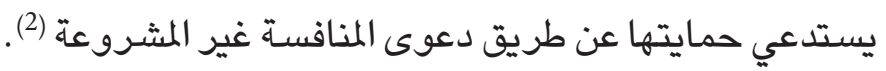
رابعاً - المؤشر الجغرافي:

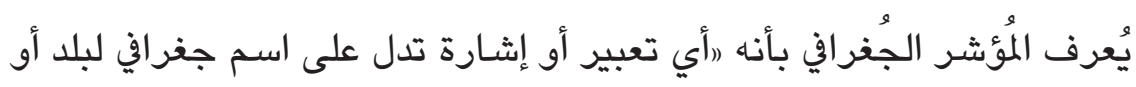

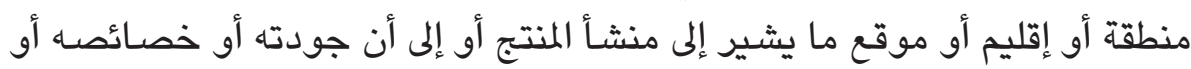

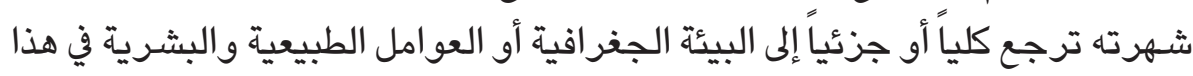

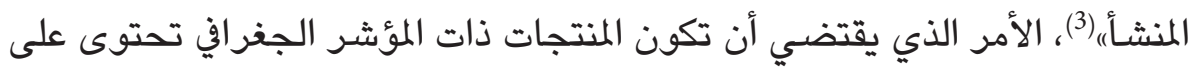

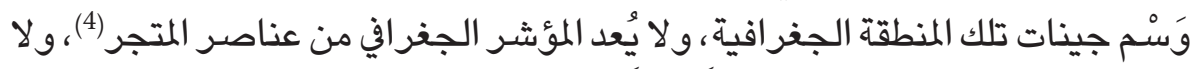

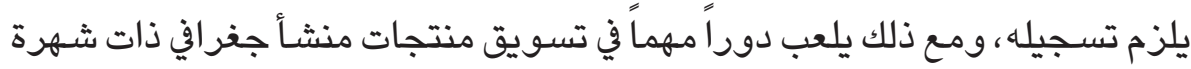

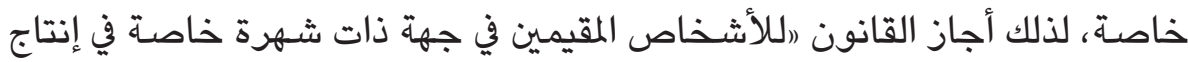

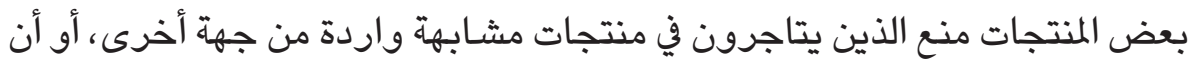

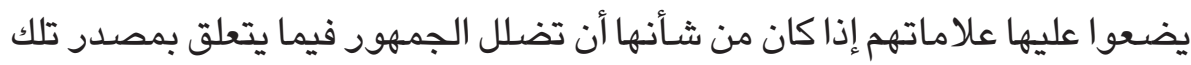

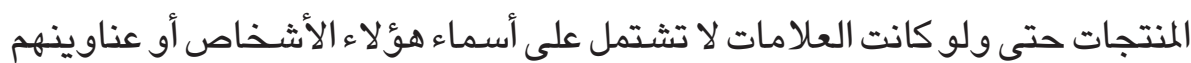
ما لم تتخذ التدابير الكفيلة بمنع أي لبس)|(5). ويتمتع المؤشر الجغرافي بالحماية القانونية، لدى الاعتداء عليه كتزويره أوتقليده

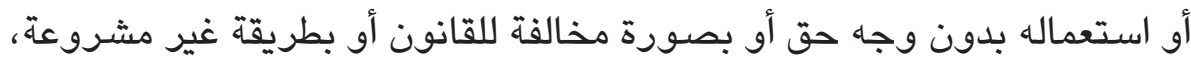
والفيصل في ذلك هو نية المعتدي، فإن ساءت تلك النية ، نكون أمام فعل مجرم جزائياً،

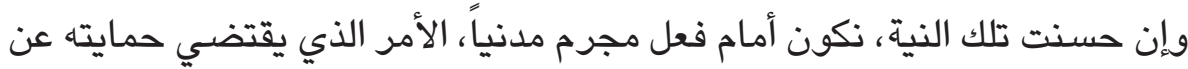

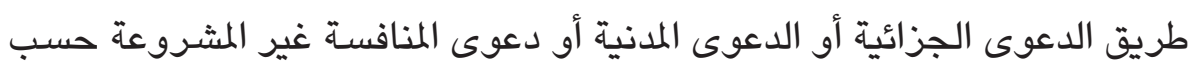
فعل التعدي.

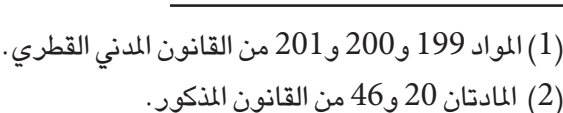
(3) المادة 1 من القانون رقم (9) لسنة 2002 بشأن العلامات والبيانات التجارية والأسماء التجارية والمؤشرات

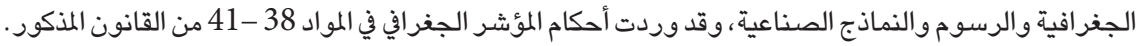

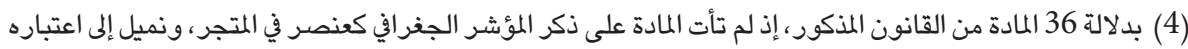




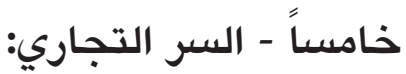

يُعرف القانون القطري الأسرار التجارية بأنها: ،المعلومات التي في مجموعها أو

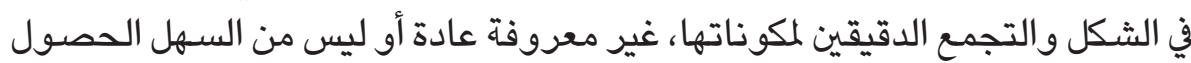

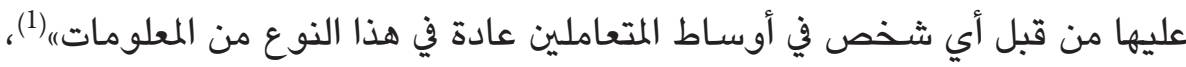

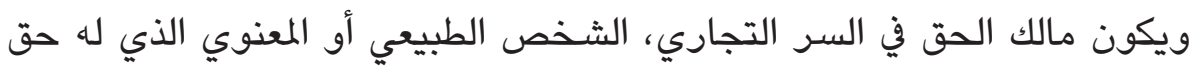

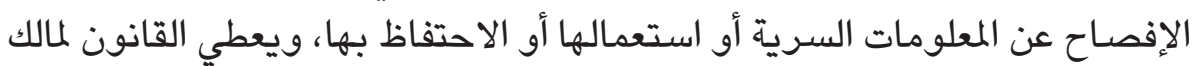

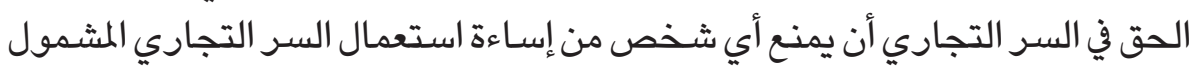

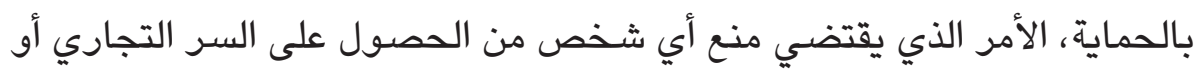

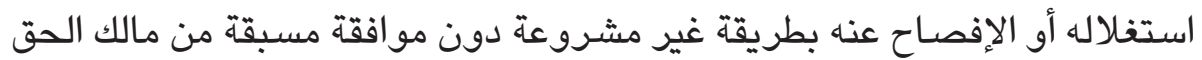

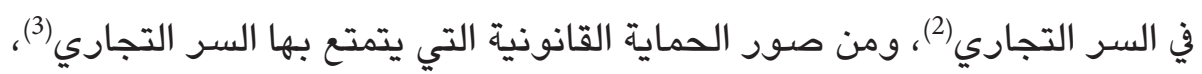
الحظر على أي شخص القيام بأي فعل من الأفعال الآتية(4): 1- الإخلال بالعقد المبرم بين مالك الحق في السر التجاري والشخص المستثمر أو المستخل له. 2- الإخلال بسرية المعلومات التجارية أو الحث على الإخلال بها. 3- الحصول على الأسرار التجارية باستعمال الطرق الاحتيالية. 4- الحصول على الأسرار التجارية من طرف ثالث إذا كان يعلم أو كان بمقدوره أن يعلم بأن حصوله عليها كان بطريقة تتنافى والممارسات التجارية النزيهة. ويحق لمالك الحق في السر التجاري أو لخلفه المطالبة بالتعويض عما لحقه من ضرر نتيجة تعدي الغير على هذا السر أو إسـاءة استعماله، كما يحق له ذلك الك حال إتيان

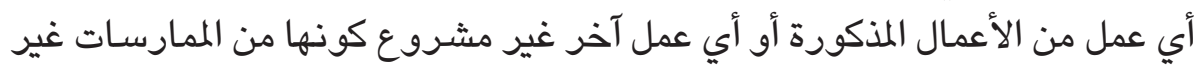

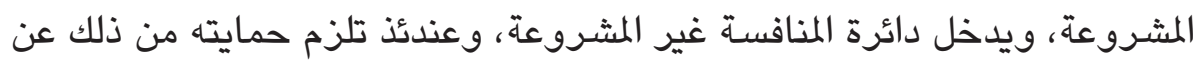

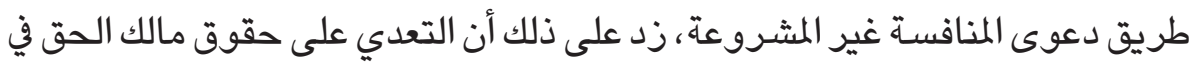
السر التجاري يستوجب المسؤولية الجزائية (5). (1) المادة 1 من القانون رقم (5) لسنة 2005 بشأن حماية الأسرار التجارية.

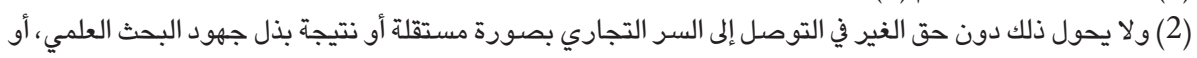

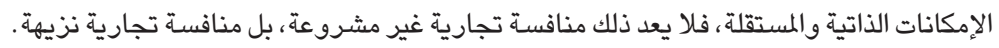
(3) Dr. Mohamed Salem Abou El Farag, ibid, 2009. p. 128. 


\section{سادساً - البيانات التجاريـة:}

يقصد بالبيانات التجارية ما يجب وضعه من معلومات أو مواصفات أو

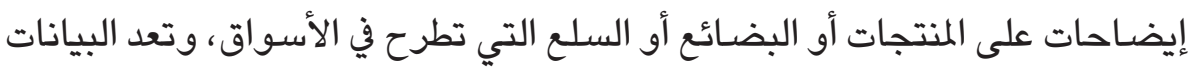

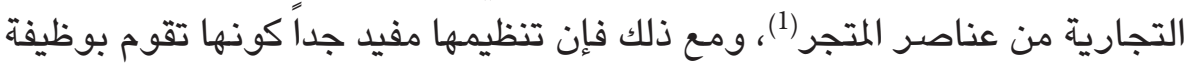

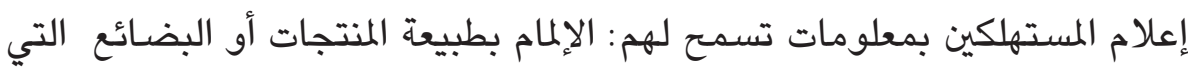

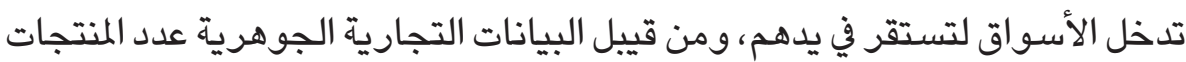

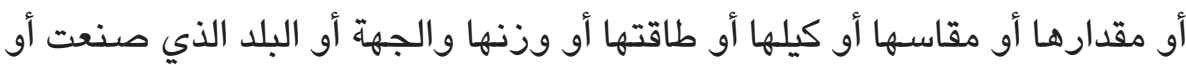
أنتجت فيه المنتجات وطريقة صنعها أو إنتاجها والعناصر الداخلة في تركييها وبيانات الصانع أو المنتج ووجود براءات اختراع أو حقوق ملكية فكرية أخرى أو أي امتيازات أو جوائز أو شـهادات تقدير (2).

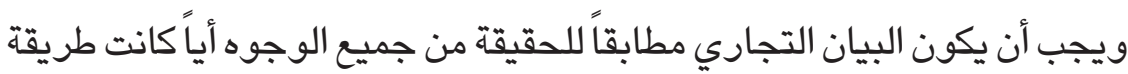

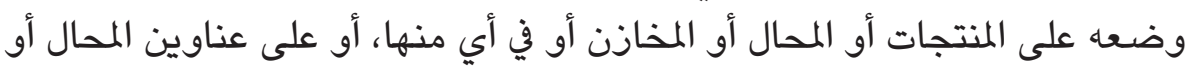

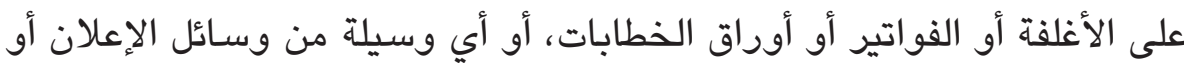

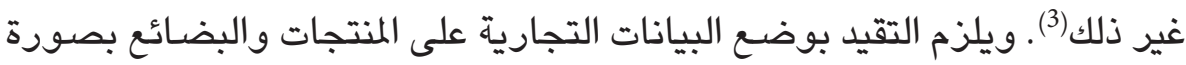

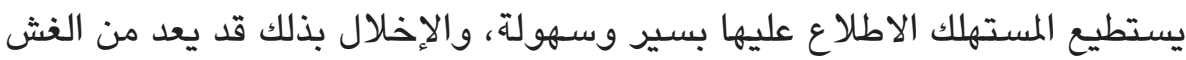

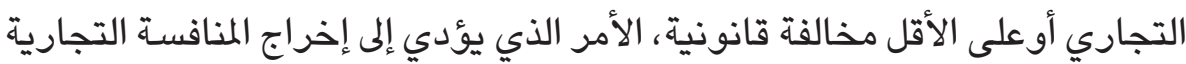

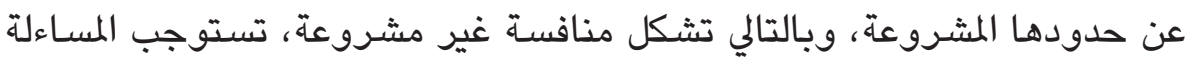
القانونية حسب المقتضى القانوني.

\section{سابعاً - الاتصال بالعملاء:}

يُثير "الاتصال بالعملاء) جدلاً كبيراً لجهة المعنى والمبنى والأهمية، ولا مجال

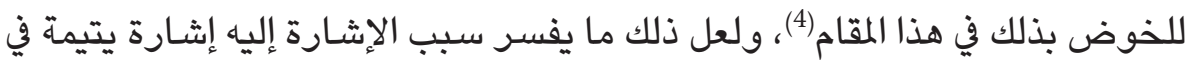

(1) بدلالة 36 المادة من القانون المذكور ، وقد سبقت الإثـارة إليها، ولكنها ليست من حقوق الملكية الفكرية.

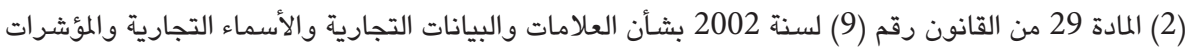

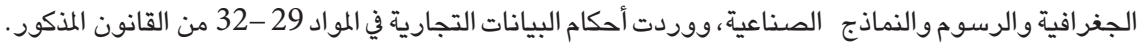

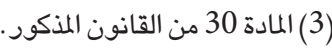

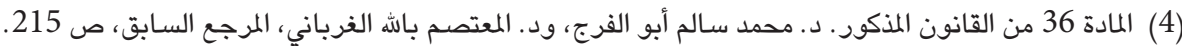

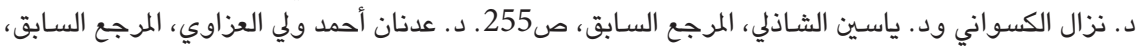

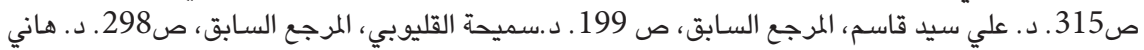

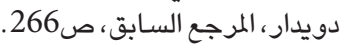


المادة 36 من القانون القطري في معرض تعداد العناصر المعنوية للمتجر(1)، في حين تم

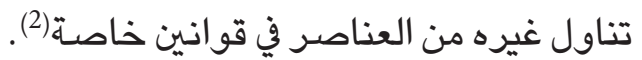
وصفوة القول أن فكرة تأسيس المتجر منذ البداية تقوم على هاجس جذب الزبائن

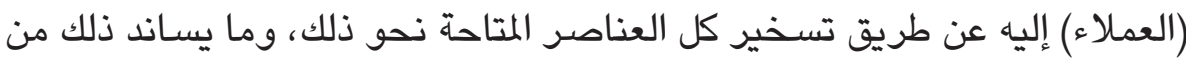

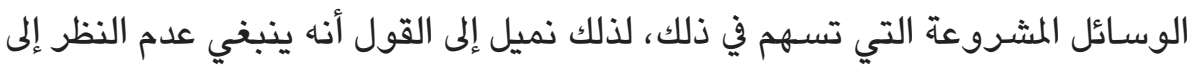

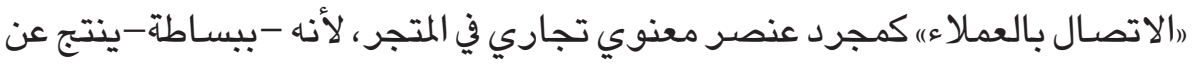

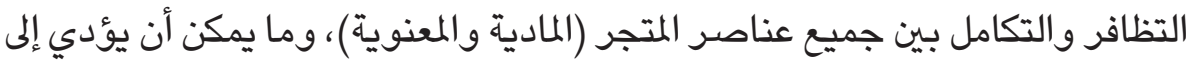

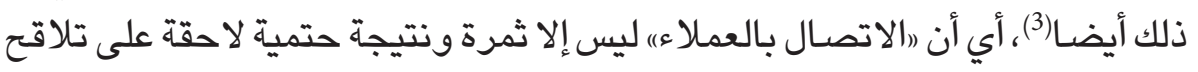
تلك العناصر ، ويبدأ بالوجود بعدها (أو في الأقل معها) وليس سـابقا عليها، الأمر الذي وني

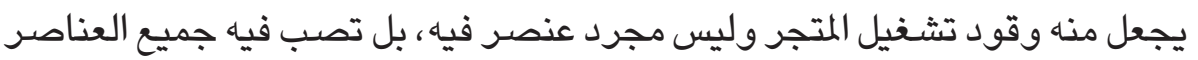

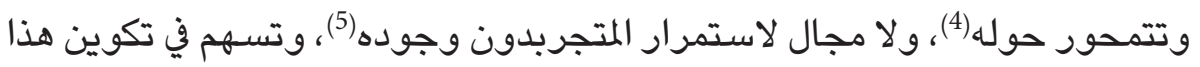

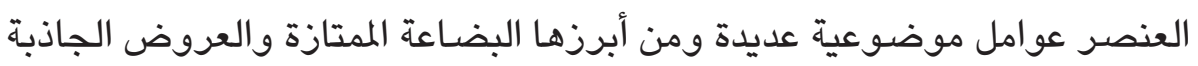
والخدمة الراقية والموقع المتميز والدعاية المحترفة . وعليه يشكل "الاتصـال بالعملاع)، بصرف النظر عن معناه أو مبناه أو أهميته

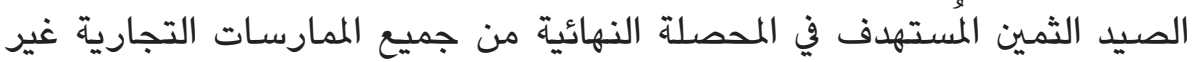

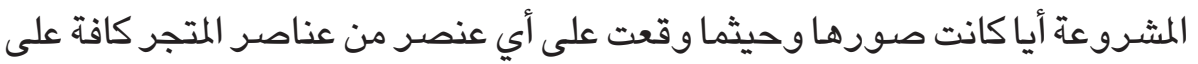

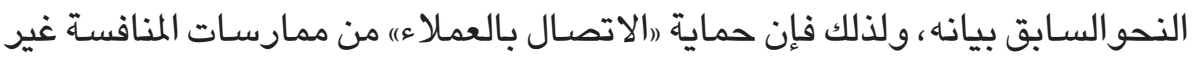

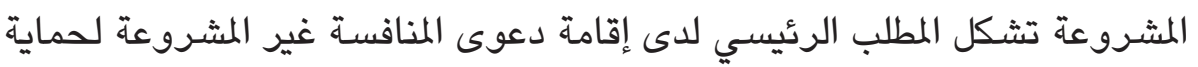

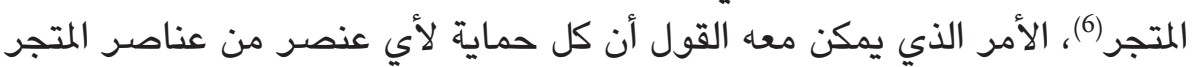

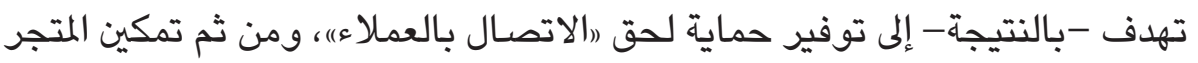
(1) ويبدو القصد من ذلك ترك أمره للفقه، وقد سبقت الإشارة إلى نص المادة المذكورة غير مرة. د. محمد سالم أبو الفرج

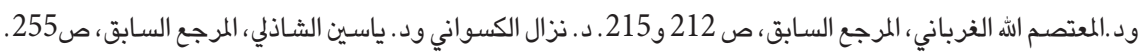

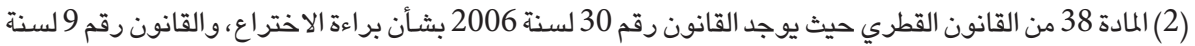

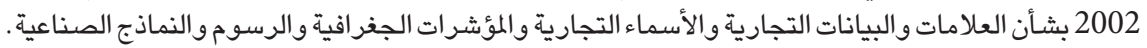

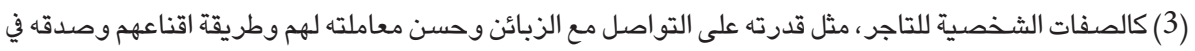

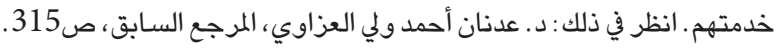
(4) د. سميحة القليوبي، المرجع السابق، ص306.

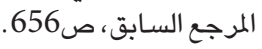

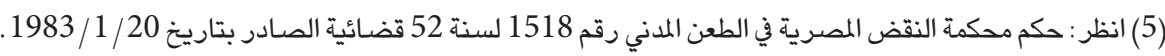

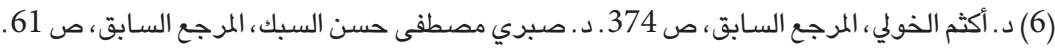


من الاحتفاظ بعملائه واجتذاب المزيد منهم، وبالتالي صد أو إفشـال أو معالجة أي أي

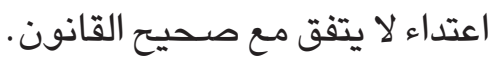

\section{ثامناً - السمعة (الشهرة) التجاريـة:}

تُثير "السمعة التجارية،) أيضًاً شيئًاً من الجدل لجهة استقلاليتها عن عناصر

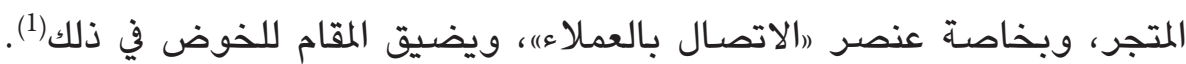

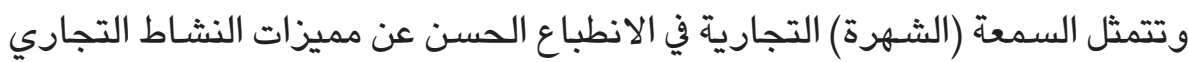

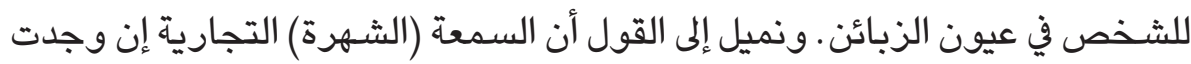

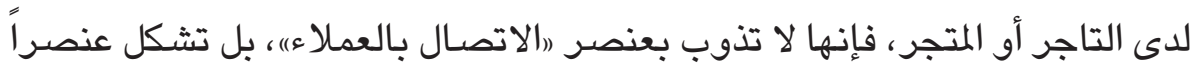

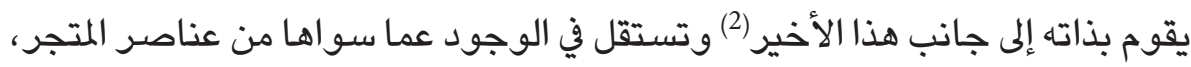

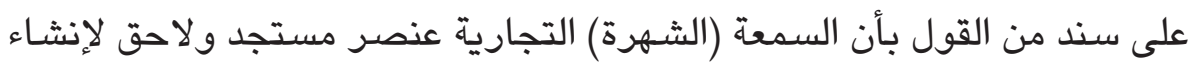

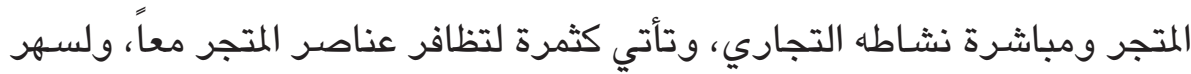

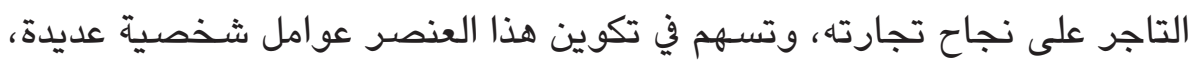

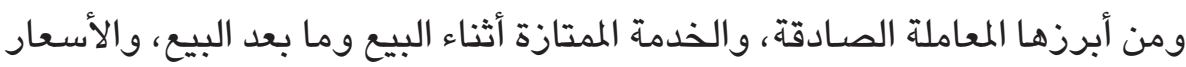

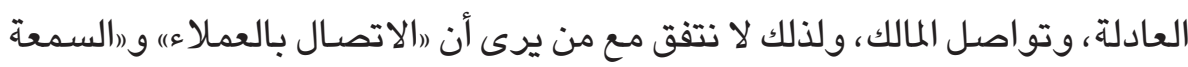

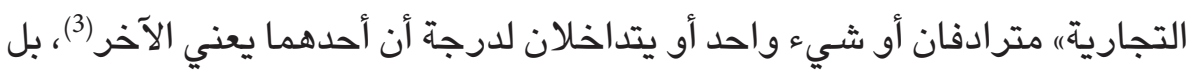

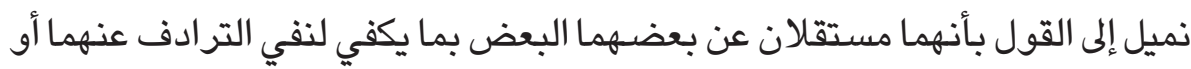

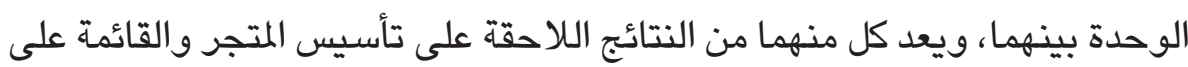

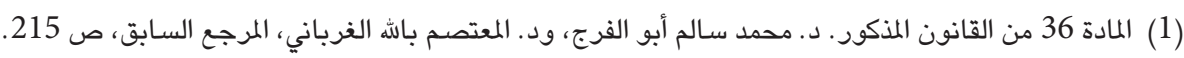

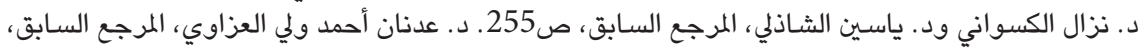

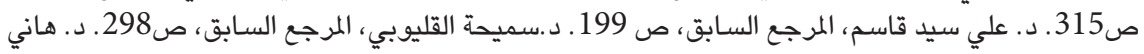

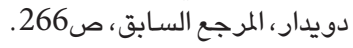

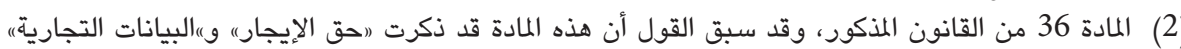

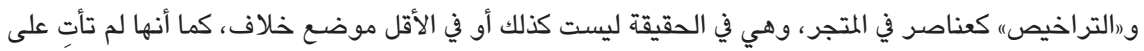

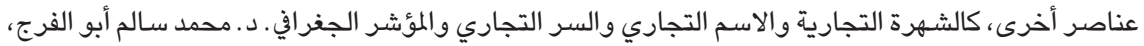

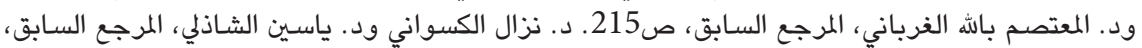

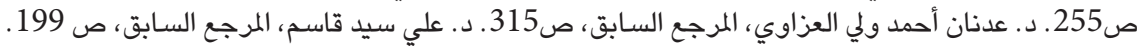

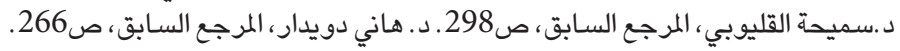

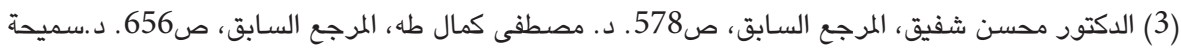

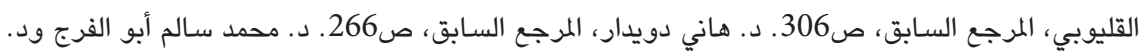
المعتصم باله الغرباني، المرجع السابق، ص ص 212 و215. 
عناصره المادية والمعنوية مجتمعة وظهورهما - في الواقع - لا يتم بالتزامن التام، بل يقع على التوالي، لذلك ينبغي النظر إليهما على أنهما الثمار التي يقطفها المتجر الناجح بعد مباشرة نشاطه التجاري، ويتميز بهما عن غيره من المتاجر الأخرى. وتوجه ممارسـات المنافسة غير المشروعة في هذه الحالة، في صورة أفعال أو أعمال من التاجر المنافس إلى (الشـهرة التجاريةّ)، التي قد يتمتع بها التاجر الآخر كما متجره،

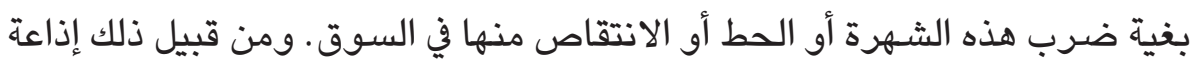
قول كاذب بأنه تم الحصول على تلك الشهرة عن طريق الغش أو التدليس أو التضليل

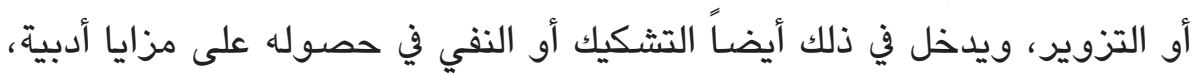

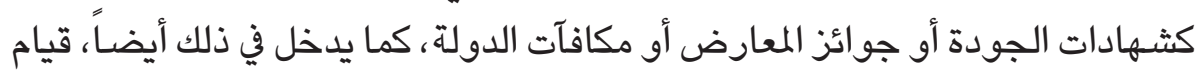

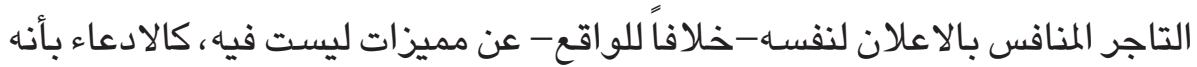
حائز لمرتبة أو شهادة أو مكافأة ليست متوفرة لدى التاجر الآخر ، أو الزعم أن زبائنه

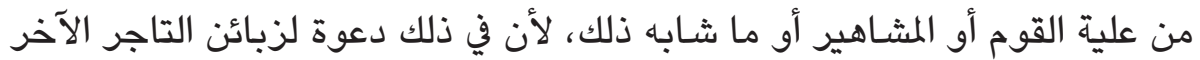

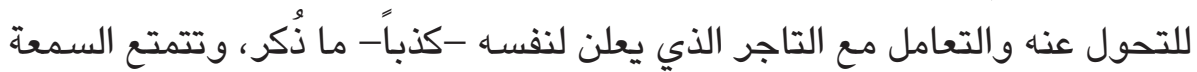

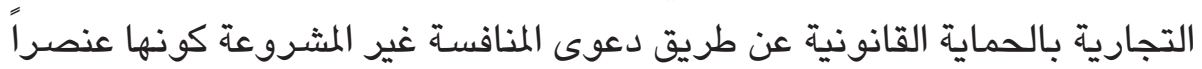

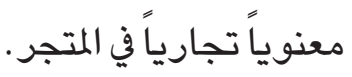

وفي هذا السياق تنص المادة 70 من القانون القطري على أنه : (الا يجوز للتاجر ...

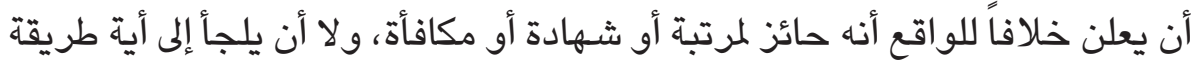

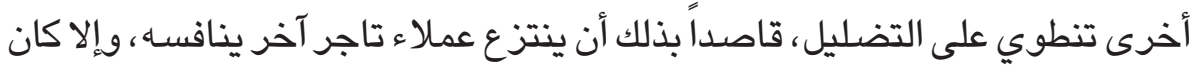

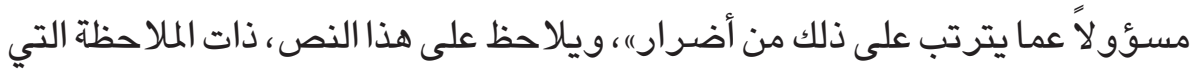

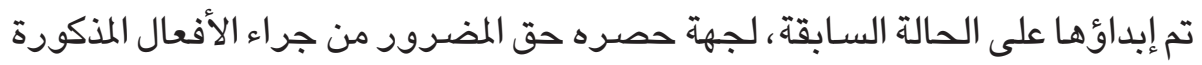

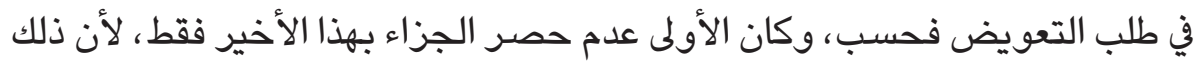

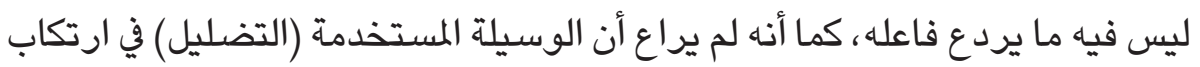

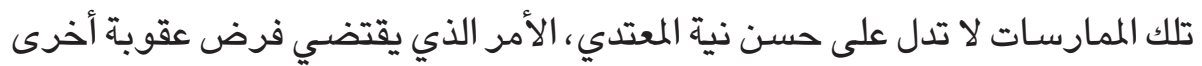
بجانب التعويض كفرض عقوبة جزائية (تبعية) كالغرامة أيضا أو أي عقوبة أخرى لإنى

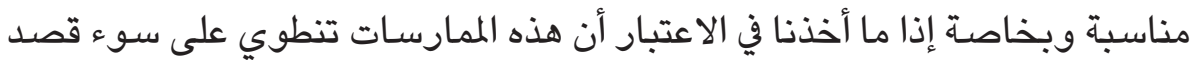
أو نية سيئة. 


\section{الغصن الثاني}

\section{ممارسات المنافسة غير المشروعة التي تتضمن \\ اعتداءً على العناصر المعنويـة الصناعية للمتجر}

تتمثل العناصر المعنوية الصناعية للمتجر في "براءات الاختراع والرسوم الصناعية والنماذج الصناعية)|(1)، ويمكن أن يضاف إلى هذه العناصر أيضاً عناصر

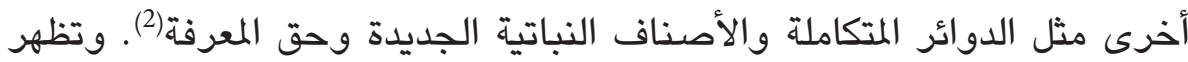

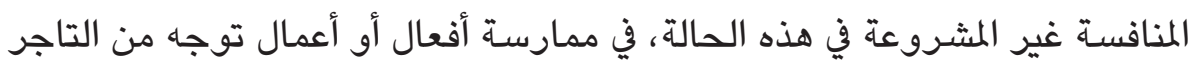
المنافس إلى العناصر المعنوية الصناعية لمتجر التاجر الآخر . ونشير فيما يلي بإيجاز لهذه العناصر لغرض معرفة ما تتعرض له من ممارسـات

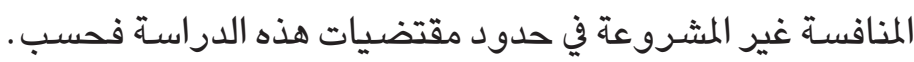

$$
\text { أولاً - براءة الاختراع: }
$$

يُعرف القانون القطري الاختراع بأنه : رالشيء الجديد الذي يكون منطوياً على

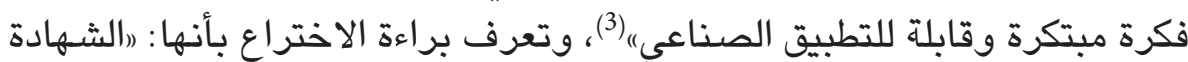

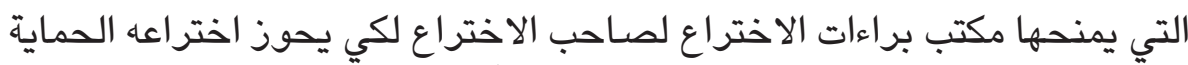

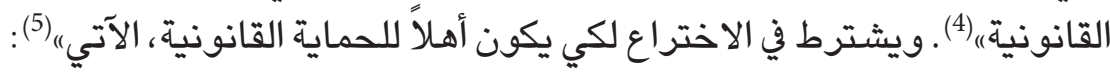

$$
\text { 1- أن يكون الاختراع جديداً. }
$$

2 - أن ينطويً الاختراع على فكرة مبتكرة. 3 - أن يكون الاختراع قابلاً للتطبيق الصناعي.

(1) المادة 36 من القانون القطري. د. محمد سالم أبو الفرج، ود. المعتصم باله الغرباني، المرجع السابق، ص 215 ــ د.

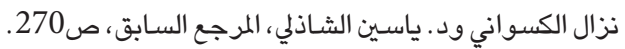

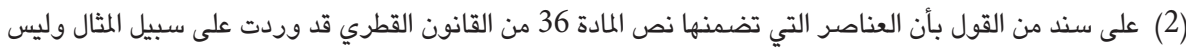

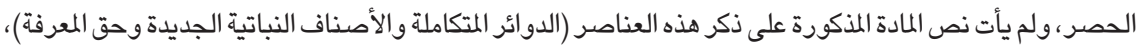

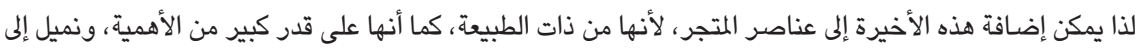

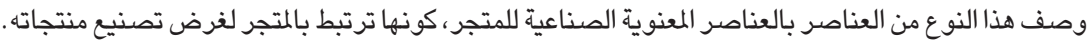
(3) المادة 2 من القانون رقم 30 لسنة 2006 بشأن براءات الاختراع المناع القطري.

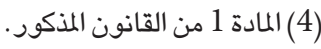

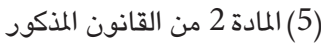




$$
5 \text { - } 4 \text { - ألا يكون الاختراع متعارضًاً مع أحكام الشريعة الإسـلامية. }
$$

ويظهر الاختراع -في الأعم الأغلب- إلى حيز الوجود، بإحدى الصور الآتية(1): الأولى:

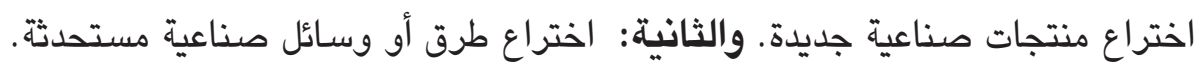
والثالثة: اختراع تطبيق جديد لطرق أو وسائل صناعية معروفة . والرابعة : اختراع التراكيب.

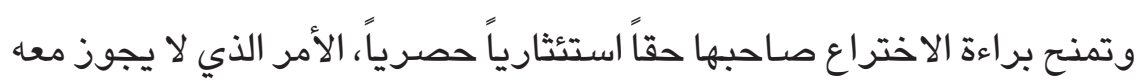

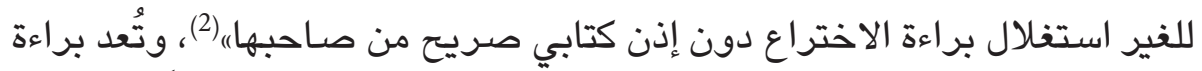

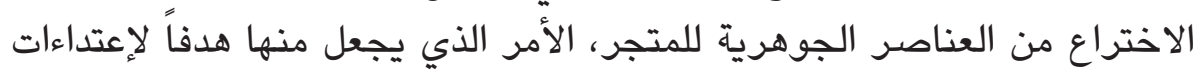
الغير ، والتي قد تأخذ أحد الأفعال الآتية(3): 1 - تقديم مستندات أو الإدلاء بمعلومات غير صحيحة أو مزورة للحصول على براءة اختراع.

$$
2 \text { - } 2 \text { - تقليد الاختراع موضوع البراءة. }
$$

4 - الزعم بامتلاك براءة اختراع أو وضـع بيانات مخالفة للحقيقة على المنتجات. 5 - التعدي - عمداً- على أي حق يحميه قانون البراءات.

ويتمتع صاحب براءة الاختراع بالحماية القانونية الإجرايئة أو المدنية أو الجزائية أو الدولية إذا توفرت الشروط اللازمة لذلك(4)، وفي سبيل توفير حماية قانونية مبكرة

$$
\text { (2) (1) المادة } 2 \text { من القانون المذكور . } 2 \text { من القانون المذكور. }
$$

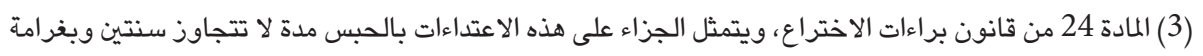

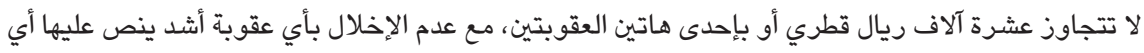

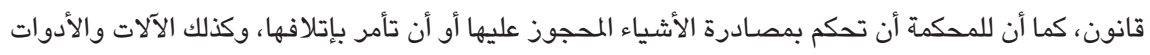

$$
\text { التي استعملت في التزوير. }
$$

(4) انظر : المواد و 21 و22 و24 من قانون براءات الاختراع القطري. 
لبراءة الاختراع يعطي القانون لصاحبها الحق في أن يطلب من المحكمة المختصـة(1)

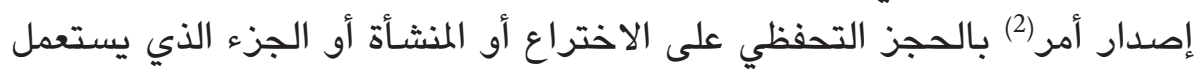

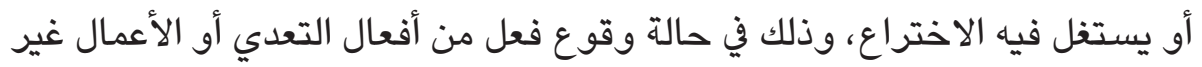

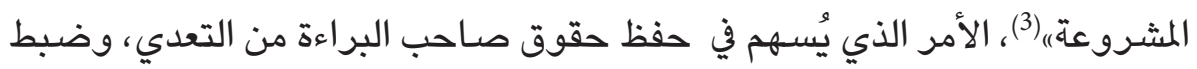

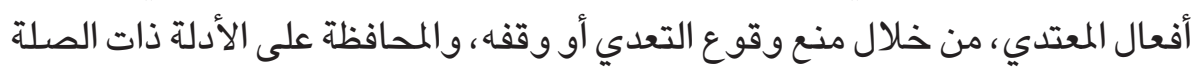

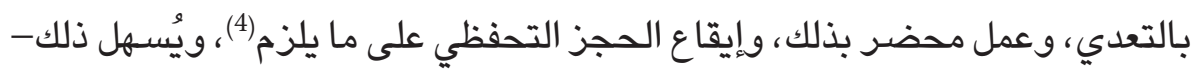

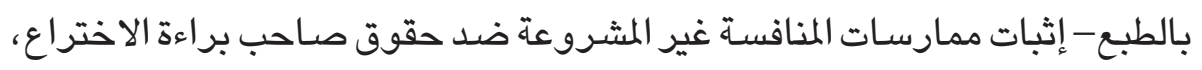

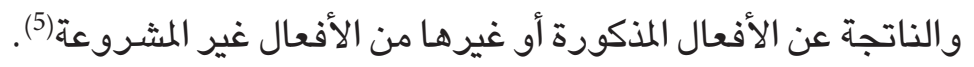

وللمحافظة على آثار الإجراءات المذكورة حال الأمر بها من المحكمة المختصـة،

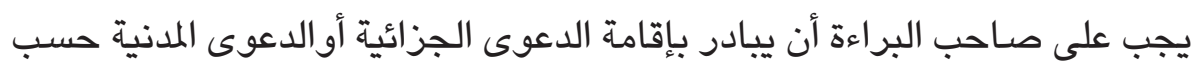

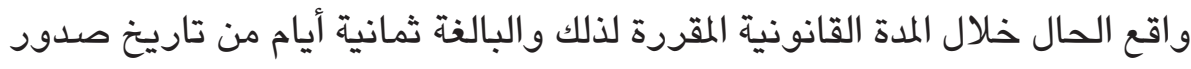

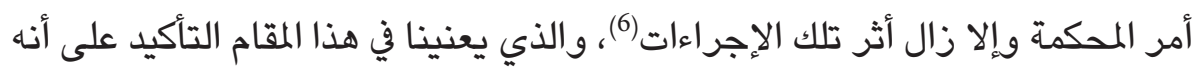

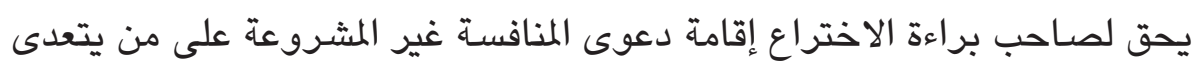

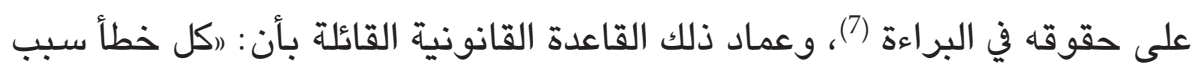
ضرراً للغير يلزم من ارتكبه بالتعويضه" (8).

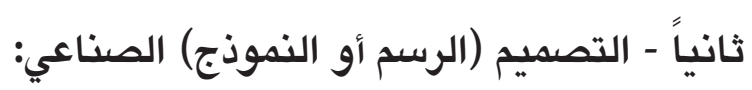

حدد المشرع القطري الأحكام القانونية للرسوم والنماذج الصناعية، في المواد 42 المناء

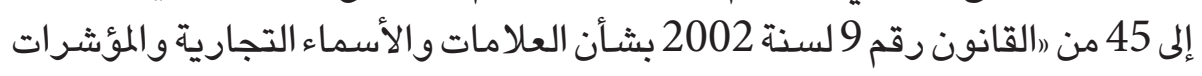
(1) تحدد (المحكمة المختصةة) في هذا الصدد وفقا لأحكام القواعد العامة في الاختصاص القضائي سندا للمادة 22 و24 المات

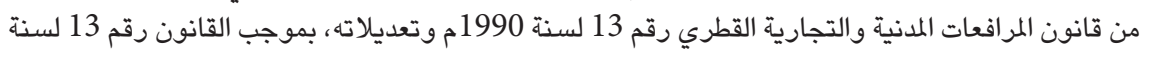

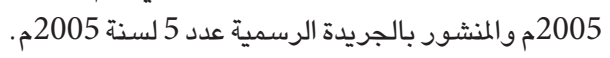

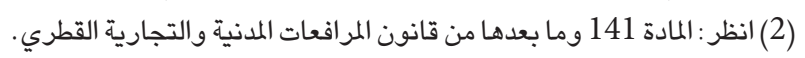
(3) (3) المادة 24 من قانون براءات الاختراع القطري.

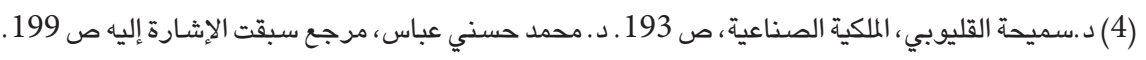

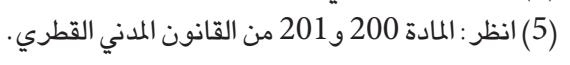
(6) المادة 22 من قانون براءات الاختراع القطري.

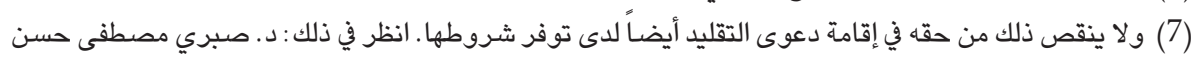

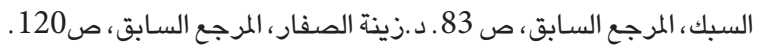
(8) (8) انظر : المادة 199 من القانون المدني القطري. 


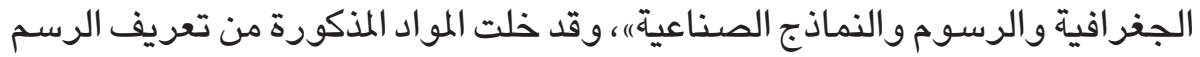

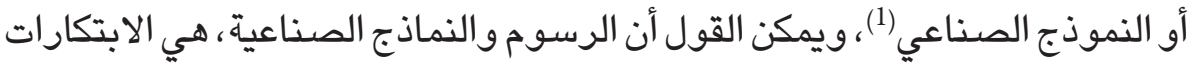

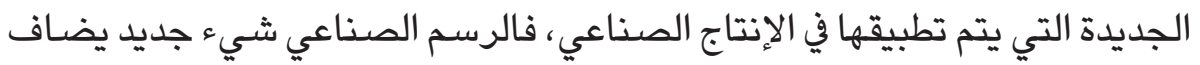

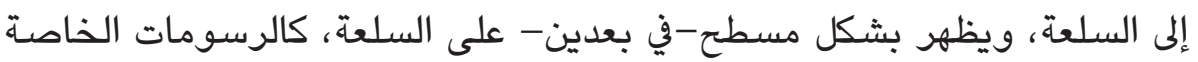

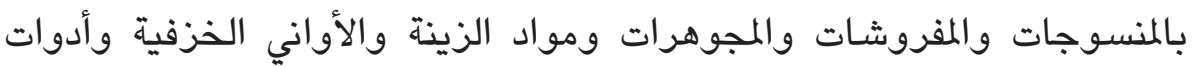

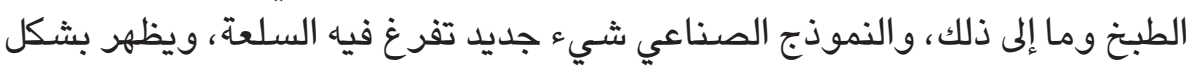

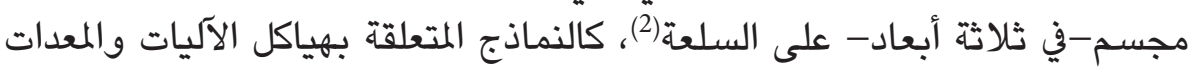

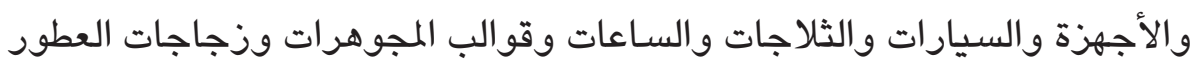

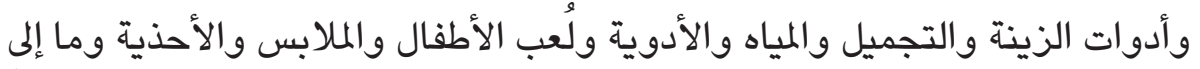

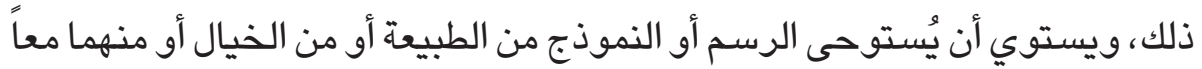

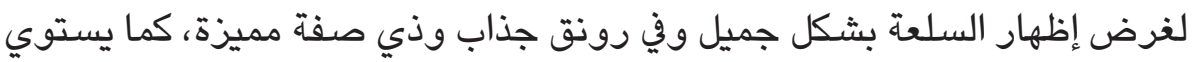

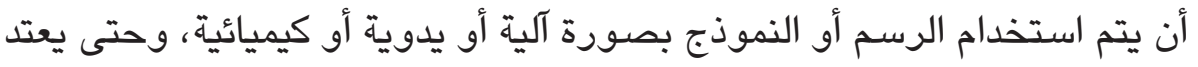

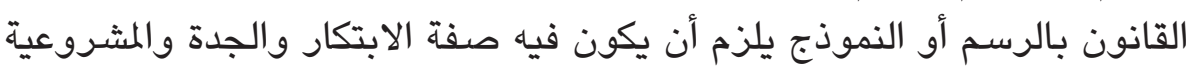

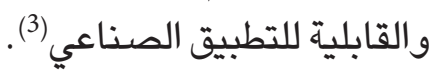

وتظهر أهمية التصاميم الصناعية في جوانب عديدة من أبرزها: جانب الإنتاج

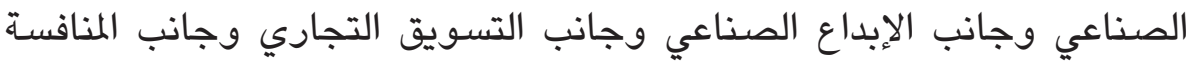

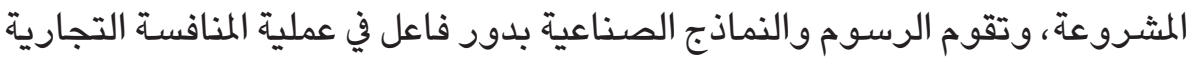

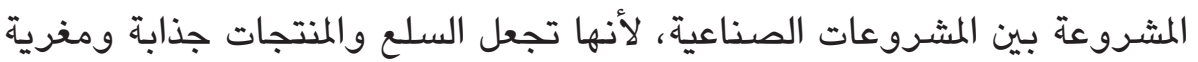

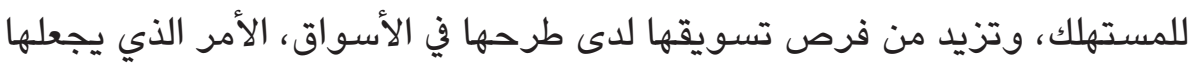

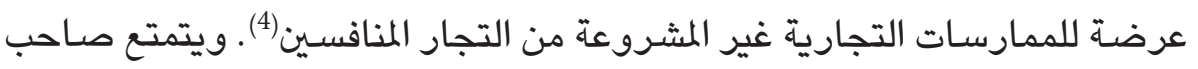

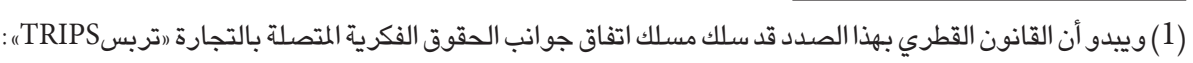

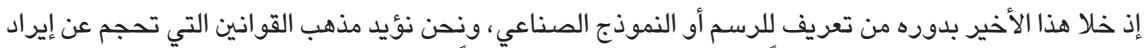

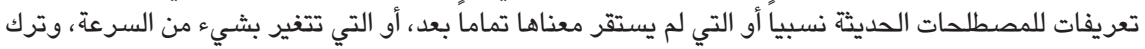

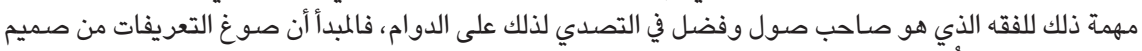

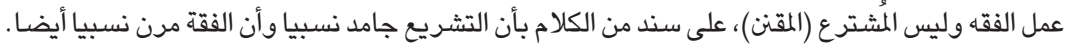

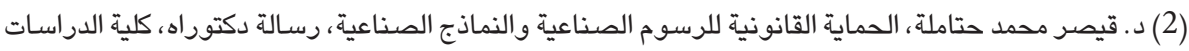

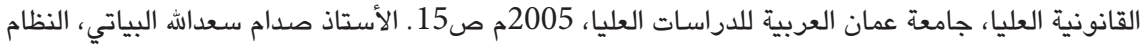

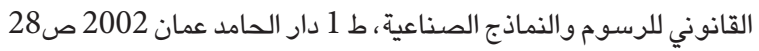
(3) (3) المادة 42 من القانون المذكور. (4) د. صلاح زين الدين، الحماية القانونية للرسوم والنماذج الصناعية في القانون القطري، المجلة القانونية والقضائية،

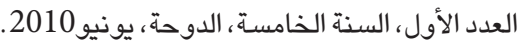


الرسم أو النموذج الصناعي بحق الاستئثار به، الأمر الذي يقتضي حق حمايته من أي القي

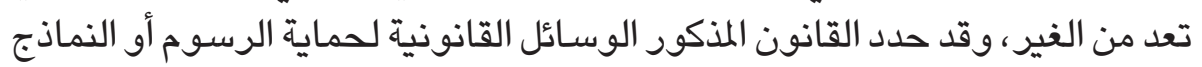

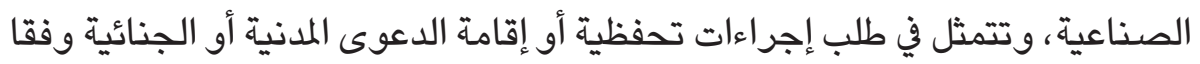

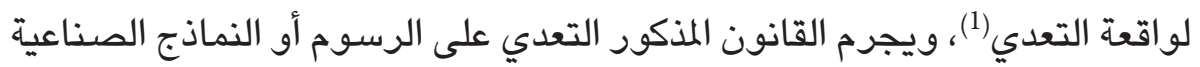

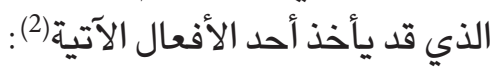

$$
1 \text { - تقليد أو تزوير الرسم أو النموذج الصناعي. }
$$

2 - استعمال الرسم أو النموذج الصناعي المقلد أو المزور.

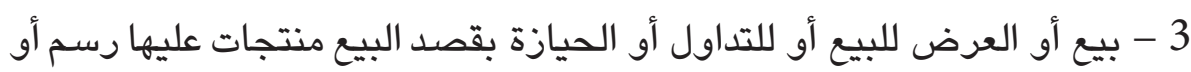
نموذج صناعي مزور أو مقلد.

4 - تقديم أو عرض خدمات مستغلاً -بغير حق- رسم أو نموذج صناعي. 5 - وضـع بيانات -بغير حق- على المنتجات أو الخدمات أو الأوراق التجارية أو غيرها تؤدى إلى الاعتقاد بتسبـيل رسم أو نموذج صنات صناعي.

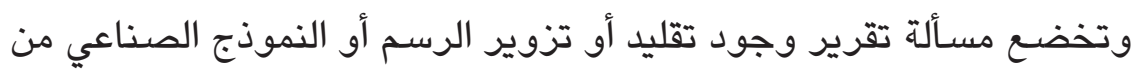

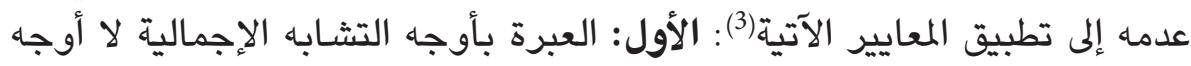

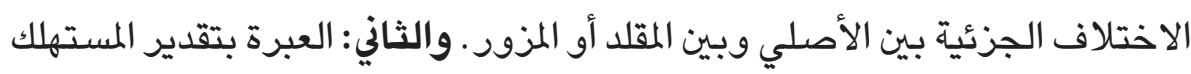

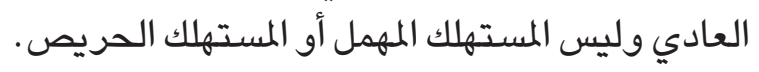

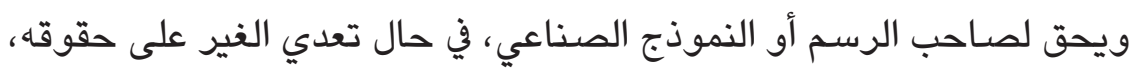

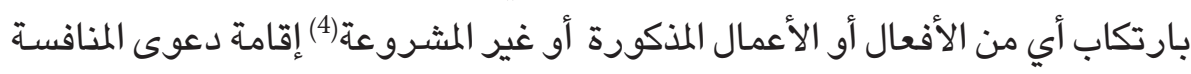

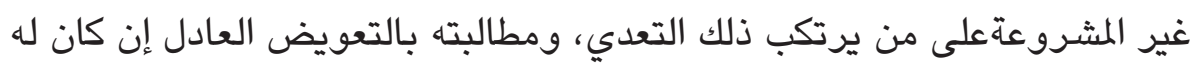

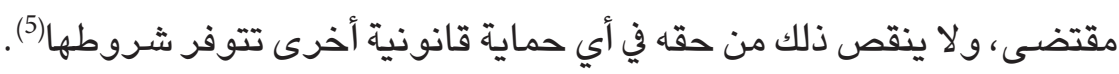
(1) (1) (المادة 46 و 47 من القانون المذكور.

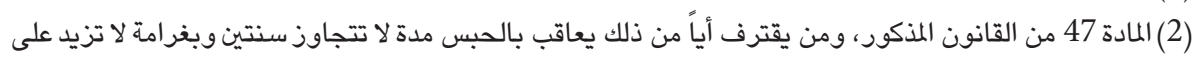

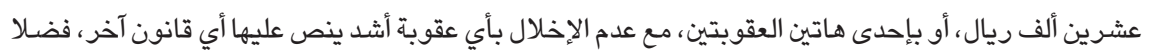

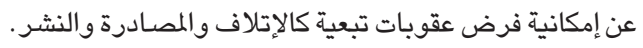

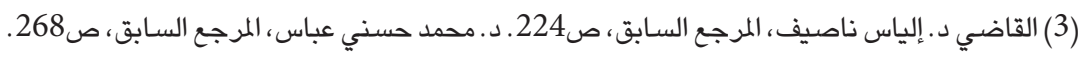

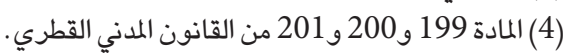

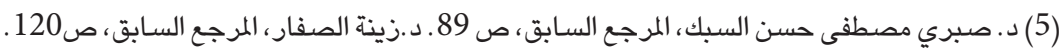




\section{ثالثاً - تصميم الدوائر المتكاملة:}

يعرف القانون القطري الدوائر المتكاملة بأنها: (رمنتج يؤدي وظيفة إلكترونية

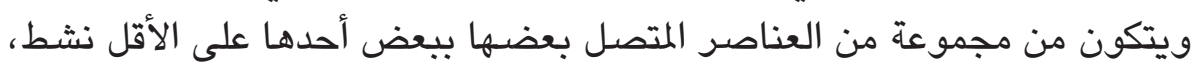

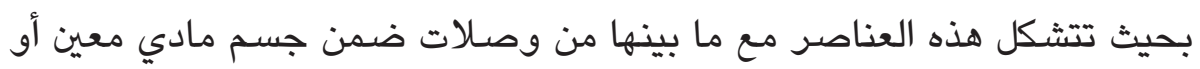

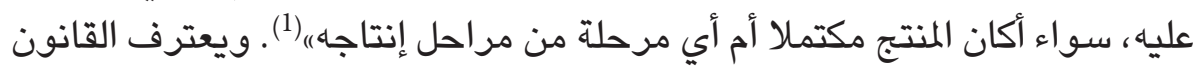

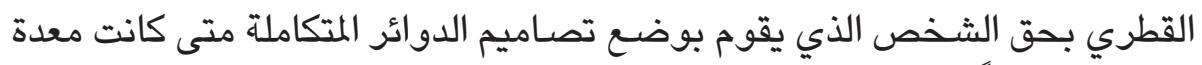

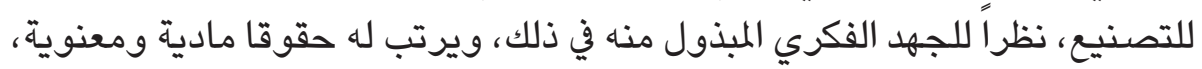

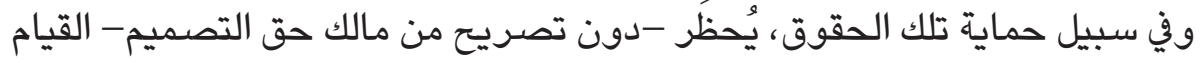

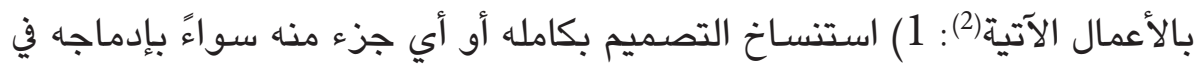

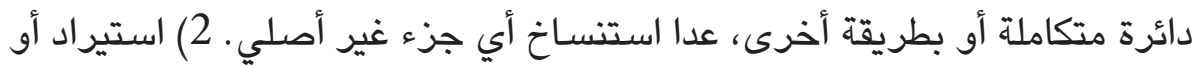

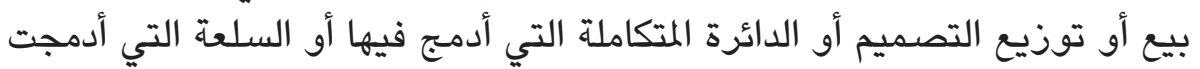

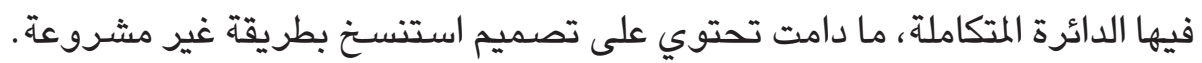

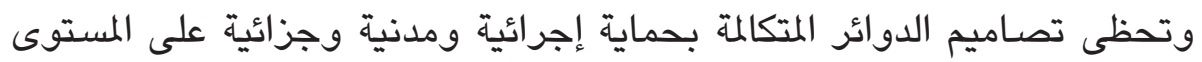

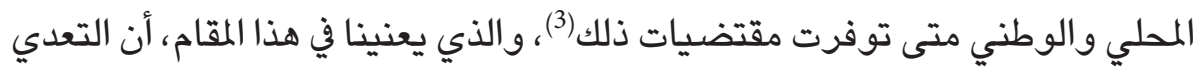

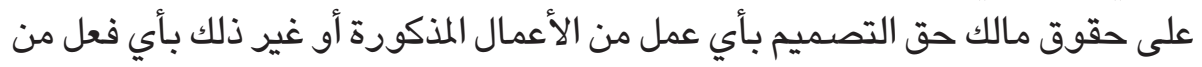

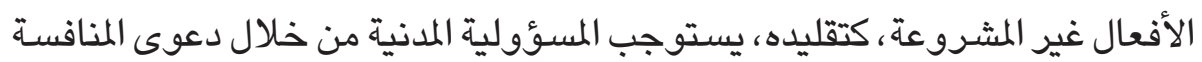

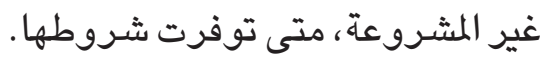

\section{رابعاً - الأصناف النباتية الجديدة:}

يقصد بالأصناف النباتية الجديدة، أي صنف نباتي مستنبط، يتصف بالجدة

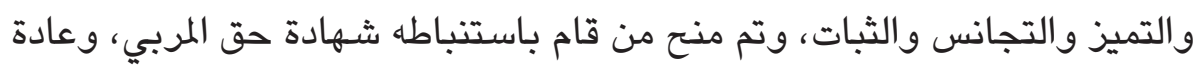

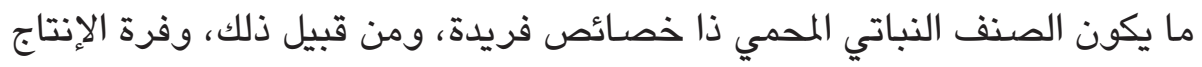

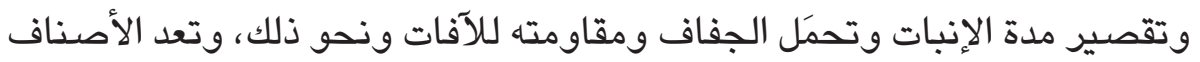

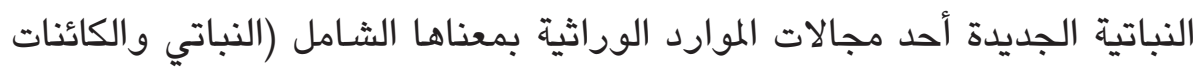

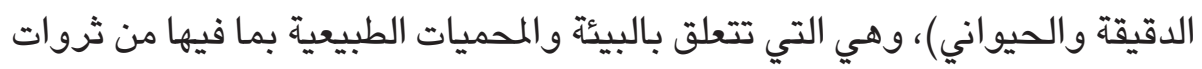
مراعي وغابات ونباتات أخرى ذات أهمية زراعية وغذاء ولية وموارية واردية حيوانية نادرة. (1) المادة 1 من القانون رقم 6 لسنة 2005 بشأن حماية تصاميم الدوائر المتكاملة القطري.

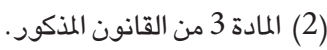
(3) د. سميحة القليوبي، الملكية الفكرية، الطبعة الرابعة، ، دار النهضة العربية، ، القاهرة 2003، صاند370. 
ولم تلق هذه الموارد الاهتمام التشريعي المناسب بعد في الدول العربية، الأمر الذي

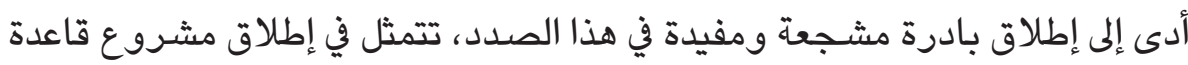

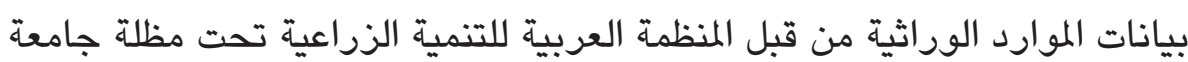

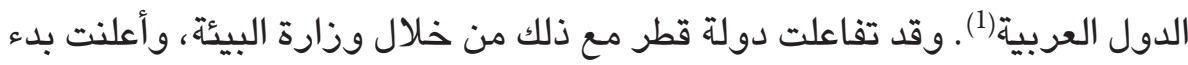

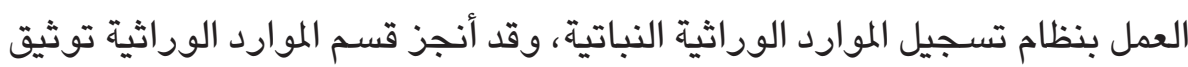

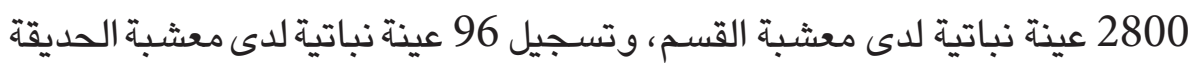
الملكية البريطانية، وهناك سعي حثيث إلى جعل قاعدة بيانات الموارد الوراثية كنزًا

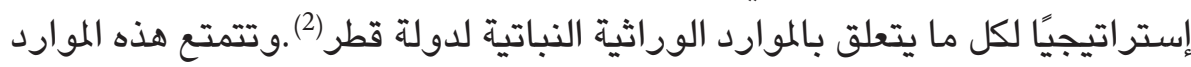

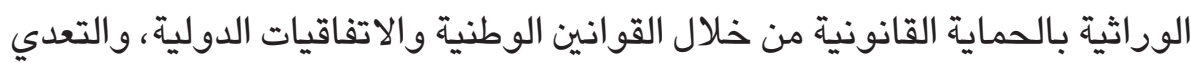

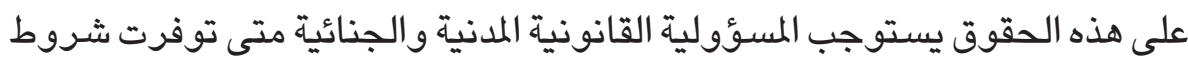

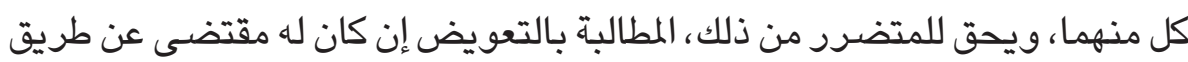

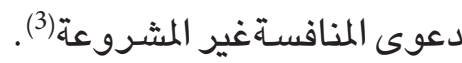

\section{خامساً - حق المعرفة:}

ينصرف هذا الحق إلى المعرفة الفنية التي تتمثل في وسيلة أو طريقة صناعية ذات طبيعة سرية، وتتضمن مجموعة من المعلومات أو التجارب الفنية تمكن من توفير وفي وليه

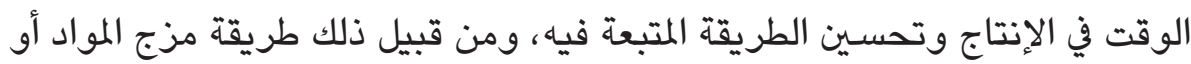

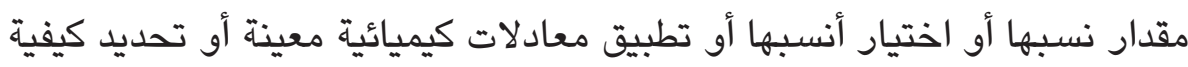

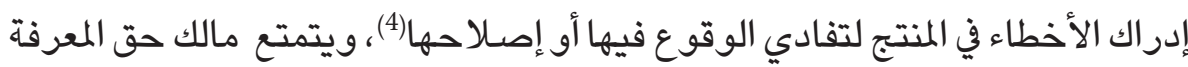

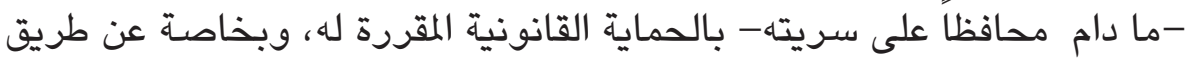

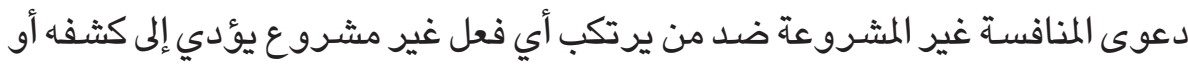
إفشائه أو غصبه أو نحو ذلك فئ.

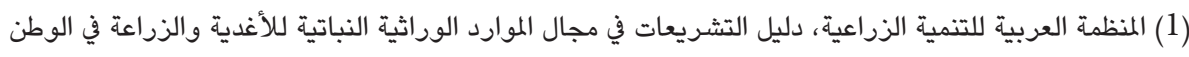

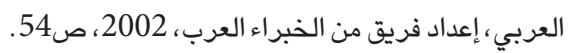

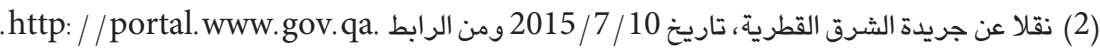

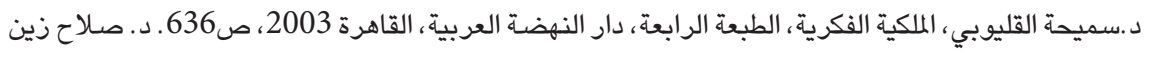

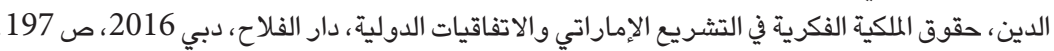

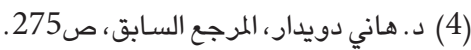
(5) المادة 39 من اتفاق تربس. دو دار، المرع. 


\section{الغصن الثالث}

\section{أعمال المنافسة غير المشروعة التي تتضمن \\ اعتداءً على العناصر المعنوية الفكرية}

تتمثل العناصر المعنوية الفكرية للمتجر في حقوق المؤلف والحقوق المجاورة له(1)،

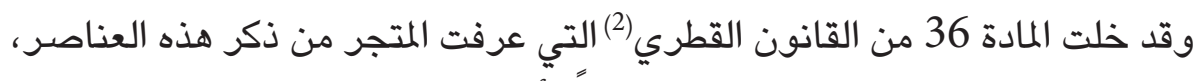

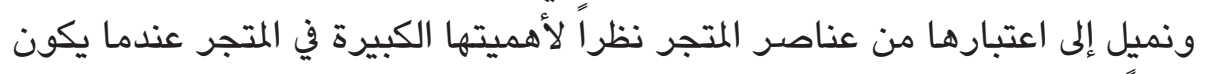
قائماً لاستغلال هذه الحقوق(3)، ومنها برامج الحاسب الآلي ودور النشر والمسـارح

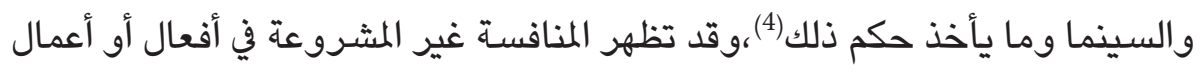

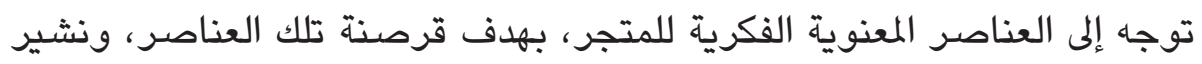

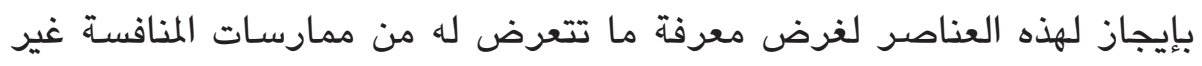

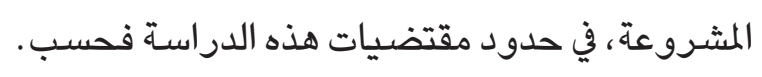

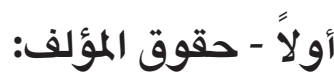

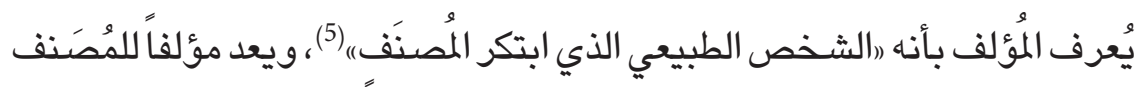

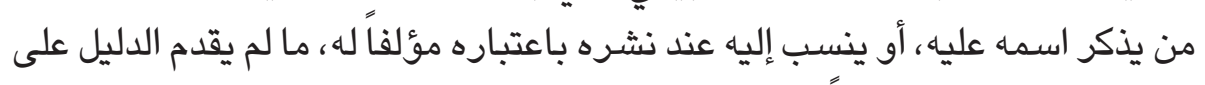

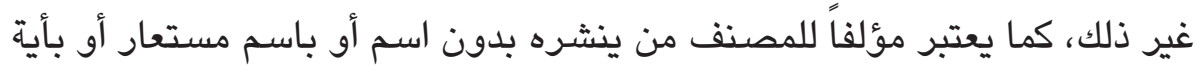

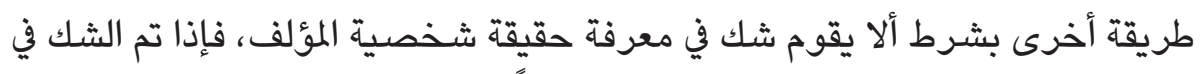

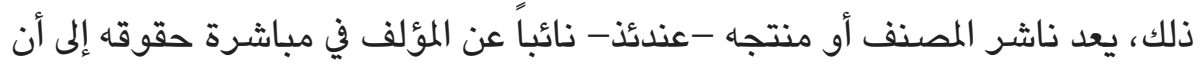

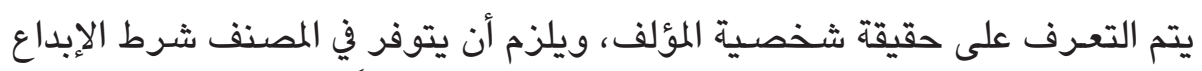

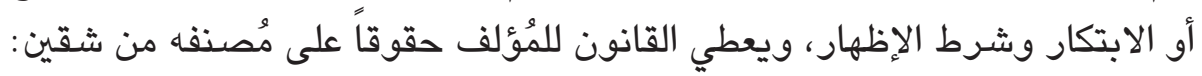

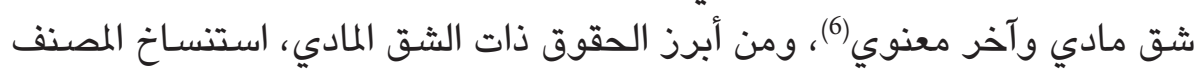

$$
\begin{aligned}
& \text { (1) ينظم هذه الحقوق، قانون حماية حق المؤلف والحقوق المجاورة القطري رقم } 7 \text { لسنة 2002ذ. } \\
& \text { (2) سبقت الإشـارة إلى هذه المادة في أكثر من موقع المؤه }
\end{aligned}
$$

(3) Dr. Mohamed Salem Abou El Farag, ibid, 2009. p. 253.

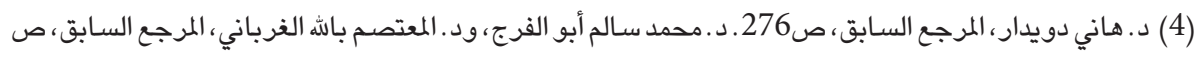

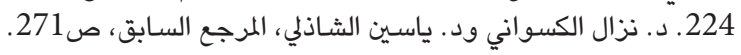

(5) (5) المادة 1 من القانون المذكور .

(6) محكمة التمييز القطرية الطعن رقم 58 لسنة 2012 تاريخ 22 / 2012 / 2012، والطعن رقم 225 لسنة 2011 تاريخ $2012 / 3 / 13$ 
وترجمته وتعديله وتوزيعه وتأجيره وأداؤه ونقله(1)، وأما الحقوق ذات الشق المعنوي

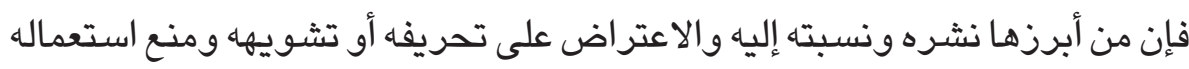

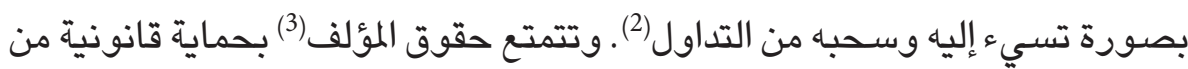

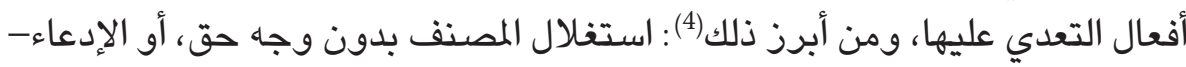

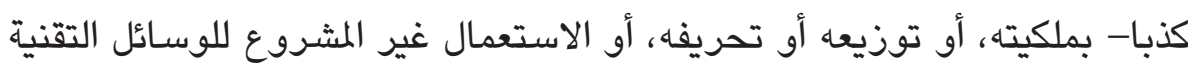

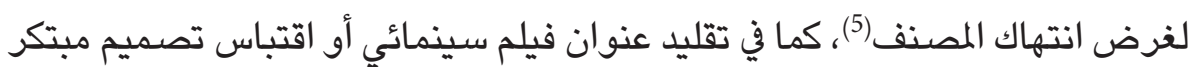

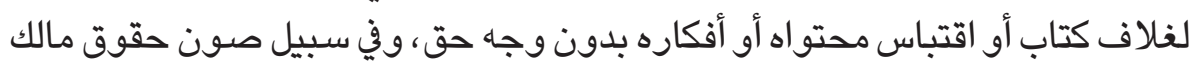

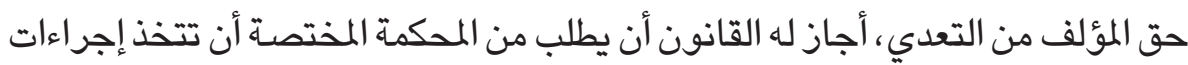

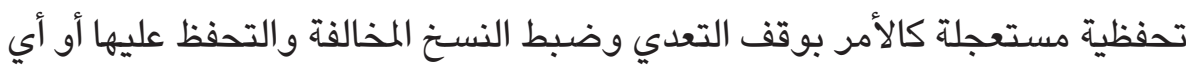

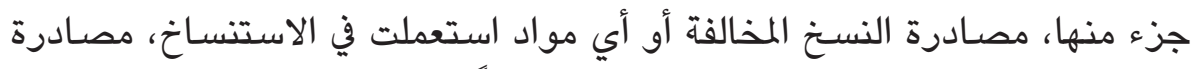

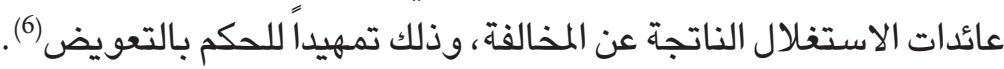
وعليه فإن التعدي على حقوق المؤلف بأي فعل من الأفعال المذكورة أو أي أفعال

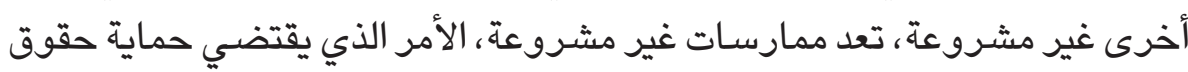

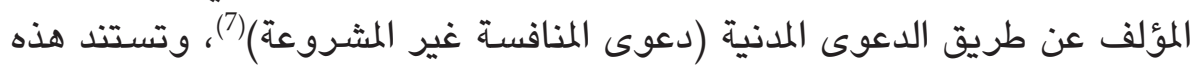

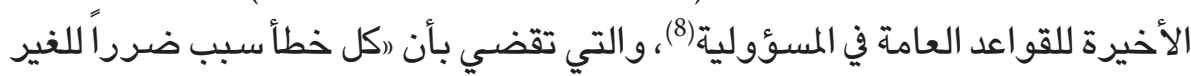

$$
\begin{aligned}
& \text { (1) المادة } 7 \text { من القانون المذكور. }
\end{aligned}
$$

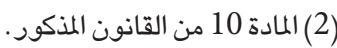

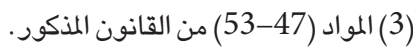

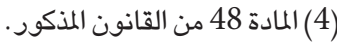

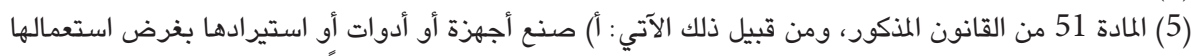

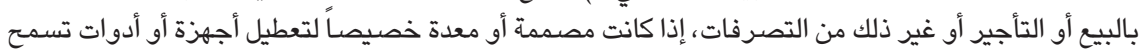

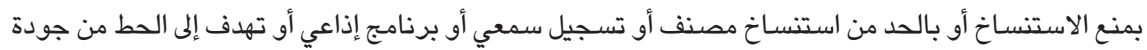

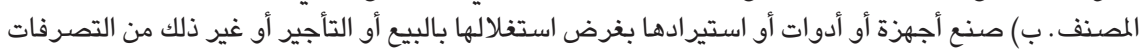

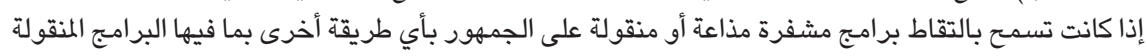

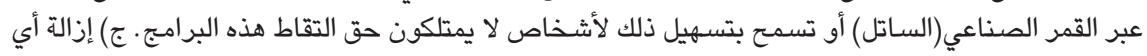

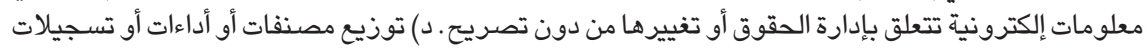

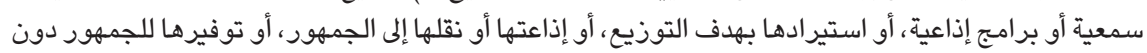

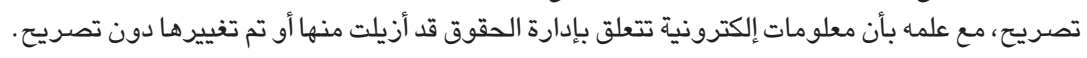

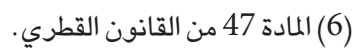
(7) د. عبدالرشيد مأمون ود. محمدعبدالصادق، حقوق المؤلف والحقوق المجاورة، دار النهضة العربية، القاهرة

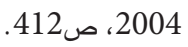
(8) د. جمال عبدالرحمن محمد علي ود . عادل أبو هشيمة محمود حوته، الملرجع السابق ، ص210. 
يلزم من ارتكبه بالتعويض)(1)، وهو ما يستلزم وجود شروط ثلاثة هي : الخطأ،

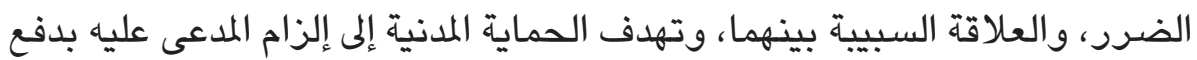

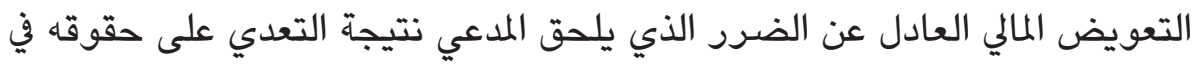

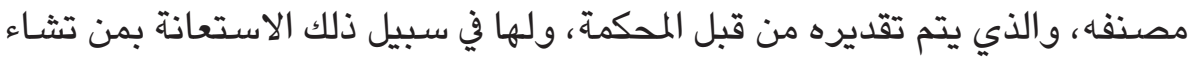

$$
\text { ثنانياً - الخبراء في هذا الصدد(2). }
$$

ينظم القانون القطري الحقوق المجاورة في المواد من 40 إلى 43 منها، وقد حددت هذه المواد ما يتعلق بالحقوق المجاورة من أحكام، ويقصد بذلك الحقوق التي يمنحها القانون

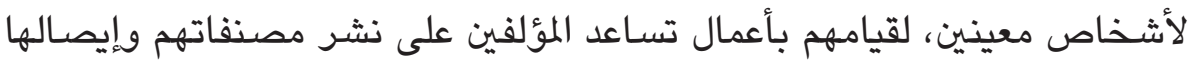

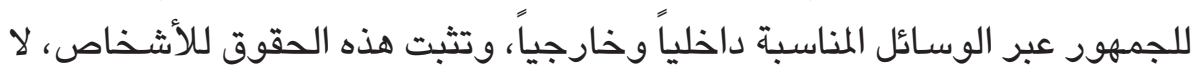

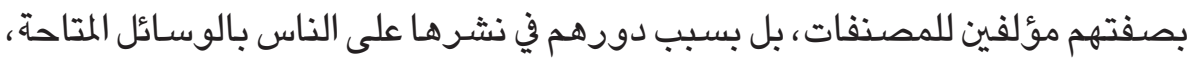

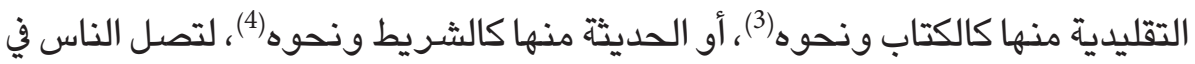

$$
\text { مواقعهم في أرجاء المعمورة، وأصـاب الحقوق المجاورة هـ (5): }
$$

1 - فنانو الأداء: وهم "المغنون والموسيقيون وكل من يغني أو يلقي أو يتلو أو

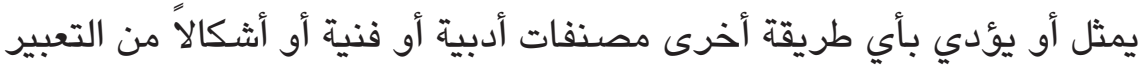

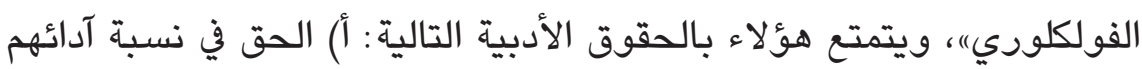

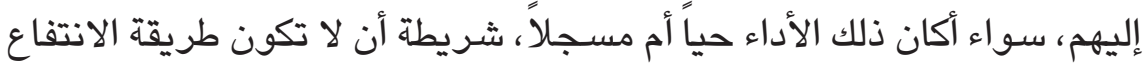

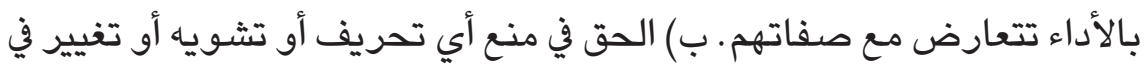

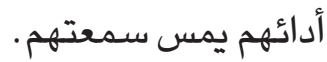

$$
\text { (1) (1) المادة } 199 \text { من القانون المدني القطري. }
$$

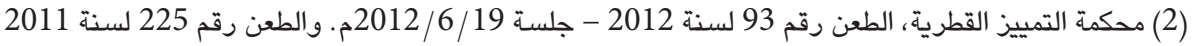
تمييز جلسة 13 /3/ 3 / 2012م.

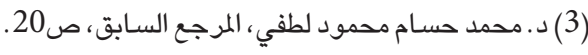

(4) المحامية جيهان حسين فقية، حماية الملكية الفكرية عبر الأقمار الصناعية، المنشورات الحقوقية (صادر)، بيروت 2006، ص40 مان. (5) مادة 1 من القانون المذكور . 
2 - منتجو التسجيلات السمعية: وهو (الشخص الطبيعي أو المعنوي الذي يتخذ

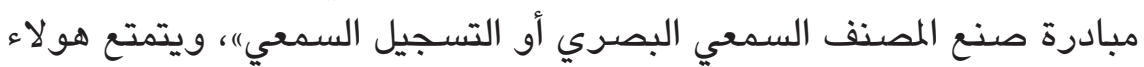

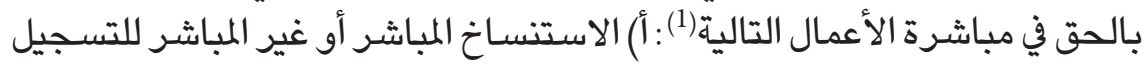

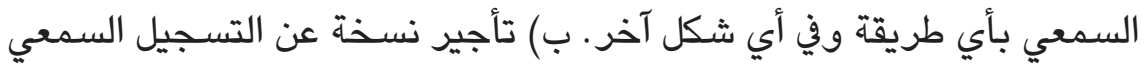

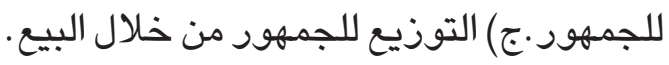

3 - هيئات الإذاعة: وهي التي تقوم بعملية انقل المصنف أو الأداء أو التسجيل

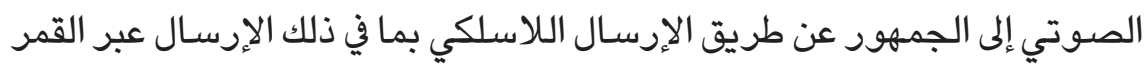

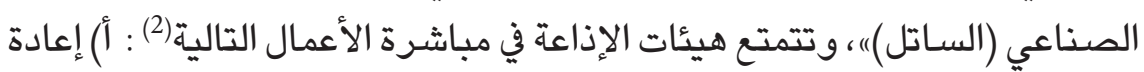

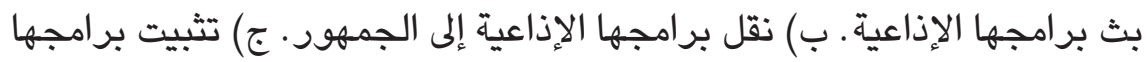
الإذاعية . د) استنساخ تثبيت لبرامجها الإذاعية.

وتحظى حقوق أصحاب الحقوق المجاورة بذات الحماية الإجرائية والحماية

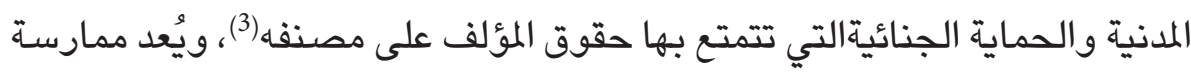

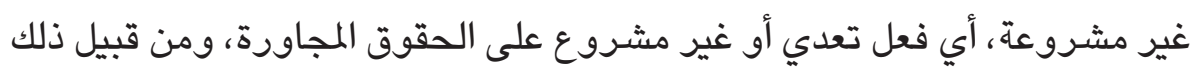

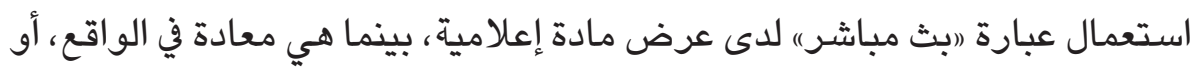

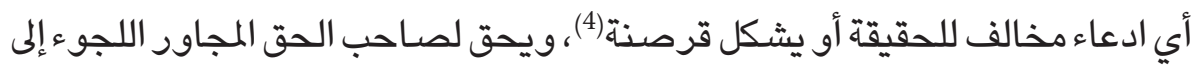

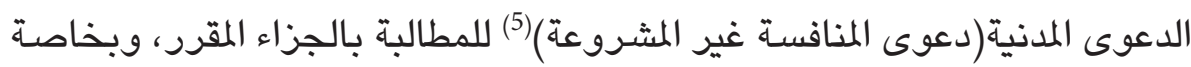

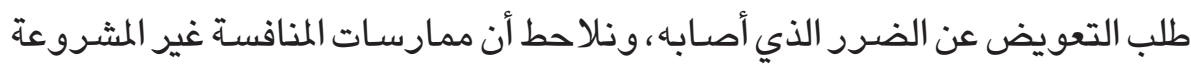

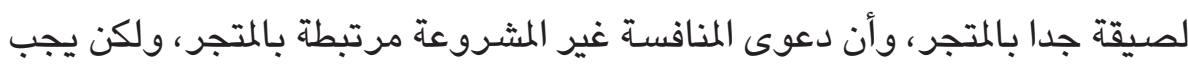

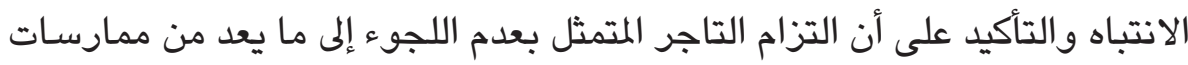

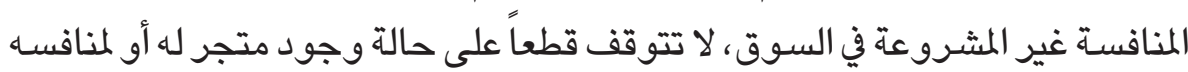
فحسب، بل يبقى هذا الالتزام قائماً في عنق التاجر في الحالتين : حالة وجود المتجر أو الم

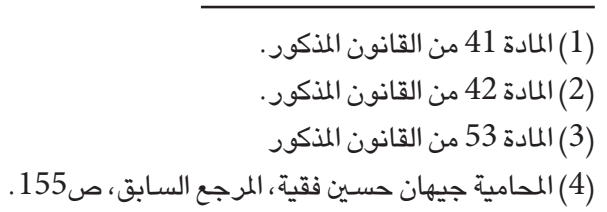

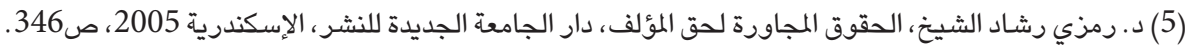

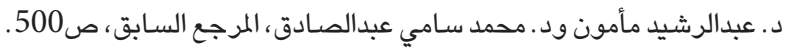


عدم وجود المتجر (1) على سند من القول بأن الالتزام بالمنافسـة المشروعة والامتناع عن المنافسـة غير المشروعة التزام مهني تجاري يترتب على التاجر (الطبيعي أو المعنوي)

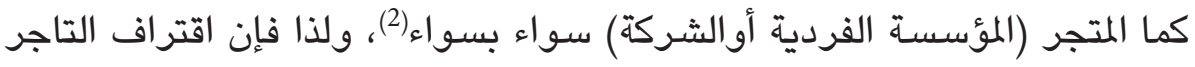

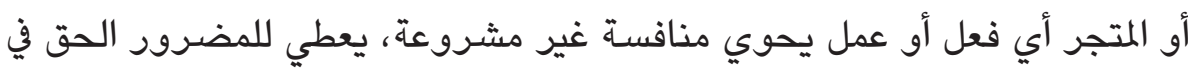

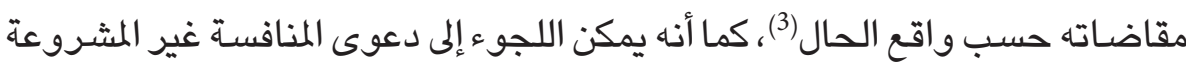
- لدى توفر شرائطها- ضـ التاجر الذي يقترف ممارسة غير مشروعة سواء كان يملك متجراً أم لا يملك، كما سنرى ذلك في في المبحث الثالث من هذه الدراسة.

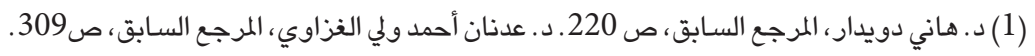

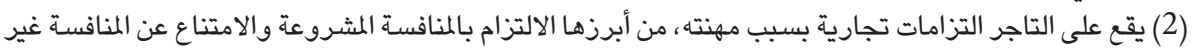

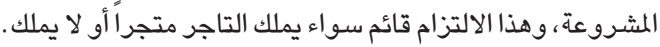
(3) د. عمر محمود حسن، المحل التجاري في الفقة الإسلامي، منشورات الحست الحلبي الحقوقية، الطبعة الأولى، بيروت 2015، 


\section{المحث الثالث}

\section{دعوى المنافسة غير المثنروعة}

تُسـهم دعوى المنافسـة غير المشـروعة في المحافظة على مصداقية النشـاط التجاري على وجه الخصوص باعتباره رافعة مهمة من رافعات النشـاط الاقتصـادي على وجه العموم، وتهدف إلى ضبط النشاط التجاري في حدود ما تقتضيه مبادى الأخلاق من

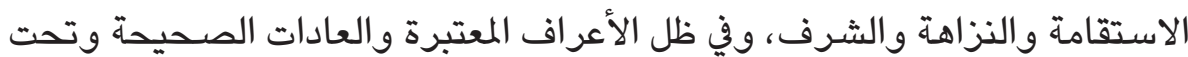

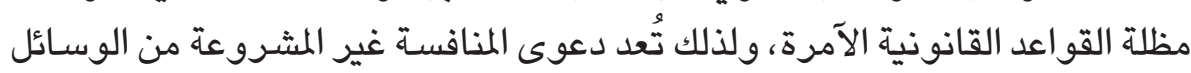

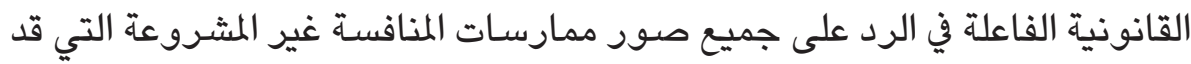
تقع من بعض التجار خلال ممارسـة نشـاطهم التجاري، وتحقق الحماية القانونية اللازمة للمتضررين من الممارسـات المنافسـة غير المشروعة، سواء أكانوا من التجار

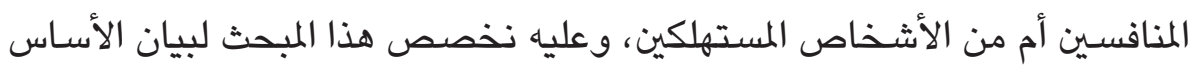
القانوني لدعوى المنافسـة غير المشروعة وشـروط إقامتها والجزاء الذي يترتب على نجاحها، وذلك في ثلاثتة مطالب على التوالي.

\section{المطلب الأول}

\section{الأساس القانوني لدعوى المنافسة غير المثنروعة}

يبدو أن الفقه لم يجمع علىقول واحد في تحديد الأسـاس القانوني لدعوى المنافسـةغير المشـروعة، إذ نجد أكثر من رأي قد قيل في ذلك، ويمكن رد الآراء التي قيلت في هذا الصدد إلى الآتي (1):

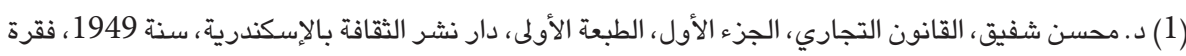

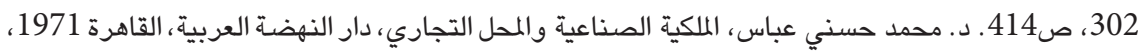

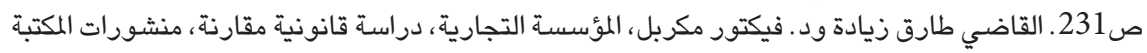

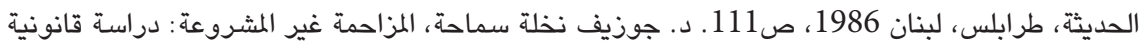

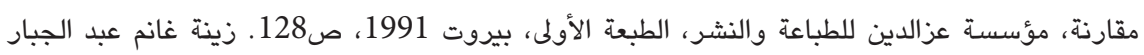

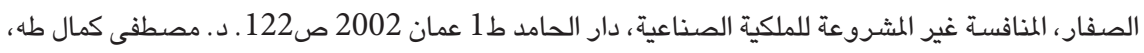

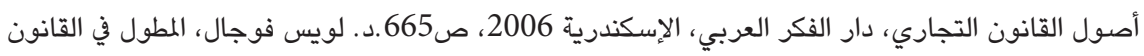

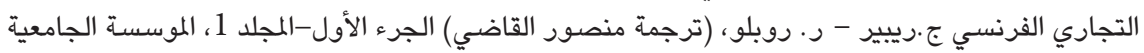

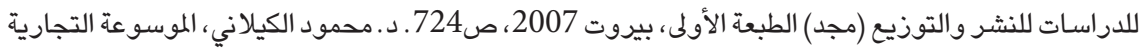

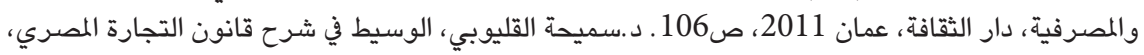

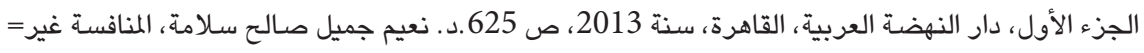




\section{الرأي الأول - يرى أن دعوى المنافسة غير المشروعة تستند إلى القواعد العامة}

\section{في المسؤولية التقصيرية:}

يقوم هذا الرأي على حجة وجيهة تتمثل في أن القواعد القانونية العامة واجبة

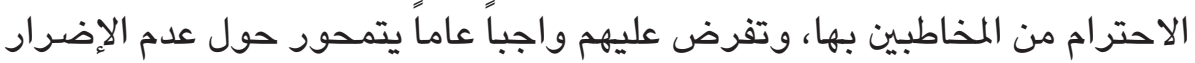

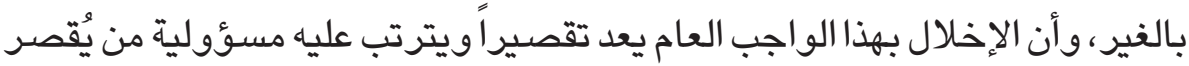

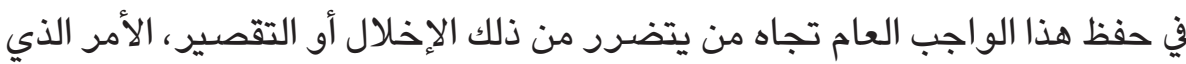
يقتضي وجود ثلاثة شروط في آن هي: الخطأ والضرر والرابطة السبيية بينهما،

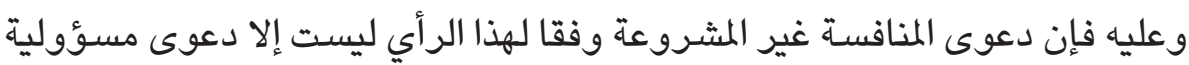

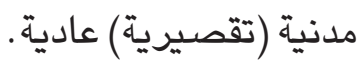

وإذا كان يوجد لهذا الرأي تأييد كبير من الفقه والقانون والقضـاء منذ زمن بعيد(1)،

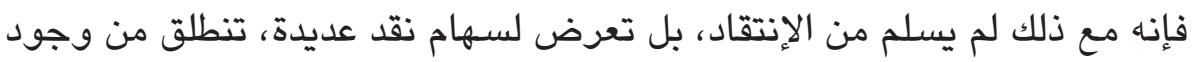

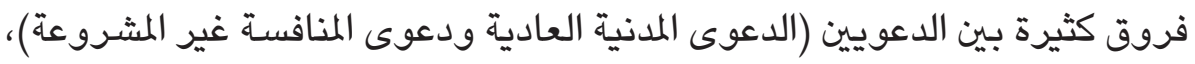
ومن قبيل ذلك:

1 - تقف الدعوى المدنية عند حد عدم إلحاق الضرر بالغير فحسب، سواء أكان سبب

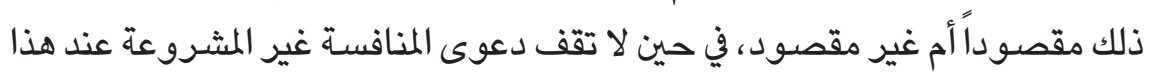

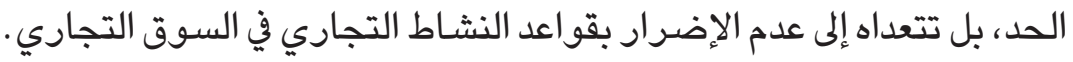
2 - تستلزم الدعوى المدنية وجود الشروط الثلاثة، الخطأوالضرر والعلاقة السبيية

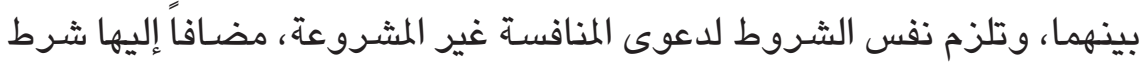
آخر أيضـاً وهو ذلك الذي يقتضي وجن لفود حالة منافسة.

3 - تقتضى الدعوى المدنية وقوع أو وجود ضرر بالفعل، في حين يكفي لقيام دعوى

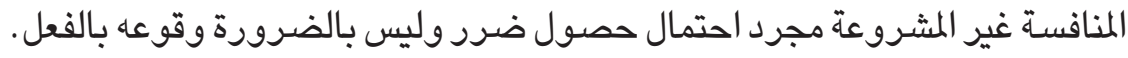

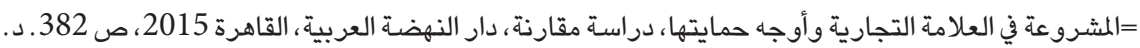

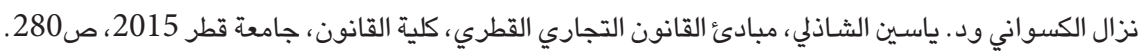

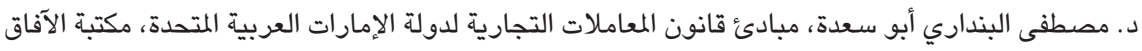

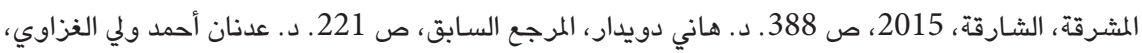

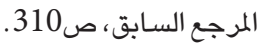
(1) د. لويس فوجال، المرجع السابق، ص724. 724 ـ ـ جوزيف نخلة سماحة، المرجع السابق، ص128. 
4 - تهدف الدعوى المدنية إلى تعويض المتضرر فحسب، في حين أن دعوى المنافسة غير المشروعة تهدف -إضـافة إلى جبر الضرر - وقف التعدي ومنع الاستمرار فيه أيضًاً. 5 - تحمي الدعوى المدنية مصلحة المتضرر فحسب، في حين أن دعوى المنافسة غير

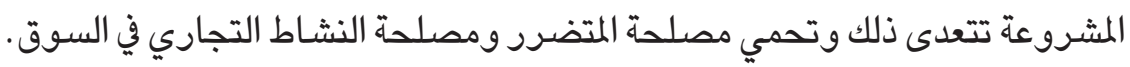
ويلاحظ أن هذه الانتقادات تدور حول الهدف من الدعويين ونطاق الحماية التي توفره كل منهما، الأمر الذي يمكن معه القول بأن الدعوى المدنية أقرب إلى الدعوى

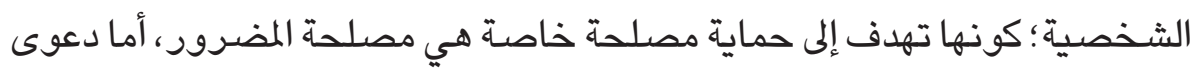

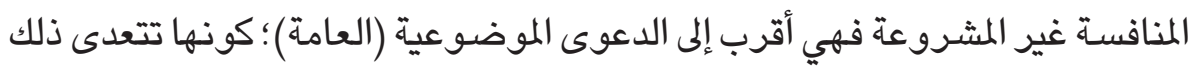

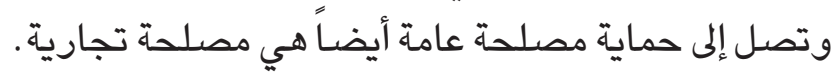

الرأي الثاني- يرى أن دعوى المنافسة غير المشروعة تستند الى التعسف في

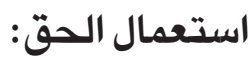

يقوم هذا الرأي على حجة منطقية مفادها أن المنافسة حق للتاجر ما دامت ممارسـاته

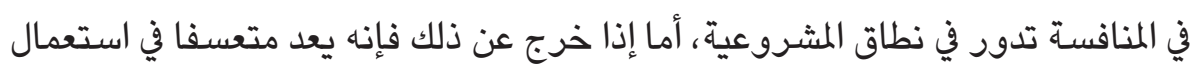

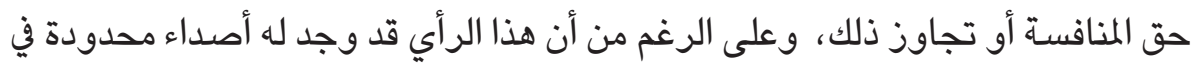

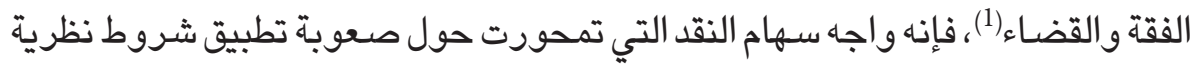

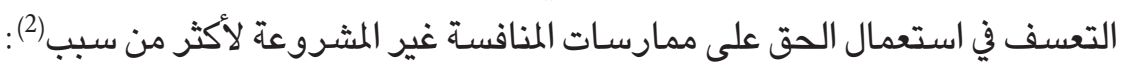
1 - يتجاوز المتعسف في استعمال الحق، الغاية التي وجد من أجلها الحق ذاته، في

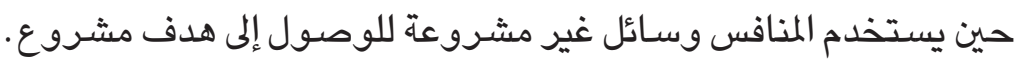
2 - يصاحب التعسف باستعمال الحقٍ سوء نيه لدى المتعسف، في حين ليس بالضرورة

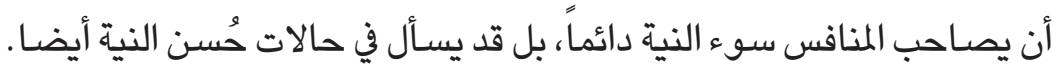
3 - ليس من المنطق قياس الضرر الناتج عن التعسف في استعمال الحق على الضرر الناتج

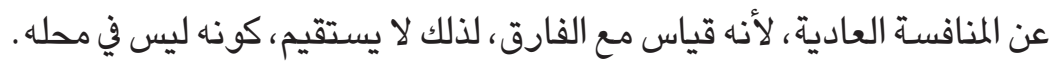
ويلاحظ أن هذه الانتقادات تنصب على نفي المكانية الجمع بين شروط التعسف

$$
\text { (2) د. د. جوزيف نغلة سماحة، المرجع السابق، ص129. } 129 .
$$




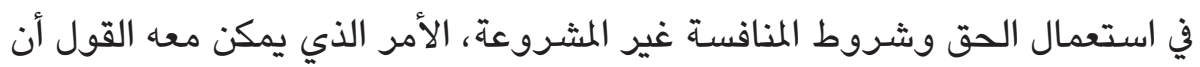

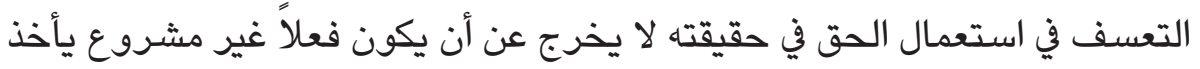

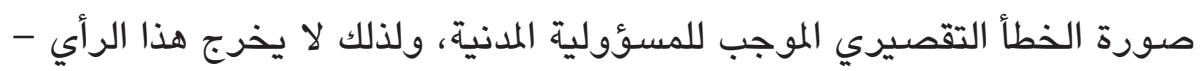

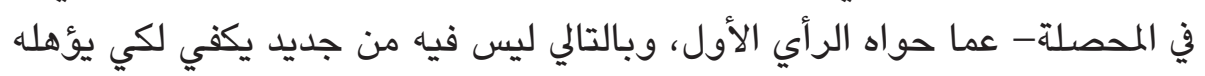

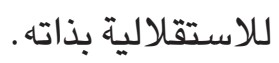

الرأي الثالث - يرى أن دعوى المنافسة غير المشروعة تستند إلى حق التاجر

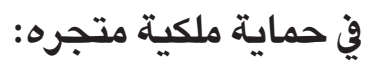

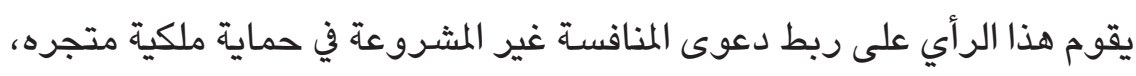

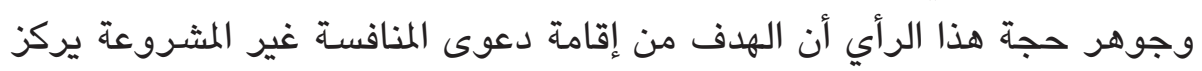

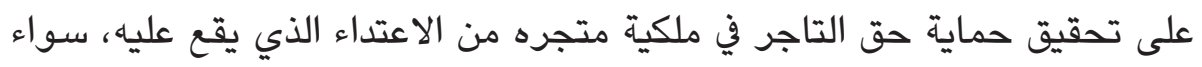

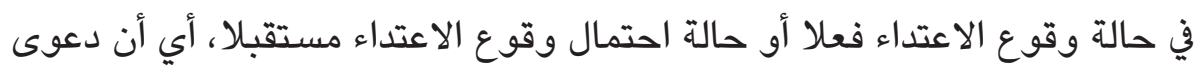

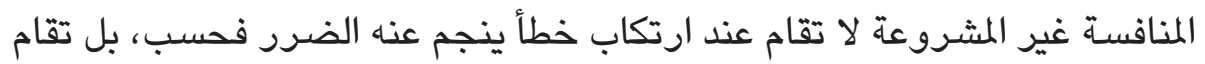

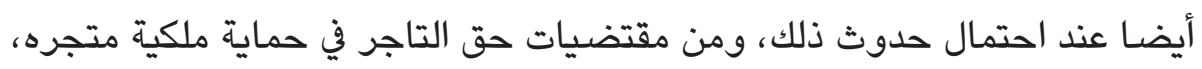

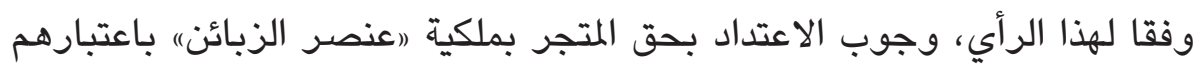

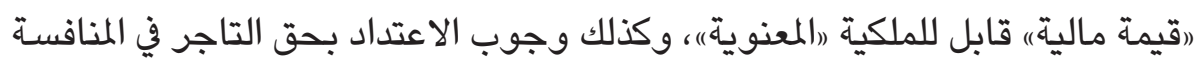
الشريفةوالنزيهة (1).

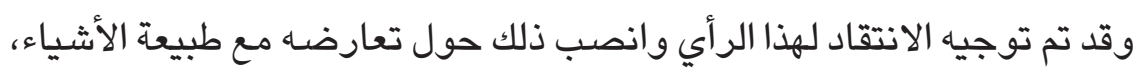

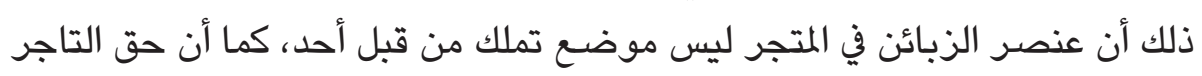

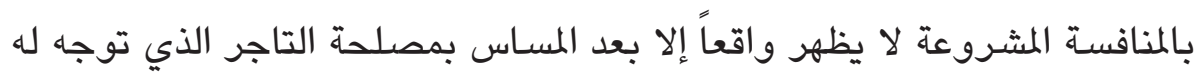

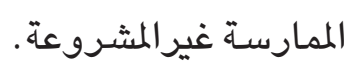

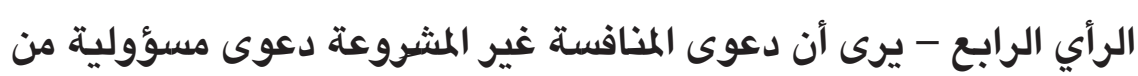

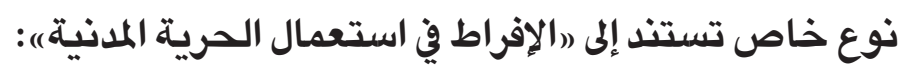

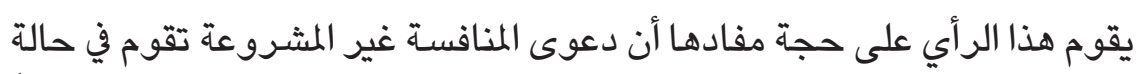

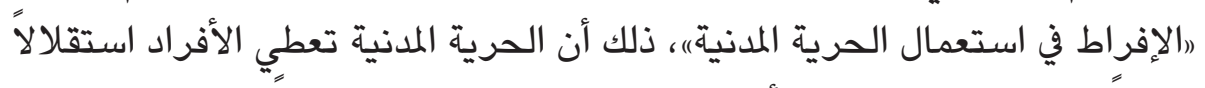

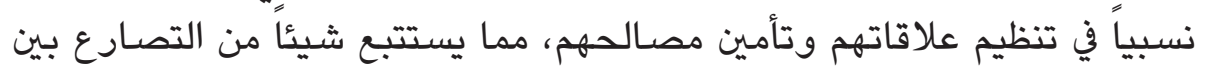
(1) القاضي طارق زيادة ود . فيكتور مكربل، المرجع السابق، ص111 
المتنافسـين أو المتزاحمين، الأمر الذي قد يلحق أذى مألوفاً وغير مقصود بالغير، أما

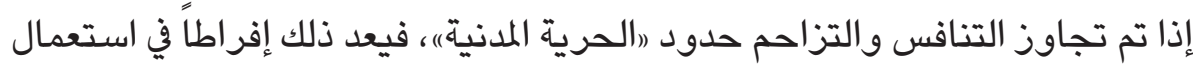

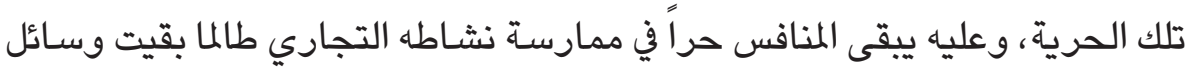

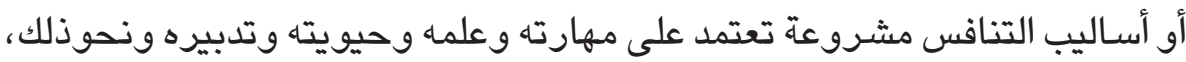

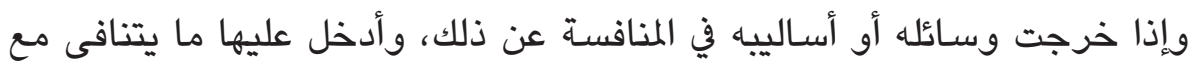

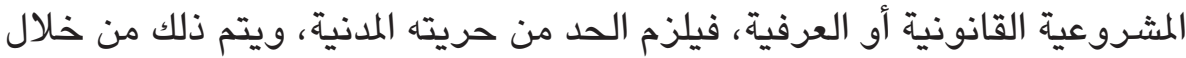

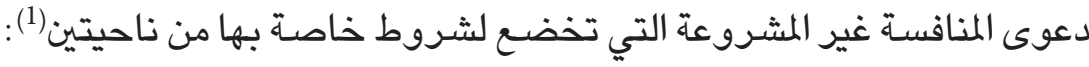
الأولى: اختلاف طريقة تقدير الخطأ في المسؤولية التقصيرية عن طريقة تقديره

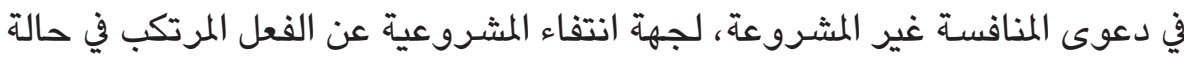

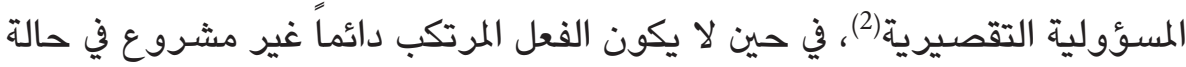

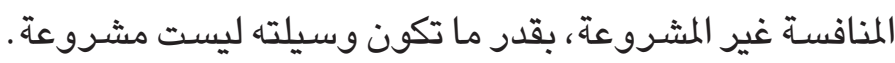

الثانيتة: اختلاف النتائج المنشودة في المسؤولية التقصيرية عنها في دعوى المنافسـة

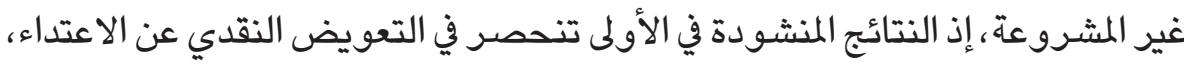

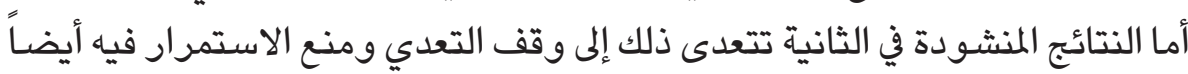

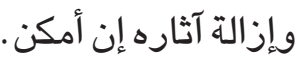

ويؤخذ على هذا الرأي رغم وجاهته، أن تحديد مسألة رالإفراط في استعمال الحرية

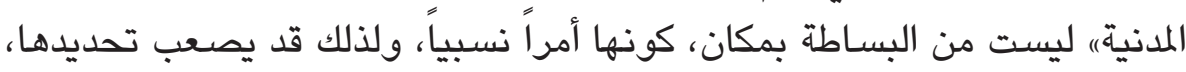

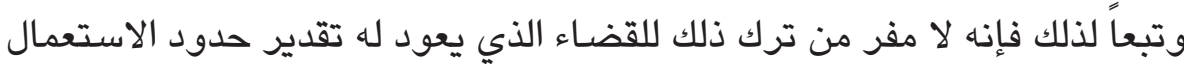

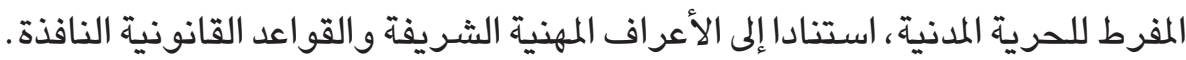

\section{الرأي الخامس- يرى أن دعوى المنافسة غير المشروعة، دعوى اقتصادية}

\section{تستند إلى (الطابع الجماعي لا الفردي)؛:}

يقوم هذا الرأي على فكرة تنطلق من أن دعوى المنافسة غير المشروعة لم تعد

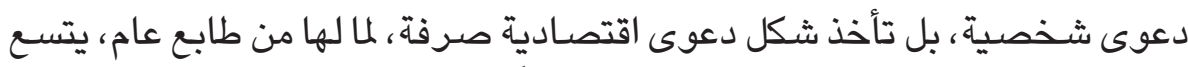

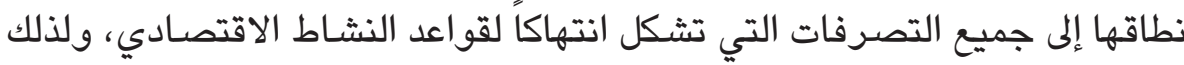

$$
\text { (1) د. جوزيف نخلة سماحة، المرجع السابق، ص129 ـ ـ د. لويس فوجال، المرجع السابق، ص724. }
$$

(2) David Kely, Ann Holmes, Ruth Hayward, Business Law, 5th edition Cavendish

Publishing Ltd, New York, 2005. p. 233. 
أخذت تُرجح فيها فكرة العقاب والزجر على فكرة التعويض والجبر، ويلاحظ أن هذا

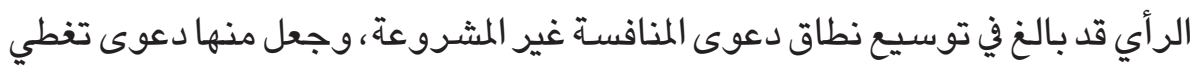

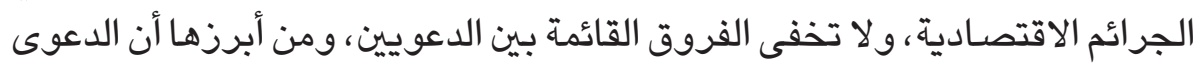

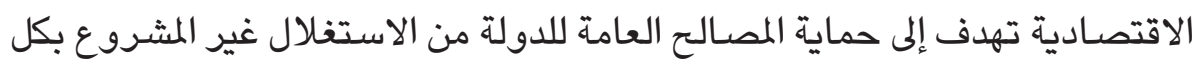

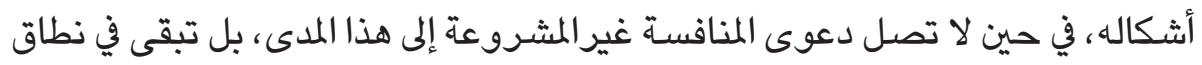

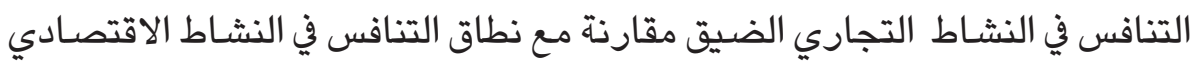

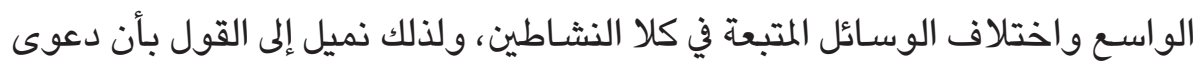

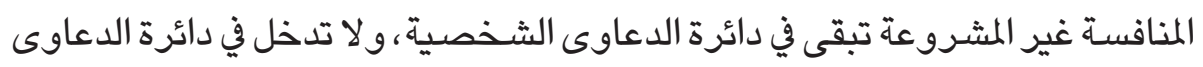

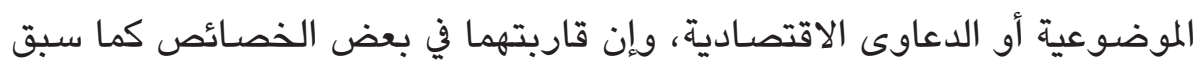
البيان.

\section{الترجيح بين الآراء السابقة:}

من الواضح أن كل رأي من الارآ المذكورة يحمل جانباً من الحقيقة القانونية

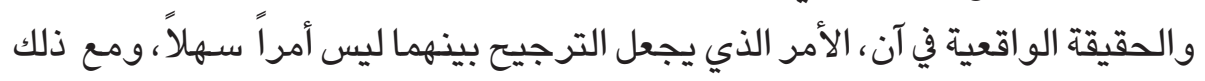

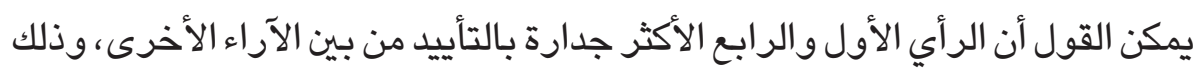
لملامستهما واتع الحال من جهة، ومقاريتهما هدف المنافس من ممارسـات المنافسة الماتسة

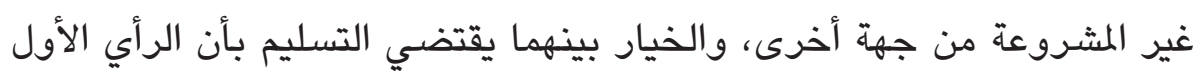

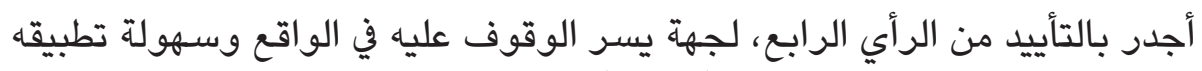

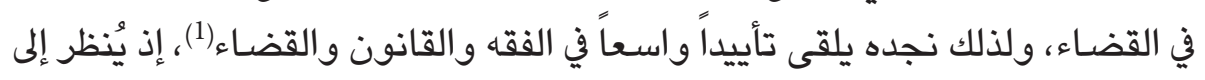

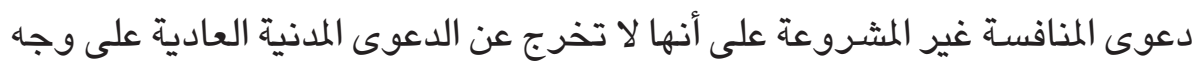

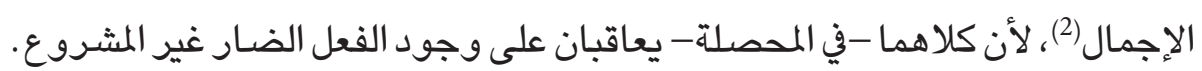

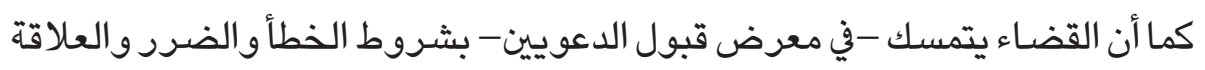

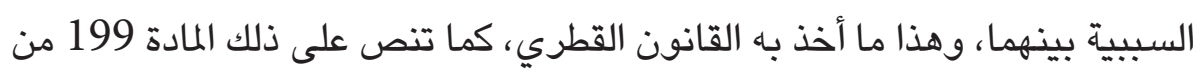

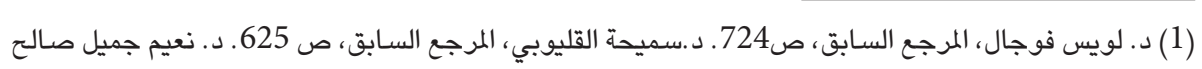

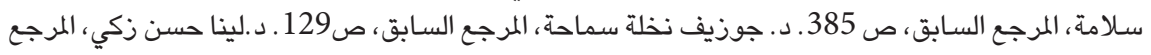

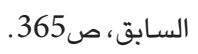

(2) وفي هذا المعنى قضت محكمة التمييز القطرية : (إن دعوى المنافسة غير المشروعة قد نشأت منذ البداية بعيدة كل البعد

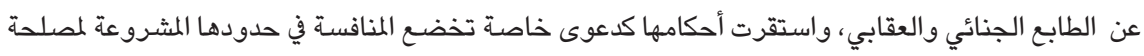

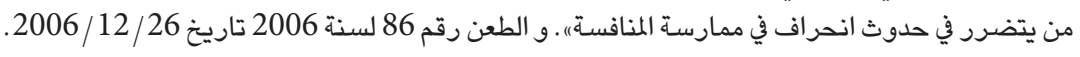


القانون المدني القطري التي جاء فيها أن : ركل خطأ سبب ضرراً للغير يلزم من ارتكبه بالتعويض)، وقدل سار على ذلك قضاء محكمة التمييز القطرية (1.). وأيا كان الأمر ، فإنه لا مفر من التسليم بوجود تداخل كبير جدا بين الدعويين

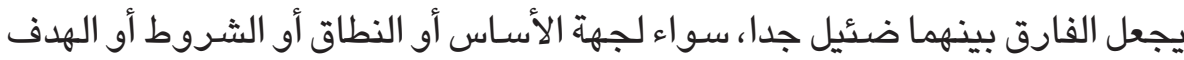

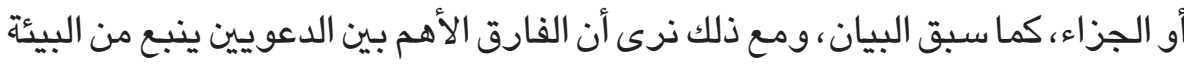

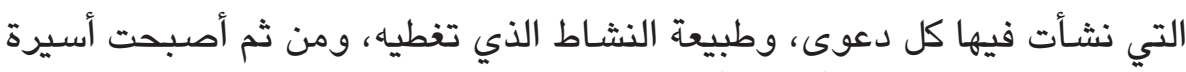
له، وتدور في فلكه وجوداً وعدماً، ذلك أن الدعوى المدنية قد نشأت فئات في بيئة مدنية،

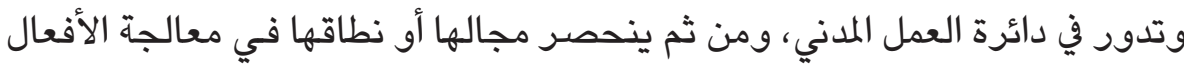

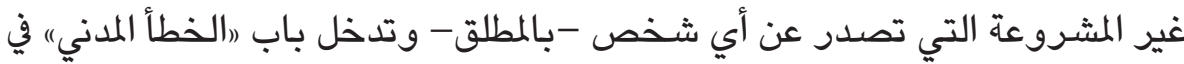

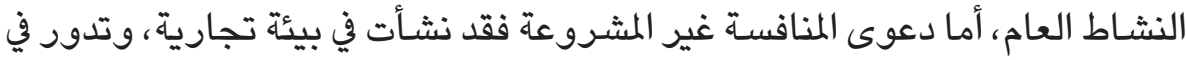

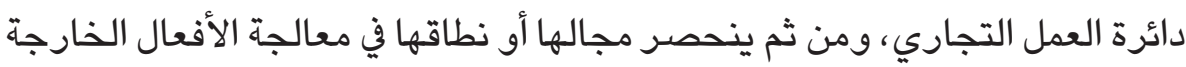
عن قواعد السوق، التي تصدر عن تجار متنافسـين -بالتحديد- وتدخل باب رالخطأ

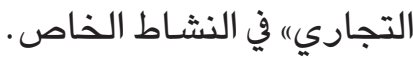

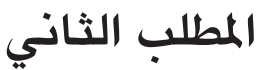

\section{شروط دعوى المنافسة غير المشسروعة}

يلزم لإقامة دعوى المنافسـة غير المشروعة توفر عدة شروط هي : وجود المنافسـة

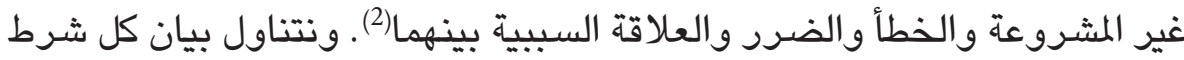
من هذه الشروط على التوالي(3):

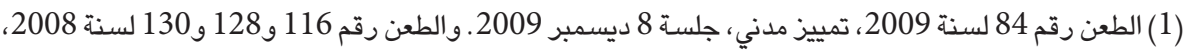

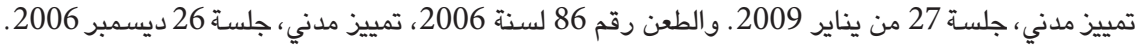

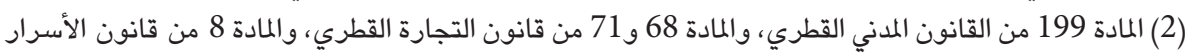
التجارية القطري.

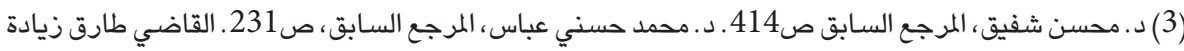

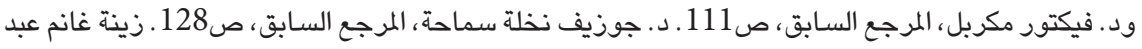

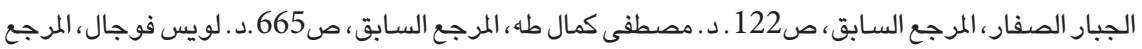

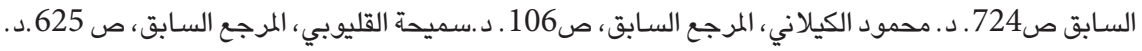

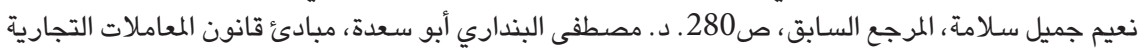

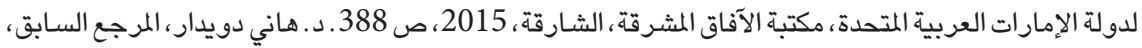




\section{أولاً - شرطوجودالمنافسة (غير المثروعة):}

تقدم القول أن المنافسة في ذاتها مشروعة، ولا يجوز حرمان أحد من حقه فيها

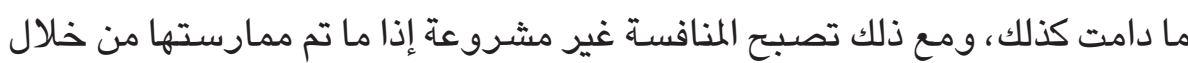

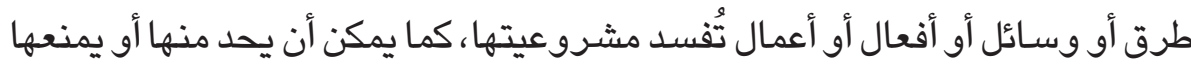

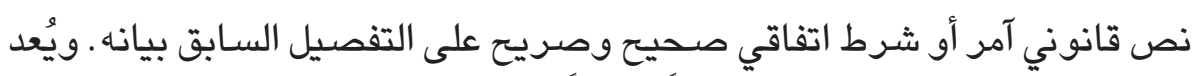

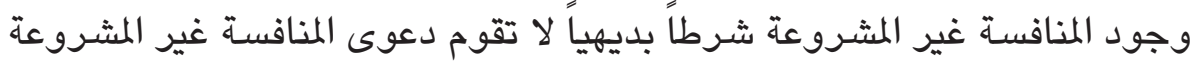

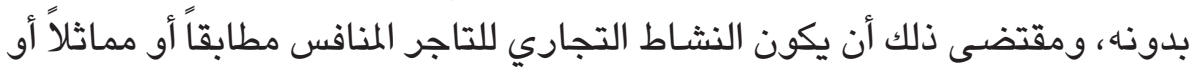

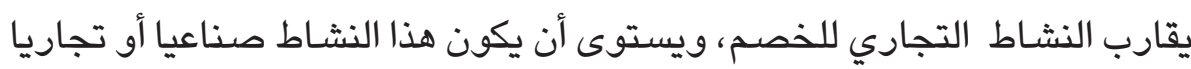
أو زر اعياً أو حرفياً أو مهنياً أو خدمياً.

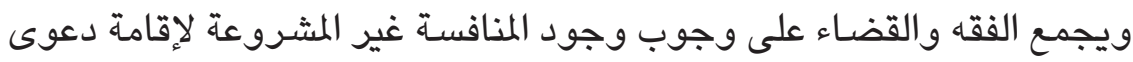

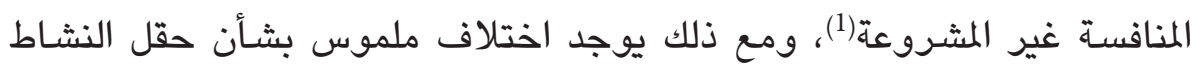

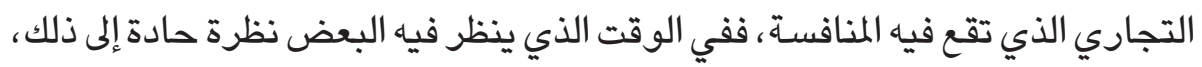

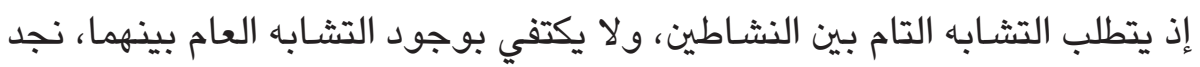

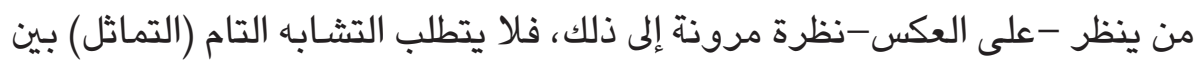

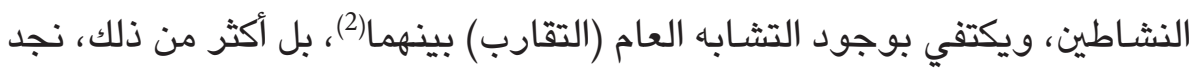

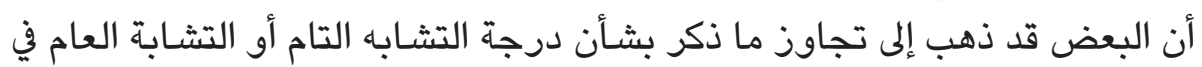

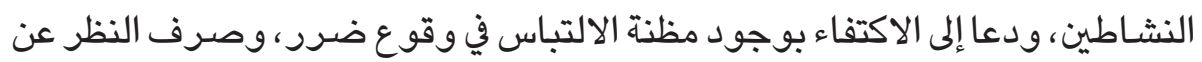

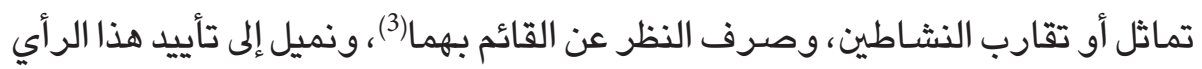
الأخير لأنه يؤدي إلى توسيع نطاق الحماية.

وقد يصعب البت في بعض حالات التشابه بين النشاطين، كأن يثور الالتباس

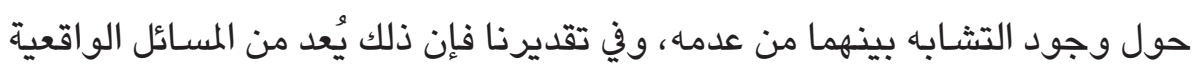

ص 221. د. عدنان أحمد ولي الغزاوي، المرجع السابق، ص309. د. د. نزال الكسواني ود. ياسين الشاذلي، المرجع

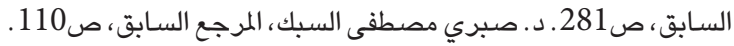

(1) المراجع المشار إليها في الهامش السابق مباشرة.

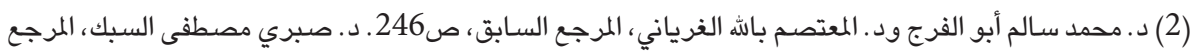

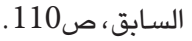
(3) د. جوزيف نظلة سماحة، المرجع السابق، ص89. د. نعيم جميل صالح سلامة، المرجع السابق، ص397. 
التي يعود لمحكمة الموضوع سلطة البت فيه، وفقاً لقناعتها الوجدانية، وإن كان لها

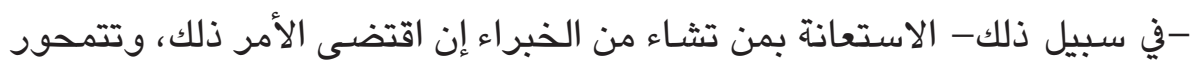

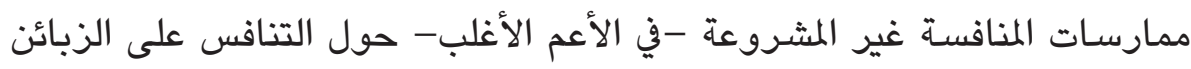

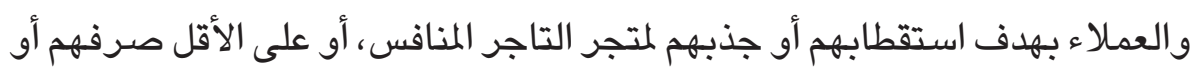

$$
\text { هجرهم للمتجر الذي يتعاملون معه. }
$$

وليس من شك أن المنافسـة غير المشروعة تنتفي في حالة أن يكون التاجران في

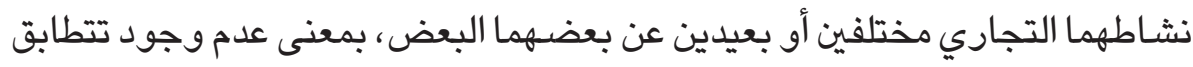

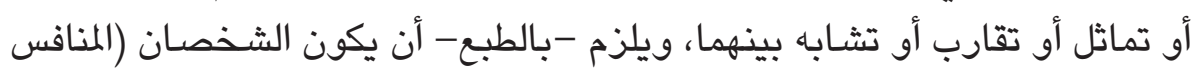

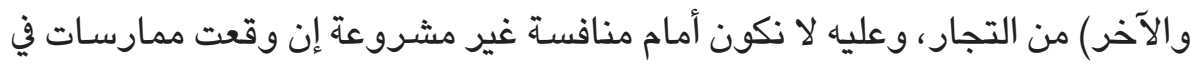

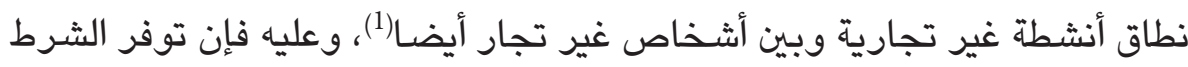

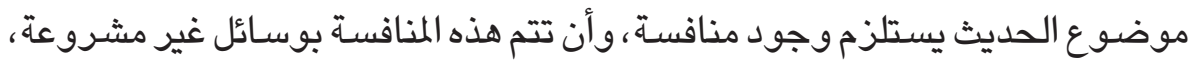

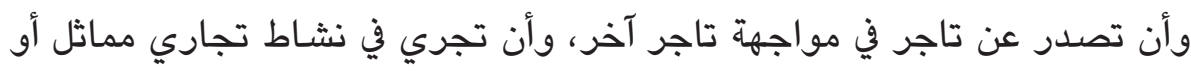

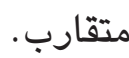

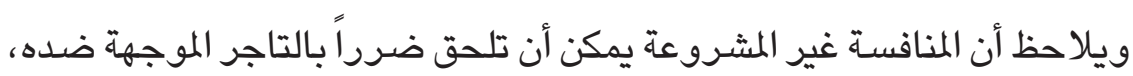

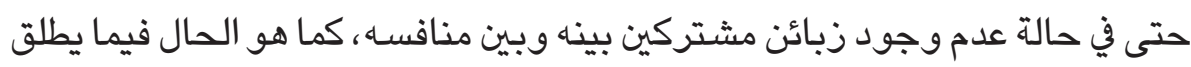

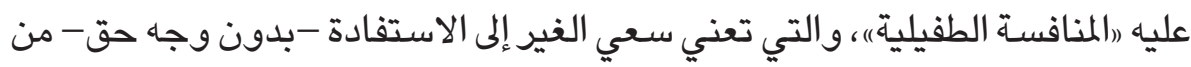

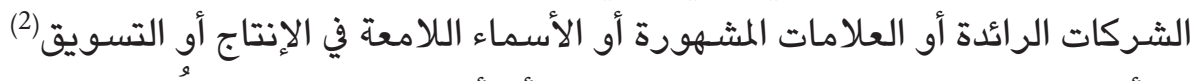

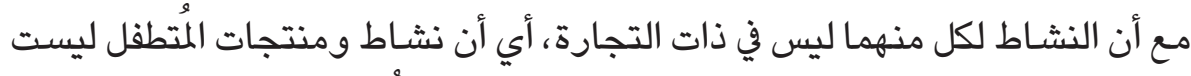

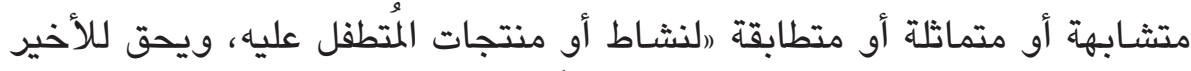

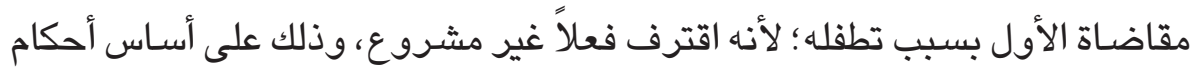

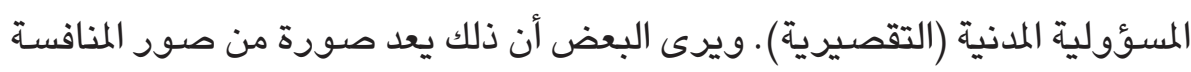

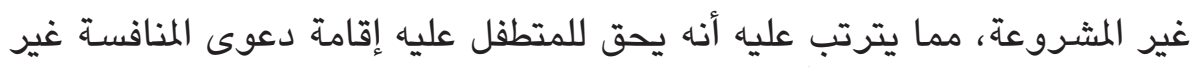

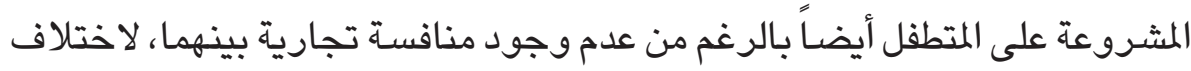

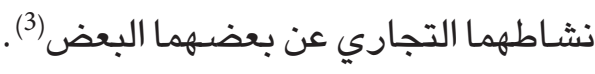
(1) د. عدنان أحمد ولي الغزاوي، المرجع السابق، ص 309 ـ د. نزال الكسواني ود . ياسين الشانلي، المرجع السابق، ص280.

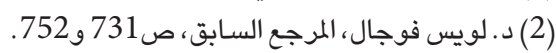

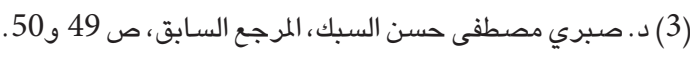




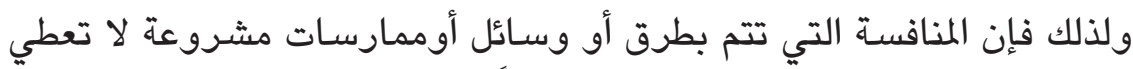

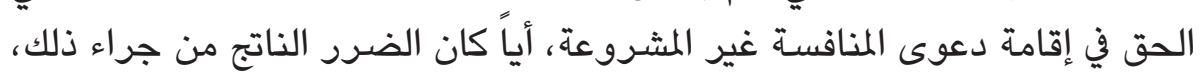

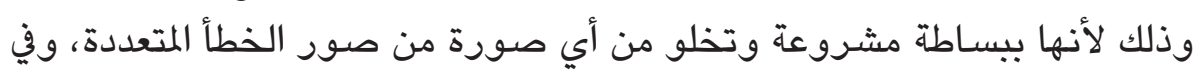

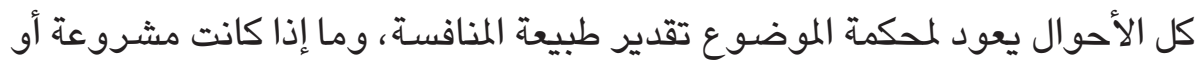

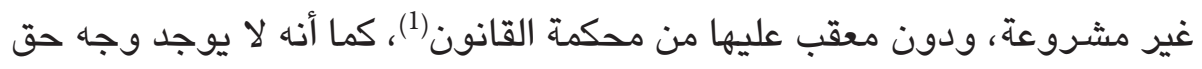

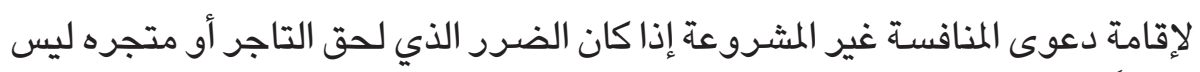

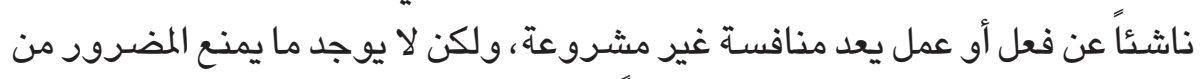

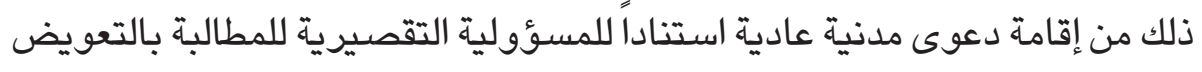
العادل متى توفرت شروط ذلك.

\section{ثانياً - شرط الخطأ:}

يقصد بالخطأ(2) في هذا المقام، انتهاك أوخروج التاجر المنافس عن صحيح القوانين والعادات والأعراف والمبادئ والقيم الدارجة في النشاط التجاري)(3)، ويأخذ الخطأ

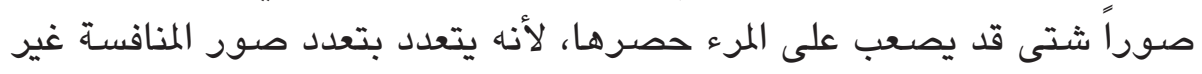

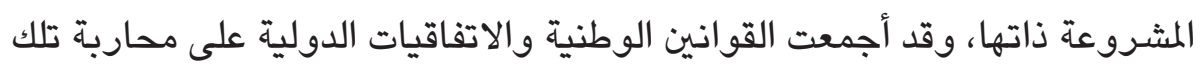

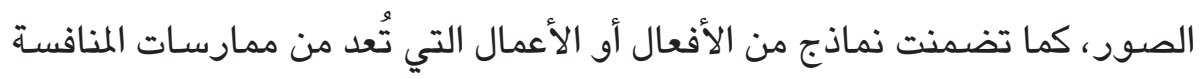

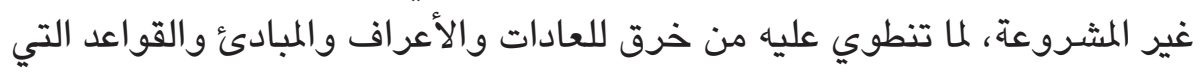

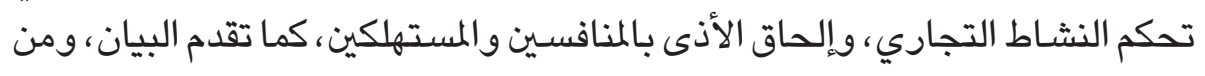

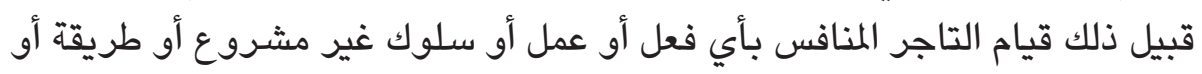

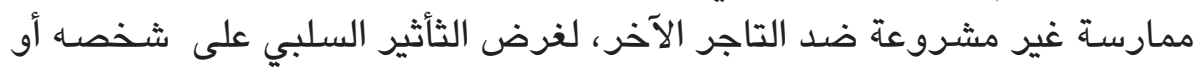

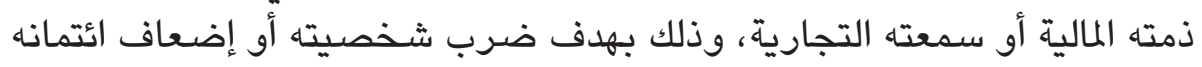

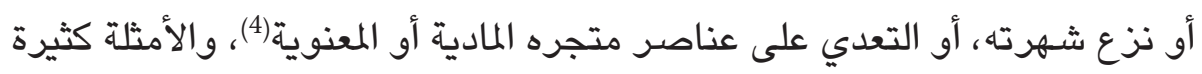

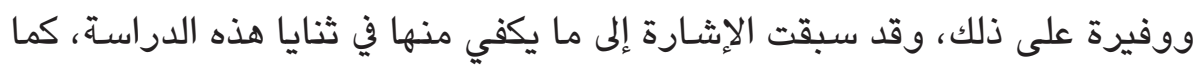

(1) د. سميحة القليوبي، المرجع السابق ، ص 635 ـ القاضي طارق زيادة ود . فيكتور مكربل، المرجع السابق، ص113

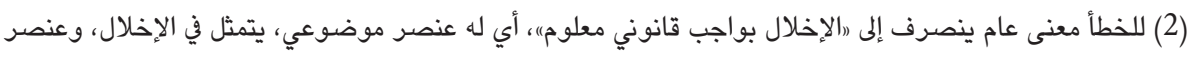

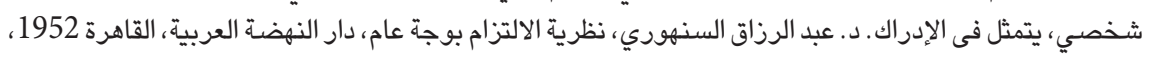

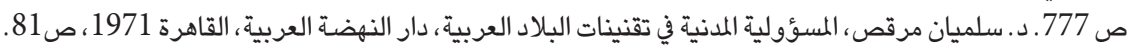

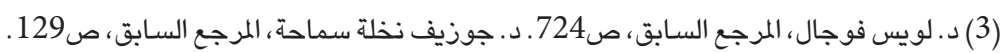

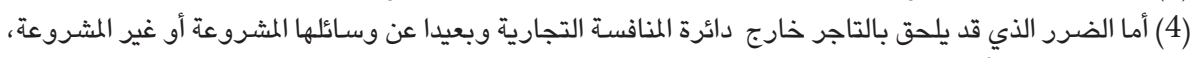

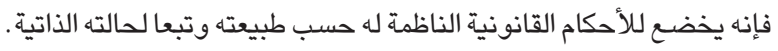




\section{يمكن القياس عليها أيضـا(1).}

ويُعد الخطأ أهم شرط من شروط دعوى المسؤولية غير المشروعة، لأنه يشكل

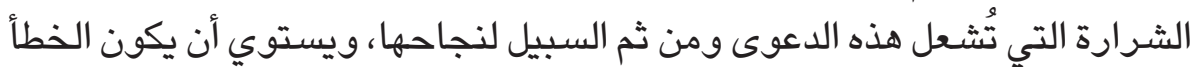

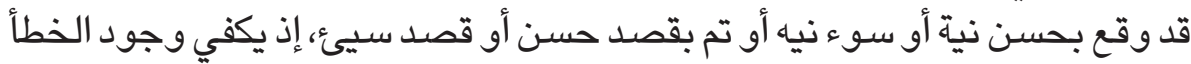

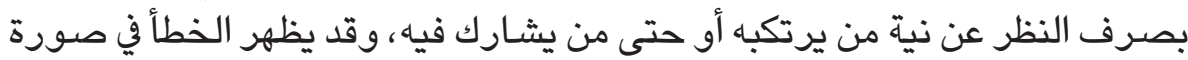

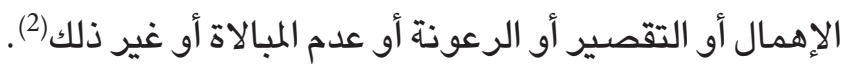

وليس من شك أن إتيان أي من الممارسات غير المشروعة المنوه عنها يُعد خطأ،

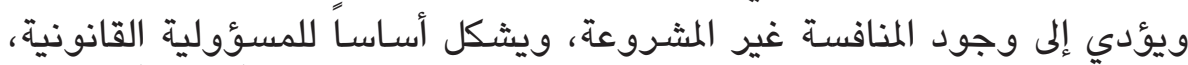

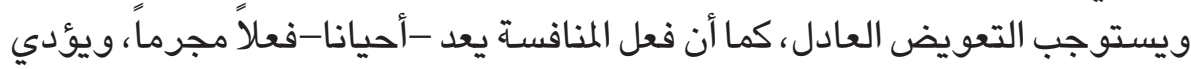

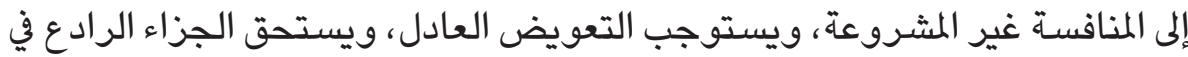

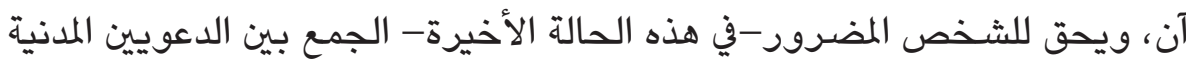

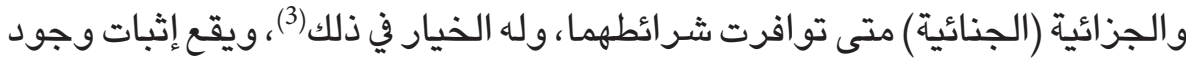

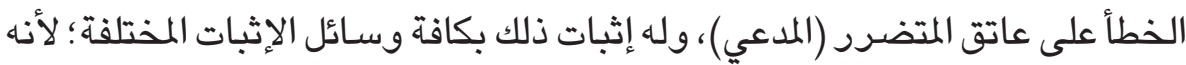

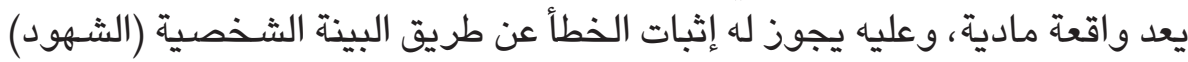

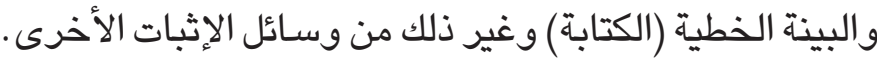

وينبغي ضرورة الملاحظة بأن التوجه التشريعي الحديث أخذ يميل إلى هجر فكرة

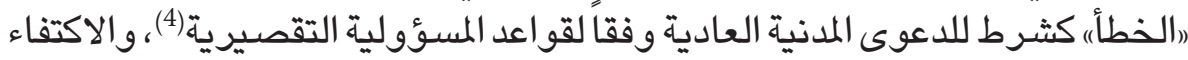

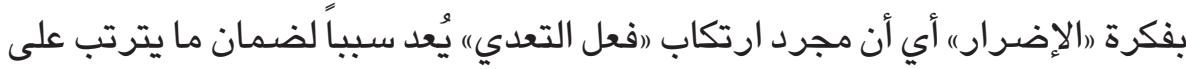

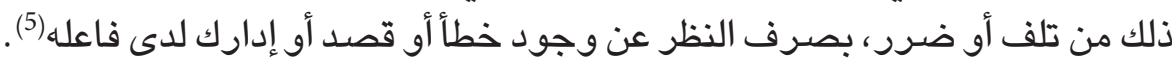

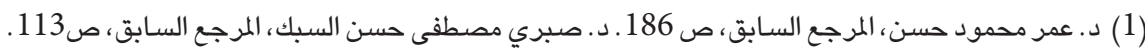

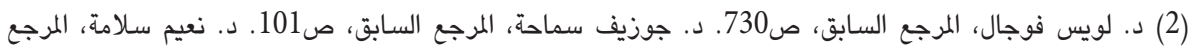

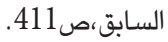

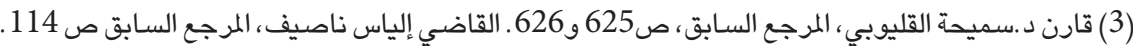

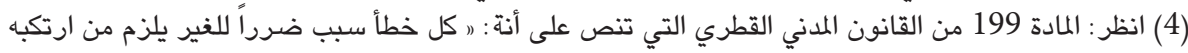

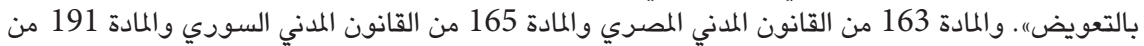

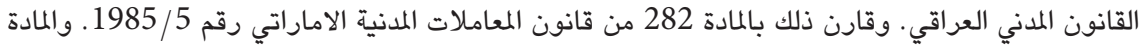
256 من القانون المدني الأردني.

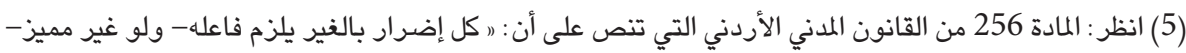

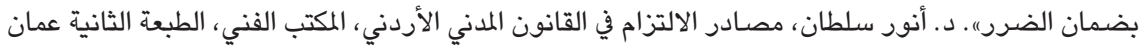

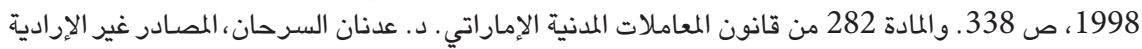

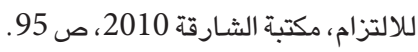




\section{ثالثاً - شرط الضرر:}

يقصد بالضرر في هذا المقام، الأذى الذي يصيب التاجر الموجه ضده ممارسات

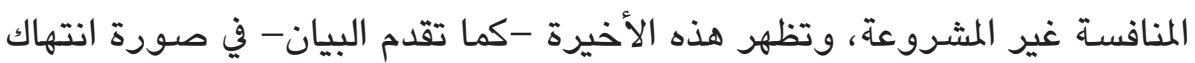

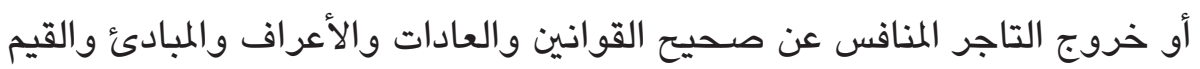

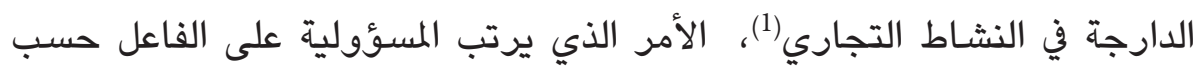

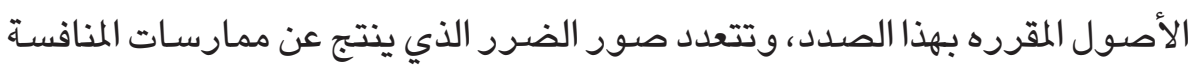

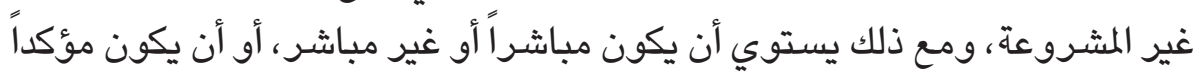

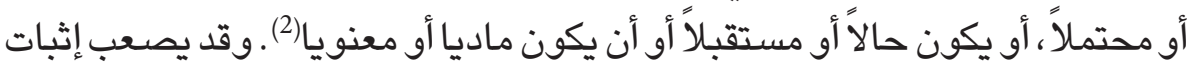

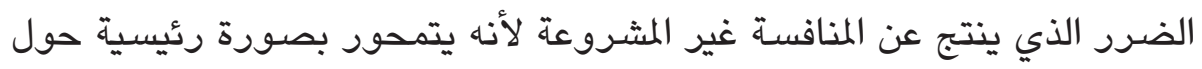

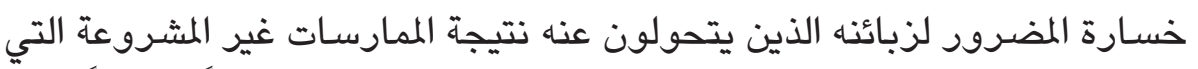

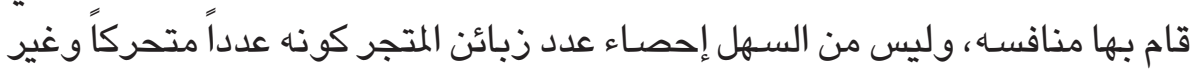

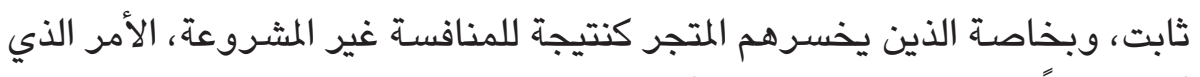

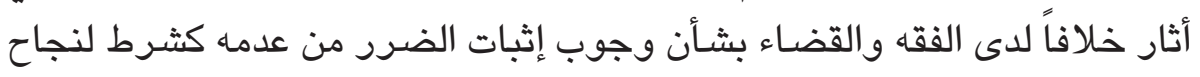

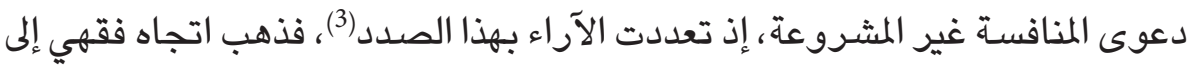
ضرورة إثبات وقوع الضرد بالمدعي حتى تتم مسؤولية المدعى عليه، وذهب اتجاه المداه فقهي آخر إلى عدم الحاجة لإثبات وقوع الضررو الاكتفاء بوقوع عات الخطأ من المدعى عليه

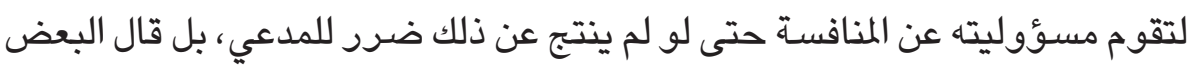

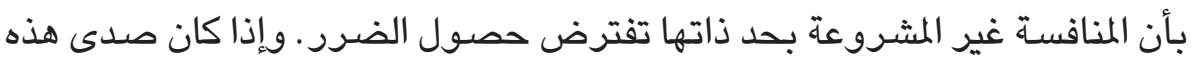

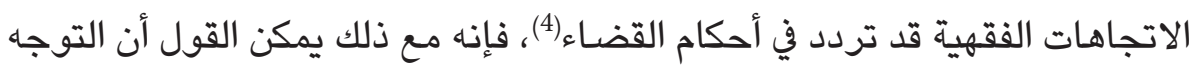

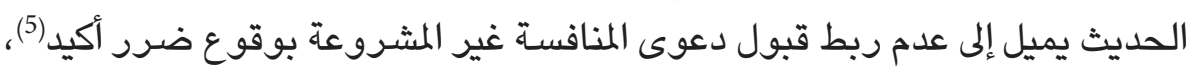

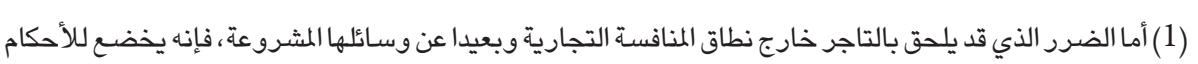

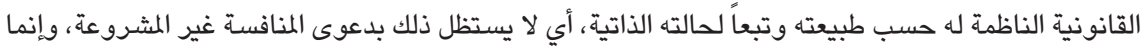

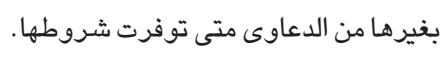

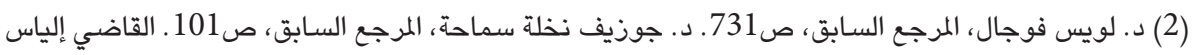

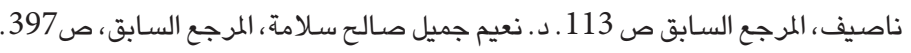

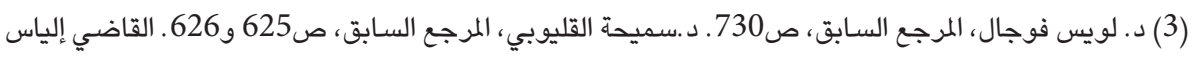

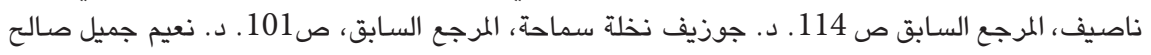

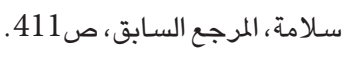

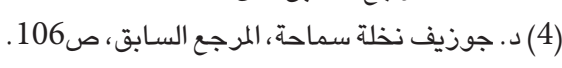

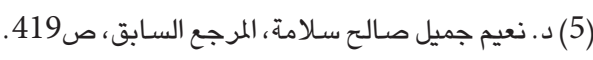


الأمر الذي يعطي للدعوى المذكورة نطاقاً واسعاً في رد وصد ممارسـات المنافسـة

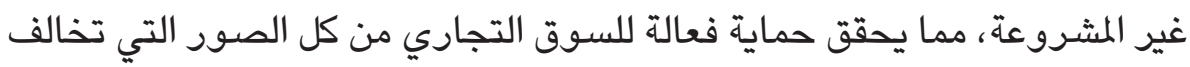
قواعده.

وتلزم الإثـارة إلى أن مسألة تقدير الضرر مسألة لست سهلة ، بل قد يصعب تقدير ذلك في حالات كثيرة، الأمر الذي قد يقتضي من المحكمة المختصة اللجوء إلى الخبرة

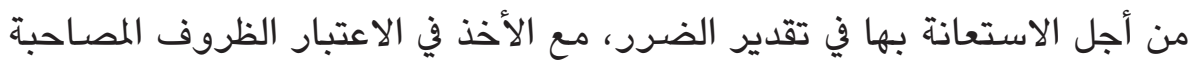

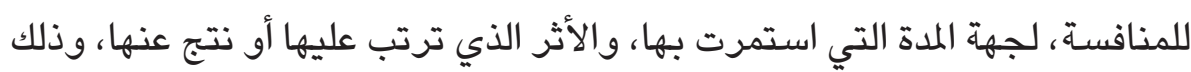

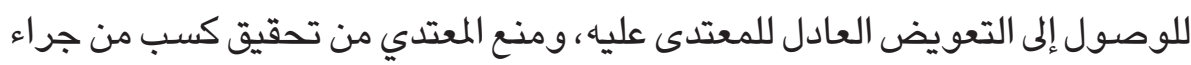

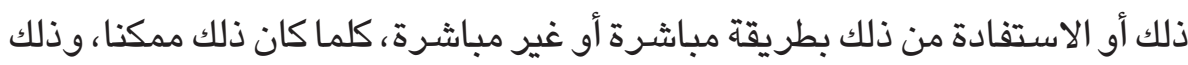

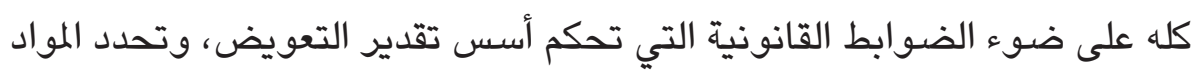
201(1) و202(2)من القانون المدني القطري تلك الأسس (3). ثالثاً - العلاقة السبيية بين الخطأ والضرر: تقدم القول أن الخطأ يعني انتهاك أو خروج التاجر المنافس لدى ممارسته نشاطه

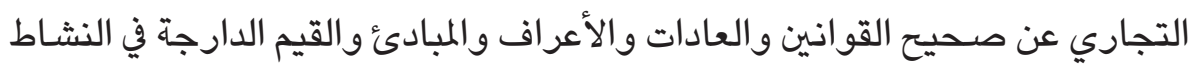

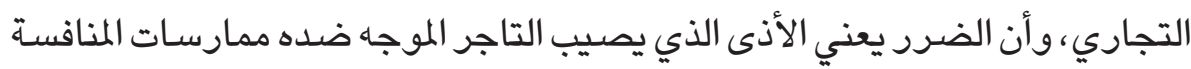

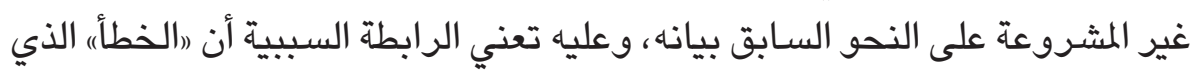

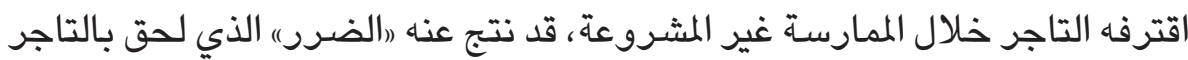

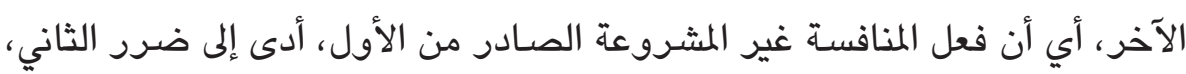

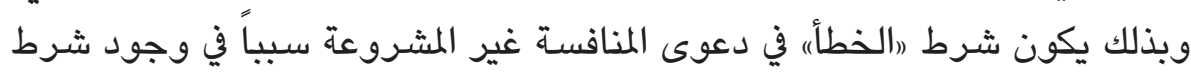
"الضرر)، أي أن هذا الأخير كان نتيجة للأول، وبذلك تنعقد الرابطة السبيية بينهما.

(1) والتي تنص على أنه : „1 - يتحدد الضرر الذي يلتزم المسؤول عن العمل غير المشروع بالتعويض عنه بالخسارة

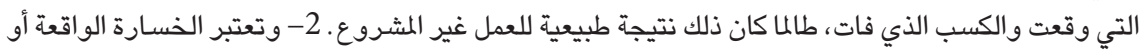

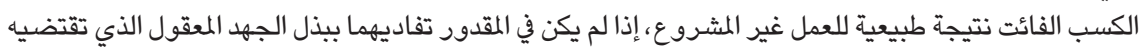

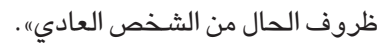
(2) والتي تنص على أنه: (يشمل التعويض عن العمل غير المشروع الضرد الضرد ولو كان أدبياً).

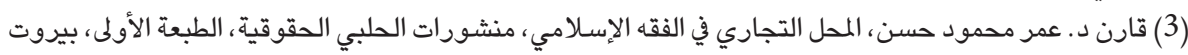
2015، صنارن د. 


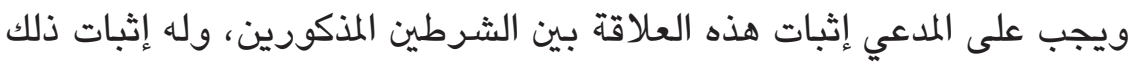

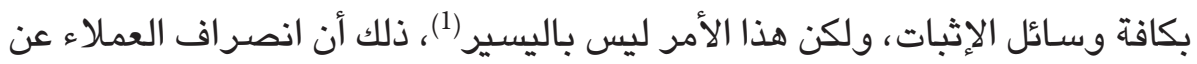

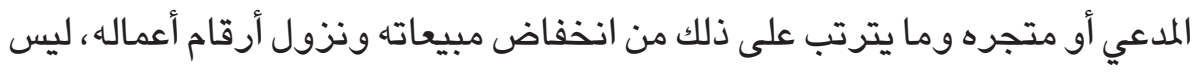

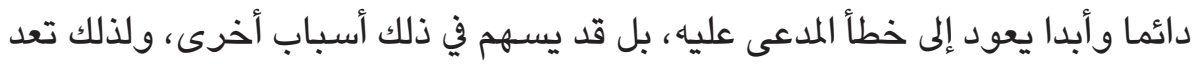

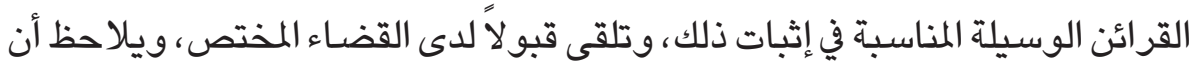

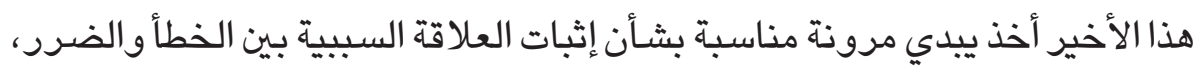

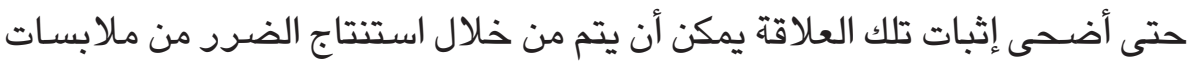

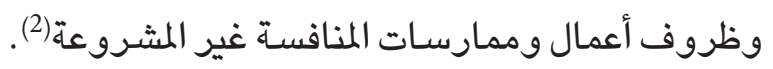

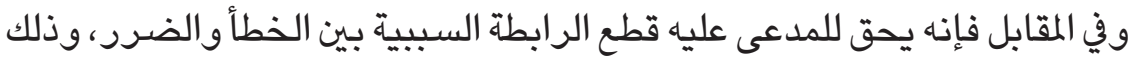

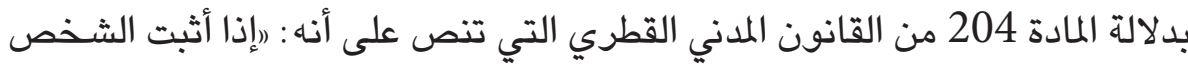

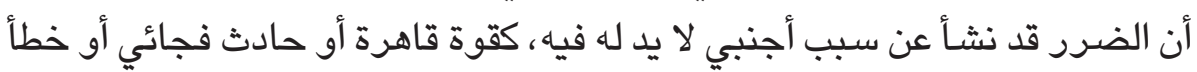

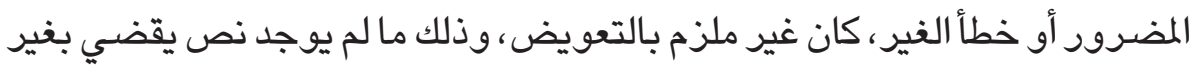

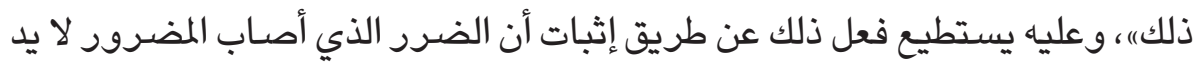

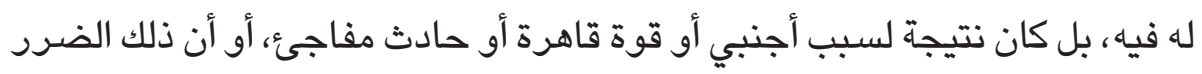

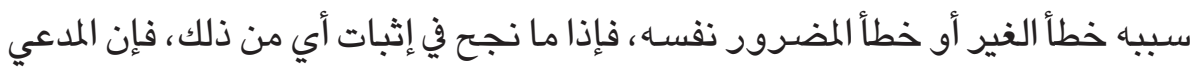

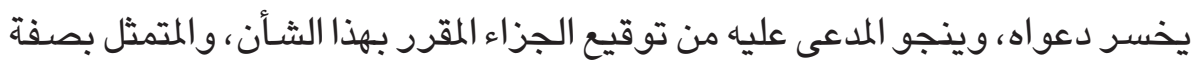

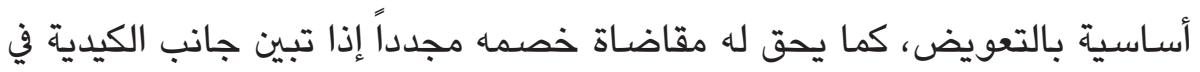

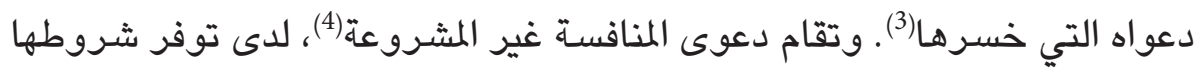

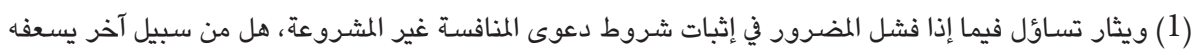

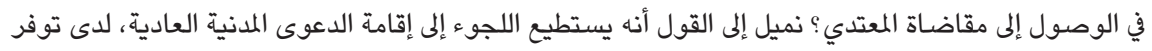

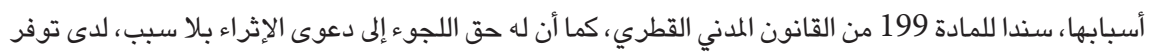

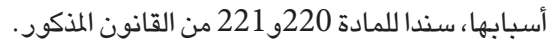

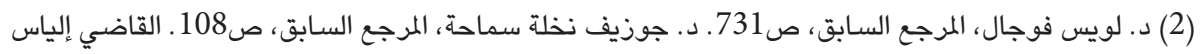

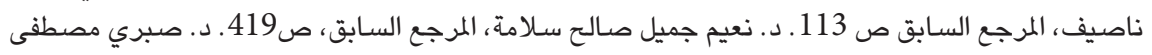

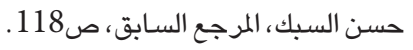

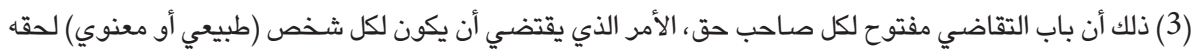

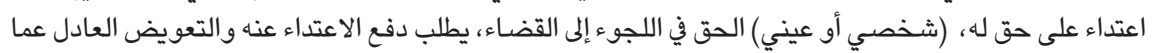

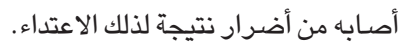

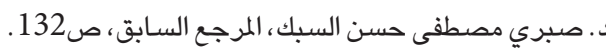


السـابق بيانها، أمام المحكمة المختصـة، والتي يتم تحديدها وفقا لقواعد الاختصـاص

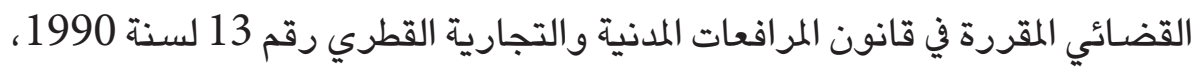
وحسب الإجراءات المقررة بهذا الصدد(1)، والخصوم في هذه الدعوى هـون هم التاجر،

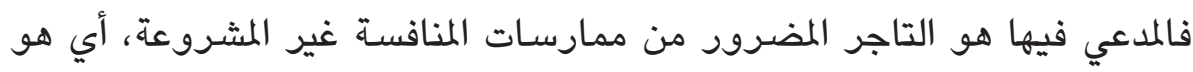

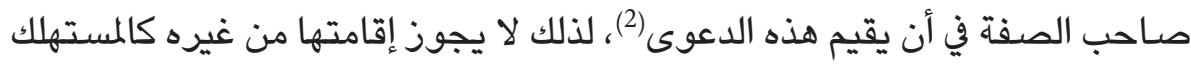

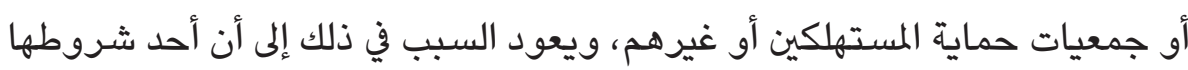

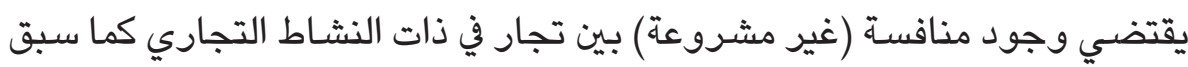

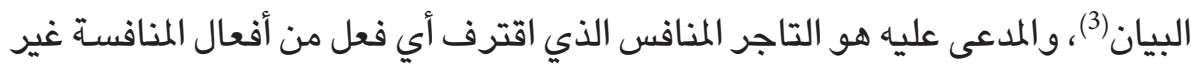

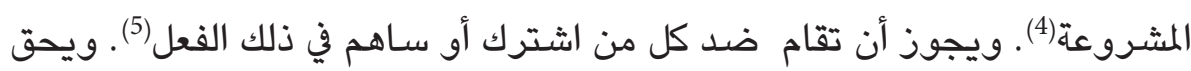

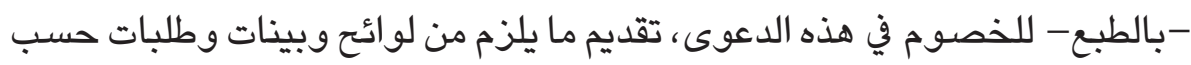
الأصول القانونية المقررة بهذ الشأن(6).

(1) المادة 22 و24 من القانون المذكور والمنشور في الجريدة الرسمية ع 13 س 30 بتاريخ 1990/9/9 1990م والمعدل

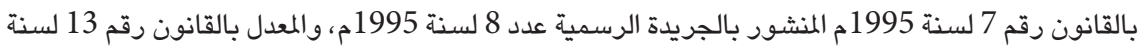

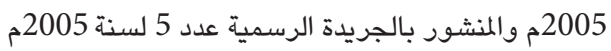

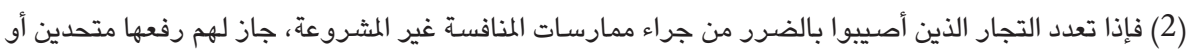
منفردين حسب واتع الحال.

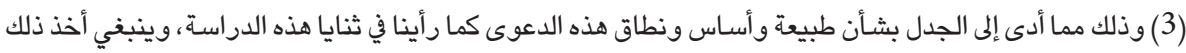

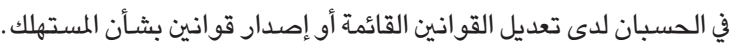

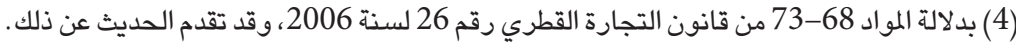

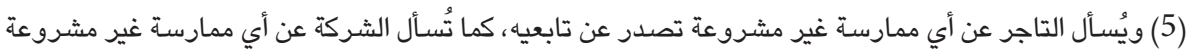
(6) المادة 1 و70 وما بعدها من قانون المرافعات المدنية والتجارية القطري رقم 13 لسنة 1990 وتعديلاته. 


\section{المطلب الثالث \\ الجزاء الذي يترتب على نجاح \\ دعوى المنافسة غير المشسروعة}

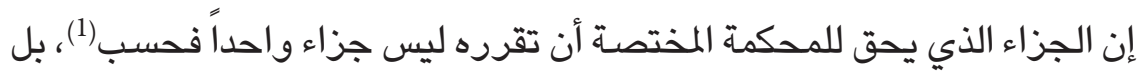

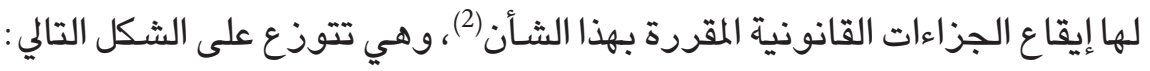
أولاً - الجزاءات المدنية:

ومن أبرز الجزاءات المدنية، التعويض العادل أو المناسب إن كان له مقتضى (3)،

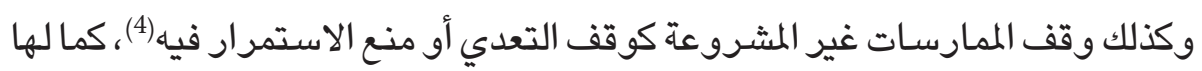

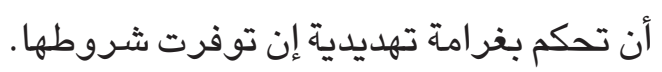
ثانياً - الجزاءات الجزائية (الجنائية):

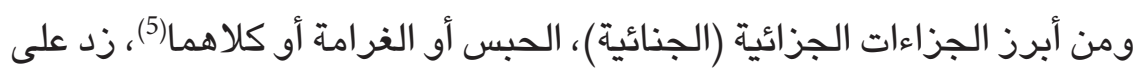

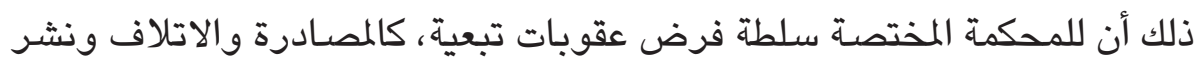
الحكم وإغلاق المتجر إن اقتضى الأمر ذلك(6).

(1) د. محمد سالم أبو الفرج ود ـ المعتصم باله الغرياني، المرجع السابق، ص250. ـ د. صبري مصطفى حسن السبك، صبك،

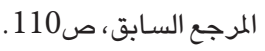

(2) وتوجد نصوص كثيرة تناولت ذلك في عدة قوانين من القوانين القطرية، سبق الإشارة إليها في ثنايا هذا البحث. انظر

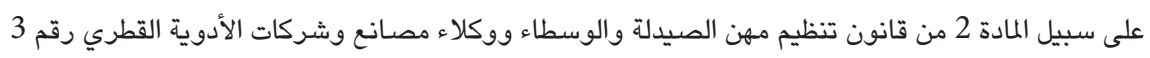

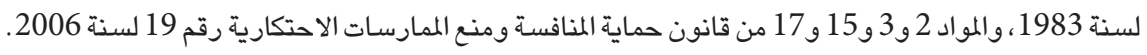

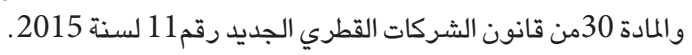

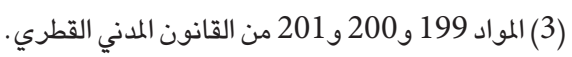

(4) والمادتان 46 و47 من القانون رقم (9) لسنة 2002 بشأن العلامات والبيانات التجارية والأسماء التجارية والمؤشرات الجغرافية والرسوم والنماذج الصناعية.

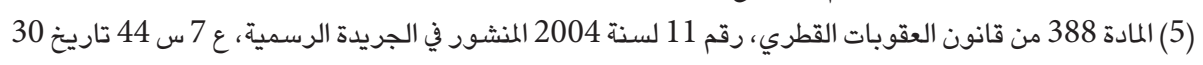

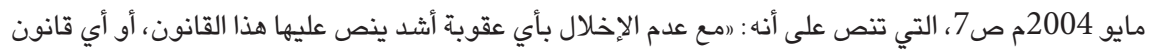

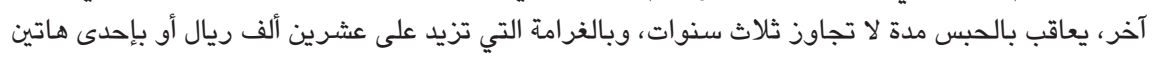

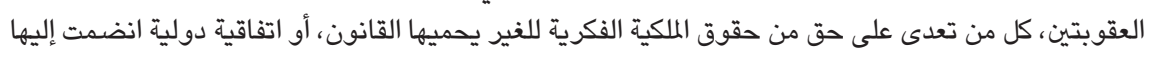

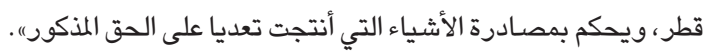

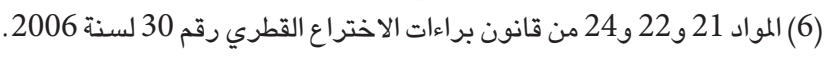


ونرى أنه من المفيد أيضـاً في هذا الصدد أن تقرر المحكمة في حدود سلطتها

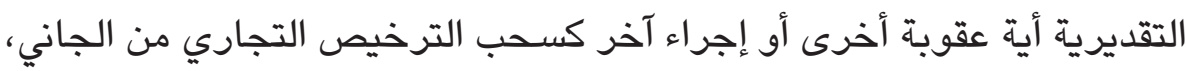

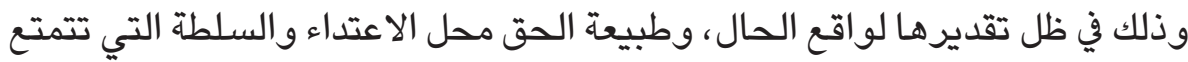
بها بموجب القانون، وتعد دعوى المنافسة غير المشروعة من الأعمال التجارية

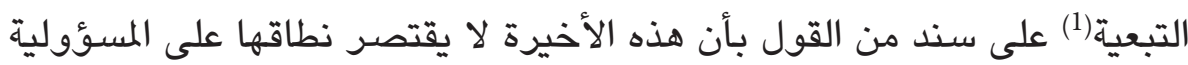

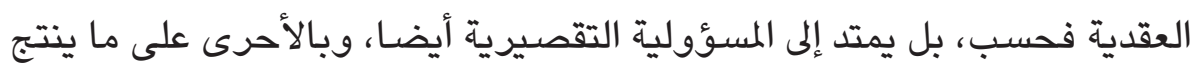

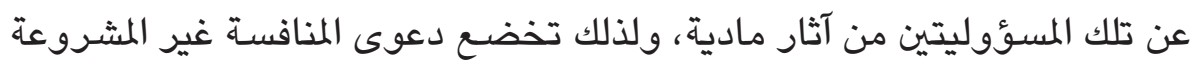
للأحكام الناظمة للتقادم التجاري (2).

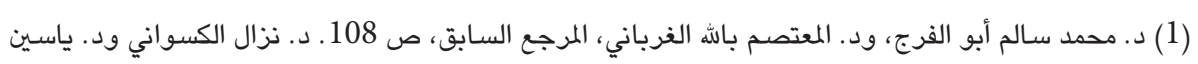

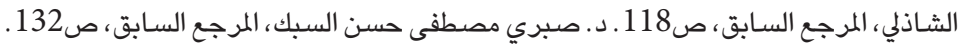

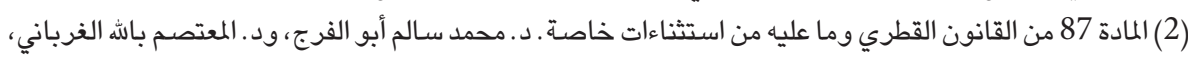

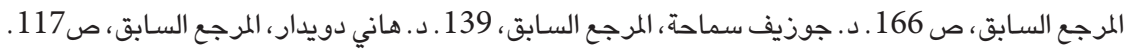




\section{الخاتمة (النتائج والتوصيات):}

\section{مما سلف، تتضح لنا النتائج الآتية:}

1 - تَعتمد دولة قطر النظام الرأسمالي (الاقتصاد الحر) منهجاً اتتصـادياً رئيسياً

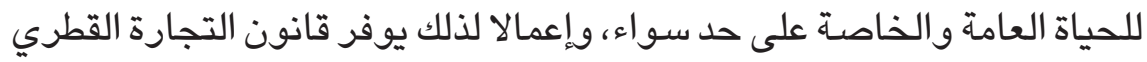

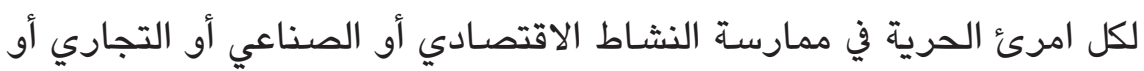
الزراعي الذي يرتئيه تحت احترام النظام العام، ومظلة القوانين السـارية في الدولة. ويالتالي يقطف كل مجتهد ثمرة اجتهاده.

2 - تُعد المنافسـة في ذاتها مشروعة، ما دامت في ظل دائرة المشروعية، وتُعد حقاً

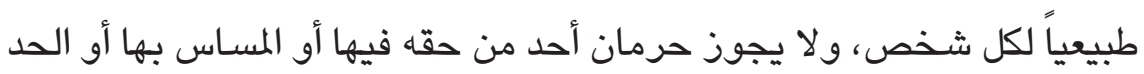

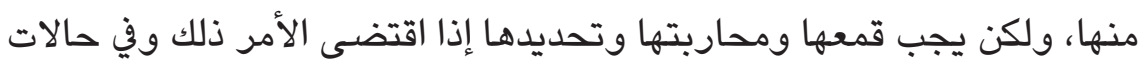

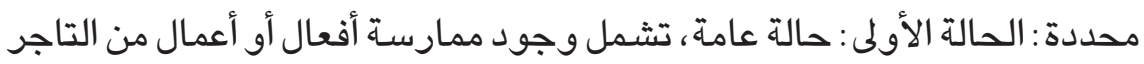

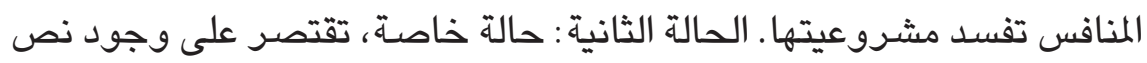
قانوني آمر يقيدها أو وجود شرط عقدي. 3 - تبقى ممارسات التاجر المنافس في دائرة المنافسة المشروعة ما دام يمارس

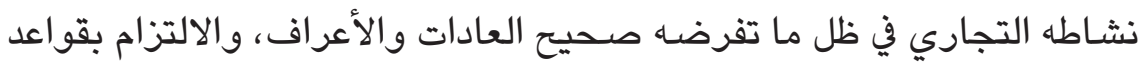

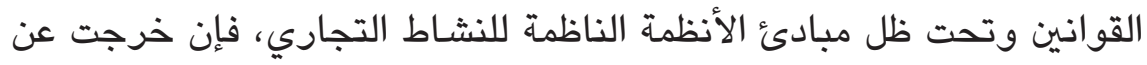
ذلك، فإنها تدخل -عندئذ- دائرة المنافسـة غير المشروعة فئه

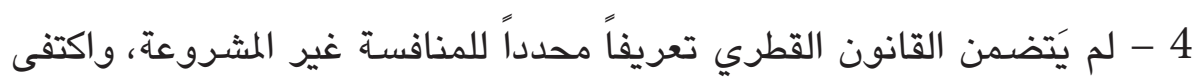

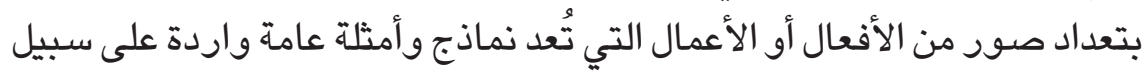

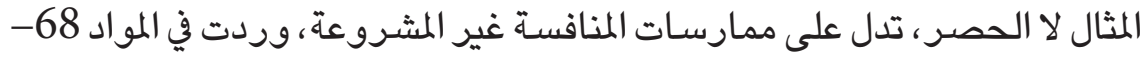

$$
73 \text { من قانون التجارة القطري رقم } 27 \text { لسنة } 2006 .
$$

5 - يُعرف قانون التجارة القطري المتجر بأنه: ارحل التاجر والحقوق المتصلة

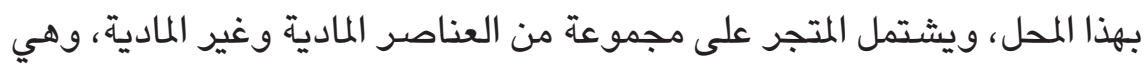

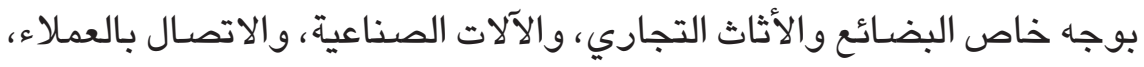

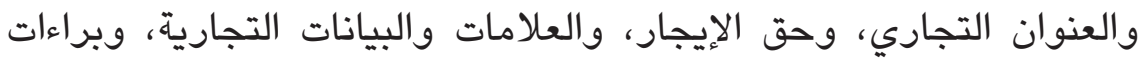




\section{الاختراع، والتراخيص، والرسوم والنماذج الصناعية)،.}

6 - يُوجد ارتباط متلازم بين دعوى المنافسة غير المشروعة وبين المتجر، (بكافة

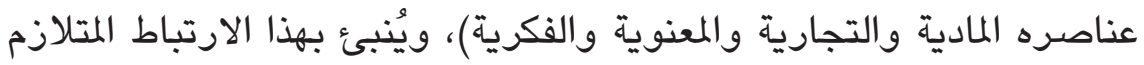

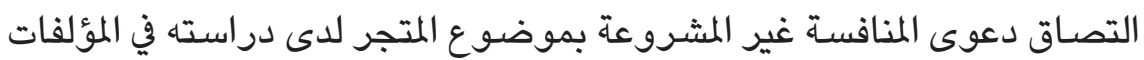

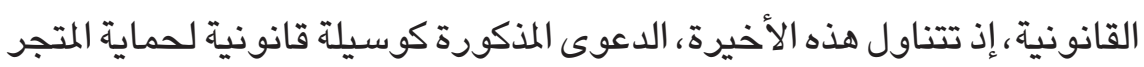
من ممارسات المنافسة غير المشروعة.

7 - يَهَف التاجر من ممارسة المنافسة غير المشروعة إلى ضرب النشاط التجاري

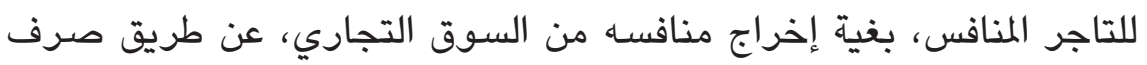

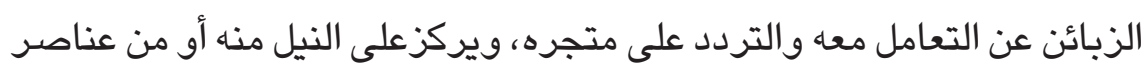

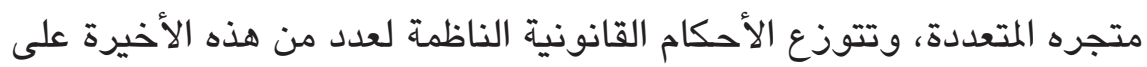

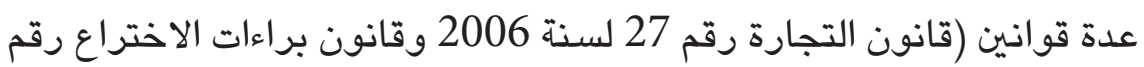
30 لسنة 2006، وقانون العلامات والبيانات التجارية والأسماء التجارية والمؤشرات الجغرافية والرسوم والنماذج الصناعية رقم (9) لسنة 2002، وقانون حماية حق المؤلف والحقوق المجاورة رقم 7 لسنة 2002).

8 - يُجمع التشريع والفقه والقضاء على محاربة كافة ممارسـات المنافسـة غير

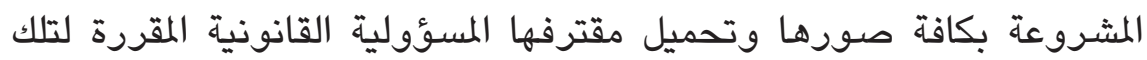
الممارسات، وتوقيع الجزاء القانوني المقرر لدى الإثبات القضـائي. 9 - يتبنى القانون القطري قاعدة (الخطأ التقصيري)" معياراً للمسؤولية المدنية عن ممارسات المنافسة غير المشروعة، بدليل منطوق المادة 199 من القدانوانون

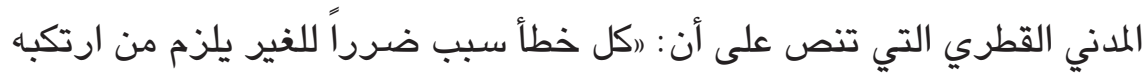
بالتعويض)، وقد سار قضاء محكمة التمييز القطرية على ذات القاعدة وذات المعيار.

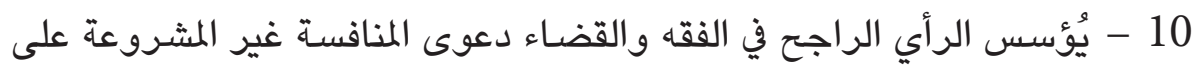

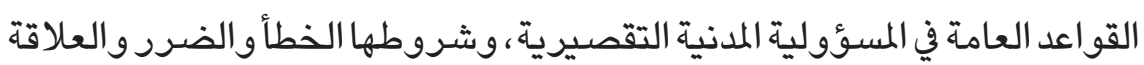
السبية بينهما، ويتبنى القانون والقضاء القطري ذلك كما تقدم القول. 
11 - جرى القضاء القطري، -لدى فصله فيما عُرض عليه من منازعات بشأن

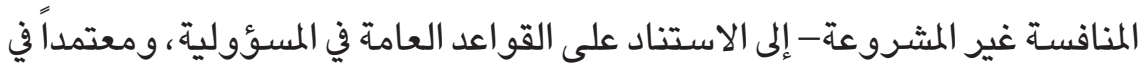
ذلك على النصوص القانونية المشار إليها.

12 - تتوزع النصوص القانونية التي تعالج ممارسات المنافسة غير المشروعة في أكثر من قانون من القوانين القطرية السارية، وتشكل أرضية مناسبة يمكن البناء

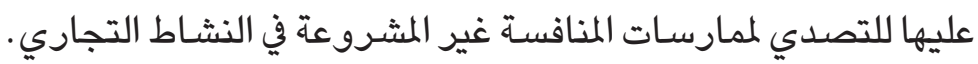
وبناءً على ما سلف، نخلص إلى التوصيات الآتية:

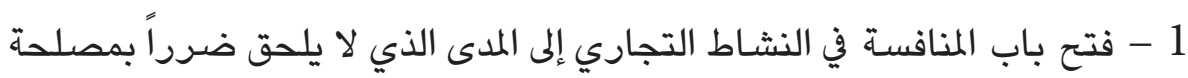
مشروعة عامة أو مصلحة مشروعة خاصة، ينص عليها القانون أو يتضمنها اتفاق.

2 - حصر المنافسة غير المشروعة في الممارسات التي "اتخرج عن العادات والتقاليد والقوانين والأنظمة الحاكمة للنشاط التجاري" على المستوى الوطني أو الدولي. 3 - تأسيس المنافسـة غير المشروعة على معيار "الإضرار بالنشـاط التجاري)، الذي ينتج عن الممارسات التي تخرج عن العادات والتقاليد والقوانين والأنظمة الحاكمة الماكية

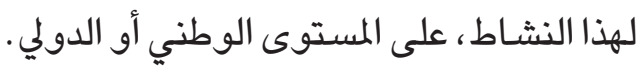
4 - اعتبار الأفعال أو الأعمال التي تشكل جرائم الذم والقدح في حال وقوعها على التى

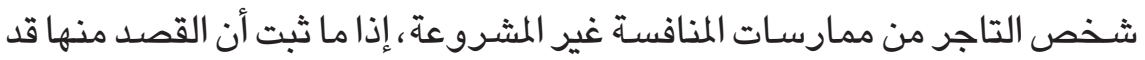

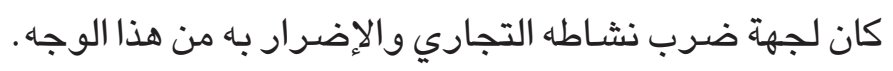
5 - هجر فكرة „الخطأ التقصيري) الذي يتبناه القانون المدني القطري في المادة 199

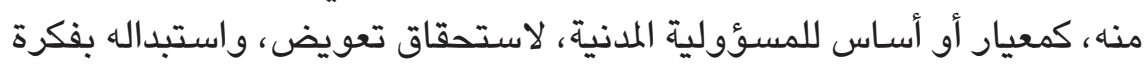

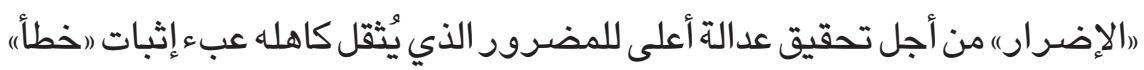

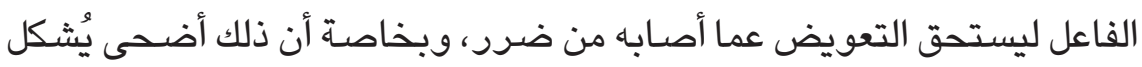

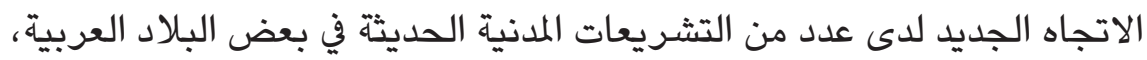

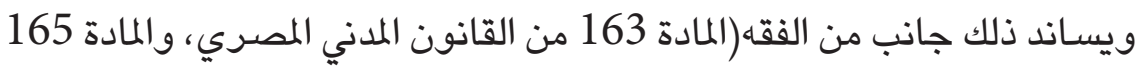

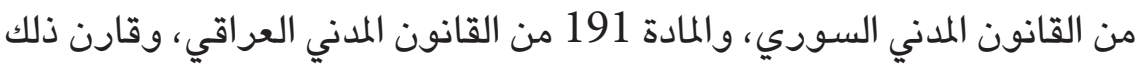


بالمادة 282 من قانون المعاملات المدنية الإماراتي، والمادة 256 من القانون المدني

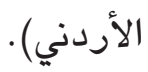

6 - تعديل نص المادة 36 من قانون التجارة القطري الخاصة بالمتجر، لأنها -من جهة- قد أغفلت ذكر عناصر أسـاسية ومهمة للمتجر، ومن قبدن قبيل ذلك الشهرة

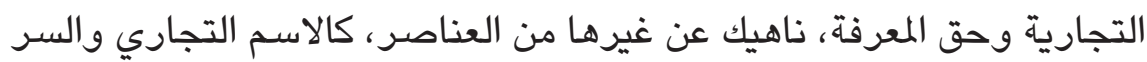

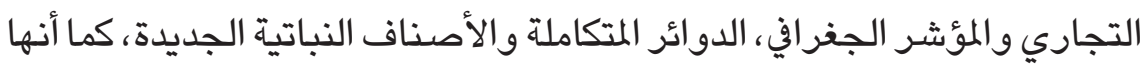

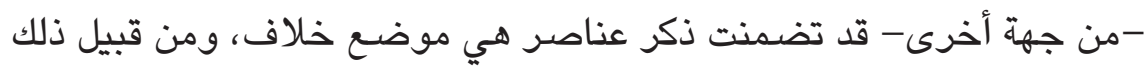

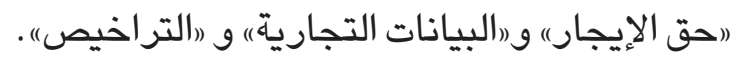

7 - عدم ربط أو قصر ممارسات المنافسة غير المشروعة بالمتجر فحسب، لأن

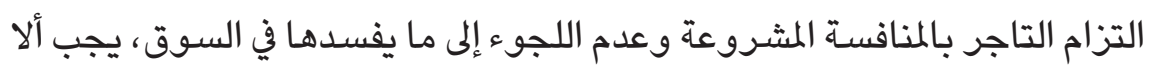

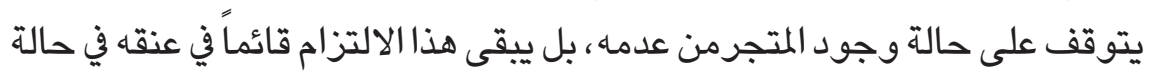

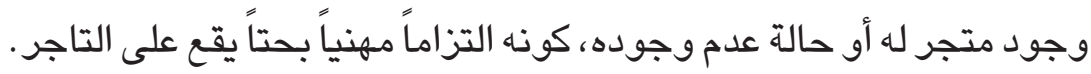

8 - إعادة النظر في صياغة المواد 68 -73 من قانون التجارة القطري، لرفع ما فيها من عيوب صياغة وقصور بشأن صور المنافسة غير المشروعة ، وتضمينها فيوراً أكثر شمولية، وبخاصـة فك الربط بين الحكم بالتعويض ووجود شئ شرط (التدليس

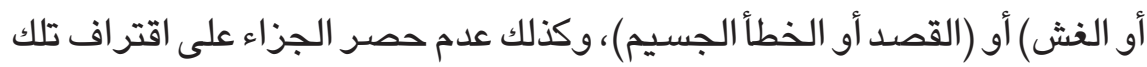

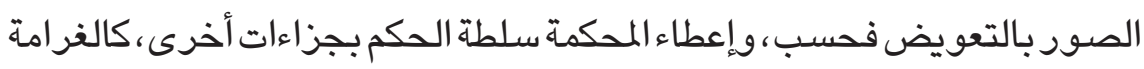
والإغلاق والنشر، وبخاصة في حالات تكرار المخالفة، فالخصـائص المتميزة التي

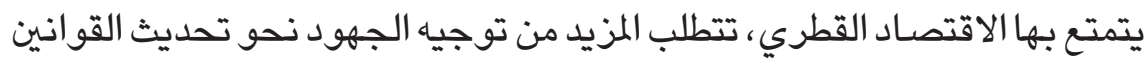

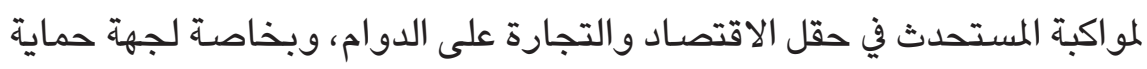

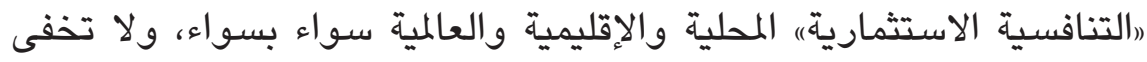

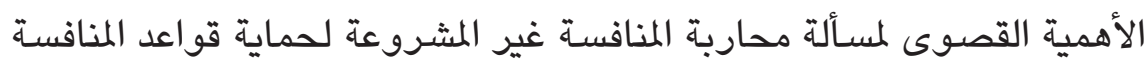
المشروعة في السوق التجارية، ويخاصسة أن التجارة في دولة قطر، تشكل عمود المدية

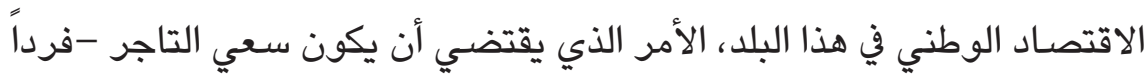

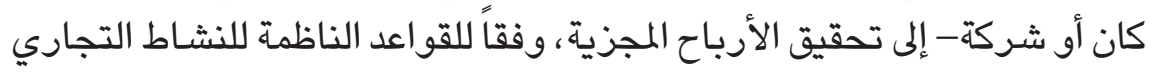


في السوق، ويؤدي إلى ضمان حق المستهلك في أن يتلقى سلعة بمواصفات جيدة

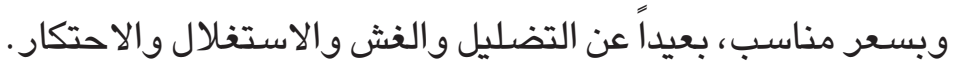

9 - إعادة النظر في القوانين الناظمة لعناصر الملكية الفكرية، وذلك بتدقيقها

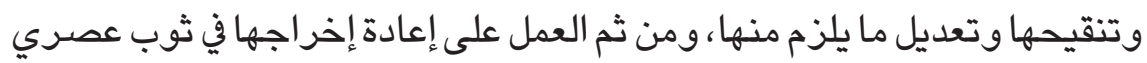

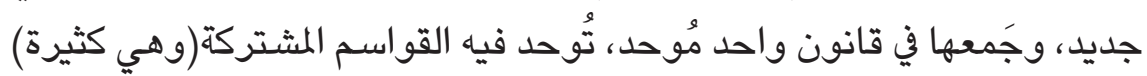
بين هذه العناصر لجهة الشكل والموضوع، ويتجاوز التكرار فيها ويزيل التزيد

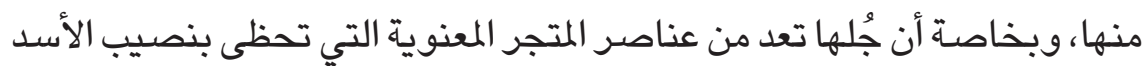

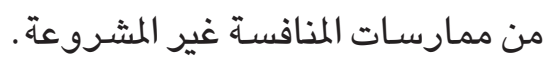

10 - توسيع نطاق دعوى المنافسـة غير المشروعة- كوسيلة حماية قانونية- لجهة تجاوز شرط وجود منافسة بين تاجرين، حتى يستظل المستهلك بمظلة الحماية

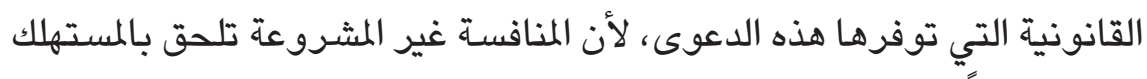

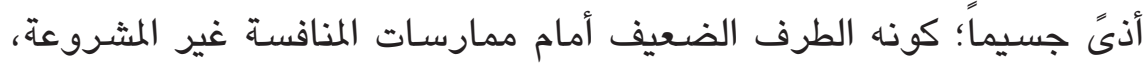
والاحتكارات التجارية والاقتصادية والسماح للمؤسسات (جمعيات حماية

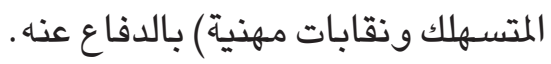

11 - سن قانون خاص بشأن محاربة وقمع المنافسـة غير المشروعة بكل أشكالها إن أمكن ذلك، من أجل تحصين السوق التجارية من ممارسـات هذه المنافسـة

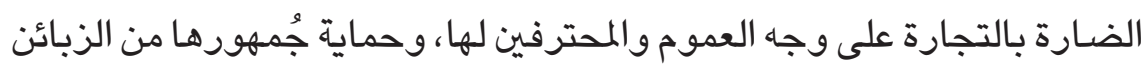

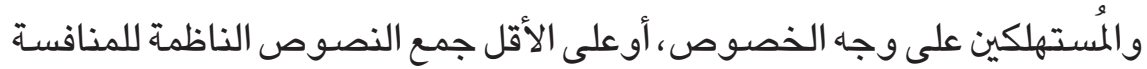
غير المشروعة، والعمل على تعديلها وتحديثها لمواكبة المستجدات في النشـاط واط الملهي

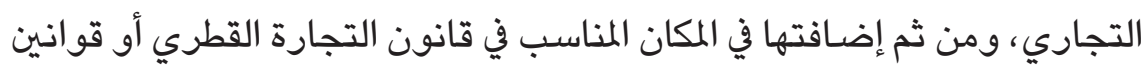
الملكية الفكرية.

12 - وأخيراً، العمل على إيجاد قضـاة متخصصين بالنظر في المنازعات التجارية ذات الصلة بالمنافسة غير المشروعة والمتجر وعناصره المعنوية، لأن الممارسات غير المشروعة تنصب عليهما بصورة مباشرة أو غير مباشرة. 


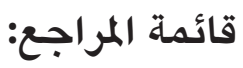

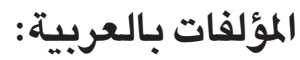

1 - أحمد حسني، قضـاء النقض التجاري، منشـأة المعارف، الإسكندرية 1981 ، مصر .

2 - أحمد سعيد شرف الدين، دراسـات في عقود التجارة الإلكترونية، مركز البحوث والدراسات بشرطة دبي، ط1، 2001، 201، الإمارات العربية المتحدة.

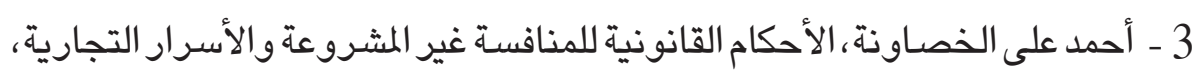

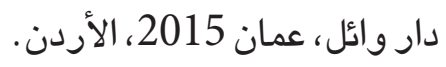

4 - أحمد محرز، الحق في المنافسة المشروعة، دار النهضـة العربية، ، القاهرة 1994، 199 مصر . 5 - أحمد مفلح خوالدة ، شرط الإعفاء من المسؤولية العقدية ، دار الثقافة للنشر الإر والتوزيع، عمان 2011، 201 الأردن.

6 - أكثم الخولي ، الموجز في القانون التجاري ، ج1، مكتبة سيد وهبة ، الإسكندرية 1970 ، مصر .

7 - السيد عطية عبد الواحد، مبادئ الاقتصاد الجزئي والكلي، مكتبة الجامعة، الشـارقة الإقة 2012، الإمارات العربية المتحدة.

8 - إلياس ناصيف، الكامل في التجارة، الجزء الأول ، عويدات للنشر والطباعة ، بيروت 1999، لبنان.

9 - ثروت علي عبدالرحيم، شرح القانون التجاري المصري الجديد ، دار النهضة

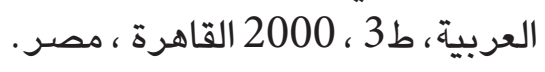

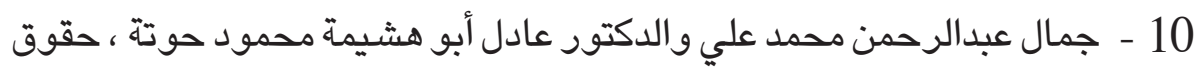
الملكية الفكرية ، دار الكتب القانونية ، الشارقة 2015، الإمارات العربية المتحدة .

11 - جوزيف نخلة سماحة، المزاحمة غير المشروعة : دراسة قانونية مقارنة، مؤسسة

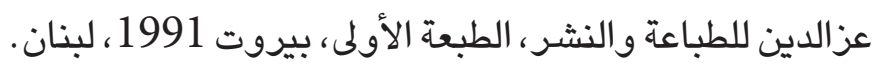

12 - جيهان حسين فقية، حماية الملكية الفكرية عبر الأقمار الصناعية، المنشورات

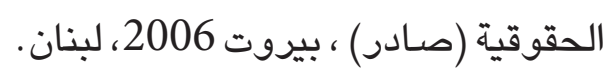


13 - حسن شفيق ، القانون التجاري، الجزء الأول ، الطبعة الأولى ، دار نشر الثقافة، الإسكندرية 1949 1949، مصر ،

14 - حسن كيرة ، الماخل إلى القانون ، الطبعة الخامسـة ، الإسكندرية 1973، مصر . 15 - حماد مصطفى عزب ، القانون التجاري السعودي ، دار النهضـة العربية ، القاهرة 2000 ، مصال مهر عزب

16 - حمد اله حمد اله، الوجيز في حقوق الملكية الصناعية والتجارية، دار النهضة العربية، القاهرة 1997 199 ، مصر.

17 - رمزي رشـاد الشيخ، الحقوق المجاورة لحق المؤلف، دار الجامعة الجديدة

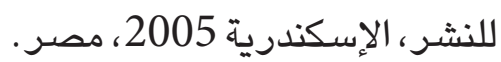

18 - زينة الصفار، المنافسة غير المشروعة للملكية الصناعية، دار الحامد للنشر والتوزيع، عمان 18 - زينة الهفار، المنافسة غين.

19 - سليمان مرقص، المسؤولية المدنية في تقنينات البلاد العربية، دار النهضة

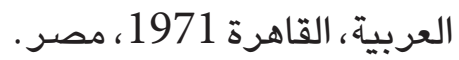

20 - سميحة القليوبي، الملكية الفكرية، ، الطبعة الرابعة، دار النهضـة العربية، القاهرة 2003، مصر .

21 - سميحة القليوبي، الوسيط في شرح قانون التجارة المصري، الجزء الأول، دار

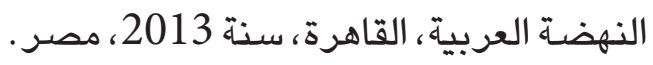

22 - سوسن سعيد شندي ، جرائم الغش التجاري ، دار النهضـة العربية ، القاهرة 2010، مصر.

23 - صبري مصطفى حسن السبك، دعوى المنافسة غير المشروعة، مكتبة الوفاء القانونية، الإسكندرية 2012 2012، مصر .

24 - صلاح زين الدين، الملكية الصناعية والتجارية، دار الثقافة، عمان 2000، الأردن. 
25 - صلاح زين الدين، حقوق الملكية الفكرية في التشريع الإماراتي والاتفاقيات الدولية، دار الفلاح، دبي 2016، الإمارات العربية المتحدة.

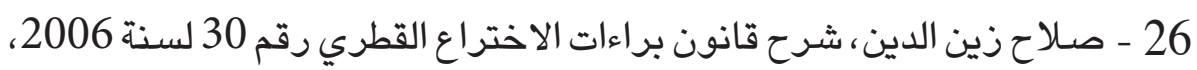
دار وائل، عمان 2010، 2010، الأردن.

27 - طارق زيادة والدكتور فيكتور مكربل، المؤسسة التجارية، دراسـة قانونية مقارنة، منشورات المكتبة الحديثة، طر ابلس، لبنان 1986.

28 - عادل إبراهيم مصطفى، الوجيز في قانون المعاملات التجارية الإماراتي ، مطبعة الفجيرة 2008، الإمارات العربية المتحدة.

29 - عبدالحق حميش، حماية المستهلك، جامعة الشـارقة، 2004، الإمارات العربية المتحدة.

30 - عبدالرحمن عبداله شمسان، الوجيز في مبادئ القانون التجاري، صنعاء 2005، اليمن.

31 - عبد الرزاق السنهوري، نظرية الالتزام بوجة عام، دار النهضـة العربية، القاهرة 1952، مصر .

32 - عبدالرشيد مأمون ومحمد سـامي عبدالصادق، حقوق المؤلف والحقوق المجاورة،

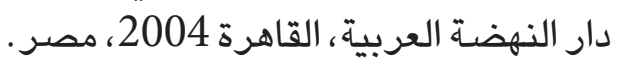

33 - عبدالفتاح بيومي حجازي، التجارة الإلكترونية وحمايتها القانونية، دار الكتب القانونية، 2007.

34 - عبدالمنعم موسى إبراهيم، حماية المستهلك، منشورات الحلبي الحقوقية، بيروت، 2007، لبنان.

35 - عدنان أحمد ولي الغزاوي، شرح قانون المعاملات التجارية الإماراتي، منشورات الحلبي الحقوقية بيروت 2009 25 لبنان الفينان.

36 - عدنان السرحان، المصادر غير الإرادية للالتزام، مكتبة الشـارقة 2010، الإمارات العربية المتحدة. 
37 - عزيز العكيلي، شرح القانون التجاري، الجزء الأول، دار الثفافة عمان1998،

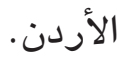

38 - علي البارودي القانون التجاري والبحري، دار المطبوعات الجامعية، الإسكندرية 1977 ، مصر البردي

39 - علي حسن يونس، المحل التجاري، دار الفكر العربي، القاهرة 1974، مصر. 40 - علي سيد قاسـ، مبادئ القانون التجاري في دولة الإمارات العربية المتحدة ، دار

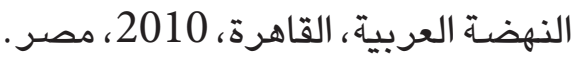

41 - عمر محمود حسن، المحل التجاري في الفقة الإسلامي، منشورات الحلبي الحقوقية ، بيروت 2015، لبنان.

42 - قدري عبدالفتاح الشهاوي، شرح قانون حماية المنافسـة ومنع الممارسـات

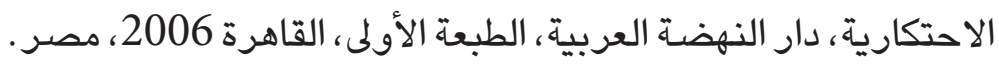
43 - كوثر سعيد عدنان خالد، حماية المستهلك الإلكتروني، دار الجامعة الجديدة، الإندا،

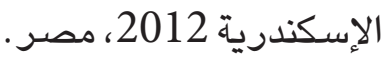

44 - لويس فوجال، المطول في القانون التجاري الفرنسي، ج.ريبير - ر. روبلو،

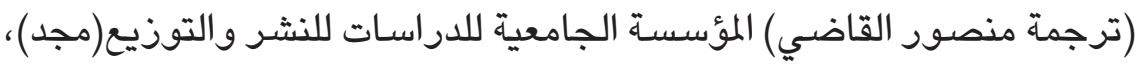
الجزء الأول، المجلد 1 ، الطبعة الأولى، بيروت المؤسة الجمعية 2007، لبنان.

45 - لينا حسن زكي، قانون حماية المنافسـة ومنع الاحتكار ، المكتبة العالمية للنشر

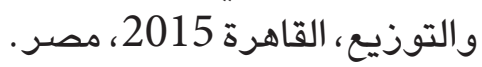

46 - محسن شفيق، القانون التجاري، الجزء الأول، الطبعة الأولى، دار نشر الثقافة

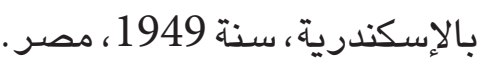

47 - محمد بهجت عبداله قايد ، القانون التجاري ، دار النهضـة العربية ، القاهرة

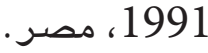

48 - محمد حسام لطفي، الإطار القانوني للمعاملات الإلكترونية، النسر الذهبي للطباعة، القاهرة 2002، مصند 
49 - محمد حسني عباس، الملكية الصناعية والمحل التجاري، دار النهضـة العربية،

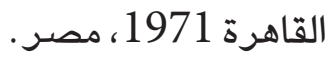

50 - محمد سالم أبو الفرج والدكتور المعتصـم باله الغرياني، القانون التجاري

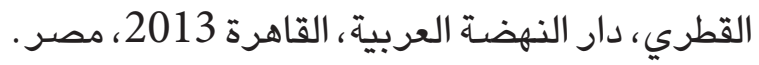

51 - محمد عبد العزيز منسى، موسوعة التحكيم منازعات التجارة الإلكترونية،

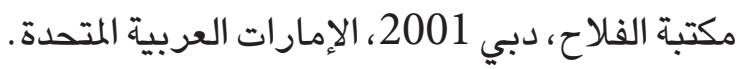

52 - محمود الكيلاني، الموسوعة التجارية والمصرفية، دار الثقافة، عمان 2011، الأردن. 53 - محمود مختار بريري، قانون المعاملات التجارية، دار النهضة العربية، القاهرة 2000، مصر.

54 - مصطفى البنداري أبو سعدة، مبادئ قانون المعاملات التجارية لدولة الإمارات

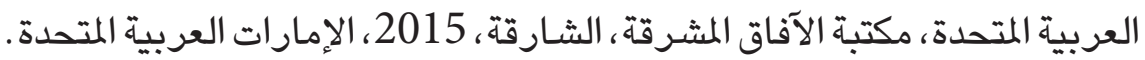
55 - مصطفى البنداري، مبادئ قانون المعاملات التجارية لدولة الإمارات العربية

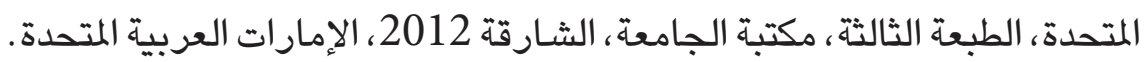
56 - مصطفى كمال طه، أصول القانون التجاري، دار الفكر العربي، الإسكندرية 2006، مصر.

57 - نزال الكسـواني والدكتور ياسـين الشـاذلي، مبادئ القانون التجاري القطري، كلية

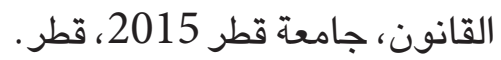

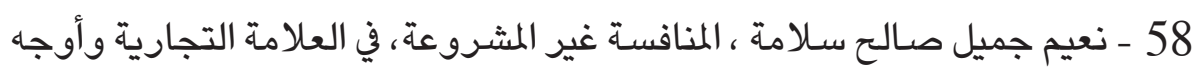

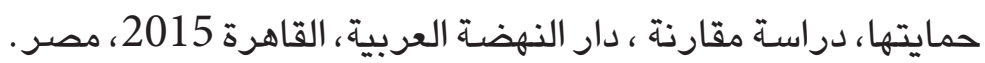
59 - هاني دويدار ، القانون التجاري، دار الجامعة الجديدة، الإسكندرية 2004، مصر. 60 - هشام فضلي، الاتجاهات الحديثة في تنظيم العقود التجارية ، دار الجامعة الجديدة، الإسكندرية - 2013، مصر، الاتهات

61 - يعقوب يوسف صرخوة، النظام القانوني للعلامات التجارية، مطبوعات جامعة الكويت، 1993 ، الكويت. 


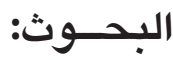

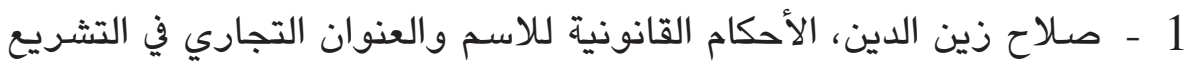

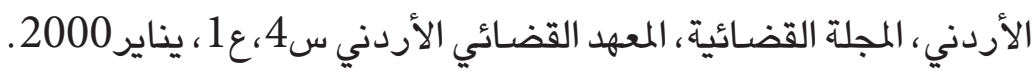

2 - صلاح زين الدين، الحماية القانونية للرسوم والنماذج الصناعية في القانون القطري،

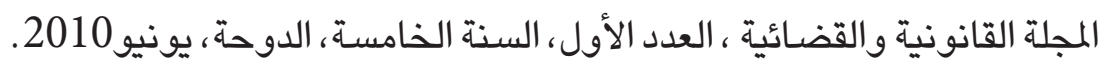

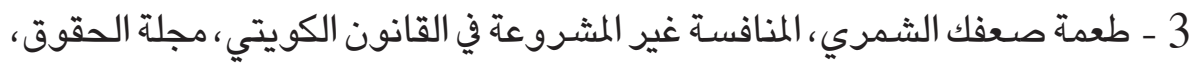

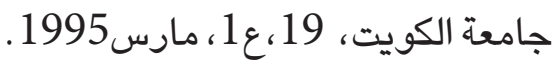

4 - عبداله خشروم، التراخيص الإجبارية لبراءات الاختراع، مجلة مؤتة للبحوث والدراسـات، المجلد 15 ، العدد4، السنة 2000.

5 - عدنان السرحان، فكرة المهني، المفهوم والانعكاسـات القانونية، كتاب وقائع مؤتمر مسؤولية المهنيين، جامعة الشارقة، النشر العلمي 35.

6 - علي نجيدة، ومضـات في القانون القطري المدني، بحث مقدم إلى مؤتمر (التقنين المدني القطري في عقده الأول، 24-23 نوفمبر 2013 كلية القانون، جامعة قطر العرد

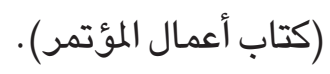

\section{القــوانـين:}

1 - قانون التجارة القطري رقم 27 لسنة 2006.

2 - قانون التجارة الكويتي (رقم 68 لسنة 1980( المعدل بالقانون رقم 13 لسنة 1996. 3 - قانون التجارة المصري رقم 17 لسنة 1999. 4 - قانون الخدمة المدنية القطري رقم (1) لسنة 2001. 5 - قانون الشركات القطري رقم 11 لسنة 2015. 6 - قانون العقويات القطري، رقم 11 لسنة 2004. 
7 - قانون العلامات والبيانات التجارية والأسماء التجارية والمؤشرات الجغرافية والرسوم والنماذج الصناعية القطري رقم (9) لسنة 2002.

8 - القانون المدني القطري رقم لسنة 2004.

9 - قانون المرافعات المدنية والتجارية القطري رقم 13 لسنة 1990 وتعديلاته. 10 - قانون براءات الاختراع القطري رقم 30 لسنة 2006.

11 - قانون تنظيم أعمال الوكلاء التجاريين القطري رقم (8) لسنة 2002.

12 - قانون تنظيم مهن الصيدلة والوسطاء ووكلاء مصانع وشركات الأدوية القطري رقم 3 لسنة 1983.

13 - قانون تنظيم ومراقبة وضـع الإعلانات القطري رقم (1) لسنة 2012. 14 - قانون حماية المنافسـة ومنع الممارسـات الاحتكارية القطري رقم 19 لسنة 2006. 15 - قانون حماية تصاميم الدوائر المتكاملة القطري رقم 6 لسنة 2005. 16 - قانون حماية حق المؤلف والحقوق المجاورة القطري رقم 7 لسنة 2002.

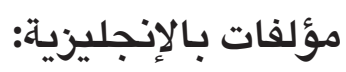

1 - Kameran Al-Salihi, Abdulla Hassan, Principles of Business Law, Alfalah Books, first Edition, Dubai, 2013, UAE.

2 - Mohamed Salem Abou El Farag, Intellectual Property Law, second edition, Dar Al Nahda Al Arabia, Cairo, 2009, Egypt.

3 - Richard Stone, The Modern Law of Contract, Seventh Edition, Routledge Cavendish, London and New York, 2008.

4 - Mosleh A. At'tarawneh, Principles of Commercial Law, Dar Qatari Bin Al-Fuja'a, Qatar, 2007. 
5 - Sylvia Kierkegaard, International Law and Trade, First edition, Ankara Barosu, Ankara, 2007, Turkey.

6 - David Kely, Ann Holmes \& Ruth Hayward, Business Law, fifth edition Cavendish Publishing Ltd, New York, 2005, USA.

7 - Mohamed El-Sayed El-Feky, Commercial Law (Commercial Operations-Merchants- Commercial Companies), Al-Halabi Legal Publications, Beirut, 2004, Lebanon.

8 - Hussam El-Ehwany, Nader Mohamed Ibrahim, Introduction to Law, an Introductory Study for Business Students, Part1 (The Theory of Law), Al Halabi Legal Publications, Beirut, 2004, Lebanon. 
المحتوى:

\begin{tabular}{|c|c|}
\hline الصفحة & 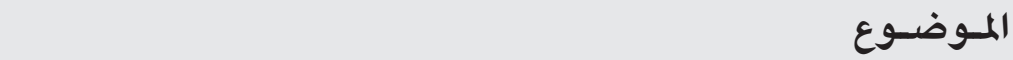 \\
\hline 57 & الملخص \\
\hline 58 & 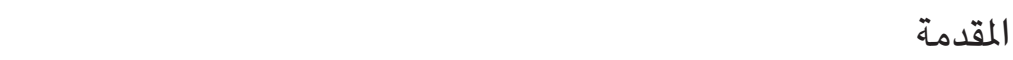 \\
\hline 64 & المبحث الأول: ماهية المنافسـة غير المشـروعة \\
\hline 64 & المطلب الأول : تعريف المنافسة غير المشروعة وتحديد معيارهـا \\
\hline 64 & الفرع الأول : تعريف المنافسـة غير المشروعة \\
\hline 74 & الفرع الثاني : معيار المنافسـة غير المشـروعة \\
\hline 81 & المطلب الثاني : تمييز المنافسـة غير المشروعة عن المنافسـة الممنوعة \\
\hline 82 & الفرع الأول : المنافسـة غير المشـروعة والمنافسـة الممنوعة بنص القانون \\
\hline 93 & الفرع الثاني : المنافسـة غير المشروعة والمنافسـة الممنوعة بمقتضـى العقد \\
\hline 104 & الفرع الثالث : مقارنة بين المنافسـة غير المشروعة وبيـن المنافسـة الممنوعة \\
\hline 108 & المبحث الثاني : صور المنافسـة غير المشـروعة \\
\hline 110 & المطلب الأول: صور المنافسة غير المشروعة التي تتضمن اعتداء على \\
\hline 110 & شخص التاجر الاول ممارسـات المنافسـة غير المشروعة التي تتضمن اعتداء على \\
\hline 112 & الذمة المالية للتاجر الثاني ممارسـات المنافسة غير المشروعة التي تتضمن اعتداءً على \\
\hline 113 & العمل في متجر الثاني: صور المنافسة غير المشروعة التي تتضمن اعتداءً على \\
\hline 114 & العمل الداخلي للمتجر الأول : ممارسـات المنافسة غير المشروعة التي تتضمن اعتداء على \\
\hline
\end{tabular}




\begin{tabular}{|c|c|}
\hline الصفحة & المــوضــوع \\
\hline 115 & العمل الخارجي الثاني : ممارستجر المنافسـة غير المشروعة التي تتضمن اعتداءً على \\
\hline 116 & عناصر متجر التاجر : صور المنافسـة غير المشروعة التي تتضمن اعتداءً على \\
\hline 117 & العناصر الأول : ممارسـات المنافسـة غير المشروعة التي تتضمن اعتداءً على \\
\hline 119 & العناصرع الثاني: صور المنافسة غير المشروعة التي تتضمن اعتداءً على \\
\hline 119 & على العناصن الأول: ممارسـات المنافسة غير التجارية للمتجر المشروعة التي تتضمن اعتداءً \\
\hline 132 & 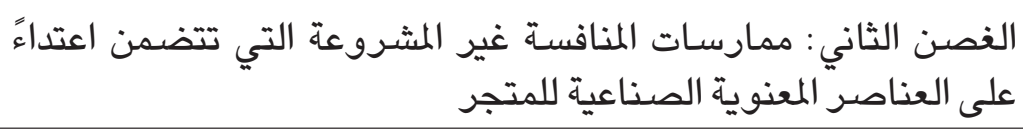 \\
\hline 139 & العناصر المعنوية الفكرية المـالثافسة غير المشروعة التي تتضمن اعتداءً على \\
\hline 144 & المبحث الثالث : دعوى المنافسـة غير المشروعة \\
\hline 144 & المطلب الأول : الأسـاس القانوني لدعوى المنافسـة غير المشروعة \\
\hline 150 & المطلب الثاني : شروط دعوى المنافسـة غير المشروعة \\
\hline 159 & المشروعة الثالث: الجزاء الذي يترتب على نجاح دعوى المنافسـة غير \\
\hline 161 & الخاتمة (النتائج والتوصيات) \\
\hline 166 & 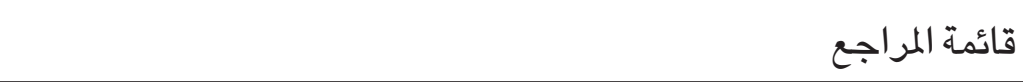 \\
\hline
\end{tabular}

